\author{
Universidade de São Paulo \\ Faculdade de Economia, Administração e Contabilidade de Ribeirão Preto \\ Departamento de Administração \\ Programa de Pós-Graduação em Administração de Organizações
}

ANA LUIZA CAMARGO MASCARIN

Interferências do ambiente institucional nas estruturas de governança de cadeias do agronegócio

Orientador: PROF. DR. MARCOS FAVA NEVES

RIBEIRÃO PRETO

2019 
Prof. Dr. Vahan Agopyan

Reitor da Universidade de São Paulo

Prof. Dr. André Lucirton Costa

Diretor da Faculdade de Administração, Economia e Contabilidade de Ribeirão Preto

Prof. Dr. Jorge Henrique Caldeira de Oliveira

Chefe do Departamento de Administração

Prof. Dr. João Luiz Passador

Coordenador do Programa de Pós-Graduação em Administração de Organizações 


\section{Interferências do ambiente institucional nas estruturas de governança de cadeias do agronegócio}

Tese apresentada ao Programa de Pós-Graduação em Administração de Organizações da Faculdade de Economia, Administração e Contabilidade de Ribeirão Preto da Universidade de São Paulo, para obtenção do título de Doutor em Ciências. Versão Corrigida. A original encontra-se disponível na FEA-RP/USP.

Orientador: PROF. DR. MARCOS FAVA NEVES

Ribeirão Preto 
Autorizo a reprodução e divulgação total ou parcial deste trabalho, por qualquer meio convencional ou eletrônico, para fins de estudo e pesquisa, desde que citada a fonte.

Catalogação da publicação

Faculdade de Economia, Administração e Contabilidade de Ribeirão Preto, Universidade de São Paulo

FICHA CATALOGRÁFICA

Mascarin, Ana Luiza Camargo

Interferências do ambiente institucional nas estruturas de governança de cadeias do agronegócio. Ribeirão Preto, 2019.

221 p.; 13 figuras; 9 gráficos; 15 quadros; 20 tabelas

Tese de doutorado, apresentada à Faculdade de Economia, Administração e Contabilidade de Ribeirão Preto/USP.

Área de concentração: Administração de Organizações.

Orientador: Marcos Fava Neves

1. Estruturas de governança. 2. Terceirização. 3. Ambiente Institucional.

4. Incerteza. 5. Sistema judiciário 


\section{FOLHA DE APROVAÇÃO}

\section{Nome: MASCARIN, Ana Luiza Camargo}

Título: Interferências do ambiente institucional nas estruturas de governança de cadeias do agronegócio

Tese apresentada ao Programa de Pós-Graduação em Administração de Organizações da Faculdade de Economia, Administração e Contabilidade de Ribeirão Preto da Universidade de São Paulo, para obtenção do título de Doutor em Ciências.

Aprovada em:

Banca Examinadora:

Prof. Dr. Marcos Fava Neves (Presidente da Banca) - Instituição: Faculdade de Economia, Administração e Contabilidade de Ribeirão Preto - FEARP/USP

Julgamento: Assinatura:

Profa. Dra. Vivian Lara dos Santos Silva Instituição: Faculdade de Zootecnica e Engenharia de Alimentos da Universidade de São Paulo (FZEA/USP)

Julgamento: Assinatura:

Prof. Gustavo Saad Diniz Instituição: Faculdade de Direito de Ribeirão Preto da Universidade de São Paulo (FDRP/USP) Julgamento: Assinatura:

Profa. Dra. Flávia Trentini Instituição: Faculdade de Direito de Ribeirão Preto da Universidade de São Paulo (FDRP/USP) Julgamento: Assinatura:

Prof. Dr. Cláudio Antonio Pinheiro Machado Filho Instituição: Faculdade de Economia, Administração e Contabilidade da Universidade de São Paulo (FEA/USP)

Julgamento: Assinatura:

Prof. Dr. Lucas Sciencia do Prado (Fundação Getúlio Vargas)

Julgamento:
Instituição: Escola de Administração de Empresas de São Paulo Assinatura: 

À minha família: os que estão sempre ao meu lado e os que deixaram saudades. 



\section{AGRADECIMENTOS}

Esse é um trabalho repleto de gratidão, tenho certeza que não conseguiria realizá-lo sozinha, durante a caminhada aprendi que "eu sou porque nós somos" do termo "ubuntu", conceito que vem de línguas faladas na África do Sul.

O primeiro agradecimento é a Deus, pela vida, pela saúde e pela fé, que me levam além.

À minha família, principalmente à minha mãe Mery, que incansavelmente se esforçou para que eu fosse o meu melhor, que ao viver os meus sonhos abriu mão de alguns de seus próprios. Ao meu pai Valdeci (in memoriam) a quem devo grande parte do amor à ciência e ao ensino.

Aos meus avós, Arthur e Cida (in memoriam) que me apoiaram incondicionalmente mesmo achando graça do fato de eu nunca parar de estudar.

Ao Yannick, pelo amor, companheirismo, paciência e apoio. Por compartilhar comigo todos os momentos, por dividir sua alegria e por ajudar a tornar o processo mais leve e mais simples, além de sonhar comigo os meus sonhos ao embarcar comigo para os Estados Unidos, durante o período de estágio internacional.

A toda a minha família e meus amigos, pelo carinho e alegrias compartilhadas e por serem apoio e ombro amigo. Quero também agradecer e dedicar essa tese aos pequenos Felipe e Gabriel, bebês muito queridos que nasceram no fim deste processo de pesquisa, eles são presentes de Deus e ajudam a renovar a esperança e a alegria. Incluo também as outras pequenas grandes alegrias da família: Gabriela, Manuela, Lara, Victor, Enzo e Pedro Augusto. Torço para que eu possa inspirá-los a se dedicarem a aprender constantemente.

Ao meu orientador, Prof. Dr. Marcos Fava Neves, por me apoiar no desenvolvimento do tema e pelo auxílio no desenvolvimento do trabalho acadêmico. Por me inspirar através de sua motivação em transmitir e disponibilizar conhecimento a tantas pessoas. Sou grata por, além de me orientar academicamente, dividir bons conselhos e ensinamentos de vida.

Ao Dr. Michael Sykuta, que me recebeu e orientou durante o período de doutorado sanduíche na Universidade do Missouri. Sua grandeza e disponibilidade em discutir e me apresentar novas teorias e pontos de vista com certeza me fizeram uma melhor pesquisadora, e contribuíram grandemente para a evolução desta tese. 

Ao Dr. Harvey James que não somente lecionou brilhantemente a disciplina Economia das Instituições e Organizações, na qual vários insights sobre a tese surgiram, como também fez questão de se certificar que estávamos bem amparados e acolher nossa família no dia de ações de graças (Thanksgiving) durante nossa estadia na Universidade do Missouri.

Ao responsável pelo meu interesse na Nova Economia Institucional, o Prof. Décio Zylbersztajn, que transformou minha vida profissional ao demonstrar sua paixão pela academia e ao me orientar durante o mestrado. Ao Prof. Evaristo Marzabel Neves, por me orientar durante a graduação em um momento de dúvidas e me incentivar posteriormente a seguir para a pós-graduação 'strictu sensu'.

Aos membros da banca de qualificação Prof. Dr. Dante Pinheiro Martinelli e Prof. Dr. Rogério Castro pelas sugestões, direcionamento e contribuições. Ao Prof. Dr. Christiano França da Cunha, por suas contribuições valiosas e seu tempo dedicado a discussões produtivas sobre a pesquisa.

Aos membros da banca de defesa pela disposição em compor esta banca, pela sabedoria, conselhos, sugestões e grandes contribuições para a finalização deste trabalho.

À Universidade de São Paulo e à Faculdade de Economia, Administração e Contabilidade de Ribeirão Preto, por todo suporte e conhecimento. Aos colegas que fiz nessa universidade e me ajudaram no processo: Lourival, Agda, Rafael, Jonny, Julio e Flávio.

Aos funcionários da Faculdade de Economia, Administração e Contabilidade da USP (campus Ribeirão Preto), em especial aos do departamento de pós-graduação, Erika, Matheus, Thiago e Silvio, pela prontidão, ajuda e serviços prestados.

À Universidade do Missouri, especialmente a todos do DASS (Division of Applied Social Sciences), por além de disponibilizar estrutura durante o período de estágio internacional, compartilhou comigo conhecimento, e cuidadosamente me instruiu durante todo o estágio. Aos professores Dr. Willi Myers, Dr. Joe Parcell e, Dr. Michael Cook pela gentileza de me ajudar e me receber no departamento. Aos colegas do Mumford Hall, que um dia espero poder rever: Eleni, Marzia, Abby, Fernando, Fernanda, Felipe, Austin, Laura, Sera, Quyen, Damilola, Emma, Mariano, Annete, Tuka, Fazal, Seungyub. Thanks M I Z Z O U for your welcoming. 

À Capes, por auxiliar financeiramente parte deste estudo. O presente trabalho foi realizado com apoio da Coordenação de Aperfeiçoamento de Pessoal de Nível Superior - Brasil (CAPES) - Código de Financiamento 001.

Aos produtores rurais e prestadores de serviços do Brasil e dos Estados Unidos que foram entrevistados, pela disposição em colaborar com a tese, além dos conhecimentos compartilhados.

A todos que de uma forma ou de outra fizeram e fazem parte de minha vida, contribuindo para minha formação acadêmica e pessoal.

Muito obrigada! 

"Quanto mais eu vivo menos eu acredito na eficiência de iluminações repentinas que não são acompanhadas ou apoiadas por trabalhos sérios, menos eu acredito na eficiência da conversão, extraordinária, súbita e séria, ou na eficiência de paixões súbitas; e mais eu acredito na eficiência do trabalho modesto, lento, molecular e definitivo. Quanto mais eu vivo, menos eu acredito na eficiência de uma extraordinária e repentina revolução social, improvisada, permeável, com ou sem armas e na ditadura impessoal, e mais eu acredito na eficiência do trabalho modesto, lento, molecular e definitivo ".

Peguy, citado por Williamson (1996, p.13)

"A fé é o firme fundamento das coisas que se esperam, e a prova das coisas que se não vêem." Hebreus 11:1 (Bíblia on line, s/d.; s/p.) 



\section{RESUMO}

MASCARIN, A. L. C. (2019) Interferências do ambiente institucional nas estruturas de governança de cadeias do agronegócio. (Tese de Doutorado). Faculdade de Economia, Administração e Contabilidade de Ribeirão Preto, Universidade de São Paulo, São Paulo.

O tema das instituições é importante no ambiente organizacional e na competitividade das empresas. $\mathrm{O}$ presente trabalho tem como objetivo principal estudar a influência do ambiente institucional na escolha das estruturas de governança da firma, abordando, de modo particular, a interferência do sistema judiciário. Segundo a Nova Economia Institucional, algumas formas de governança e relações contratuais apresentam vantagens sobre as outras, a depender de fatores como os custos de transação, valor criado, direito de decisão e incerteza. As organizações, por sua vez, estão inseridas no Ambiente Institucional, formado pelas instituições, suas normas e regulamentos. Da interação entre as instituições e organizações é moldada a evolução institucional de uma economia (North, 1994). Além de pautarem o desenvolvimento econômico, as mudanças no ambiente institucional, nos direitos de propriedade, direito contratual, normas e costumes induzem a mudanças nos custos comparativos de governança das organizações (Williamson, 1993). No Brasil, a terceirização não era vista com bons olhos pelas esferas superiores do Tribunal do Trabalho, pois, a seu ver, a prática provoca prejuízos aos direitos adquiridos pelos trabalhadores. A Súmula 331 do TST proibia a terceirização de atividades consideradas finalísticas para a empresa antes da Lei 13.429 de 2017, causando problemas para as empresas que optavam por desintegrar atividades de seu escopo. A presente tese teve, nas ações judiciais movidas pelo Ministério Público do Trabalho contra empresas do setor do agronegócio, o estímulo para estudar a influência do ambiente institucional na escolha das estruturas de governança. De forma a entender melhor tal influência, a pesquisa foi realizada em dois ambientes institucionais diferentes: o Brasil e os Estados Unidos, sendo justificada a escolha dos países por apresentarem dois sistemas judiciais distintos em relação à origem e à forma que se organizam na resolução de disputas. A análise empírica vale-se da abordagem qualitativa, uma vez que a mudança na legislação brasileira a respeito do tema é recente, e dados quantitativos não estão disponíveis. Foram desenvolvidos estudos de casos nos dois países com produtores rurais para analisar suas estruturas de governança, o valor criado em atividades terceirizadas e a incerteza no ambiente institucional. A incerteza é a variável que faz a ligação da estratégia adotada e da percepção que os produtores têm do sistema judiciáriode seus países. Os resultados dos estudos de caso reforçam que o sistema judiciárioinfluencia nas estruturas de governança das cadeias do agronegócio e que a incerteza desempenha um papel importante nessa escolha. Assim como também o valor criado na transação de terceirização é uma variável relevante durante a tomada de decisão. Por conseguinte, além da contribuição acadêmica, apresenta-se a contribuição para possíveis políticas públicas, que gerariam economia de primeira ordem, e a contribuição gerencial, que alerta para as variáveis que geram economia de segunda ordem. De forma geral, o presente estudo desenvolve uma abordagem para o exame das estruturas de governança, realizando uma interface entre a Economia e Direito, o estudo da Estratégia e a análise do Ambiente Institucional.

Palavras-chave: Estruturas de governança. Estratégia. Incerteza. Ambiente institucional. Sistema judiciário. 



\begin{abstract}
MASCARIN, A. L. C. (2019) Institutional environment interference in agribusiness governance structures. (Doctoral Dissertation). Faculdade de Economia, Administração e Contabilidade de Ribeirão Preto, Universidade de São Paulo, São Paulo.
\end{abstract}

Institutions are an important theme in the organizational environment and in the competitiveness of companies. The main objective of this research is to study the influence of the institutional environment on the choice of the firm's governance structures, in particular the judicial system's interference. According to the New Institutional Economics, some forms of governance and contractual relations presents advantages over others, depending on factors such as transaction costs, value creation, decision-making and uncertainty. The organizations are inserted in the Institutional Environment, formed by the institutions, their norms and regulations. Interaction between institutions and organizations designs the institutional evolution of an economy (North, 1994). Besides shaping economic development, changes in the institutional environment, property rights, contract law, norms and customs induce changes in the comparative governance costs of organizations (Williamson, 1993). In Brazil, outsourcing was not viewed favorably by the Labor Court because, in its opinion, the practice could harm the rights acquired by workers. Sumula 331 of the High Court of Labor prohibited the outsourcing of company's main activities before Law 13.429 of 2017, entailing problems for the companies that opted to disintegrate activities of its scope. This thesis had in the lawsuits filed by the Public Labor Ministry against companies in the agribusiness sector the motivation to study the influence of the institutional environment in the choice of governance structures. In order to better understand this influence, research takes place in two different institutional environments: Brazil and the United States, the choice being justified because they have two different judicial systems regarding legal origin and the form that they are organized for solving disputes. The empirical analysis is based on the qualitative approach, once Brazilian legislation's change about it recent and quantitative data are not available. Case studies have been developed in both countries with farmers to analyze their governance structures, value created in outsourced activities, and uncertainty in the institutional environment. Uncertainty is the variable that links the strategy adopted and the producers' perception of the judicial system in their countries. The results of the case studies reinforce that the judicial system influences the governance structures of the agribusiness networks and that uncertainty plays an important role in this choice. As well as the value created in the outsourcing transaction is a relevant variable during decision making. Therefore, in addition to the academic contribution, the thesis contributes to public policies creation, which would generate first-order economizing. And also managerial contribution to address and to alert managers to the variables that generate second-order economics. In general, the present study develops an approach for the examination of the governance structures, making an interface between Law and Economics, Strategy and the analysis of the Institutional Environment.

Key words: Governance structures. Strategy. Uncertainty. Institutional environment. Judicial system. 



\section{SUMÁRIO}

1. INTRODUÇÃ

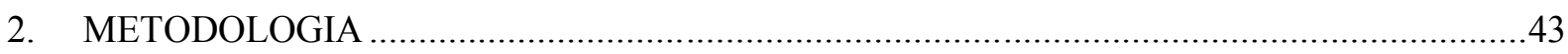

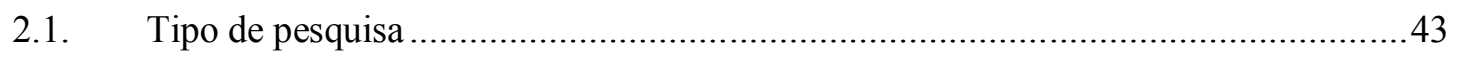

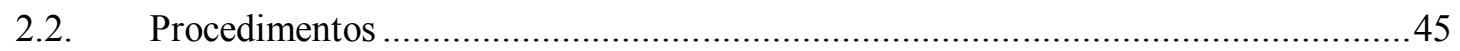

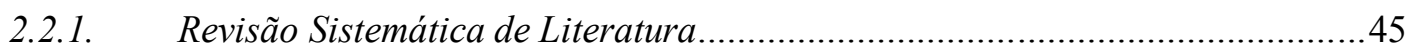

2.2.1.1. Objetivos da Revisão Sistemática de Literatura...............................................46

2.2.1.2. Bases de Dados e Fontes de Pesquisas ..............................................................47

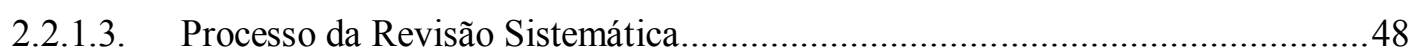

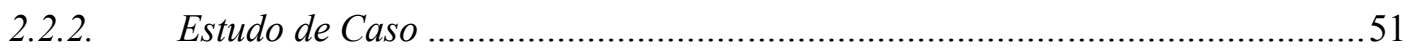

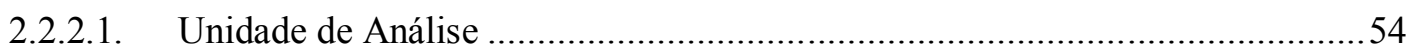

2.2.2.2. Projetos de Casos Multiplos: seleção e determinação do número de casos.......55

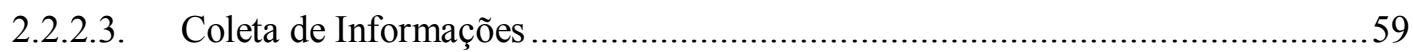

2.2.2.4. Avaliação e análise das informações ................................................................63

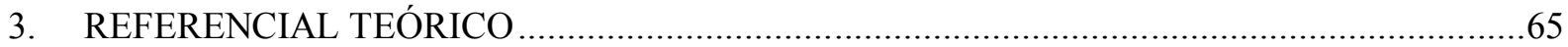

3.1. Teorias sobre estruturas de governança da firma ...................................................66

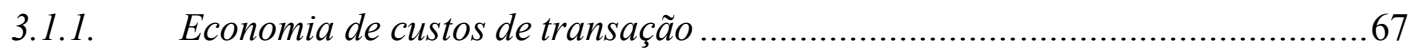

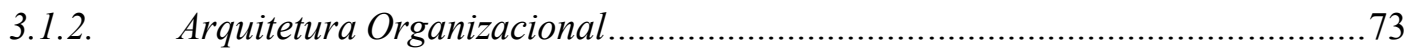

3.1.3. Outras teorias sobre contratos e fronteiras verticais da firma ..........................76

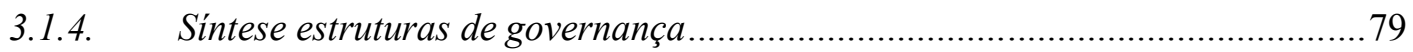

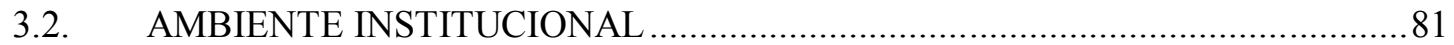

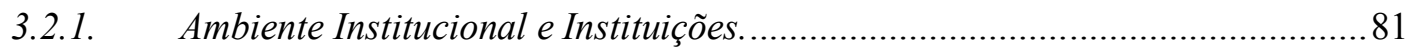

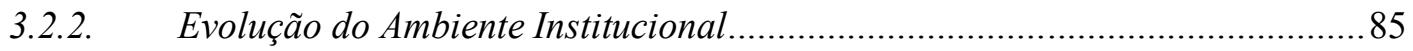

3.2.3. Ambiente Institucional: Estado de Direito e Sistema judiciário /Legal .............88

3.2.4. Sistemas judiciais e economia da eficiência ...................................................92

3.2.5. Sintese da relevância do Ambiente Institucional e suas Instituições. ................97

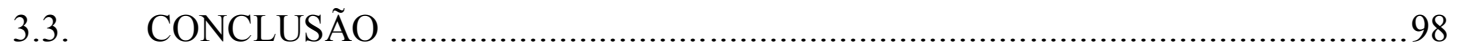

4. EVIDÊNCIAS DAS DIFERENÇAS NOS AMBIENTES INSTITUCIONAIS DO BRASIL E

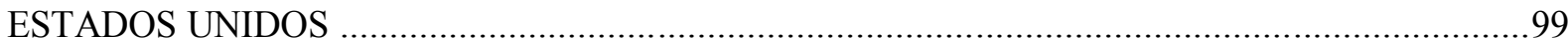

4.1. Origem legal e outros indicadores exógenos das diferenças entre as instituições .....99

4.2. Indicadores de governança do sistema judiciário ................................................... 103

4.3. O sistema judiciário e seus paradigmas contratuais................................................. 106

4.4. Terceirização no Brasil: Súmula 331 do TST e a Lei 13.429 de 2017 ....................111

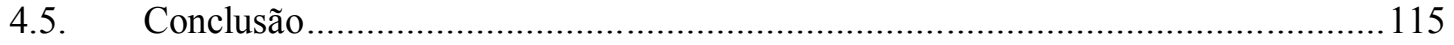

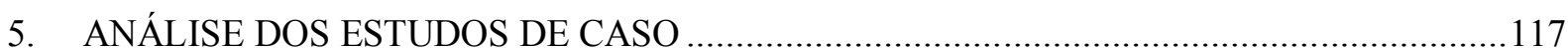



5.1. Terceirização de serviços na agricultura dos Estados Unidos

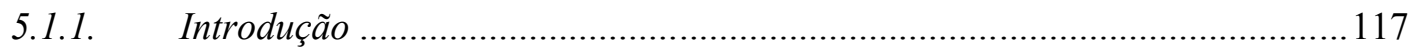

5.1.2. O contexto: a agricultura no Missouri, Estados Unidos .................................119

5.1.3. Perfil das propriedades rurais no Estudo de Caso do Missouri ......................123

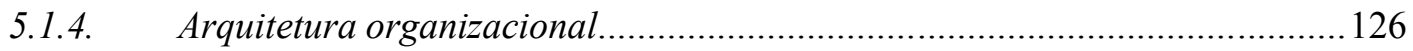

5.1.5. Sistema judiciário nos Estados Unidos ....................................................... 140

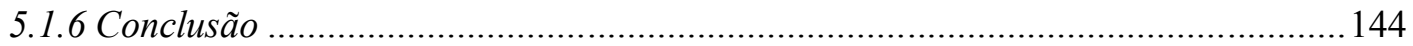

5.2. Terceirização de serviços na agricultura do Brasil ................................................. 145

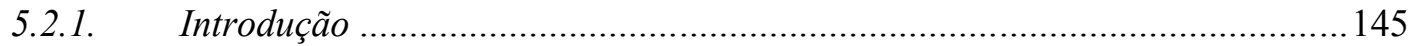

5.2.2. Perfil das propriedades rurais do estudo de caso no Brasil............................150

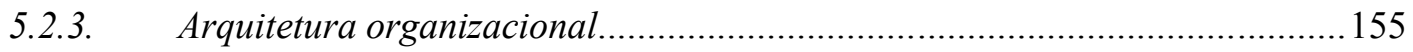

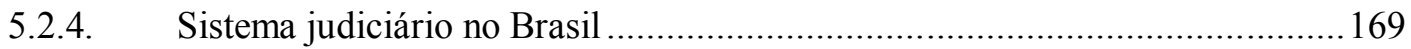

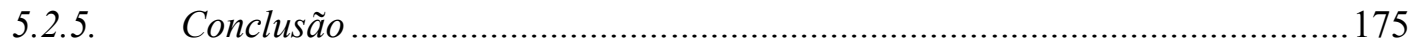

5.3. Análise comparativa entre os estudos de caso: Brasil e Estados Unidos ................. 177

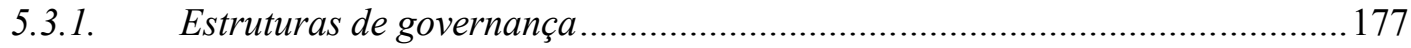

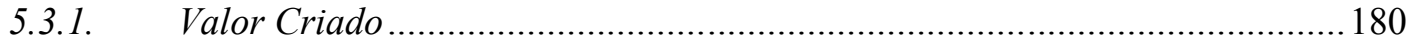

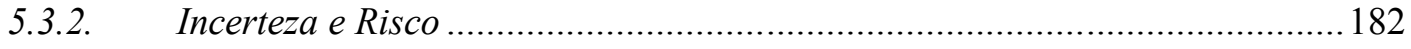

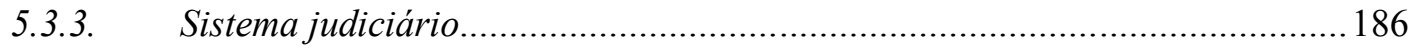

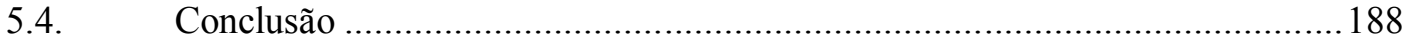

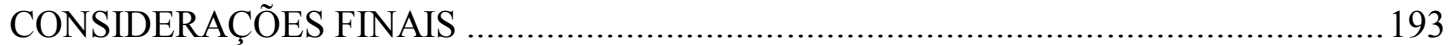

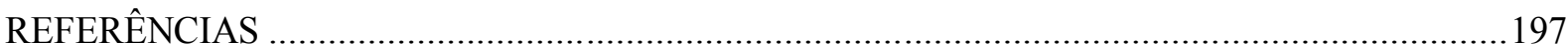

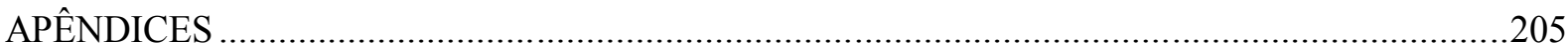





\section{LISTA DE TABELAS}

TABELA 1: BUSCA BIBLIOGRÁFICA NO GOOGLE SCHOLAR PARA REVISÃo SISTÊMICA ........................................49

TABELA 2: BUSCA BIBLIOGRÁFICA NO GOOGLE SCHOLAR PARA REVISÃo SISTÊMICA NA LINGUA INGLESA ...........49

TABELA 3: INDICADORES DE GOVERNANÇA DO BRASIL E ESTADOS UNIDOS.................................................104

TABela 4: VALOR de Mercado dos Produtos Agropecuários dos Estados Unidos .............................117

TABELA 5: IMPACTO do AgRONEGÓCIO NA ECONOMIA DO MiSSOURI ........................................................ 120

TABELA 6: PERFIL FAZENDAS NO ESTADO DO MISSOURI............................................................................. 121

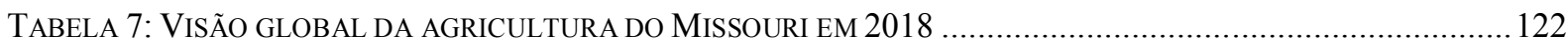

TABEla 8:Perfil do ESTAdo do Missouri: Ranking dos Produtos Agrícolas......................................123

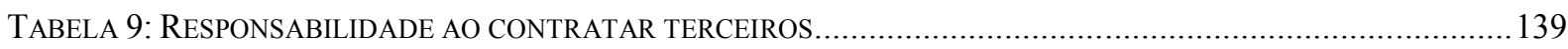

TABELA 10: ATRIBUTOS DO SISTEMA JUDICIÁRIOSISTEMA JUDICIÁRIO DOS ESTADOS UNIDOS ..........................142

TABELA 11: GRAU DE CONFIANÇA NOS MECANISMOS DE SOLUÇÃO DE DISPUTAS.............................................143

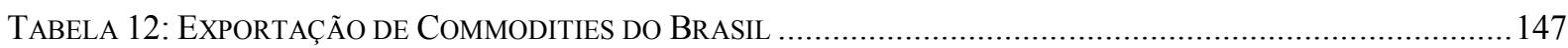

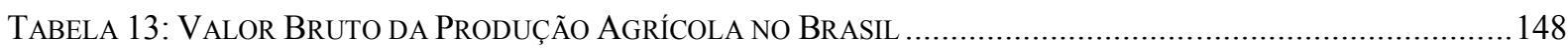

TABELA 14: NúMERO DE ESTABELECIMENTOS AGROPECUÁRIOS E ÁREA DOS ESTABELECIMENTOS ....................151

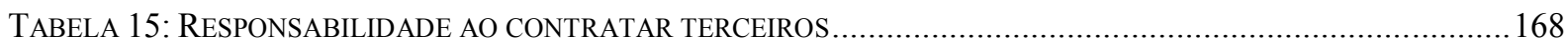

TABELA 16: ATRIBUTOS DO SiSTEMA JUDiCiÁRIOSISTEMA JUDICIÁRIO DO BRASIL NA PERCEPÇÃO DOS

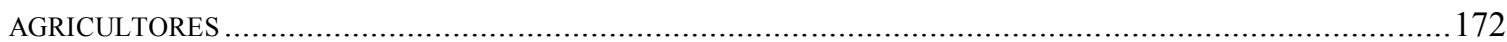

TABELA 17: GRAU DE CONFIANÇA NOS MECANISMOS DE SOLUÇÃO DE DISPUTAS.............................................174

TABELA 18: RESPONSABILIDADE JUDICIAL EM SERVIÇOS DE TERCEIROS NO BRASIL E ESTADOS UNIDOS ............185

TABELA 19: ATRIBUTOS DO SiSTEMA JUDICIÁRIO NO BRASIL E ESTADOS UNIDOS.........................................187

TABELA 20: GRAU DE CONFIANÇA EM MECANISMOS DE RESOLUÇÃO DE DISPUTAS NO BRASIL E ESTADOS UNIDOS 



\section{LISTA DE GRÁFICOS}

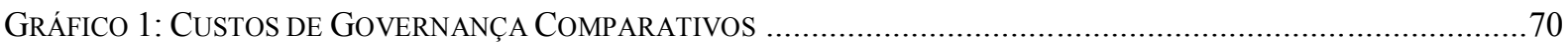

GRÁFICO 2: ÍNDICE DE QUALIDADE REGULATÓRIA DO BRASIL E ESTADOS UNIDOS ............................................105

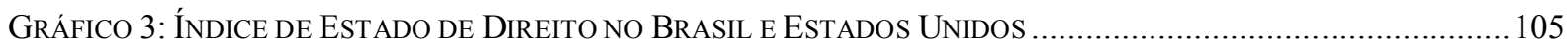

GRÁFICO 4: PARTICIPAÇÃo dO AGRONEGÓCIO NO PRODUTO INTERNO BRUTO NO BRASIL ..................................146

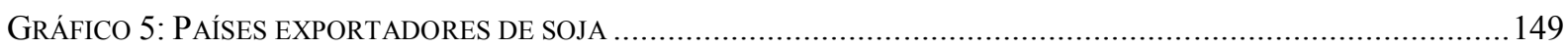

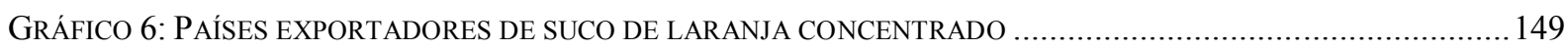

GRÁFICO 9: ESTRUTURAS DE GOVERNANÇA E PRESTADORES DE SERVIÇOS EM GRÃOS NO BRASIL E ESTADOS

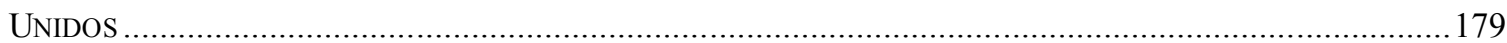





\section{LISTA DE FIGURAS}

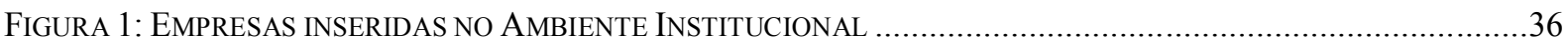

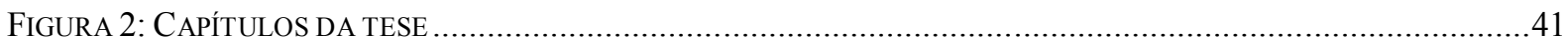

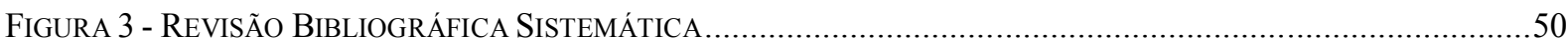

FigURA 4: ETAPAS DO MÉTODO DE ESTUDO DE CASO ............................................................................5

Figura 5: EsTUdos de CASOS: AGRICULTORES do BRASIL E ESTAdOS UNIDOS ............................................57

FigURA 6: CIDADES DOS ENTREVIST ADOS NO MiSSOURI, ESTADOS UNIDOS...................................................58

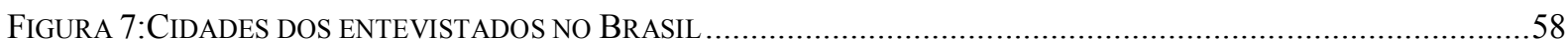

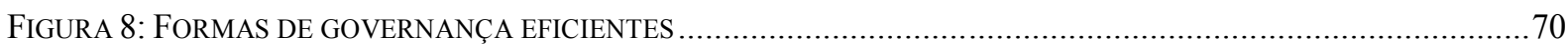

FIGURA 9: ESCOLHA DAS ESTRUTURAS DE GOVERNANÇA NA PRESENÇA DE INCERTEZA .......................................72

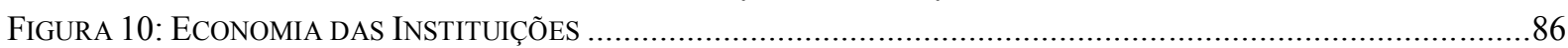

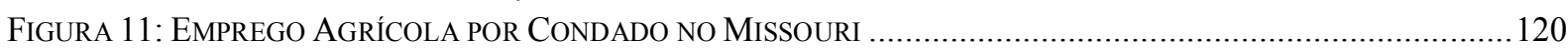

FIGURA 12: ESTRUTURAS DE GOVERNANÇA EM PROPRIEDADES RURAIS DE SOJA NO MISSOURI ..........................127

FIGURA 13: MAPA DAS PROPRIEDADES DO ESTUDO DE CASO NO BRASIL ................................................... 151 



\section{LISTA DE QUADROS}

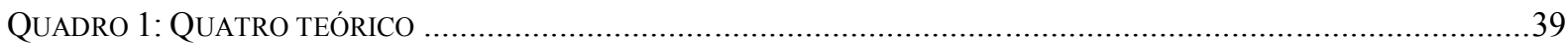

QUADRO 2: BASES DE DADOS UTILIZADAS PARA PESQUISA BIBLIOGRÁFICA ..................................................47

QUADRO 3: REVISÃO SISTEMÁTICA DE LITERATURA EM NÚMEROS ..............................................................48

QUADRO 4: CATEGORIAS DE ANÁLISE, QUESTÕES E ELEMENTOS OBSERVADOS..............................................62

QUADRO 5: BENEFÍCIOS ESPERADOS E RISCOS POTENCIAIS DA TERCEIRIZAÇÃO ..............................................79

QUADRO 6 ATRIBUTOS DA TRANSAÇÃO NA ECT E ATRIBUTOS DO ACORDO NA ARQUITETURA ORGANIZACIONAL 80

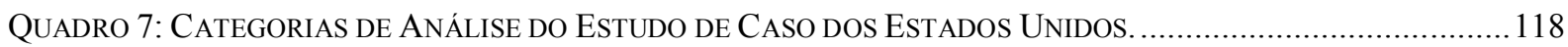

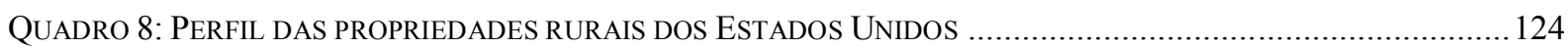

QUADRO 9: TERCEIRIZAÇÃO NAS PROPRIEDADES AGRÍCOLAS DOS ESTADOS UNIDOS ......................................128

QUADRO 10: PERCEPÇÃO NORTE-AMERICANA DE VALOR CRIADO NA TERCEIRIZAÇÃO DE ATIVIDADES................137

QUADRO 11: TOMADA DE DECISÃO DOS PRODUTORES RURAIS DOS ESTADOS UNIDOS. ....................................... 144

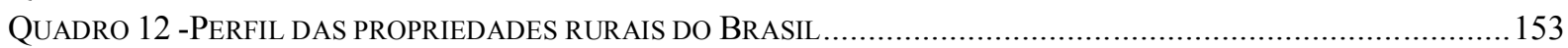

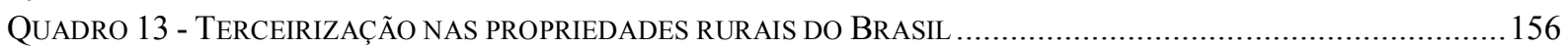

QUADRO 14: PERCEPÇÃO BRASILEIRA DE VALOR CRIADO NA TERCEIRIZAÇÃO DE ATIVIDADES ............................165

QUADRO 15: TOMADA DE DECISÃO DOS PRODUTORES RURAIS DO BRASIL NA CULTURA DE GRÃOS.....................176

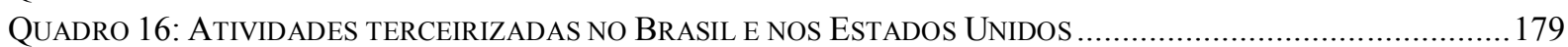

QUADRO 17: VALOR CRIADO NA TERCEIRIZAÇÃO NO BRASIL E ESTADOS UNIDOS ......................................... 181

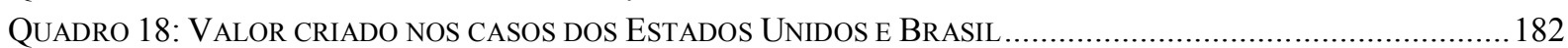

QUADRO 19: RESPONSABILIDADE JUDICIAL NOS CASOS NORTE-AMERICANOS E BRASILEIROS. ...........................186 



\section{INTRODUÇÃO}

O ambiente institucional e instituições são temas inegavelmente importantes quando se discute o desenvolvimento de um país, consistindo o Estado de Direito e o sistema judiciário peças valiosas dentro do ambiente institucional.

No entanto, quando se adentra na caixa preta que é a firma, não existem muitos estudos sobre as estratégias adotadas e resultados da empresa relacionadas ao ambiente institucional. Em vista dessa constatação, o presente trabalho tem como tema central pesquisar a influência que o sistema judiciário de um país pode exercer em empresas do agronegócio quando estas decidem qual o limite de suas firmas, ao optarem estrategicamente por uma estrutura de governança em detrimento de outra.

Muito se discute a respeito dos impactos do ambiente institucional, do Estado de Direito e da qualidade judicial no desenvolvimento da economia e de uma nação, mas quando o assunto é o impacto dentro das empresas, não há muitos estudos que destaquem a associação. Este presente estudo tem, portanto, como problema de pesquisa, a interferência do sistema judiciário no ambiente de negócios e na estratégia das empresas ao decidirem se integram verticalmente uma atividade ou contratam o serviço, constituindo-se o grau de segurança ou a incerteza que ele proporciona aos participantes o ponto mais relevante a ser investigado. Tal incerteza pode afetar a capacidade (eficiência, habilidade, competência) das empresas de realizar contratos com terceiros.

No Brasil, uma das origens de incerteza no ambiente judicial era a falta, até o ano de 2017, de leis e jurisprudências que regulavam os contratos de terceirização; logo, os contratos de serviços eram evitados, uma vez que não havia mecanismos de enforcement ${ }^{1}$ para garantir os acordos. A segunda opção que as empresas tinham era a integração vertical das atividades dentro do escopo da firma, para então evitarem disputas e litígios que não apresentavam legislação específica e clara para serem resolvidos. Essa lacuna no Estado de Direito² frequentemente causava problemas para as empresas que, ao se envolverem em disputas e litígios em relação à terceirização, se deparavam com a inconsonância dos tribunais nos julgamentos relacionados à subcontratação de serviços.

\footnotetext{
1 Enforcement, na Nova Economia Institucional, é um termo que significa a aplicação, cumprimento e execução de medidas legais, no caso os contratos.

${ }^{2}$ Rule of Law é o princípio de que todas as pessoas e instituições estão sujeitas e são responsáveis perante a lei que é aplicada e cumprida de forma justa; o princípio de governar pela lei.
} 
Na falta de legislação específica, o Direito do Trabalho tutelava essa reponsabilidade por meio da súmula 331 do TST, que frequentemente causava desacordo em sua interpretação, uma vez que existia a proibição da terceirização da atividade-fim, porém a interpretação do que era uma atividade fim em uma empresa ficava à mercê do entendimento de procuradores e magistrados, bem como ficava vago o que seria de fato os indícios de precarização3 do trabalho (mão de obra). Essas diferentes interpretações permitiram que o Ministério Público do Trabalho autuasse e processasse empresas do agronegócio por terceirizarem atividades que não eram necessariamente atividades fim em sua cadeia, forçando-as a fazer mudanças em sua estrutura de governança e integrarem verticalmente muitas atividades especializadas e sazonais. Essas autuações que puniram a adoção da terceirização por essas empresas causam impactos maiores que somente os diretamente experimentados por elas, já que afetam, também, as empresas em geral sobre a prática da terceirização, repercurtindo na sociedade como um todo, pois se cria incerteza no ambiente institucional, gera-se insegurança em relação ao enforcement dos contratos, diminui-se o número de transações que ocorre no mercado via contratos e afetam não somente a estratégia das empresas, mas também o crescimento econômico do País.

A origem de estudos sobre estruturas de governança adotadas pelas empresas tem início com o conceito seminal introduzido por Ronald Coase (1937) do paradigma de fazer ou comprar, em que a transação de fatores de produção pode se organizar dentro ou fora do escopo da firma. Coase (1937) sugere estratégias alternativas para organizar a firma, por exemplo, desintegrar atividades do escopo com o intuito de gerar valor. Sob a ótica da gestão, a estratégia de coordenar as transações via mercado ou contratos aumenta em alguns casos a rentabilidade sobre o capital, diminui alguns custos de aprendizado, aumenta o foco da empresa nas atividades centrais, permitindo que ela tenha acesso a serviços melhores e mais especializados.

Os empresários e executivos estão em busca de vantagens competitivas em relação a seus concorrentes, essas vantagens decorrem das muitas atividades que uma empresa desempenha. A cadeia de valor desagrega a empresa em suas atividades, e a firma obtém vantagem competitiva por desempenhar estas atividades de maneira superior a seus

\footnotetext{
3 O termo foi cunhado pela justiça do trabalho e não está definido nos dicionários tradicionais como Aurélio e Michaellis. Em dicionários informais que adotam o entendimento da justiça do trabalho precarização é um substantivo feminino que refere ao processo que torna algo precário, diminuindo sua qualidade e eficiência; ação de tornar precário, ineficiente, inseguro. $\mathrm{O}$ termo jurídico significa um conjunto de alterações relacionadas com o mercado de trabalho e com os trabalhadores, especialmente com a perda e/ou não garantia dos direitos trabalhistas e previdenciários estabelecidos pela lei, resultando numa piora das condições, qualificações e direitos do trabalhador.
} 
concorrentes (Porter, 2001). Parte dessa estratégia para buscar vantagens competitivas é a tomada de decisão de quais alternativas de estruturas de governanças a empresa deve adotar e a decisão sobre a alocação dos recursos, de forma a otimizá-los. A estratégia escolhida visa à busca de eficiência e a custos de transação mínimos para um melhor posicionamento no mercado.

As diferentes formas de coordenar a produção, segundo Farina (1999), impactam diretamente na capacidade de reação a mudanças no ambiente competitivo e na identificação de ações estratégicas. Na análise do agronegócio, Neves (2007) ressalta a importância entender como os agentes da cadeia se relacionam e interagem no processo produtivo. Diversos autores que vêm estudando a coordenação de sistemas agroindustriais (popularmente denominados SAGs). Estudos de Farina, Saes e Azevedo (1997) e de Neves (2008) associam a competitividade do SAG de acordo com a coordenação entre os agentes.

Algumas formas de governança apresentam vantagens sobre as outras, a depender de custos de transação, coordenação dos sistemas agroindustriais (SAGs), custos de produção. Na Argentina, Vilella, Senesi, Dulce e Daziano (2010) relatam mudanças nas estruturas de governança na agricultura como um dos fatores de sucesso na soja. Segundo Senesi, Chaddad e Palau (2013), a produção passou de própria, utilizando terras e recursos próprios, para uma agricultura baseada em contratos de serviços, terra, contratos de locação, contratos de colheita, mercados de contratos futuros, contratos de seguros. O setor agrícola argentino, cada vez mais deslocado do modelo produtivista4, caminhou para um modelo de negócio de grande escala5. Segundo Trucco (como citado em Mascarin, 2014), com o aumento da extensão de áreas produtivas na Argentina, não era viável transportar máquinas próprias, portanto surgiram fornecedores locais de serviços de máquinas agrícolas, baseado em contratos. Naquele país, os fornecedores evoluíram e melhoraram cada vez mais seu nível de profissionalização, de pontualidade, oferecendo mais e melhores máquinas, serviços de melhor qualidade, complementos (GPS, monitoramento por satélite) e novos serviços (monitoramento de pragas).

A empresa, na Nova Economia Institucional, é vista como um nexo de contratos e, portanto, é afetada pelo aparato legal que cerca as transações na transferência dos direitos de

\footnotetext{
${ }^{4}$ O termo produtivista é utilizado por Vilella, Senesi, Dulce, \& Daziano (2010) para definir um modelo de integração vertical.

${ }^{5}$ Para Senesi, Chaddad, \& Palau (2013), o novo modelo de negócios de grande escala agrícola indica que houve expansão para terras de terceiros, a fim de aumentar a produção sem aumentar os custos fixos, utilizando um modelo de contratos.
} 
decisão e propriedade de bens e serviços transacionados. Esse aparato é formado pelas instituições.

O ambiente organizacional e as estruturas de governança, portanto, estão imersos no ambiente institucional, em que as normas e regras regulam as atividades (North, 1994). A Figura 1 apresenta o conceito de Williamson (1993), em que mudanças no ambiente institucional, nos direitos de propriedade, direito contratual, normas e costumes; induzem a alterações nos custos comparativos de transação.

Figura 1: Empresas inseridas no Ambiente Institucional

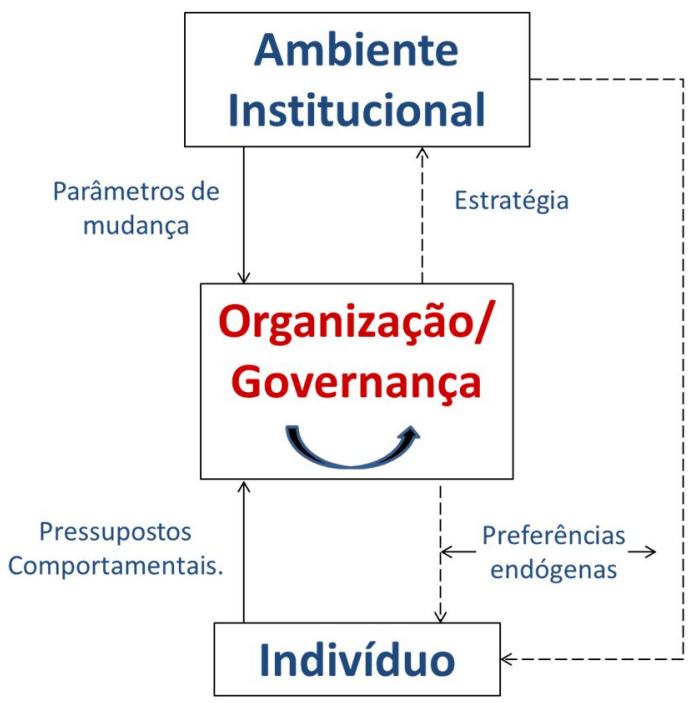

Fonte: traduzido pela autora de Williamson (1993, p. 18).

É a interação entre as instituições e organizações, segundo North (1994) que molda a evolução institucional de uma economia. Se as instituições são as regras do jogo, as organizações e seus empresários são os jogadores. Dessa interação e da evolução das instituições políticas e econômicas surgem ambientes econômicos propícios que induzem ao aumento da produtividade e crescimento econômico sustentado. No entanto, algumas destas interações podem ser prejudiciais para o ambiente econômico e organizacional uma vez que, como observa Coase (1991), na tentativa de regular os mercados o Estado intervém e interpreta como poder de mercado uma relação ou transação sobre a qual não tem completo entendimento.

No Brasil, o tema da subcontratação de serviços foi controverso por um longo período antes da Lei $\mathrm{N}^{\mathrm{o}} 13.429$ (Brasil, 2017) sancionada pelo presidente Michel Temer em $31 / 03 / 2017$, pois enfrentou muita discordância entre as partes envolvidas. Os sindicatos têm 
uma posição diferente dos empresários, procuradores têm entendimento diverso de alguns magistrados e mesmo dentro das categorias há discrepância de opiniões, causando incerteza nos ambientes institucional e organizacional e limitando a tomada de decisão das empresas ao escolherem a estrutura de governança que julgam mais eficientes do ponto de vista dos custos de transações e vantagem competitiva.

Na cadeia produtiva do agronegócio, alguns casos chamaram a atenção no Brasil e motivaram o tema da presente tese. Foi constatado, durante a pesquisa de mestrado feita pela autora da presente pesquisa, (Mascarin, 2014) que algumas usinas sucroalcooleiras foram autuadas pelo MPT e tiveram que assinar um Termo de Ajustamento de Conduta (TAC), no qual se comprometiam a não mais utilizar serviços de terceiros de colheita mecanizada e transbordo, sendo necessário à usina integrar verticalmente adquirindo máquinas para realizar essa atividade internamente. Ou seja, o ambiente institucional interveio diretamente na tomada de decisão dos agentes.

No setor sucroenergético, o Ministério Público do Trabalho da $15^{\mathrm{a}}$ Região de Campinas-SP (processo TST-RR-55700-18.2005.5.15.0074) autuou a Quatá (Companhia Agrícola Zillo e da Companhia Agrícola Luiz Zillo e Sobrinhos) em ação que discute a terceirização do processo de plantio e colheita de cana de açúcar na região dos Lençóis Paulistas. O MPT, naquele caso, desaprovava o modelo de negócios do grupo, que preferiu a desintegração vertical de sua cadeia produtiva, optando pelo fornecimento de matéria-prima de parcerias. Segundo a ação, as parcerias e arrendamentos firmados pelo Grupo para o fornecimento de cana-de-açúcar tinham como arrendatários ex-funcionários da usina que se comprometiam a vender toda a produção obtida para a empresa, sendo responsáveis também pela contratação dos trabalhadores rurais necessários para a produção na propriedade arrendada, o MPT entendeu como forma de precarização da mão de obra, uma vez que a usina não mais seria responsável pelo trabalho e direitos dos funcionários de seus fornecedores e/ou parceiros agrícolas.

A citricultura também foi alvo de ações civis pelo mesmo motivo. O processo 0000121-88.2010.5.15.0081 foi movido contra empresas produtoras de suco de laranja: a Sucocítrico Cutrale Ltda., Louis Dreyfus Commodities Agroindustrial S.A. e Fischer S.A (Citrosuco). Ele determinou que fosse encerrada a terceirização nas atividades de plantio, cultivo e colheita de laranja, em terras próprias ou de terceiros no território nacional, locais que a produção dos frutos seria utilizada em suas indústrias. Ou seja, a decisão é de que essas empresas se tornem totalmente integradas verticalmente, eliminando os produtores agrícolas que fornecem matéria-prima para a indústria de suco de laranja. 
Para entender a influência do ambiente institucional nas empresas, além das ações judiciais que as partes sofrem ao escolher desintegrar uma atividade, a realização de uma comparação das estratégias adotadas em ambientes institucionais distintos torna a análise da presente tese mais relevante. Assim sendo, além de realizar os estudos de caso no Brasil, a pesquisa também foi realizada nos Estados Unidos. A escolha ocorreu primeiramente porque os dois sistemas judiciais são diferentes: o sistema judiciário dos Estados Unidos é baseado na common law, enquanto o brasileiro tem origem na civil law francesa. Além de que, a pesquisa nos Estados Unidos foi conduzida durante a realização do estágio internacional na Universidade do Missouri, nos Estados Unidos.

Dado esse contexto, parte-se para o objetivo central do presente estudo, que é analisar como a incerteza no ambiente institucional impacta nas organizações e influenciam na estrutura de governança adotada por elas. A pergunta central que rege esta tese é 'Como o ambiente institucional, por meio de ações do sistema judiciário, influencia as formas de governança das empresas?'. Esta é a questão central que orienta o presente trabalho, e buscase respondê-la a partir da análise de casos múltiplos em dois ambientes institucionais distintos: o Brasil e os Estados Unidos.

Os objetivos específicos deste trabalho são:

1. Aproximar e traçar um paralelo entre literaturas sobre estruturas de governança: a economia de custos de transação e a arquitetura organizacional.

2. Explorar, mediante um ensaio teórico o ambiente institucional, as instituições e o sistema judiciário do Brasil e dos Estados Unidos.

3. Analisar a percepção dos produtores rurais do Brasil e dos Estados Unidos a respeito do sistema judiciário de seus países.

4. Comparar as estruturas de governança de propriedades agrícolas de diferentes ambientes institucionais por meio de uma análise estrutural discreta da governança de propriedades rurais.

A relevância deste estudo está, primeiramente, no fato de que o ambiente em que as empresas realizam as transações e negócios, além de ter importância para o resultado da empresa, também é relevante no desenvolvimento econômico e social do agronegócio e da nação. Em segundo lugar, porque não há muitos estudos desenvolvidos que relacionam características dos sistemas judiciais com a escolha das estruturas de governança estratégica das empresas. Além das contribuições acadêmicas, este estudo pretende trazer luz para a relação entre o judiciário e o setor privado, bem como apresentar contribuições para políticas públicas que possam beneficiar as diversas partes envolvidas, gerando ganhos para a 
comunidade. $\mathrm{O}$ estudo pretende também apresentar aplicações gerenciais, de forma que as empresas possam ter subsídios para melhor tomada de decisões estratégias.

A pesquisa justifica-se, sobretudo, pela ampliação do conhecimento, na proposta de unir abordagens da área da administração, do direito e da economia para analisar o ambiente organizacional e as decisões estratégicas, assim como analisar os impactos na sociedade e no desenvolvimento do País, bem como também se justifica pela escassez de estudos sobre o tema.

Quadro 1: Quatro teórico

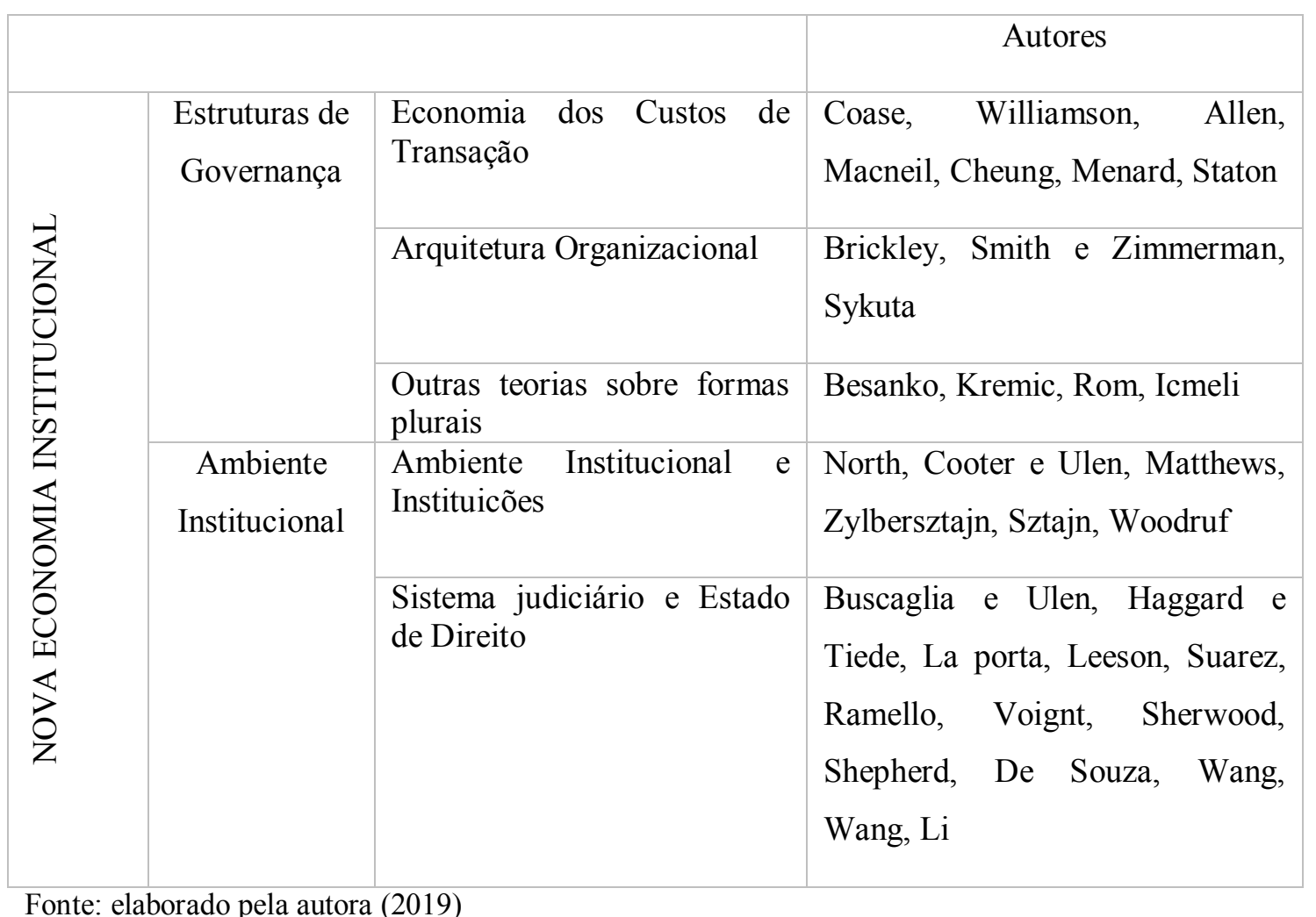

Fonte: elaborado pela autora (2019)

A estrutura conceitual da tese tem a NEI, com os custos de transação e a arquitetura organizacional sendo influenciados pelo sistema judiciário do ambiente institucional que eleva a incerteza e promove que as transações sejam alocadas dentro do escopo da firma, mesmo considerando os outros atributos de especificidade do ativo altos e frequência baixos. Além de alocar as transações majoritariamente dentro da firma, o sistema judiciário e o ambiente institucional impactam diretamente no desenvolvimento econômico do país.

Esta pesquisa está dividida em sete capítulos, conforme apresentado na Figura 2. O capítulo 1 inicia apresentando uma introdução sobre o assunto central da tese, bem como traz 
os principais conceitos expostos no trabalho e a justificativa do tema escolhido. O capítulo apresenta também o problema de pesquisa desta tese, assim como o objetivo geral e os objetivos específicos a serem atingidos. No capítulo 2, é descrito o procedimento metodológico adotado nesta pesquisa para que se possa responder à questão de pesquisa.

No capítulo 3 são expostos os principais arcabouços teóricos que expõem as teorias sobre as estruturas de governança das empresas: a teoria dos custos de transação, a arquiterura organizacional e outras teorias sobre contratos e fronteiras da firma. Segue apresentando a literatura sobre o Ambiente Institucional, as Instituiçoes, e sua evolução, bem como o Estado de Direito e o Sistema Judiciário. No capítulo 4 são evidenciadas as diferenças nos ambientes institucionais do Brasil e dos Estados Unidos.

No capítulo 5 são apresentados e discutidos os resultados dos estudos de casos, realizando-se a análise discreta das estruturas de governança, o valor criado na terceirização de atividades, a incerteza e a percepção do sistema judiciário do Brasil e dos Estados Unidos.

No capítulo 7 são apresentadas as principais conclusões do estudo, bem como suas implicações gerenciais, as contribuições da tese, o cumprimento dos objetivos propostos, limitações da pesquisa e recomendações de pesquisas futuras. 
Figura 2: Capítulos da tese

\begin{tabular}{|l|l|l|l|l|l|l|l|} 
- Introdução \\
-Tema central da Tese, justificativa, problema de pesquisa e objetivos
\end{tabular}

Fonte: elaborada pela autora (2019) 


\section{METODOLOGIA}

O papel desempenhado pelas instituições no desenvolvimento das nações é consenso entre pesquisadores de diversas vertentes (Coase, 1998; Cooter \& Ulen, 2016; Cross \& Donelson, 2010; Haggard \& Tiede, 2011; Hall \& Jones, 1999; LaPorta, Lopez-de-Silanes, Shleifer, \& Vishny, 1998; Matthews, 1986; North, 1991; Saona \& San Martín, 2016; Sherwood, Shepherd, \& De Souza, 1994; Timm, 2009; Wang, Wang, \& Li, 2014; Williamson, 2000; Woodruff, 2006), cumprindo o Estado de Direito e o Sistema judiciário importante função ao garantir a estabilidade ao ambiente institucional e suprir as condições necessárias para o progresso.

As organizações estão imersas nesse ambiente determinado pelas instituições e buscam vantagens competitivas, criação de valor e otimização de resultados. $\mathrm{Na}$ busca por melhores resultados e maior valor as organizações assumem estruturas plurais de governança, que também encontram vasta literatura na Nova Economia Institucional (Cheung, 1983; Coase, 1937; Macneil, 1978; Neves, 2008; Ramello \& Voigt, 2012; Ramos, 2001; Senesi et al., 2013; Stanton, 1978; Sykuta, 2012; Williamson, 1996; Zylbersztajn, 2005). Em sua maioria a literatura foca nos atributos da transação, na especificidade do ativo e no valor criado.

A presente pesquisa pretende investigar o problema de pesquisa sugerido e examinando se existem evidências de que há interferência do ambiente institucional, especialmente do sistema judiciário, nas escolhas das estruturas de governança de empresas em diferentes ambientes institucionais. A pesquisa examina no ambiente institucional, no Estado de Direito e na qualidade do Sistema judiciário percebida pelos agentes, a existência de relação com a decisão de integrar verticalmente uma atividade.

Neste capítulo será delineado o método para responder ao problema de pesquisa. O método como conjunto das atividades sistemáticas e racionais permite alcançar o objetivo proposto na pesquisa de obter conhecimentos válidos e verdadeiros, e segundo Lakatos e Marconi (2003), traça o caminho e a forma a ser seguida com maior segurança e economia, detectando erros e auxiliando as decisões do cientista.

\subsection{Tipo de pesquisa}

A pesquisa precisa de um método adequado ao seu problema, este estudo tem caráter predominantemente qualitativo. A escolha pela pesquisa qualitativa justifica-se, de acordo 
com (Richardson, 2017), por ser a maneira indicada para a investigação de um fenômeno. Também porque a pesquisa relacionada a organizações tem como função a busca pela verdade, reunindo, analisando, interpretando e relatando informações, de modo que tornem mais eficazes as decisões administrativas (Hair Jr, Babin, Money, \& Money, 2005).

Em ciências sociais, as pesquisas são classificadas de acordo com seu objetivo, (Selltiz, Wrightsman, Cook, \& Kidder, 1975) (1) exploratório; (2) descritivo; (3) causal. A pesquisa exploratória é definida pelos autores como aquela cujo objetivo é oferecer maior intimidade com o problema, aperfeiçoar ideias ou mesmo proporcionar uma nova compreensão do problema. A pesquisa descritiva é definida como aquela que tem por objetivo, assim como é sugerido pelo próprio nome, descrever as características de certo fenômeno ou população, ou mesmo descobrir a existência de associações entre as variáveis descritas. A pesquisa causal procura identificar elementos que colaborem para a ocorrência de fenômenos ou mesmo que determine a ocorrência desses fenômenos.

Em relação ao tipo de pesquisa, este estudo tem natureza exploratória e descritiva, pois busca aprofundar o conhecimento sobre o fenômeno da terceirização. Gil (2008) complementa que a natureza descritiva permite o detalhamento do fenômeno e das relações entre os componentes do problema em questão, no caso a escolha dos produtores rurais pelas formas plurais de estruturas de governança (mercado, contratos e empresa) relacionadas ao ambiente institucional que estão inseridos. Além disso, pesquisas exploratórias são importantes porque podemgerar oportunidades para análise dos comportamentos e das necessidades dos objetos de estudo (Hair Jr, Babin, \& Money, 2005).

Assim, a pesquisa qualitativa não busca medir os eventos por meio de técnicas estatísticas para a análise dos dados. Diferentemente, os dados são obtidos por meio do contato direto e interativo do pesquisador com o objeto de estudo. $\mathrm{O}$ pesquisador qualitativo procura basear suas conclusões com base na interpretação dos fenômenos estudados, de acordo com a perspectiva dos participantes-alvo da pesquisa (Neves, 1996). Uma vez que o maior interesse deste estudo está na compreensão do problema, na exploração de ideias, descrição do fenômeno e no aprofundamento do tema, mais focado no entendimento dos fatos do que em sua mensuração, não utilizando métodos quantitativos de pesquisa. "A maioria dos trabalhos qualitativos avança a teoria por meio da construção indutiva, no entanto, dados qualitativos podem ser usados para testar teorias, ou ainda realizar dedução" (Bansal e Corley, 2012, p. 509). 


\subsection{Procedimentos}

São utilizados dois métodos de pesquisa para alcançar os objetivos propostos: i) revisão sistemática de literatura e ii) estudo de caso. Neves e Conejero (2012) destacam que estes os métodos são bastante utilizados nas pesquisas organizacionais.

O presente estudo envolve como procedimentos: pesquisa sistemática da literatura, ou seja, leitura ordenada e crítica de referenciais teóricos e da literatura a respeito do tema. Além da revisão sistemática a pesquisa consiste em dados primários levantados através de entrevistas com produtores rurais em dois países, se tornando, desta forma, um "estudo de múltiplos casos".

Assim, sinteticamente, esta pesquisa compreende os seguintes procedimentos técnicos:

- Revisão sistemática de literatura sobre o tema utilizando a recomendação PRISMA.

- Estudo de caso: a pesquisa de estudo de caso pode incluir tanto estudo de caso único quanto de casos múltiplos, no caso do presente estudo será utilizado múltiplos estudos de casos, os dados serão levantados junto aos produtores rurais.

A seguir serão descritos os procedimentos utilizados em cada um dos métodos da pesquisa qualitativa.

\subsubsection{Revisão Sistemática de Literatura}

A pesquisa bibliográfica é definida por (Oliveira, 2016) como sendo um estudo sobre fontes científicas que tratam sobre algum tema específico, sendo, portanto, a análise de documentos científicos como periódicos, livros, ensaios teóricos, artigos científicos, entre outras fontes. A pesquisa bibliográfica, de acordo com Lima e Mioto (2007), tem sido utilizada com grande freqüência em estudos exploratórios ou descritivos, casos em que o objeto de estudo proposto é pouco estudado, tornando difícil a formulação de hipóteses precisas e operacionalizáveis.

O propósito deste método é permitir ao pesquisador contato direto com tudo o que já foi publicado sobre o tema. Podem ser fontes de dados da pesquisa bibliográfica: jornais, revistas, boletins, livros, pesquisas, monografias, teses e até mesmo meios de comunicação orais (rádio, gravações, filmes etc.), pois ela compreende toda a bibliografia já tornada pública sobre o assunto (Marconi \& Lakatos, 2007).

A pesquisa bibliográfica, para Manzo (1973), citado por Marconi e Lakatos, (2002) é um método que oferece meios para definir, resolver, não somente problemas já conhecidos, 
como também explorar novas áreas onde os problemas não se cristalizam o suficiente, não se tratando apenas de repetir o que já foi publicado, mas permite ao pesquisador conclusões de um determinado assunto sobre uma nova abordagem ou enfoque, podendo chegar a novas conclusões.

No presente estudo, além de realizar a pesquisa bibliográfica tradicional, esta foi refinada através de uma revisão sistemática de literatura. Esse tipo de pesquisa é frequentemente utilizado como ponto de partida para o desenvolvimentode pesquisas e pode ser solicitada por agências de fomento para se assegurarem de que há necessidade de pesquisas adicionais.

A revisão sistemática é uma revisão de uma questão claramente formulada, que utiliza métodos sistemáticos e explícitos para identificar e avaliar criticamente uma pesquisa relevante e coletar e analisar dados, podendo ser utilizados métodos estatísticos (metaanálises) ou não (Moher, Liberati, Tetzlaff, \& Altman, 2009).

A revisão sistemática realizada nesta pesquisa foi baseada no método desenvolvido pelos autores Moher, Liberati e Tetzlaff, que são conhecidos como PRISMA Group.

O PRIMA Group sumariza a revisão de diretrizes para atender a avanços conceituais e práticos na ciência das revisões sistemáticas. Nomeado de diretrizes PRISMA (Principais Itens para Relatar Revisões sistemáticas e Meta-análises) após reunião realizada em 2005. A reunião ocorreu no Canadá com 29 participantes, incluindo autores de revisões, metodologistas, clínicos, editores e um consumidor; seu objetivo era revisar e expandir o checklist e o fluxograma do método.

O método prevê a avaliação de 27 itens em um artigo em quatro fases: i) identificação; ii) triagem; iii) elegibilidade; iv) inclusão. Nesta pesquisa, o objetivo era verificar a importância do tema estudado e a escassez de estudos no campo das instituições que relacionam o ambiente institucional, o sistema judiciário e a estrutura de governança em organizações do agronegócio. Após as três fases realizadas e finalizando a quarta (4), que prevê a inclusão dos artigos com maior relevância, complementou-se essa fase com informações e fontes de outras bases de dados e indicações, não sendo, portanto, o resultado da revisão sistemática a fonte exclusiva da revisão de literatura da pesquisa.

\subsubsection{Objetivos da Revisão Sistemática de Literatura}

Esta etapa foi utilizada principalmente para o delineamento do instrumento de coleta de dados dos estudos de caso utilizados na próxima etapa e para o conhecimento da 
pesquisadora de pesquisas anteriores publicadas sobre o assunto. Nesta fase, utilizou-se como método de pesquisa o método PRIMA e este método de pesquisa foi escolhido por duas razões e objetivos. Inicialmente foi utilizado para (i) identificar as variáveis envolvidas na estratégia de uma organização ao definir uma estrutura de governança que cumpra eficientemente seus objetivos e (ii) na busca de elementos dos ambientes institucionais que pudessem interferir nessas variáveis ou mesmo restringir as opções de arranjos acessíveis.

A partir da revisão sistemática foi possível entender quais condições no ambiente organizacional eram afetadas pelo ambiente institucional e quais fatores do ambiente institucional poderiam causar tais impactos nas estruturas de governança das organizações do agronegócio. A relação entre duas linhas de pesquisa utilizadas nesta pesquisa, uma que envolve condições do ambiente macroeconômico e outra que descreve decisões do ambiente interno da organização, foi estabelecida por meio desta etapa da pesquisa.

A revisão sistemática de literatura teve também como um de seus objetivos a justificativa do presente estudo e a comprovação da raridade do tema de interferências dos sistemas judiciais na escolha estratégica das estruturas de governança.

\subsubsection{Bases de Dados e Fontes de Pesquisas}

O desenvolvimento da revisão sistemática foi realizado por meio de pesquisa a artigos científicos, livros acadêmicos, relatórios científicos, entre outras fontes. Para acessar estes materiais foram realizadas pesquisas em diversos diretórios e bases de dados, bem como foram indicados por docentes durante as orientações. $\mathrm{O}$ acesso foi gerado pela Universidade de São Paulo e pela University of Missouri. Sem o acesso concedido por elas, o acesso a essas bases ficaria muito limitado.

Quadro 2: Bases de dados utilizadas para pesquisa bibliográfica

\begin{tabular}{|l|l|}
\hline \multicolumn{1}{|c|}{ Bases } & \multicolumn{1}{c|}{ Sites } \\
\hline AGRICOLA & www.agricola.nal.usda.gov \\
\hline CABdirect & www.cabdirect.org \\
\hline Emerald & www.emeraldinsight.com \\
\hline Google Books & https://books.google.com \\
\hline Google Scholar & https://scholar.google.com \\
\hline JSTOR & www.jstor.org \\
\hline Scielo & www.scielo.org \\
\hline Scopus & www.scopus.com \\
\hline Web of Science & http://www.webofknowledge.com \\
\hline
\end{tabular}

Fonte: elaborado pela autora (2018) 
Além das bases de dados da figura, foram utilizadas de maneira ampla as bibliotecas das duas instituições, Universidade de São Paulo e University of Missouri, que possibilitou o acesso a diversos livros clássicos das teorias revisadas na pesquisa. O resultado quantitativo da pesquisa bibliográfica tradicional e das referências utilizadas nesta tese pode ser consolidado no Quadro 3.

Quadro 3: Revisão Sistemática de Literatura em números

\begin{tabular}{|l|l|}
\hline \multicolumn{1}{|c|}{ Tipos } & Números \\
\hline Artigos publicados em periódicos acadêmicos & 60 \\
\hline Artigos publicados em congressos científicos & 2 \\
\hline Artigos publicados em periódicos não acadêmicos & 12 \\
\hline Relatórios técnicos, pesquisas empresariais, fontes institucionais, legislação & 19 \\
\hline Dissertações de mestrado & 1 \\
\hline Teses de doutorado & 3 \\
\hline Teses de livre-docência & 1 \\
\hline Livros & 38 \\
\hline Total & 136 \\
\hline
\end{tabular}

Fonte: elaborada pela autora (2019)

\subsubsection{Processo da Revisão Sistemática}

Foi utilizada, para a realização da revisão sistemática, a base de dados do Google Scholar. Alguns termos foram amplamente buscados sem filtros, incluíram-se aspas nos termos compostos para que o termo fosse buscado exatamente da forma digitada. Quando os termos foram combinados para a pesquisa da relação entre os temas foi usada a pesquisa avançada do Google Scholar e a ferramenta 'com todas as palavras' foi utilizada na busca. Em alguns termos como: "estruturas de governança" e "arranjos institucionais", que são utilizados com o mesmo significado de acordo com a preferência da autora, a pesquisa foi duplicada e utilizaram-se os dois nas mesmas relações.

Os resultados que consideravam o ambiente institucional e a relação dele com outros termos foram delimitados por meio do filtro 'desde', para que a busca fosse realizada a partir de 1 de janeiro de 1991, período a partir do qual Douglas North iniciou suas pesquisas focada nas Instituições e publicou o artigo com o mesmo nome, colocando o ambiente institucional em evidência ao afirmar que "institutions matter" (instituições são importantes). Na Tabela 1 é possível verificar os principais resultados na busca por palavras chaves em português e, na Tabela 2, os resultados na língua inglesa. 
Tabela 1: Busca bibliográfica no Google Scholar para revisão sistêmica

\begin{tabular}{l|c|c}
\multicolumn{1}{c}{ Palavras-chave } & \multicolumn{1}{c}{$\begin{array}{l}\text { Resultado Google } \\
\text { Scholar (números) }\end{array}$} & Filtro período \\
\hline "estrutura de governança" & 10.700 & - \\
\hline "arranjos institucionais" & 26.000 & - \\
\hline $\begin{array}{l}\text { "estrutura de governança" OR "arranjos } \\
\text { institucionais" }\end{array}$ & 14.900 & - \\
\hline "ambiente institucional" & 42.300 & - \\
\hline "ambiente institucional" & 16.700 & desde 1991 \\
\hline "sistema judiciário" & 21.700 & - \\
\hline "sistema judiciário" & 15.900 & desde 1991 \\
\hline "sistema judiciário" OR "ambiente institucional" & 15.000 & desde 1991 \\
\hline "sistema judiciário" "ambiente institucional" & 699 & desde 1991 \\
\hline "sistema judiciário" "ambiente institucional" & 142 & desde 1991 \\
"estrutura de governança" & 119 & desde 1991 \\
\hline "sistema judiciário" "ambiente institucional" & & desde 1991 \\
"arranjo institucional" & 28 & desde 1991 \\
\hline "sistema judiciário" "ambiente institucional" & 59 & \\
"arranjo institucional" "agronegócio" & & \\
\hline "sistema judiciário" "ambiente institucional" \\
"estrutura de governança" "agronegócio"
\end{tabular}

Fonte: elaborado pela autora (2018)

Tabela 2: Busca bibliográfica no Google Scholar para revisão sistêmica na lingua inglesa

\begin{tabular}{l|c|c}
\multicolumn{1}{c}{ Palavras-chave } & $\begin{array}{c}\text { Resultado } \\
\text { Google Scholar } \\
\text { (números) }\end{array}$ & $\begin{array}{l}\text { Filtro } \\
\text { período }\end{array}$ \\
\hline "governance structure" & 344.000 & - \\
\hline "institutional arrangements" & 515.000 & - \\
\hline "institutional arrangements" OR "governance structure" & 18.800 & - \\
\hline "institutional environment" & 374.000 & - \\
\hline "institutional environment" & 202.000 & since 1991 \\
\hline "judicial system" & 529.000 & - \\
\hline "judicial system" & 277.000 & since 1991 \\
\hline "institutional environment" OR "judicial system" & 19.600 & since 1991 \\
\hline "judicial system" "institutional environment" & 5.950 & since 1991 \\
\hline $\begin{array}{l}\text { "judicial system" "institutional environment" "governance } \\
\text { structure" }\end{array}$ & 710 & since 1991 \\
\hline $\begin{array}{l}\text { "judicial system" "institutional environment" } \\
\text { "institutional arrangement" }\end{array}$ & 375 & since 1991 \\
\hline $\begin{array}{l}\text { "judicial system" "institutional environment" } \\
\text { "institutional arrangements" "agribusiness" }\end{array}$ & 59 & since 1991 \\
\hline $\begin{array}{l}\text { "judicial system" "institutional environment" "governance } \\
\text { structure" "agribusiness" }\end{array}$ & 41 & \\
\hline
\end{tabular}

Fonte: elaborado pela autora (2019) 
Após a busca inicial, foi realizada a reclassificação dos artigos por 'relevância', filtro da ferramenta de busca do Google Scholar, nos resultados após 1991. Dessa forma, na sequência da busca inicial e da classificação dos resultados por relevância os resultados em que continham os seguinter termos em português e inglês: i) sistema judiciário; ii) ambiente institucional; iii) arranjos institucionais ou estrutura de governança e iv) agronegócio; foram analisados.

Uma vez que segundo Moher et al. (2009), a condução de uma revisão sistemática depende muito do escopo e da qualidade dos estudos incluídos, foram analisados os 87 resultados em português e os 100 resultados da língua inglesa, seguindo a proposta do PRISMA Group. O diagrama com os resultados detalhados de cada etapa pode ser encontrado na Figura 3 - Revisão Bibliográfica Sistemática.

Analisando os 187 resultados totais, 116 títulos foram analisados uma vez que foram encontrados poucos resultados, e 26 resultados foram filtrados para a leitura dos resumos e destes, dez foram lidos na integra, de acordo com a proposta do PRISMA Group, sendo três teses e uma dissertação.

Figura 3 - Revisão Bibliográfica Sistemática

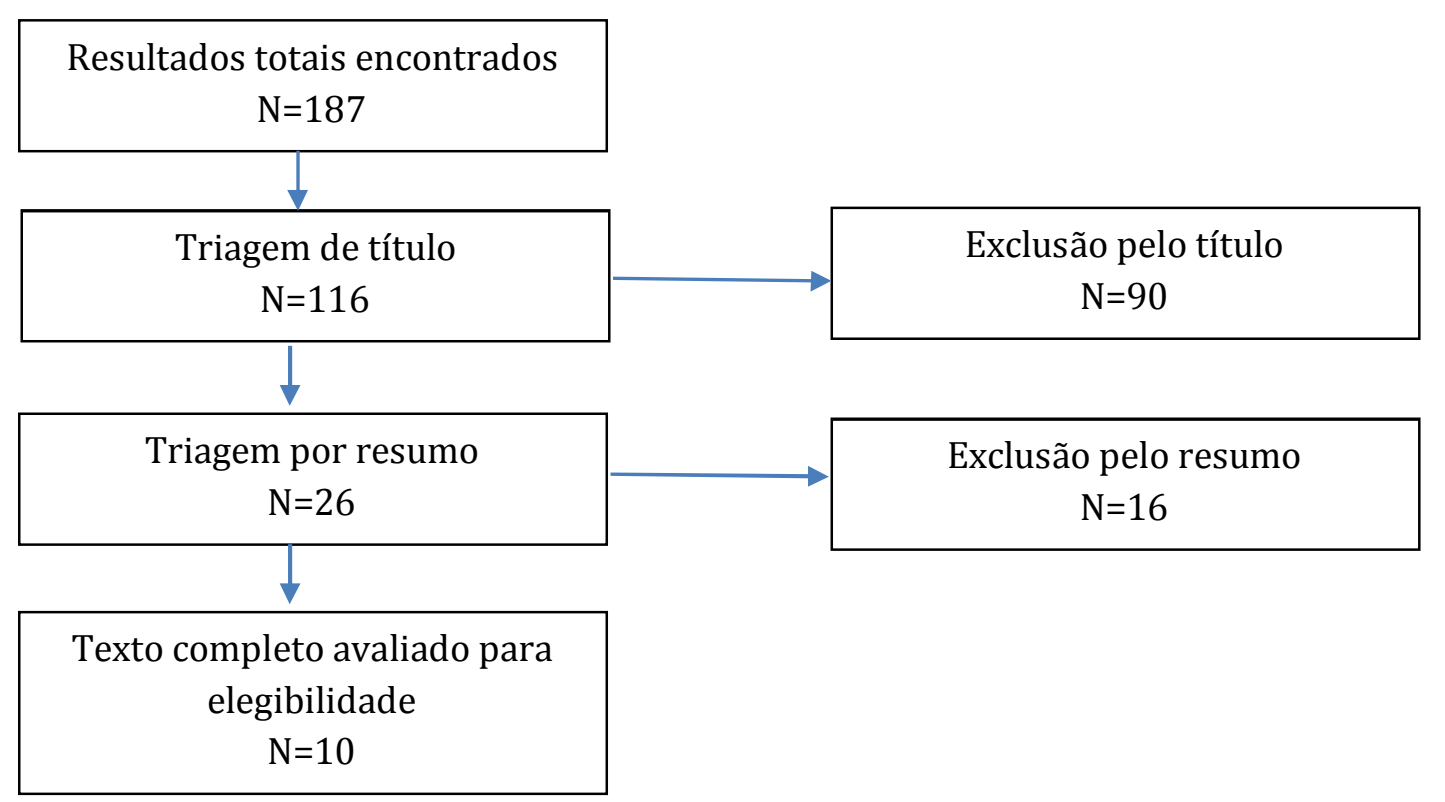

Fonte: elaborado pela autora baseado nas práticas PRISMA (2018)

A análise prévia dos 26 resumos analisados e dos dez artigos lidos na íntegra mostra que não há muitos estudos que buscam no Estado de Direito e no sistema judiciário um fator de influência na explicação da escolha das estruturas de governança no agronegócio. 
Ademais, artigos e obras que tratam do estado da arte dos temas que compõem esta pesquisa também foram utilizados como base para o levantamento de bibliografia. Entre os principais, podem-se destacar:

- Coase (1987) - The Firm, the Market, and the Law.

- Brickley, Smith e Zimmerman (2007) - Managerial economics and organizational architecture

- Farina, Saes e Azevedo (1997) - Competitividade: mercado, estado e organizações.

- North (1981) - Structure and Change in Economic History

- North (1992) - Transaction costs, institutions, and economic performance

- North (2005) - Understanding the Process of Economic Change

- Sztajn e Zylbersztajn (2005) - Direito e Economia: Análise Econômica do direito e das organizações.

- Williamson (1985) - The economics of institutions of capitalism: firms markets, relational contracting.

- Williamson (1996) - The Mechanisms of Governance

\subsubsection{Estudo de Caso}

A segunda etapa da pesquisa tem por objetivo a realização de estudos de caso. A análise de estudo de caso foi escolhida porque o método tem como principal finalidade a pesquisa de um fenômeno da vida real, como é o caso do nosso problema empírico sobre a interferência do ambiente institucional nas estratégias empresariais no que diz respeito às estruturas de governança adotadas. $O$ estudo de caso é uma investigação empírica em profundidade e em seu contexto, ele serve especialmente quando os limites entre o fenômeno e o contexto não são claramente evidentes (Yin, 2010).

O estudo de caso, segundo Yin (2010), não é feito para estudar a prevalência dos fenômenos, por isso suas entrevistas são diferenciadas em relação ao levantamento. Em segundo lugar, o estudo de caso busca cobrir tanto o fenômeno quanto seu contexto propiciando um grande número de variáveis relevantes, o que seria impraticável num estudo quantitativo.

O estudo de caso é definido como sendo a exploração de um sistema limitado, por meio da análise em profundidade de um único caso ou de múltiplos casos dentro de seu 
contexto real, a partir de diversas fontes de informação. As fontes de informações podem ser por meio de documentação (cartas, memorandos, anúncios, estudos formais, recortes de notícias, entre outros), observação direta ou participante (comportamentos ou condições ambientais observadas no local), entrevista (entrevistas em profundidade guiadas por um roteiro), registros em arquivos (como os de uso público, os registros internos, mapas e outros) e artefatos físicos (evidência física) (Creswell, 2007).

$\mathrm{O}$ estudo de caso é relevante em situações que o pesquisador deseja obter generalizações analíticas e não estatísticas, de acordo com Bonoma (1985), e que podem contribuir para a consolidação ou aperfeiçoamento de um referencial teórico. Além disso, segundo o autor, o estudo de caso é uma técnica importante quando o campo teórico pesquisado tem pouco conhecimento acumulado.

Contudo, entre os diversos métodos de pesquisa qualitativa existentes, o estudo de caso pode ser apontado como o mais adotado em estudos organizacionais. Ele é um método de pesquisa poderoso, capaz de descrever fenômenos complexos, com rigor e criatividade, além de gerar bases para o refinamento, ou ainda a construção de novas teorias (De Massis \& Kotlar, 2014).

De acordo com Yin (2010), três condições devem ser respeitadas para selecionar o método de estudo de caso para a pesquisa de campo. A primeira condição está relacionada às questões de pesquisa que devem se concentrar nos tipos "como, ou por quê?"; a segunda condição é a do investigador não ter poder de manipulação sobre os eventos comportamentais reais; e a terceira refere-se ao enfoque sobre eventos contemporâneos em oposição aos eventos históricos.

Sendo assim, a presente pesquisa se enquadra nas três condições para estudo de casos proposta por Yin (2010), pois procura responder questões do tipo "como e por que", sendo: "por que as empresas do agronegócio terceirizam algumas atividades e não outras?"; "por que algumas atividades são integradas verticalmente em alguns países e em outros não?" e "como as variáveis do ambiente institucional influenciam nas escolhas das diferentes estruturas organizacionais?”. No que diz respeito à segunda condição proposta por Yin (2010), o pesquisador não tem controle ou manipulação sobre os eventos reais como o caso do ambiente institucional e as instituições que o compõem ou sobre a escolha estratégica dos produtores rurais e tomadores de decisão em empresas do agronegócio. Já sobre a terceira condição, o enfoque refere-se ao que as condições do ambiente institucional que impactam na gestão do agronegócio, não remetendo a eventos passados, mas sobre a experiência atual. 
Os pesquisadores devem formular um problema de pesquisa e possivelmente especificar algumas variáveis potencialmente importantes, com alguma referência à literatura existente. No entanto, deve-se evitar pensar em relações específicas entre variáveis e teorias, tanto quanto possível, especialmente no início do processo para não limitar a coleta de dados (Eisenhardt, 1989).

"O estudo intensivo de um caso permite a descoberta de relações que não seriam encontradas de outra forma, sendo as análises e inferências em estudo de casos feitas por analogias de situações" segundo Campomar (2011, p.96).

Ademais, a abrangência do método justifica sua utilidade nas pesquisas, uma vez que considera desde o planejamento do estudo até as técnicas de coleta e as análises de dados (Yin, 2010). Pratt (2009) ressaltar a importância da construção de um método cuja consistência seja passível de verificação.

Os autores Voss, Tsikriktsis e Frohlich (2002) também defendem a aplicação do método de estudo de caso, afirmando que as pesquisas que utilizam o método têm alto impacto e podem conduzir a insights novos e criativos, além de ter elevada validade e solidez com executivos, que são os usuários finais da pesquisa na área de administração.

Posto as considerações dos autores sobre métodos qualitativos, foi adotado o método de estudo de caso, considerando o estudo das estruturas de governança de propriedades rurais, bem como a percepção dos agricultores das interferências e impactos nestas escolhas relacionados, sobretudo, ao ambiente institucional.

Dessa forma, será adotada a sequência de etapas proposta por Yin (2010), para construção de um método qualitativo sistemático e verificável, que é destacado na Figura 4, apresentada na página seguinte. 
Figura 4: Etapas do método de Estudo de Caso

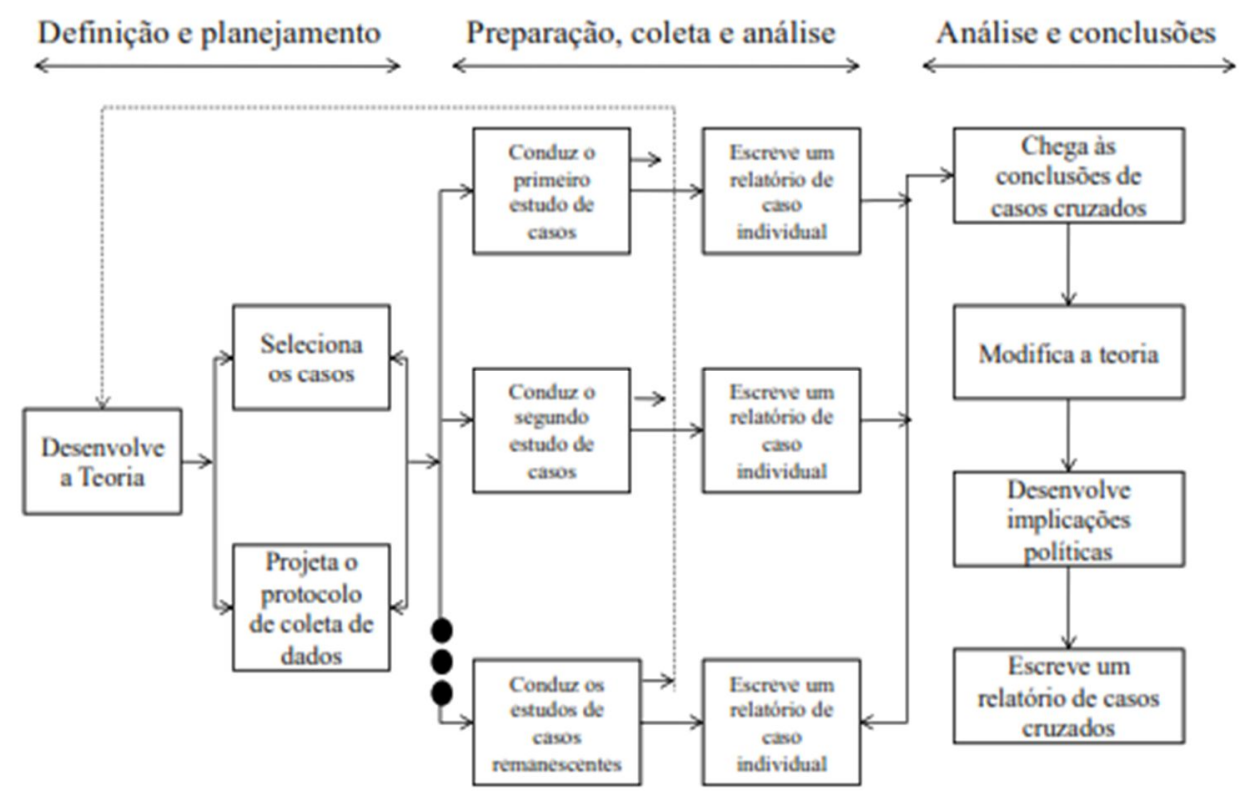

Fonte: Yin (2010, p.72)

Existem algumas etapas que devem ser incluídas na condução de um estudo de caso segundo De Massis e Kotlar (2014). São elas: (1) definição da unidade de análise, (2) seleção dos casos e determinação do número de casos, (3) coleta das informações, (4) avaliação e análise das informações e (5) apresentação e garantia da validade dos resultados.

\subsubsection{Unidade de Análise}

A unidade-caso consiste na delimitação do objeto que será estudado (Gil, 2008). Ao estudar estruturas de governança uma questão fundamental é caracterizar as atividades e transações que ocorrem nas empresas analisadas.

Deve-se destacar que as opções para as empresas organizar as atividades; o mercado, os contratos e a integração vertical; são escolhidas estrategicamente de forma a economizar em custos operacionais e de transação e, portanto, a escolha visa otimização do desempenho da organização. Para isso além de analisar os custos operacionais é preciso considerar os custos de transação presentes e equilibrar fatores nas transações como valor gerado, incerteza e direitos de decisão das partes.

Assim, com base nessa discussão apresentada, a unidade de análise será a estrutura de governança das empresas produtoras de commodities agrícolas (propriedades rurais) e o 
estudo conduzido será a respeito da escolha estratégica de fazer ou contratar atividades produtivas dentro da unidade de análise.

Deste modo estudo de caso será de caráter exploratório e descritivo e visa estudar as estratégias que as empresas assumem em relação à estrutura de governança adotada em diferentes ambientes institucionais e evidenciar a relação entre a escolha dos diferentes arranjos institucionais e a percepção que os agentes têm da qualidade e confiança no sistema judiciário, sendo o sistema judiciário uma instituição importante na garantia dos direitos e na redução da incerteza e do risco presente nas transações celebradas no mercado e por meio de contratos.

São definidas categorias de análise provenientes da teoria para analisar os estudos de caso conforme explicitado na seção 2.2.2.3.

\subsubsection{Projetos de Casos Multiplos: seleção e determinação do número de casos.}

Yin (2010) estabelece quatro alternativas para os estudos de casos: projetos de caso único holístico, projetos de caso único integrado, projetos de casos múltiplos holístico e projetos de casos múltiplos.

Foram feitos múltiplos estudos de caso, porque um único caso não conseguiria captar as estratégias distintas nos diferentes ambientes institucionais e em sistemas agroindustriais complexos, já que cada sistema agroindustrial tem sua coordenação e conta com características peculiares. A justificativa de casos múltiplos deriva do entendimento das replicações literais (Yin, 2010), bem como das diferenças que podem ocorrer entre eles. Segundo o autor, estudos de casos múltiplos são menos vulneráveis que estudos de casos únicos.

Neste sentido, Yin (2010) faz a sugestão do uso de 6 casos para criação ou avanço da teoria. Eisenhardt (1989) reconhece que, embora não haja um número ideal de casos, um número entre 4 e 10 casos geralmente funciona bem. Com menos de quatro casos, geralmente seria difícil gerar teoria com muita complexidade, e sua fundamentação empírica provavelmente não seria convincente, porém com mais de 10 casos, torna-se rapidamente difícil lidar com a complexidade e o volume dos dados.

Gil (2008) ressalta que a utilização de múltiplos casos proporciona evidências inseridas em diferentes contextos, contribuindo para elaboração de uma pesquisa de melhor qualidade. No entanto, não se tem um consenso sobre a quantidade ideal de casos para a 
realização de estudos de caso de qualidade. Existem teorias que foram geradas a partir de um único cas e existe a possibilidade do autor acrescentar mais casos durante o levantamento das informações, caso ache necessário (Eisenhardt, 1989). Entretanto, é preciso que o pesquisador perceba o momento de parar de levantar novas informações e buscar novos casos. Isso pode ser identificado a partir da saturação, ou seja, quando não há incrementos consideráveis a partir dos dados dos novos casos, ou ainda devido ao tempo de análise disponível para o pesquisador (Voss et al., 2002)

É sugerido por Sherwood et al. (1994) que ao comparar diferentes ambientes institucionais os entrevistados tenham contato com os ambientes institucionais diferentes como: (1) estudantes de direito de países de sistemas judiciais fracos que vão para escolas de direito dos Estados Unidos, pois muitos já praticaram no país natal e por isso são candidatos para comparar as diferenças, (2) advogados de empresas multinacionais que atuam em diversos países, (3) membros da família ou da empresa que se dispersam para conduzir negócios ou praticar leis em países de ambiente institucional fracos e fortes.

O estudo de caso da tese é desenvolvido em vários níveis de análise em um único estudo, conforme sugerido por Yin (2010), neste caso o primeiro recorte é nos diferentes ambientes institucionais estudados: o Brasil e os Estados Unidos. Buscando evidenciar em cada um dos dois os fatores que influenciam a tomada de decisão dos produtores rurais em seus respectivos ambientes institucionais, uma vez que a escolha da estrutura de governança pode ser mais bem avaliada em diferentes contextos. Os dois países foram escolhidos primeiramente porque apresentam bastantes diferenças em seus ambientes institucionais, em suas leis e no desenvolvimento econômico e social; conforme apresentado no Capítulo 4.

Além das diferenças institucionais entre os dois países dos casos, eles também foram escolhidos por conveniência porque durante o período da pesquisa a pesquisadora realizou um estágio de doutorado internacional na Universidade do Missouri, nos Estados Unidos e teve a oportunidade de desenvolver parte da pesquisa no país.

O estudo dos dois países, no entanto, é formado por casos particulares dos produtores rurais que fizeram parte do estudo do ambiente institucional. Nos Estados Unidos foram estudados os casos de oito propriedades agrícolas, nove produtores rurais entrevistados, no Estado do Missouri, além de dois prestadores especializados de serviços agrícolas no mesmo Estado americano. No Brasil foram estudadas nove propriedades rurais e uma empresa administradora de um consórcio que presta serviços no País, totalizando 20 casos nos dois países, conforme mostra a Figura 1Figura 5. 
Ocorrendo de um dos casos atender à condição (3) sugerida por Sherwood et al. (1994), de familiares se dispersarem em países diferentes para conduzir negócios, o respondente do caso norte-americano já havia trabalhado em propriedades agrícolas no Brasil por 15 anos e tinha retornado aos Estados Unidos para ajudar na propriedade agrícola do pai, ou seja, já participou na tomada de decisões nos dois países e tem contato com os dois ambientes institucionais.

Os nomes das empresas, bem como características descritivas que pudessem demonstrar quais empresas participaram do estudo foram omitidos. Assim, criou-se uma codificação para que o leitor possa identificar qual propriedade rural ou prestador de serviços está sendo considerada na apresentação e na discussão dos resultados. Para os produtores rurais brasileiros, foi utilizada a sigla "BR" seguida de um número e para os produtores rurais norte-americanos foi utilizada a sigla "US" seguida de um número.

Figura 5: Estudos de Casos: agricultores do Brasil e Estados Unidos

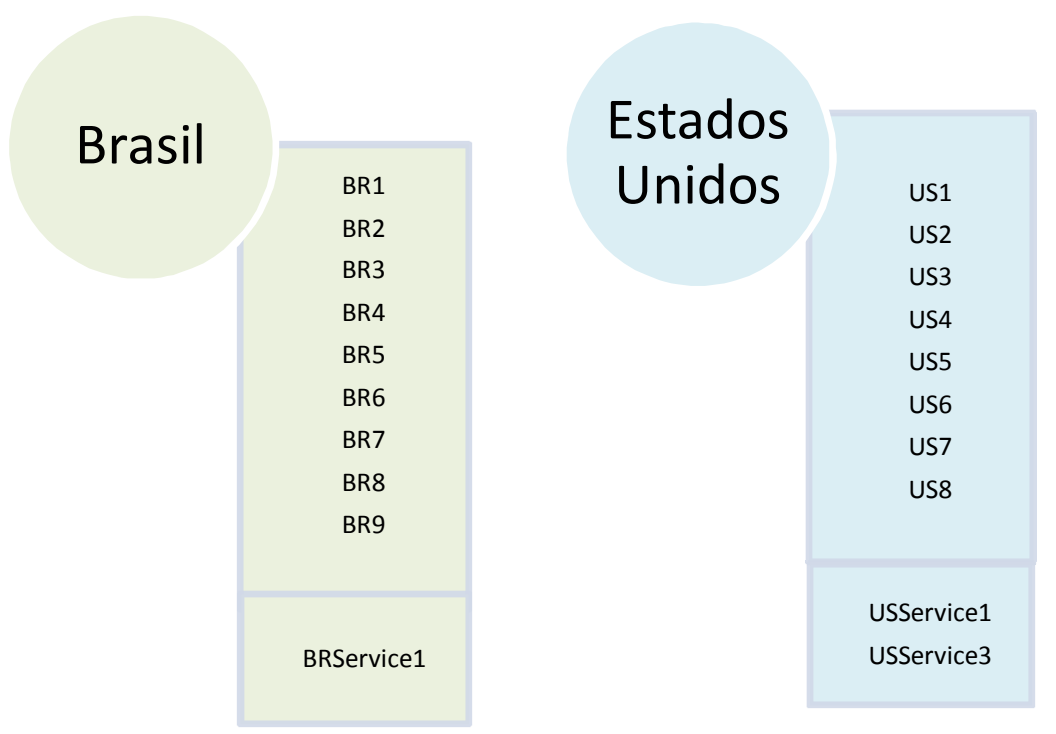

Fonte: elaborado pela autora (2019)

A escolha dos casos foi feita baseada na cultura produzida na unidade de análise, a propriedade rural. Para alcançar uniformidade nas transações analisadas foram selecionadas propriedades rurais produtoras de grãos em um primeiro momento, mas, posteriormente, por algumas propriedades no Brasil serem diversificadas, esse recorte foi ampliado e outras culturas também foram incluídas na análise dos casos. 
Nos Estados Unidos foram realizadas entrevistas nas cidades de St Louis, De Witt, Township, St Charles, Marshall, Blackburn, Waverly, Centralia, Mexico e Kansas City, mostrados na Figura 6 no Mapa dos Estados Unidos.

No Brasil as entrevistas ocorreram ns cidades de Leme-SP, Pirassununga-SP, Agua Boa-MT, Rondonópolis-MT, Porecatu-PR, Teixeira Soares-PR, São Gabriel-RS como plotados na Figura 7.

Figura 6: Cidades dos entrevistados no Missouri, Estados Unidos

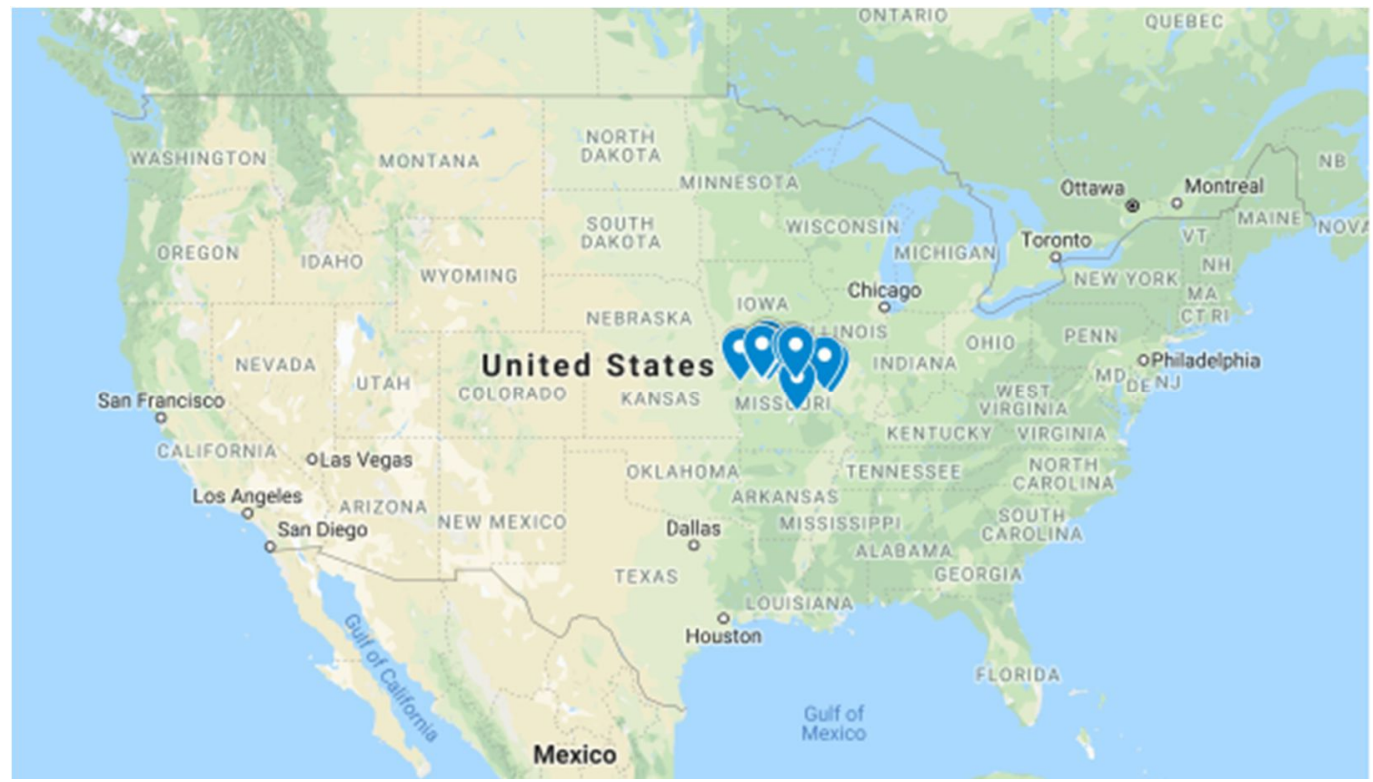

Fonte: Google maps, adaptado pela autora (2018)

Figura 7: Cidades dos entevistados no Brasil

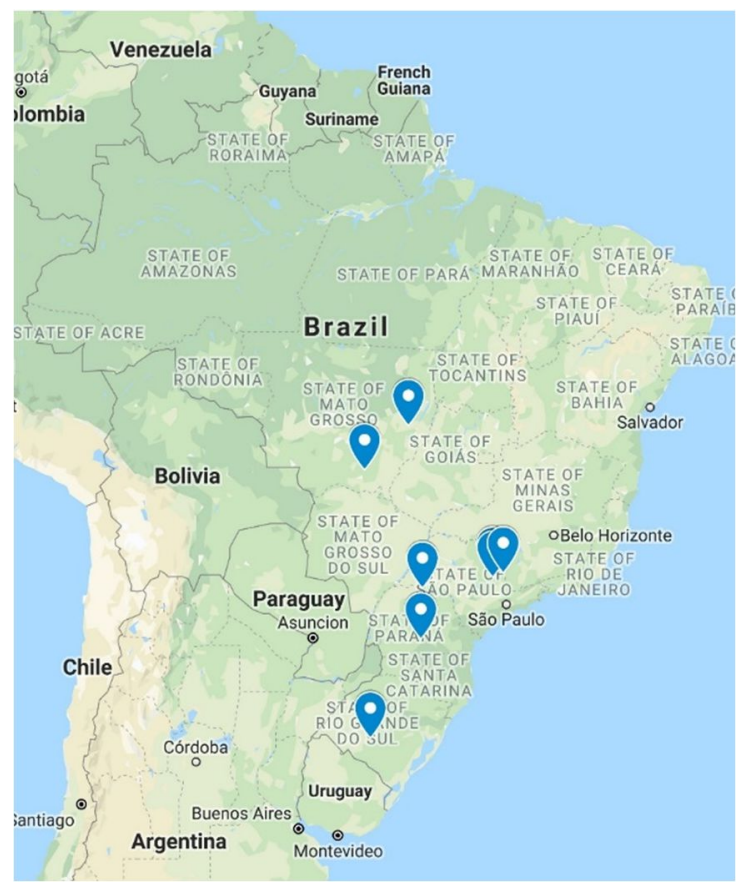

Fonte: Google maps, adaptado pela autora (2018) 
A amostragem dos produtores rurais é não-probabilistica e foi selecionada em um primeiro momento seguindo a técnica de amostragem teórica referida por Eisenhardt (1989). A amostragem teórica, não aleatória, concentra esforços em casos teoricamente úteis - ou seja, aqueles que replicam ou ampliam a teoria preenchendo categorias conceituais. Os casos podem ser escolhidos para replicar casos anteriores ou estender a teoria emergente, ou podem ser escolhidos para preencher categorias teóricas e fornecer exemplos de tipos polares. Embora os casos possam ser escolhidos aleatoriamente, a seleção aleatória não é necessária nem preferível (Eisenhardt, 1989).

A técnica de amostragem teórica seguiu a técnica de amostragem por bola de neve (snowball sampling), em que os indivíduos selecionados indicam outros participantes de sua rede de contatos. A amostra também foi afetada pela disponibilidade dos produtores rurais de participar das entrevistas pessoais na coleta de dados.

Os prestadores de serviço dos Estados Unidos participantes dos estudos de caso foram aleatoriamente incluídos, de uma abordagem telefônica a partir de uma lista proveniente de busca na internet de contatos sobre fornecedores de serviços agrícolas no Estado do Missouri. No Brasil a empresa prestadora de serviços seguiu a lógica da bola de neve e foi indicada por um dos produtores rurais que contrata seus serviços.

\subsubsection{Coleta de Informações}

Yin (2010) ressalta que existem diversas fontes para a coleta de dados dos estudos de casos, entre elas: análise de documentos, entrevistas, registros em arquivos, observações diretas, observação participante e artefatos físicos.

Além das diversas fontes de informações, Yin (2010) destaca que, ao trabalhar com múltiplos casos, é importante que o pesquisador desenvolva um protocolo. A finalidade da existência de um protocolo para o estudo dos casos é descrever as etapas e o instrumento de pesquisa, contendo os procedimentos, as regras gerais a serem seguidas no estudo em questão e também para orientar o pesquisador no ato da coleta de dados e aumentar a confiabilidade da pesquisa. (Yin, 2010).

O protocolo permite ao pesquisador replicar seus estudos, mantendo uma sequência em todos os casos. Dessa forma o método se torna consistente e passível de verificação como sugerido por Pratt (2009). Assim sendo foi desenvolvido um protocolo com base em Yin (2010), disponível no Apêndice 1. 
Como a unidade de análise eram as propriedades rurais, foi desenvolvido um instrumento para a coleta de dados, o instrumento é um roteiro de entrevista semiestruturado para ser aplicado nos produtores rurais responsáveis pela tomada de decisão. Este roteiro foi desenvolvido proveniente da teoria, a partir do referencial teórico da tese, buscando gerar percepções dos elementos pesquisados. Na primeira etapa de elaboração ele foi analisado pela pesquisadora em conjunto com especialistas (professores). Posteriormente o roteiro foi aperfeiçoado após reuniões e discussões com o co-orientador norte-americano, que sugeriu uma abordagem mais aprofundada na incerteza no ambiente institucional $\mathrm{e}$ na responsabilidade judicial afetando as transações. Como resultado, o roteiro de entrevistas para a coleta de dados dos estudos de caso é apresentado no Apêndice 2 e 3 (português e inglês).

Yin (2010) ressalta que algumas pesquisas de estudo de caso vão além da pesquisa qualitativa, usando uma mistura de evidência quantitativa e qualitativa. Eisenhardt (1989) também destaca que apesar dos estudos de caso serem prioritariamente qualitativos, a suplementação com dados quantitativos fornece uma visão sinérgica das evidências. Reforça ainda que algumas evidências quantitativas nos estudos de caso podem indicar relações que podem não ser relevantes para o pesquisador anteriormente também pode impedir que os pesquisadores se deixem levar por impressões vívidas, mas falsas, em dados qualitativos, além de possibilitar reforçar as descobertas quando as corrobora partir de evidências qualitativas.

Em vista disso, são 21 questões mais abertas do que as que se utilizam em um levantamento; e 14 perguntas mais fechadas com o uso de escalas, sendo utilizadas para que se possa possivelmente chegar a algumas evidências quantitativas; todas elas são impreterivelmente imparciais.

Dado que o objetivo do estudo é estudar possíveis influências geradas a partir do sistema judiciário e seus atributos de qualidade e da confiança dos agentes na imparcialidade dos tribunais, a pesquisa compara dois ambientes institucionais distintos, um tido como mais fraco e outro mais forte pelos estudos preliminares. Por fraqueza e força, este estudo considera a existência de um Estado de Direito forte, com leis bem definidas e um sistema judiciário eficiente, eficaz e imparcial. O estudo de caso pretende analisar empresas do agronegócio e como desenvolvem a estratégia de integrar ou terceirizar atividades e qual o papel do ambiente institucional, mais especificamente o sistema judiciário e o Estado de Direito nessas decisões estratégicas.

Desta forma questões do tipo: "Qual influência do ambiente institucional na estratégia da empresa?”, "Há diferenças nas formas de governança entre as empresas nos ambientes 
institucionais diferentes?”, "Qual o risco percebido pelos produtores rurais quando eles decidem qual atividade vão integrar?”; "Qual valor criado por meio da alocação de atividades dentro e fora da empresa?", são questionamentos que orientam a base deste estudo de caso proposto.

As entrevistas semiestruturadas com os agricultores tomadores de decisão nos dois países foram conduzidas com questões a respeito das leis, da responsabilidade judicial e da qualidade das cortes e tribunais em situações semelhantes. As entrevistas foram realizadas pela pesquisadora e tiveram duração média de 60 minutos, elas ocorreram pessoalmente (13 casos), por telefone (cinco casos) ou Skype (dois casos). E quando autorizada pelos participantes gravadas para posteriormente serem transcritas e analisadas, as demais foram feitas notas sobre as respostas durante a entrevista.

A etapa de coleta de dados tem objetivo exploratório, para comparar ambientes institucionais diferentes e as estratégias das empresas nesses dois ambientes em relação a subcontratação de serviços. Uma característica marcante da pesquisa para construir teoria a partir de estudos de caso, segundo Eisenhardt (1989), é a sobreposição freqüente de análise de dados com coleta de dados.

As primeiras entrevistas no Brasil com o instrumento de coleta de dados inicial ocorreram no mês de maio de 2018 até julho de 2018. Nos Estados Unidos, as entrevistas ocorreram de outubro de 2018 a janeiro de 2019 por meio de visitas as propriedades rurais no estado do Missouri. De volta ao Brasil, após a mudança do instrumento de coleta de dados, os entrevistados foram novamente visitados e novas informações foram coletadas, bem como foram realizadas novas entrevistas para o aumento da amostra de produtores rurais em do Brasil.

Inicialmente, o trabalhou identificou quatro categorias a priori de análise proveniente da teoria: estrutura de governança adotada pelas organizações, interferências judiciais que a organização tinha passado, impactos nas estratégias adotadas após as interferências e expectativa de mudanças no ambiente institucional por meio de mudanças na lei. No entanto, após as primeiras entrevistas e durante o período na Universidade do Missouri, verificou-se a necessidade de ampliar o número de categorias para 6 e mudar o foco de outras. Sendo, então, 3 das categorias definidas a priori e 3 categorias a posteriori. Essas mudanças durante a pesquisa legitimam os estudos de caso para construção de novas teorias, defende Eisenhardt (1989), pois o pesquisador está tentando entender cada caso individualmente e com a maior profundidade possível. Essa flexibilidade, porém, não é uma licença para não ser sistemático no levantamento de dados. Em vez disso, essa flexibilidade é um oportunismo 
controlado, no qual o pesquisador aproveita a singularidade de um caso específico e o surgimento de novos temas para melhorar a teoria resultante.

As questões foram elaboradas dentro das categorias de análises e são apresentadas no Quadro 4. São elas (1) a caracterização da propriedade rural; (2) network da empresa e recursos; (3) arquitetura organizacional; (4) interferência do sistema judiciário; (5) percepção sobre o sistema judiciais nos dois países; e, por fim, uma categoria presente somente no Brasil (6) impacto das mudanças no ambiente judicial

Para os prestadores de serviços foram adaptadas e espelhadas as questões de algumas categorias.

Quadro 4: Categorias de análise, questões e elementos observados.

\begin{tabular}{|c|c|}
\hline Categoria de Análise & Elementos Observados \\
\hline $\begin{array}{l}\text { Caracterização da propriedade } \\
\text { rural } \\
\text { Q1, Q2 }\end{array}$ & $\begin{array}{l}\text { - Localização, culturas, tamanho, equipamentos, } \\
\text { colaboradores. }\end{array}$ \\
\hline $\begin{array}{l}\text { Network da empresa } \\
\text { Q3, Q4, Q5, Q14 }\end{array}$ & $\begin{array}{ll}\text { - } & \text { Contratos de terceirização de atividades } \\
\text { - } & \text { Atividades integradas verticalmente } \\
\text { - } & \text { Recursos da empresa }\end{array}$ \\
\hline $\begin{array}{l}\text { Arquitetura Organizacional das } \\
\text { atividades } \\
\text { Q6, Q7, Q8, Q9, Q10, Q11, Q12 }\end{array}$ & $\begin{array}{ll}\text { - } & \text { Valor criado pela transação } \\
\text { - } & \text { Incerteza e Risco } \\
\text { - } & \text { Direito de decisão (estrutura de governança) }\end{array}$ \\
\hline $\begin{array}{l}\text { Interferências do Sistema } \\
\text { judiciário } \\
\text { Q13, Q15, Q17, Q18, Q19, Q20, } \\
\text { Q21 }\end{array}$ & $\begin{array}{l}\text { - } \quad \text { Influência da responsabilidade judicial } \\
\text { - } \quad \text { Levantamento de intervenções judiciais } \\
\text { - } \quad \text { Imprmos de Ajustamento de Conduta (TAC) } \\
\text { - }\end{array}$ \\
\hline $\begin{array}{l}\text { Sistema judiciário } \\
\text { Q22, Q23, Q24, Q25, Q26, Q27, } \\
\text { Q28, Q29, Q30, Q31, Q32, Q33, } \\
\text { Q34, Q35 }\end{array}$ & $\begin{array}{ll}\text { - } & \text { Percepção da qualidade do sistema judiciário } \\
\text { - } & \text { Confiança na imparciabilidade do sistema judiciário } \\
\text { - } & \text { Percepção da responsabilidade judicial } \\
\text { - } & \text { Confiançano nos tribunais e cortes }\end{array}$ \\
\hline $\begin{array}{l}\text { Mudanças no ambiente judicial } \\
\text { (Brasil) } \\
\text { Q16 }\end{array}$ & $\begin{array}{l}\text { - Mudanças esperadas após a lei } \\
\text { - Mudanças de estratégia futura da empresa } \\
\text { - Quais atividades acredita que cabem terceirização? }\end{array}$ \\
\hline
\end{tabular}

Fonte: elaborado pela autora (2018)

Assim, ao todo foram estudados 20 casos, em um estado dos Estados Unidos e quatro no Brasil. Foram estudadas propriedades rurais de grãos, nos Estados Unidos abordaram quatro culturas (soja, milho, sorgo e trigo) e no contexto de diversificação das propriedades 
brasileiras foram abordadas oito culturas (soja, milho, painço, laranja, cana-de-açucar, feijão, café, pastagem). Totalizaram-se 22 horas de entrevistas

Dessa forma, contribuindo para o aumento do conhecimento do assunto entre as partes envolvidas e para contribuir para um melhor ambiente de negócios, menos incerteza e maior desenvolvimento socioeconômico para o setor no Brasil.

\subsubsection{Avaliação e análise das informações}

Existem diversas técnicas disponíveis para a análise de informações qualitativas, tais como análise individual dos casos, análise cruzada dos casos, construção de explicações/descrições e busca por padrões (De Massis \& Kotlar, 2014). Eisenhardt (1989) coloca luz sob o abismo que geralmente separa os dados das conclusões, uma vez que a maioria dos estudos publicados geralmente descrevem os locais de pesquisa e os métodos de coleta de dados, mas dão pouco espaço para a discussão da análise. Porém destaca que, assim como em outros métodos qualitativos, as etapas de coleta de dados e análise dos resultados podem acontecer paralelamente.

Existem alguns equívocos na análise de dados qualitativos, para Pratt (2009), que os pesquisadores devem evitar, como falar muito sobre os dados e não os mostrar para o leitor, realizando as intepretações, porém sem mostrar as evidências; outro erro oposto é mostrar muitos dados sem interpretá-los para o leitor; por ultimo o autor ressalta que, às vezes, o pesquisador tenta transformar dados qualitativos em quantitativos para cortar atalhos nas descrições dos casos.

Há a possibilidade do uso de ferramentas de análises qualitativas (software), tais como ATLAS. ti ou NVivo, para facilitar o trabalho de análise dos dados coletados. No entanto, segundo alguns autores (Burnard, Gill, Stewart, Treasure, \& Chadwick, 2008; Pratt, 2009) a realização das análises de forma manual não inviabiliza a qualidade da pesquisa. Pois, o mais importante é que o pesquisador consiga passar pelas fases de codificação, gerando dados consistentes e organizados para as discussões. Além do que o software não realiza as análises e interpretações dos dados, uma vez que essa é a função dos pesquisadores (Burnard et al, 2008). Nesse sentido, optou-se por realizar as análises sem o auxílio de um software para que a pesquisadora se familiarizasse intimamente com todos os casos individuais, como sugere Eisenhardt (1989), para então permitir que no processo os padrões exclusivos de cada caso surjam para então a pesquisadora promova a generalização de padrões entre eles. 
Dessa forma, os dados coletados foram analisados com o suporte da técnica de análise de conteúdo, seguindo as etapas propostas por Bardin (2008): transcrição das entrevistas; leitura flutuante, recorte e notação. A definição das categorias temáticas foi realizada anteriormente na elaboração do instrumento de coletas de dados, e redesenhadas durante a coleta de dados, conforme descrito na seção 2.2.2.3.

A segunda fase da análise de conteúdo pressupõe uma leitura profunda e repetitiva das transcrições. Foi realizada uma leitura exaustiva, conforme sugerido por Bardin (2008) das 20 entrevistas transcritas.

Após a leitura exaustiva das entrevistas, foram realizados o recorte e a identificação dos trechos mais representativos de cada texto, assim sendo, foi possível a distribuição dos conteúdos de cada categoria gerada com base no referencial teórico do trabalho.

As categorias identificadas seguiram as categorias que foram base para a construção dos roteiros de entrevistas considerando as principais dimensões da tomada de decisões dos produtores rurais: "características da propriedade", "contratos de terceirização", "atividades integradas verticalmente", "estrutura de governança", "motivo para a tomada de decisão", "valor criado pela transação", "incerteza e risco", "responsabilidade judicial”, "intervenção judicial", "qualidade do sistema judiciário ", “confiança no sistema judiciário ”, “imparcialidade do sistema judiciário ", "mecanismos de solução de disputas", "confiança", "mudança na lei".

Esta fase envolveu a leitura dos trechos selecionados para que assim fosse possível interpretar os conteúdos destacados nas notações em relação ao contexto em que foram produzidos. Nesta etapa, também foi feito o confronto dos conteúdos com as categorias estabelecidas, bem como o agrupamento por temas comuns. As categorias temáticas foram definidas, seguindo as partes da estrutura conceitual apresentada nesta tese, que foram base para a análise e o entendimento das estruturas de governança das propriedades rurais e a terceirização de atividades.

Após apresentados os procedimentos metodológicos, no próximo capítulo destaca-se o referencial teórico desta tese. 


\section{REFERENCIAL TEÓRICO}

Este capítulo tem o intuito de caracterizar o problema e apresentar o referencial teórico utilizado para analisá-lo. A teoria é responsável por revelar, elucidar e trazer à luz origens e explicações para os acontecimentos e fenômenos que se vivencia; para que seja possível analisar os princípios e esclarecer os efeitos causados por determinados comportamentos. Tal análise torna os seres humanos capazes de proporem novas práticas que, em última instância, podem levar a melhores decisões e, consequentemente, a melhores resultados.

A presente tese tem como base teórica principalmente a Nova Economia Institucional (NEI), com as contribuições de Williamson (1979, 1985, 1991b, 1996, 2000) na Economia dos Custos de Transação (ECT), e de Douglas North $(1991$, 1994) na relevância das instituições do ambiente institucional. Nos últimos anos, a NEI testemunhou progresso no estudo das instituições e a recomendação de Williamson (2000) é que, na espera por uma teoria unificada, deve-se aceitar o pluralismo das teorias que se complementam. A investigação pretende entender a importância das instituições na tomada de decisão das empresas e na escolha das estruturas de governança da firma.

A Economia de Custos de Transação explora três importantes atributos quando alinha a transação e sua respectiva estrutura de governança: a especificidade do ativo, a frequência e a incerteza; sendo que esses atributos determinam os custos de transação. Na busca por vantagem competitiva e melhor desempenho, as empresas empenham-se em economizar nesses custos de transação ao alinharem os atributos da transação à melhor estrutura de governança para obterem vantagens ao organizar suas transações: no mercado, mediante contratos, ou mediante integração vertical.

Recentemente, outros autores buscam explicar o alinhamento das transações baseados em outros fatores Brickley, Smith, e Zimmerman (1995) propõem a arquitetura organizacional como alinhamento de incentivos ao presumir que o equilíbrio na organização da empresa ocorre como em um banco de três pernas; os fatores considerados no alinhamento são: atribuição de direitos de decisão, sistema de avaliação de desempenho e sistema de recompensa. Sykuta (2012) adapta o conceito para a arquitetura dos acordos em que a estrutura de incentivos procura balancear o valor criado na transação, a incerteza e a atribuição dos direitos de decisões entre as partes.

A incerteza é vista como importante atributo tanto para Oliver Williamson quanto para Michael Sykuta no alinhamento das transações, seja na economia dos custos de transação ou na arquitetura organizacional. A especificidade de ativos e a criação de valor nos acordos são 
também conceitos inter-relacionados, quando existem ativos específicos envolvidos, os custos de transação são maiores, logo existe menor criação de valor em acordos de terceirização.

As empresas e transações estão embutidas em um ambiente institucional que determina as regras do jogo e oferece incentivos ao ambiente de negócios. Este ambiente institucional pode fomentar acordos e desenvolvimento, mas também pode ser fonte de riscos e incertezas e oferecer obstáculos às organizações ao aumentar os custos de transação, gerando entraves à tomada de decisão, aumentando a cautela em determinados acordos, e inclusive impossibilitando algumas transações.

A Nova Economia Institucional também aborda a importância das instituições e seu papel no desenvolvimento de uma nação, além do impacto no ambiente organizacional. Em duas proposições Matthews (1986, p. 906) argumenta que economistas de todas as vertentes, velhos e novos concordam que as "instituições importam" além de que "os determinantes das instituições são susceptíveis a análise".

Dessa maneira, o referencial teórico abordará primeiro as teorias utilizadas nesta pesquisa em relação às estruturas de governança da firma: a economia dos custos de transação (ECT), a arquitetura organizacional e reflexões de outras teorias econômicas e de gestão sobre contratos e terceirização. Posteriormente, irá discorrer sobre o ambiente institucional e as instituições, a evolução e amadurecimento das instituições e, por fim, discutirá sobre o sistema judiciário e seu papel no ambiente institucional, nas transações e no desenvolvimento.

\subsection{Teorias sobre estruturas de governança da firma}

A palavra 'firma' segundo Cheung (1983) é a descrição abreviada de uma maneira de organizar atividades sob arranjos contratuais que diferem daquelas dos mercados comuns de produtos. A tese central de Coase (1937), segundo o autor, é que as diferenças nos custos de operação das instituições (custos de transação) levam ao surgimento de uma empresa para suplantar um mercado. Por um lado, as transações de mercado envolvem produtos ou mercadorias; por outro lado, 'transações das firmas' envolvem fatores de produção.

Para Bolton e Dewatripont (2005) as transações são simples trocas de bens ou serviços por um valor monetário que deve apresentar interesse das partes nos termos dessas transações. A aquisição de fatores de produção como matéria prima, trabalho, bens e serviços ocorrem por meio dessas transações, que podem acontecer no mercado, por meio de contratos, ou internalizada dentro de uma empresa. 
As empresas precisam de bens e matéria prima para produzir. Cheung (1983) presume a propriedade privada de insumos produtivos. Cada proprietário de insumos, portanto, tem a opção de (1) produzir e comercializar bens ele mesmo, (2) vender sua contribuição diretamente, ou (3) entrar em acordo contratual, renunciando o uso de sua contribuição a um agente, em troca de uma renda. A empresa surge com a terceira opção: o empresário ou o agente que detém um conjunto limitado de direitos de uso por contrato direciona as atividades de produção sem referência imediata ao preço de cada atividade, e as mercadorias produzidas são, então, vendidas no mercado.

Existem outras razões para o surgimento da empresa, incluindo a divisão do trabalho, o risco e a coordenação das atividades de produção. Coase (1937) considerou esses fatores e rejeitou a todos. Para ele, os custos de transação constituem a consideração principal. Seu argumento está sujeito à refutação porque a lista de outros fatores plausíveis torna possível conceber que os custos totais de transação podem aumentar à medida que a empresa emerge. Porém, Cheung (1983) considera que a ênfase nos custos de transação não nega o ganho potencial da especialização mediante a divisão do trabalho ou de uma coordenação mais eficiente dos esforços produtivos.

A Economia de Custos de Transação trata a transação como a unidade de análise que deve ser utilizada para entender qual a melhor forma para a empresa estruturar seus fatores de produção e proteger o valor gerado pela própria empresa.

\subsubsection{Economia de custos de transação}

Os insights seminais de Coase (1937), em seu artigo A natureza da firma inseriram no cenário das ciências econômicas e sociais o conceito de que as firmas e as instituições importam (firms and institutions matters) e com isso compreender seu comportamento é importante. Dito isto, Coase (1937) promoveu o paradigma da integração vertical e dos limites da firma (make or buy) e deu início a uma nova perspectiva para abordar a firma, que difere da firma da teoria econômica neoclássica e serviu de base para o desenvolvimento da literatura da Nova Economia Internacional (NEI).

Os estudos de Williamson $(1985,1991 b, 1991 \mathrm{a}, 1996)$ procederam a Ronald Coase, e foram dedicados a abrir a caixa preta da firma, como era então considerada pela economia neoclássica. Williamson dedicou-se a estudar as transações, unidades fundamentais de análise, e delineou um modelo preditivo das escolhas de fazer ou comprar. 
Existe um custo para as transações ocorrerem, o que Williamson (1985, 1991b, 1991a, 1996) chamou de Custo de Transação (CT). Esses custos de transação comparativos justificam a firma escolher fazer certas atividades internamente, contratar um fornecedor externo para realizar a atividade ou ainda comprar o produto no mercado (Williamson, 1996). O método preditivo analisa a transação e alinha com a escolha ótima das estruturas de governança disponíveis e factíveis; assim, o mercado, os contratos e a firma (denominada também de hierarquia) são formas alternativas de administrar a mesma transação. $O$ arranjo escolhido depende dos atributos da transação e busca a minimização dos custos de transação.

Os custos de transação, considerados por Williamson (1985, p. 20), são:

os custos ex-ante de preparar, negociar e salvaguardar um acordo bem como os custos ex-post dos ajustamentos e adaptações que resultam, quando a execução de um contrato é afetada por falhas, erros, omissões e alterações inesperadas. Em suma, são os custos de conduzir o sistema econômico.

Eles são utilizados para comparar custos de planejamento, adaptação e tarefas de monitoramento em estruturas de governança alternativas.

A Economia de Custos de Transação de (Williamson, 1979) apresenta três principais atributos com o propósito de descrever a transação: (i) especificidade dos ativos presentes na transação, a (ii) incerteza envolvida na referida transação, e a (iii) frequência com que ela ocorre. A mais importante é a especificidade do ativo, definida como o investimento específico feito pelos agentes para que aquela determinada transação possa ocorrer, aumentando a possibilidade de apropriação de valor caso haja hold up6 da outra parte envolvida. A ausência de especificidade do ativo é caracterizada quando há a possibilidade do ativo ser realocado para usos alternativos, sem afetar o seu valor. Para Williamson (1985, 1996), quando a especificidade de ativos não existe, os custos de transação são baixos e o mercado é a melhor forma de governança. Por outro lado, à medida que a especificidade aumenta, as formas contratuais e de integração vertical são mais eficientes para protegerem a apropriação de valor da outra parte.

Dentro dos conceitos de especificidade do ativo, Williamson (1996) descreve seis tipos: 1) especificidade de localização; 2) especificidade física; 3) especificidade do ativo humano; 4) especificidade dedicada; 5) capital da marca e 6) especificidade temporal.

Williamson (1991b) em seu artigo Strategizing, Economizing and Economic Organization argumenta que economizar em custos de transação (economizing) está associado

${ }^{6} \mathrm{O}$ hold up surge quando parte do retorno dos investimentos específicos de um agente é expropriada pela outra parte engajada na transação. Ele ocorre quando as partes de uma transação fazem investimentos específicos antes que a transação ocorra e as contingências relacionadas às especificações da transação não podem ser determinadas antecipadamente com certeza. 
à melhor escolha estratégica. $\mathrm{O}$ tratamento de eficiência que ele aborda é predominantemente tratado pela perspectiva da economia de custo de transação como uma análise comparativa entre arranjos alternativos factíveis.

No livro The economic institutions of capitalism, Williamson (1985, p. 65) transita pelas abordagens que Macneil descreve para então propor a sua visão de governança eficiente. Macneil (1978) aborda o direito contratual clássico, em que os indivíduos são racionais e esforçam-se por prever as contingências futuras de uma transação. Para essa situação de racionalidade plena, o autor usa o termo discreteness; neste caso, a identidade das partes é irrelevante e a participação de terceiros na arbitragem da transação é desencorajada. $O$ destaque é dado às normas legais, documentos formais e transações de auto liquidação. Ou seja, bem parecido com o mercado 'ideal' de transações spot.

Já o direito contratual neoclássico reconhece a complexidade do mundo, em que os acordos são incompletos, e que alguns contratos nunca serão alcançados, a menos que ambas as partes tenham confiança no sistema de liquidação. São levantadas por Macneil (1978, p. 70) duas características no planejamento dos contratos de longo prazo para que eles funcionem melhor em um mundo de racionalidade limitada e oportunismo, que é a existência de lacunas e de flexibilidade, permitindo ajustes aos contratos, quando necessário.

Macneil (1978, p. 71) contrasta o sistema neoclássico e a abordagem dos contratos relacionais, em que a pressão para sustentar relações em curso rompe com a abordagem neoclássica, que tem no acordo original firmado o ponto de referência para efetuar adaptações. Nos contratos relacionais, a complexidade e a duração dos contratos resultam no deslocamento dos ajustes, onde o ponto de referência para adaptações torna-se a "relação inteira como ela se desenvolveu no tempo, incluindo ou não um contrato original”.

Após as proposições de Macneil (1978), Williamson (1985) propõe diversas formas de governança resumidas pela Figura 8 - Formas de governança eficientes (vide página seguinte), em que as escolhas dos das estruturas de governança são feitas conforme as características de especificidade dos investimentos e a frequência das transações: 
Figura 8: Formas de governança eficientes

\begin{tabular}{|c|c|c|c|}
\hline & & \multicolumn{2}{|r|}{ Caracteristicas do Investimento } \\
\hline & & Não Especifico & Idiossincrático \\
\hline \multirow{2}{*}{$\begin{array}{l}\frac{\pi}{U} \\
\frac{C}{\mathbb{U}} \\
\frac{D}{d} \\
\frac{d}{4}\end{array}$} & $\begin{array}{l}\bar{N} \\
\frac{0}{2} \\
. \frac{0}{N} \\
\mathbb{U} \\
0\end{array}$ & \multirow{2}{*}{ 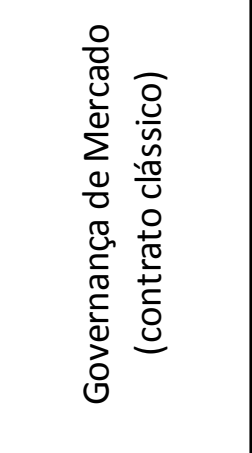 } & $\begin{array}{c}\text { Governança } \\
\text { Trilateral (contrato } \\
\text { neoclássico) }\end{array}$ \\
\hline & 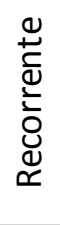 & & $\begin{array}{c}\text { Governança Bilaterali Integração Vertical } \\
\text { (contrato relacional) }\end{array}$ \\
\hline
\end{tabular}

Fonte: traduzido de Williamson, 1985, p. 79

De forma simplificada, Williamson $(1985,1996)$ apresenta no Gráfico 1 somente a especificidade do ativo envolvido, denominado ' $\mathrm{k}$ ' no eixo $\mathrm{x}$, que é mostrado com os custos comparativos de governança no eixo y para o fornecimento eficiente.

\section{Gráfico 1: Custos de Governança Comparativos}

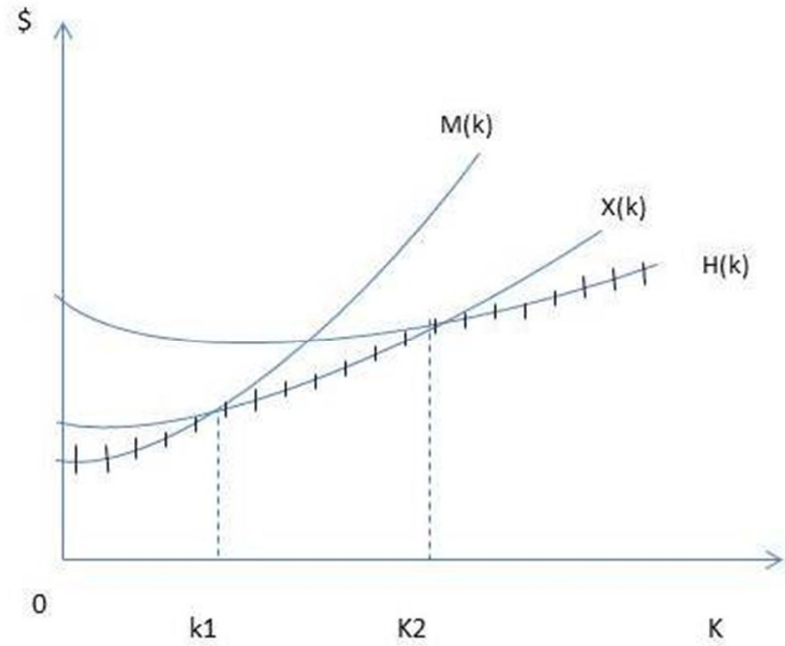

Fonte: Williamson (1996, p.108)

Em síntese o que é proposto é:

- I, usar os mercados para $\mathrm{k}<\mathrm{k} 1$;

- II, uso de formas híbridas, $\mathrm{k} 1<\mathrm{k}<\mathrm{k} 2$, e

- $\quad$ III, uso de hierarquia para k> k2. 
A questão da incerteza é levantada por Williamson (1979), que aponta como a governança das transações é afetada pelo aumento do grau de incerteza. As transações sem especificidade do ativo são aquelas para as quais a continuidade tem pouco valor, já que novas relações comerciais são facilmente organizadas. Aumentar o grau de incerteza não altera a organização das transações sem especificidade de ativos. Consequentemente, a utilização do mercado continua e o paradigma de contratação discreta (direito contratual clássico) mantém-se em transações padronizadas de todos os tipos, independentemente do grau de incerteza.

O assunto é diferente, de acordo com Williamson (1979), com investimentos específicos na transação. Sempre que os investimentos são idiossincráticos, aumentar o grau de incerteza torna mais importante que as partes planejem um mecanismo para 'resolver as coisas' - já que as brechas contratuais serão maiores e as ocasiões para adaptações sequenciais aumentarão em número e importância quanto mais o grau de incerteza aumenta.

A incerteza tem especial relevância para a organização de transações com atributos de investimento mistos, afirma Williamson (1979). Existem duas possibilidades: i) uma seria sacrificar recursos de design valorizados em favor de um bem ou serviço mais padronizado, sendo aplicada, então, a governança de mercado; ii) a segunda seria preservar a especificidade, mas cercar a transação com um aparato de governança elaborado via contratos, facilitando, assim, uma tomada de decisão mais adaptativa e sequencial. Contratos mais elaborados com aparato de arbitragem podem ser planejados para transações ocasionais, fora do padrão. As estruturas de governança bilaterais, muitas vezes, dão lugar à integração vertical à medida que aumenta a incerteza para transações recorrentes.

Reduções na incerteza, é claro, justificam a mudança de transações na direção oposta. À proporção que a incerteza diminui à medida que uma indústria amadurece, o que é o caso usual, os benefícios da integração presumivelmente diminuem (Williamson, 1979). As relações de especificidade do ativo, frequência e incerteza são resumidas na Figura 9, apresentada a seguir. 
Figura 9: Escolha das estruturas de governança na presença de incerteza

\begin{tabular}{|c|c|c|c|c|c|c|c|}
\hline & \multicolumn{3}{|c|}{ ESPECIFICIDADE DO ATIVO } & \multicolumn{3}{|c|}{ ESPECIFICIDADE DO ATIVO } \\
\hline & & NAO ESPECIFICO & MISTO & IDIOSSINCRATICO & NAO ESPECIFICO & MISTO & IDIOSSINCRATICO \\
\hline \multirow{2}{*}{ 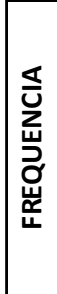 } & $\begin{array}{l}\overline{0} \\
\frac{0}{5} \\
\frac{0}{5} \\
\frac{0}{0}\end{array}$ & Mercado & Contratos & $\begin{array}{c}\text { Contratos/ } \\
\text { Integracao } \\
\text { Vertical }\end{array}$ & Mercado & $\begin{array}{c}\text { Integracao } \\
\text { Vertical/ } \\
\text { Contratos }\end{array}$ & $\begin{array}{c}\text { Integracao } \\
\text { Vertical }\end{array}$ \\
\hline & 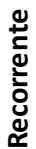 & Mercado & Contratos & $\begin{array}{c}\text { Integracao } \\
\text { Vertical }\end{array}$ & Mercado & $\begin{array}{c}\text { Integracao } \\
\text { Vertical }\end{array}$ & $\begin{array}{c}\text { Integracao } \\
\text { Vertical }\end{array}$ \\
\hline & & \multicolumn{3}{|c|}{ Baixa ou Media incerteza } & \multicolumn{3}{|c|}{ Alta incerteza } \\
\hline
\end{tabular}

Fonte: adaptado de Williamson (1979)

A incerteza não é o atributo mais relevante da transação na pesquisa de Williamson (1979, 1985, 1991a, 1993, 1996, 2000), mas desempenha papel importante quando relacionamos a transação ao ambiente institucional.

Os estudos de North (2005) apontam que a incerteza tem uma longa história na literatura econômica; normalmente retorna-se à definição de Frank Knight que se apoia nos critérios de probabilidade para distinguir o risco da incerteza. Em seu estudo de 1921, Knight aponta que os seres humanos têm um impulso onipresente para tornar seu ambiente mais previsível, e, portanto, transformar incertezas em riscos. Heiner complementa, em 1983, que toda vez que um ser humano se encontra em uma lacuna em que não tem competência de tomar uma decisão sobre um assunto complexo, ele constrói regras para restringir a flexibilidade de escolhas. Ao canalizar as escolhas para um conjunto menor de ações, é possível melhorar a capacidade do agente de controlar o ambiente; embora não haja implicação de que as percepções do agente estejam corretas; essas regras são conhecidas como as instituições como citado em North (2005).

Para garantir o bom andamento das transações, North (1994) enfatiza a importância das instituições no enforcement dos contratos e acordos firmados. Sem elas, para fazer cumprir os contratos muitos ganhos potenciais ficariam inexplorados, porque uma parte ou ambas enfrentariam o medo de que a outra não cumprisse o acordo e evitariam fazê-lo.

As instituições, segundo North (2005) têm sido e continuam sendo o esforço dos seres humanos para estruturar o ambiente para torná-lo mais previsível. O desenvolvimento de direitos de propriedade bem especificados, por exemplo, tornará o ambiente mais previsível. Um dos maiores quebra-cabeças a serem explicados é como, e em que condições, são criados mercados com custos de transação baixos, para aumentar o bem-estar material das partes que se envolvem nas atividades econômicas. 
Para além dos atributos das transações, na escolha estratégica de como organizar a firma, Williamson $(1985,1991 \mathrm{a}, 1991 \mathrm{~b}, 1996)$ insere dois pressupostos comportamentais: a racionalidade limitada e o oportunismo. O primeiro diz respeito à capacidade cognitiva limitada de receber, armazenar, recuperar e processar informações dos indivíduos, fazendo com que a pessoa não seja totalmente racional em suas decisões. O segundo pressuposto diz respeito à busca ávida auto interessada, sendo o indivíduo capaz de utilizar informações privilegiadas a seu favor e extrair quase-rendas do participante que não as possui.

Segundo Bolton e Dewatripont (2005), existem fatores que dificultam o cumprimento dos acordos, podendo comprometer a transação. Os contratos surgem como forma de amparo à transação, para controlar a variabilidade e mitigar riscos, aumentando o valor da transação ou de um conjunto complexo de transações (Zylbersztajn, 2005). São utilizados para coordenar relações complexas e salvaguardar de quebra contratual oportunista caso exista algum tipo de especificidade envolvida na transação que possa levar à apropriação de renda de uma das partes.

\subsubsection{Arquitetura Organizacional}

Da literatura financeira, Brickley et al. (1995) propuseram uma estrutura (framework) para analisar problemas organizacionais e projetar organizações mais efetivas, à qual chamaram de arquitetura organizacional. Eles propuseram três aspectos da organização corporativa nesse framework: i) a atribuição de direito de decisão dentro da empresa, ii) os sistemas e ferramentas para avaliar a performance e iii) os métodos de recompensar os indivíduos pela performance. O termo arquitetura organizacional foi introduzido para adicionar à estrutura hierárquica os sistemas de avaliação e recompensa de desempenho que antes eram ignorados.

Nesse sentido, os três componentes da arquitetura organizacional - a atribuição de direitos de decisão, o sistema de avaliação de desempenho e o sistema de recompensas - são altamente interdependentes. A arquitetura organizacional é descrita como um 'banco de três pernas': trocar uma das três pernas sem considerar cuidadosamente as outras duas é tipicamente um erro - elas devem ser projetadas juntas para manter o banco estável.

A abordagem da arquitetura organizacional de Brickley et al. (1995) usa as ferramentas básicas da economia para examinar o efeito no valor da firma de decisões como centralização versus descentralização, o uso de medidas de desempenho objetivas versus subjetivas, a compensação de funcionários por meio de remuneração fixa versus variável e a 
alocação de atividades dentro da empresa versus terceirização. A arquitetura organizacional baseia-se na teoria econômica de que os indivíduos fazem escolhas, e essas escolhas são respostas aos incentivos.

Para além da arquitetura das organizações Sykuta (2012) adaptou o conceito de arquitetura organizacional para a natureza dos acordos, em que três variáveis se equilibrariam como na banqueta de três pernas da arquitetura organizacional de Brickley et al. (1995). Os acordos alocam em sua estrutura i) valor, ii) incerteza (e os riscos relacionados a ela) e iii) os direitos de decisões entre as partes, de uma maneira que se equilibrem, no acordo, os interesses das partes à luz da assimetria de informação, incentivos e potencial de oportunismo.

Cada transação consiste em três problemas de alocação na arquitetura dos acordos proposta por Sykuta (2012). Primeiramente, a alocação do valor criado pela troca, sendo o valor da transação não necessariamente determinado pelo valor intrínseco do bem ou serviço sendo transacionado, mas pelo valor criado. No caso das transações business-to-business, o valor do bem é melhor determinado pelo modo como o comprador pretende usar o bem para criar valor adicional a jusante.

Em segundo lugar, toda transação envolve algum grau de incerteza que será alocado entre as partes. À medida que a duração de uma transação aumenta ou à medida que a complexidade de uma transação aumenta, o grau de incerteza aumenta junto com o número de fontes de incerteza. $\mathrm{O}$ valor dos contratos como promessas que são legalmente executáveis está em lidar com a incerteza sobre se as partes honrarão suas promessas, ou seja, lidar com a incerteza comportamental entre as partes. A maneira como os termos do contrato aloca a incerteza entre as partes determinará qual parte arcará com os riscos associados à incerteza. Existe, portanto, a necessidade de instituições que abarquem a incerteza sobre o futuro e todas as possíveis condições ambientais e econômicas que possam incentivar uma parte a se comportar de maneira diferente da que ela originalmente concordou.

Finalmente, toda transação requer que certas decisões sejam tomadas, e esses direitos de decisão são alocados entre as partes. Quem toma as decisões relacionadas ao contrato tem implicações significativas no valor criado pela transação, no nível de incerteza que afeta a transação e na maneira que os riscos associados a essa incerteza são sustentados.

A atribuição de direitos de decisão é um elemento fundamental do acordo. Do ponto de vista da economia organizacional, os direitos de decisão devem ser alocados onde eles adicionam mais valor à empresa. Uma boa tomada de decisão requer tanto o conjunto adequado de conhecimentos quanto o acesso às informações necessárias. Os direitos de 
decisão, idealmente, devem ser alocados com as informações especializadas necessárias para a tomada efetiva de decisões.

No entanto, a natureza e as fontes de valor e incerteza, os tipos de direitos de decisão disponíveis para as partes e as informações resultantes e as questões de incentivo são diretamente influenciadas pelo contexto regulatório e de mercado.

Assim como os três aspectos da arquitetura organizacional funcionam em conjunto para afetar o desempenho organizacional, o equilíbrio entre as variáveis do acordo também afeta o desempenho e o desenho de contratos. Qual das partes está mais bem posicionada para tomar decisões que se relacionam com o valor da transação? Quais incentivos são criados pelas alocações especificadas de valor e incerteza? Qual das partes detém os direitos de decisão padrão em casos de contratos incompletos e quais incentivos prevaleceriam nesses casos? Essas questões e suas implicações para o valor da transação precisam ser consideradas ao avaliar qual a melhor estrutura.

Da mesma forma como na arquitetura organizacional, essas três partes são interdependentes e se alinham como um banco de três pernas que mantem os acordos equilibrados, essas três dimensões da estrutura devem estar alinhadas com os objetivos da transação e devem ser projetadas de modo a complementarem-se mutuamente para garantir um desempenho eficaz (Sykuta, 2012).

No capítulo do livro Managerial Economics and Organizational Archithecture sobre integração vertical, Brickley, Smith e Zimmerman (2007) trazem três razões potenciais para transações ocorrerem dentro do escopo da empresa, i) os custos de contratar por causa da especificidade do ativo, dificuldade de medir qualidade, externalidades e problemas de coordenação; ii) o aumento dos lucros exercendo poder de mercado e iii) os impostos e a regulamentação. Além do poder de mercado que a empresa pode se beneficiar em certas condições se for integrada verticalmente e dos menores custos de transação, devido à dificuldade de lidar com externalidades que podem surgir dos acordos os autores trazem os impostos e a regulamentação também como uma razão para integrar uma atividade.

Brickley, Smith e Zimmerman (2007) ressaltam que alguns segmentos são mais regulamentados e têm mais restrições que outros, logo, as empresas talvez busquem menores restrições no ambiente de negócios. No Brasil, a regulamentação e as restrições quanto à terceirização eram uma barreira para as empresas contratarem; porém, mesmo com a nova lei que autoriza a prestação de serviços, ainda existem vários aspectos no ambiente judicial que tornam a incerteza maior no ambiente institucional brasileiro. Existem estudos no Brasil (Almeida \& Zylbersztajn, 2012; Azevedo \& Silva, 2007; Rezende \& Zylbersztajn, 2012) que 
indicam que a incerteza no ambiente institucional apresenta efeitos de segunda ordem no ambiente organizacional e dificultam o andamento de acordos e transações que ocorreriam se houvesse maior estabilidade, maior enforcement dos contratos e menos problemas de hold up e oportunismo.

\subsubsection{Outras teorias sobre contratos e fronteiras verticais da firma}

Os custos de transação são um dos motivos mais discutidos quando se aborda o assunto integrar uma atividade ou 'comprar' a solução por meio do mercado ou de contratos com empresas independentes. Contudo, existem outros motivos, oriundos da economia neoclássica e da literatura de administração, que influenciam na criação de valor em cada uma das estratégias escolhidas pelos tomadores de decisão.

Alguns deles serão retomados nesta seção, para que a pesquisa não fique limitada à literatura da Nova Economia Institucional, que tem na especificidade do ativo, na frequência e na incerteza da transação variáveis que determinam a estrutura de governança da firma, embora seja a referência de maior importância nesta tese.

Segundo Besanko, Dranove, Shanley \& Schaefer (2012), as vantagens de 'comprar' algo no mercado, seja pelo mercado balcão ou por contratos elaborados para suprimento de produtos e serviços, encontram na economia de escala, na economia de aprendizagem e nos custos de influência suas principais razões.

A vantagem da economia de escala quando se recorre à subcontratação ou compra de uma empresa terceirizada independente está em que, por vezes, a empresa terceirizada agrega as demandas de muitos compradores potenciais, enquanto a empresa integrada verticalmente produz para suas próprias necessidades. As empresas independentes e especializadas podem, portanto, alcançar uma escala maior e, por conseguinte, apresentarem menores custos unitários do que a empresa a jusante que utiliza o insumo ou serviço.

Muitas vezes, os analistas afirmam que grandes empresas sofrem os efeitos da 'burocracia', termo genérico que inclui os custos de agência e de influência de acordo com Besanko et al. (2012). Os custos de agência, segundo a compilação dos autores, são os custos associados à negligência profissional e aos controles administrativos necessários para prevenir essa negligência. Tais custos de agência reduzem a lucratividade da empresa porque os trabalhadores agem segundo interesses próprios, que não necessariamente são alinhados com os objetivos da empresa. Em uma empresa verticalmente integrada, o problema da agência pode passar despercebido pela gerência. Os custos de influência são relativos à ineficiência de 
alocar as atividades internamente na empresa quando a decisão de alocar os recursos é movida pela influência de departamentos internos que impedem a empresa de acessar empresas independentes especializadas.

O desejo de economizar em custos é o principal motivador da terceirização em organizações, elas frequentemente esperam a realização d a atividade da mesma forma ou melhor a um custo geral mais baixo.

Em teoria, segundo Bers (1992) e Harler (2000) (citados em Kremic, Rom, \& Icmeli Tukel, 2006) a terceirização por motivos de custo pode ocorrer quando os custos dos fornecedores são baixos o suficiente para que, mesmo com custos indiretos, de lucro e de transação, os fornecedores ainda possam oferecer um serviço por um preço mais baixo. Em sua revisão sobre terceirização, Kremic et al. (2006) presumem a partir dos trabalhos de Klainguti (2000), Ashe (1996), Kakabadse (2000), Quinn et al. (1990) e Roberts (2001) que a especialização e economias de escala são os mecanismos utilizados para atingir esse nível de eficiência.

Outro benefício destacado por Fontes (2000) e Hubbard (1993) é de que ter menos funcionários requer menos infraestrutura e sistemas de suporte, o que pode resultar em uma organização mais ágil e eficiente. Algumas organizações terceirizam para obter um melhor controle de custos segundo estudos de Alexander e Young (1996) e Sheehan (1993); enquanto outras tentam transferir os custos fixos para custos variáveis como apontado por Anderson (1997) e Kremic et al.(2006).

A busca por menores custos pode levar empresas a terceirizar, no entanto, há evidencias observadas por Kremic et al.(2006) que essas economias são superestimadas e que alguns custos podem aumentar após a terceirização, uma vez que existem custos indiretos que podem incluir monitoramento e supervisão de contratos, geração e aquisição de contratos, custos intangíveis e custos de transição. A mensagem na revisão de literatura realizada pelos autores indica que o desejo de redução de custos impulsiona muitas iniciativas de terceirização, e que podem existir economias significativas. No entanto, a economia não é garantida, pois os efeitos da terceirização no custo de uma organização ainda estão sendo estudados e as variáveis e seus relacionamentos são mais complexas do que parecem.

Conforme pesquisa de Kremic et al. (2006), o ponto de vista estratégico também leva empresas a terceirizarem atividades; em geral a literatura sustenta que a terceirização pode oferecer melhor performance no negócio em várias dimensões. A razão estratégica mais frequentemente citada é que, optando pela terceirização de algumas atividades, a organização se concentre melhor em suas competências essenciais. Uma vez que no ambiente competitivo 
as organizações precisam avaliar e direcionar os recursos, que normalmente são escassos, esses normalmente são redirecionados para onde eles causam o impacto mais positivo, isto é, as principais atividades da organização.

Estrategicamente, Anderson (1997) destaca a qualidade como um fator relevante e pode ser uma influência positiva ou negativa na terceirização. No caso, a qualidade dos serviços de uma organização estabelece reputação e pode criar demanda. Se a organização é atualmente reconhecida no setor por um alto nível de qualidade, pode haver preocupação por parte dos tomadores de decisão ou clientes de que a terceirização da atividade possa prejudicar a qualidade. De forma contrária, se a empresa independente for quem tiver boa reputação e performance igual ou melhor que a empresa contratante, a decisão pela terceirização é positiva (Kremic et al., 2006).

Além de reorientar os recursos para as competências essenciais, outras questões estratégicas que podem incentivar a terceirização são: a reestruturação, o rápido crescimento organizacional, a mudança de tecnologia e a necessidade de maior flexibilidade. A terceirização também pode ser percebida como uma maneira de reduzir o risco da organização, compartilhando-o com os fornecedores e, ao mesmo tempo, adquirindo os atributos positivos desses fornecedores. Há, no entanto, potenciais armadilhas quando a terceirização para razões estratégicas. As organizações podem 'dar as joias da coroa' se não tiverem cuidado. $\mathrm{O}$ fator de conhecimento crítico também é uma questão estratégica e, em geral, se uma atividade fornecer esse tipo de conhecimento, é menos provável que ela seja terceirizada. A literatura também indica que, em indústrias com tecnologias e sistemas complexos, sinergias internas podem ser perdidas quando algumas funções são terceirizadas, podendo resultar, segundo pesquisa de Quinn e Hilmer (1994), em menor produtividade ou eficiência entre as funções remanescentes (Kremic et al., 2006).

O Quadro 5, na página seguinte, sintetiza alguns benefícios esperados e alguns riscos percebidos na terceirização de atividades anteriormente citados. 
Quadro 5: Benefícios esperados e riscos potenciais da terceirização

\begin{tabular}{|l|l|}
\hline \multicolumn{1}{|c|}{ Benefícios esperados } & \multicolumn{1}{c|}{ Riscos potenciais } \\
\hline Economia de Custos & Economia não realizada ou custos ocultos \\
\hline Despesas de capital reduzidos & Menor flexibilidade \\
\hline Infusão de capital & Contrato ruim ou má seleção de parceiro \\
\hline Transferir custos fixos para variáveis & Conhecimento corporativo perdido \\
\hline Melhoria da qualidade & Perda de controle / competência essencial \\
\hline Rapidez & Transferência de poder para fornecedor \\
\hline Aumento flexibilidade & $\begin{array}{l}\text { Problemas com fornecedores (mau desempenho ou } \\
\text { relações ruins, comportamento oportunista) }\end{array}$ \\
\hline Acesso à tecnologia/infraestrutura moderna & Perder clientes, oportunidades ou reputação \\
\hline Acesso a habilidades e talentos & Incerteza / mudança de ambiente \\
\hline Aumento de colaboradores & Problemas de moral dos funcionários \\
\hline Aumentar o foco nas atividades principais & Perda de sinergia \\
\hline Terceirizar atividades problemáticas & Conflito de interesses \\
\hline Copiar concorrentes & Problemas de segurança \\
\hline Maior compliance & Falsa sensação de irresponsabilidade \\
\hline Melhor gestão e prestação de contas & Obstáculos legais \\
\hline & Erosão habilidade na empresa \\
\hline
\end{tabular}

Fonte: Kremic et al. (2006), adaptado pela autora

\subsubsection{Sintese estruturas de governança}

Coase (1937) foi questionado por Cheung (1983): se o dono de um pomar contratasse um apicultor para polinizar suas frutas o resultado seria uma ou duas firmas? Cheung (1983) chega à conclusão que essa pergunta não tem uma resposta clara. $\mathrm{O}$ contrato poderia ser de aluguel da colmeia, um pagamento de salário para a colmeia, um contrato de parceria da produção de macas, ou ainda uma combinação destes e outros arranjos. Em cada caso, o apicultor receberia uma remuneração pelo seu serviço, e as ordens que ele receberia do dono do pomar variariam de acordo com o formato do contrato. Um agente tributário poderia tratar o apicultor e o dono do pomar como uma ou duas empresas, dependendo das leis de impostos e das regras adotadas na região. Do ponto de vista econômico, Cheung (1983) aponta que a maioria dos economistas optaria por uma empresa se o apicultor for contratado baseado em um salário, mas duas empresas se as colmeias fossem alugadas.

Os questionamentos de Cheung (1983) a respeito do número ou tamanho das empresas e das formas de contrato escolhidas sugerem que a firma, de acordo com o ponto de vista, pode ser tão pequena quanto uma relação contratual entre dois proprietários de insumos, ou se a cadeia de contratos puder ser ampliada, pode ser tão grande quanto toda a economia. 
Sendo assim, Cheung (1983) afirma que é inútil focar na questão do que é ou não uma empresa e as questões importantes são: por que os contratos assumem as formas observadas e quais são as implicações econômicas de diferentes arranjos contratuais? Esse é o objetivo desta tese, ao incluir o ambiente institucional na análise, para então tentar responder à algumas dessas questões.

Os dois frameworks apresentados, a ECT e a arquitetura organizacional, têm no valor da transação para as partes e na incerteza, atributos importantes na definição do desenho do acordo e da estrutura de governança da firma. Existem inúmeras vantagens, na literatura econômica e de gestão, para recorrer aos contratos com empresas especializadas e independentes, bem como há riscos associados.

As transações comparadas na pesquisa são semelhantes em especificidade do ativo, valor criado e frequência para as partes. Logo, a variável incerteza no ambiente institucional, especificamente o sistema judiciário, que a transação está inserida, será explorada com mais profundidade.

O Quadro 6 sumariza os atributos da transação na ECT e os atributos do acordo na arquitetura organizacional, referencial teórico utilizado para analisar as estruturas de governança das empresas do agronegócio.

Quadro 6 Atributos da transação na ECT e atributos do acordo na Arquitetura Organizacional

\begin{tabular}{|c|c|c|}
\cline { 2 - 3 } \multicolumn{1}{c|}{} & \multicolumn{2}{|c|}{ REFERENCIAL TEÓRICO } \\
\cline { 2 - 3 } & Economia Custos Transação & Arquitetura Organizacional \\
\hline \multirow{2}{*}{ Atributos } & Especificidade do ativo & Valor criado pela transação \\
\cline { 2 - 3 } & Incerteza & Incerteza \\
\cline { 2 - 3 } & Frequência & Direitos de Decisão \\
\hline Estrutura de & Alinhamento dos direitos de & Alinhamento do acordo \\
\hline governança & propriedade & \\
\hline
\end{tabular}

Fonte: elaborado pela autora (2018) 


\subsection{AMBIENTE INSTITUCIONAL}

\subsubsection{Ambiente Institucional e Instituições.}

Na Nova Economia Institucional, a firma, empresa ou organização é vista como um nexo de contratos, formais e informais, e, portanto, é afetada pelo aparato legal que cerca as transações na transferência dos direitos de propriedade e decisão dos bens e serviços transacionados. Esse aparato em que as transações estão inseridas é o ambiente institucional. As instituições formam a estrutura de incentivos de uma sociedade e, com a política econômica, são fatores determinantes do desempenho econômico de uma nação (North, 1991).

As instituições, de acordo com North (1991), são as restrições concebidas pelos homens que estruturam a interação política, econômica e social. Elas consistem em restrições informais (sanções, tabus, costumes, tradições e códigos de conduta) e regras formais (constituições, leis, direitos de propriedade). As instituições foram criadas com o intuito de criar ordem e reduzir a incerteza nas transações; e com as restrições padrões da economia, definem o conjunto de escolhas. Por conseguinte, determinam os custos de transação e produção e, logo, a lucratividade e a viabilidade de se engajar na atividade econômica. As instituições emergem, portanto, para reduzir a incerteza ao estruturar as interações humanas.

A incerteza é presente em três dimensões de acordo com North (1999): i) em uma, o ser humano tem de adquirir mais informação e conhecimento para ser capaz de reduzir a incerteza para risco; ii) na segunda, envolvendo os aspectos não-ergódicos ${ }^{7}$ dos sistemas nos quais se está interessado, quando se tem muito menos certeza de que o ser humano resolverá os problemas com os quais se preocupa; iii) na terceira dimensão, o indivíduo fica 'empacado' (bloqueado) sem uma teoria dinâmica da mudança.

O termo instituições é amplamente utilizado e pode inclusive denominar as organizações, também conhecidas como arranjos institucionais, ou seja, a forma como se organizam e se estruturam. Entretanto, para fins de homogeneidade e clareza, considera-se na presente tese o termo 'instituições' para os agentes que fazem parte do ambiente institucional,

\footnotetext{
7 Em sistemas ergódicos, a realidade externa é imutável. Do ponto de vista metodológico, a hipótese ergódica fundamenta a economia neoclássica. Em processos não ergódicos, a realidade é criativa. Decisões cruciais geram ambientes não ergódicos, incertos, em que o tempo é irreversível. Em um sistema não ergódico, a realidade externa é "transmutável ou criativa no sentido de que o futuro econômico pode ser criado por ações humanas correntes e futuras" (Davidson (1995), citado em Andrade, 2011).
} 
que formam as regras formais e informais, leis, costumes, sistemas legais, econômico e político em que ocorrem as transações. As estruturas de governança das empresas serão designadas como organizações, assim como fez Douglas North (1991, 1994, 1999, 2005).

A tomada de decisão, no ponto de vista de North (1999), é uma combinação de escolhas racionais pretendidas, suplementadas por instituições eficazes que limitam o ambiente e as incertezas do ambiente e da estrutura artefactual. O que o autor chama de “estrutura artefactual” é o conjunto de instituições, ferramentas e técnicas que os humanos criam quando lidam com o mundo ao seu redor.

Quando o ambiente é estruturado por regras, leis, ferramentas e técnicas, as decisões disponíveis são limitadas em certas direções. São essas restrições que ajudam o tomador de decisões, aumentando a previsibilidade dos resultados ao diminuírem as opções aceitáveis. Quanto mais incompreensível o ambiente, por falta de uma estrutura artefactual efetiva, mais difícil se torna para as pessoas fazerem escolhas ou implementá-las de maneira eficaz.

No entanto, não somente uma estrutura artefactual é levada em consideração, o grau de identidade entre as restrições institucionais vigentes e as escolhas e ações dos indivíduos nesse ambiente institucional dependem também da eficácia do enforcement. O enforcement refere-se à eficácia em que se fazem valer as escolhas, acordos e restrições.

O enforcement, na visão de North (1992), é outra variável importante. Em um mundo com o enforcement perfeito, haveria uma terceira parte imparcial (e sem custos) avaliando disputas e concedendo compensação à parte lesada quando os contratos fossem violados. Em tal mundo, o oportunismo, esquivar-se do compromisso e trapacear, nunca valeriam a pena. Contudo, tal mundo não existe. De fato, a dificuldade de criar um sistema judiciário relativamente imparcial que faz valer os acordos tem sido um obstáculo crítico no caminho do desenvolvimento econômico. No mundo ocidental, a evolução dos tribunais, dos sistemas jurídicos e de um sistema relativamente imparcial de execução judicial desempenha um papel importante em coibir problemas de oportunismo e hold up, permitindo, dessa maneira, o desenvolvimento de um sistema complexo de contratação que pode se estender ao longo do tempo e espaço, um requisito essencial para a especialização econômica.

Ao acrescentar mais um ponto sobre o enforcement North (1999) aponta que não é o objetivo que a imposição seja perfeita (porque os ganhos e custos marginais são assimétricos em relação à maneira como eles evoluem). Tipicamente, a pessoa quer uma fiscalização suficiente para resolver os problemas em questão, ou pelo menos para perceber e lidar com os problemas, no entanto significa que o enforcement é imperfeito. 
Os custos de transação determinantes da estrutura de governança das organizações são influenciados diretamente pelo ambiente institucional em que elas estão inseridas. Allen (2000) sustenta que os custos de transação também são conhecidos como os custos de estabelecer, manter e transferir os direitos de propriedades. Estes são refletidos na busca por preços, parceiros comerciais, barganhas, escrita de contratos, enforcement de contratos, monitoramento e proteção de direitos de propriedade. Além de explicar a existência da firma, Coase (1960) aponta que os custos de transação também explicam a existência das leis.

A abordagem de custos de transação na NEI tem os conceitos de direitos de propriedade e custos de transação fundamentalmente interligados. Quando uma transação é concluída no mercado, dois pacotes de direito de propriedades são transacionados segundo Demsetz (1967). Um conjunto de direitos geralmente é atribuído a uma mercadoria ou serviço, mas é o valor dos direitos que determina o valor do que é transacionado e criado.

A visão de Alchian (1965) é de que o conjunto de regras que garantem a distribuição dos direitos de propriedade determina o nível de produção da empresa porque determinam os incentivos de cada indivíduo de produzir.

Posteriormente, na definição do direito de propriedade, Alchian e Demsetz (1973) sugerem três perguntas para este tema: (1) Qual é a estrutura dos direitos de propriedade em uma sociedade em algum ponto do tempo? (2) que consequências para a interação social fluem de uma estrutura particular de direitos de propriedade? (3) e como esta estrutura de propriedade surgiu? Questões essas que são discutidas quando o paradigma da integração vertical é discutido.

A escolha pela estrutura de governança que melhor se adequa a determinada situação não é somente uma escolha que se refere à posse de um recurso ou à contratação de um serviço para a empresa, esse discurso habitual mascara a variedade e a complexidade da relação de propriedade que Alchian e Demsetz (1973) propõem. O que é possuído na verdade são os direitos de utilizar o recurso, direitos de ação sobre o recurso que são socialmente reconhecidos. Assim como não é o recurso em si que é possuído, mas sim seus direitos de uso e decisão sobre ele, Alchian e Demsetz (1973) também apontam que esses direitos podem ser particionados entre várias pessoas e podem ser transacionados também por meio de contratos, não somente mediante a propriedade do bem.

A estrutura de direitos de propriedade apresenta importantes consequências para a alocação de recursos, porque, de fato, esses direitos de propriedade não são transferidos entre as partes sem custos, então a questão relevante é quais os direitos mais apropriados para a empresa possuir inicialmente. 
Além dos custos de transacionar os direitos de propriedade, existe o custo de medir os atributos valiosos dos bens e serviços ou o desempenho dos agentes que, segundo Douglas North (1992) é chave fundamental para o custo de transacionar. São necessários recursos para medir esses atributos e para definir e medir os direitos de propriedade que são transferidos na transação. A mensuração envolve definir não apenas as dimensões físicas dos atributos trocados (cor, tamanho, peso, número etc.), mas também as dimensões dos direitos de propriedade da transação (direito de uso, da renda a ser derivada e alienação). Como esses custos são altos e por vezes imprevisíveis, os direitos são especificados de forma imperfeita e incompleta.

Por fim, North (1992) destaca que a ideologia; que são 'modelos' subjetivos que os indivíduos empregam para explicar e avaliar o mundo ao seu redor; não apenas desempenha um papel essencial nas escolhas políticas, mas também é uma chave para as escolhas individuais que afetam o desempenho econômico. Ele considera que as percepções individuais sobre a imparcialidade das regras do jogo obviamente afetam o desempenho, visto que a mensuração e o enforcement dos contratos costumam ser dispendiosos no processo de troca.

A maneira como um sistema econômico é organizado determina a distribuição dos benefícios; porém, a operação e organização de um sistema econômico não ocorrem sem custos, aponta North (1992). Contudo, é do interesse dos participantes organizarem o sistema de modo a se beneficiarem. Mesmo que, ao fazê-lo, não haja garantia de que a estrutura institucional resultante necessariamente se converta no crescimento econômico esperado.

Os mercados eficientes, do ponto de vista de North (1992), são uma consequência de instituições que proporcionam mensuração de baixo custo e enforcement de contratos. Instituições que fornecem flexibilidade econômica e política para se adaptarem a novas oportunidades são essenciais para a eficiência ao longo do tempo. Tais instituições 'adaptativamente' eficientes devem fornecer incentivos para a aquisição de conhecimento e aprendizado, induzir a inovação e incentivar a tomada de risco e a atividade criativa. Hayek (1945), como citado em North (1992) salienta que em um mundo de incertezas, ninguém sabe a solução correta para os problemas que são enfrentados. Portanto, as instituições devem encorajar tentativas e eliminar erros.

Douglas North (1999, p. 8) deixa suas impressões quando visita países de terceiro mundo "me preocupo com a tentativa de implementar mudanças políticas para obter um melhor desempenho. É fato que as escolhas feitas nesses contextos, onde não há uma estrutura artefactual efetiva, levam a decisões ruins.” 


\subsubsection{Evolução do Ambiente Institucional}

É a interação entre as instituições e organizações que molda a evolução institucional de uma economia. Se as instituições são as regras do jogo, as organizações e seus empresários são os jogadores. Dessa interação e da evolução das instituições políticas e econômicas que surgem ambientes econômicos propícios que induzem ao aumento da produtividade e crescimento econômico sustentável (North, 1994).

$\mathrm{O}$ autor ainda destaca que a questão central da história econômica e do desenvolvimento econômico é contabilizar a evolução das instituições políticas e econômicas que criam um ambiente que induz o aumento de produtividade. North diz que "isso explica a performance variada das economias, tanto ao longo do tempo quanto no mundo atual" (North, 1991, p. 98).

A questão é que essas instituições levam tempo para evoluir e apresentar mudanças que podem ser notadas no desenvolvimento e aumento da produtividade de um determinado país. Em uma análise dos quatro níveis sociais, Williamson (2000) apresenta-se, na página seguinte, a Figura 10, destacando que a NEI se preocupa mais com os níveis 2 e 3, que serão os níveis abordados na pesquisa. 
Figura 10: Economia das Instituições

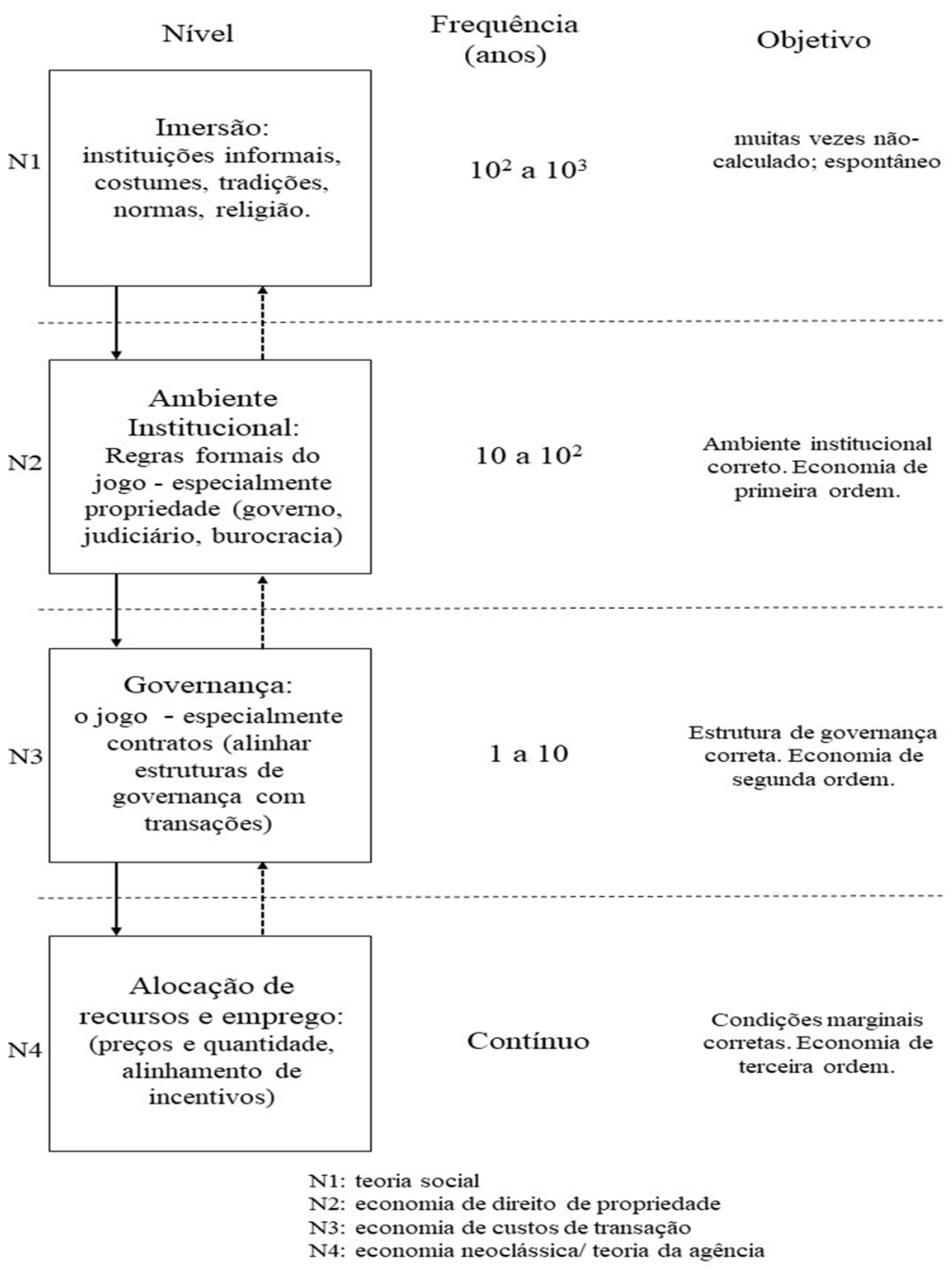

Fonte: Williamson (2000, p. 597) - tradução livre, elaborada pela autora desta pesquisa

O nível superior abordado na análise social de (Williamson, 2000) é o nível da imersão social (embeddedness). De acordo com North (1992), as mudanças institucionais resultantes de mudanças em restrições informais - normas, costumes, tradições, ou padrões pessoais de honestidade, por exemplo - ocorrerem de forma muito gradual e às vezes bastante subconsciente, conforme os indivíduos evoluem seus padrões de comportamento consistentes com a sua avaliação de custos e benefícios.

O nível 1 é considerado como dado pela maioria dos economistas institucionais. Nesse nível, as instituições mudam muito lentamente - na ordem de séculos ou milênios. North (1991), inclusive, questiona sobre o que há com as restrições informais que lhes dão uma influência tão difundida sobre o caráter de longo prazo das economias. Uma identificação e a explicação dos mecanismos pelos quais as instituições informais surgem e são mantidas 
ajudariam especialmente a entender a lenta mudança nas instituições de Nível 1 segundo Williamson (2000).

O segundo nível que Williamson (2000) descreve é referido como o ambiente institucional. As estruturas observadas aqui são, em parte, o produto de processos evolutivos.

Nesse nível 2 são introduzidas as "regras formais (constituições, leis, direitos de propriedade)" (North, 1991, p. 97). O segundo nível é onde ocorrem as oportunidades para a economia de primeira ordem: estipular as regras formais do jogo. A configuração do Nível 2 inclui as funções executivas, legislativas, judiciais e burocráticas do governo, bem como a distribuição de poderes entre diferentes níveis de governo. A definição e aplicação dos direitos de propriedade e das leis contratuais são características importantes. Embora tais escolhas de primeira ordem sejam importantes para a produtividade econômica, as mudanças cumulativas neste nível são muito difíceis de orquestrar. Mudanças nas regras do jogo, ausentes janelas abruptas de descontentamento que levam a reformas, ocorrem na ordem de décadas e séculos.

Mudanças nas regras formais incluem mudanças legislativas, como a aprovação de um novo estatuto; mudanças judiciais resultantes de decisões judiciais alterando o direito comum (common law nos Estados Unidos); mudanças nas regras regulatórias aprovadas pelas agências reguladoras; e mudanças de regras constitucionais, que alteram as regras (North, 1992).

A economia dos direitos de propriedade acontece no nível 2. O argumento de Coase (1959), como citado em Williamson (2000), é que um sistema de empresa privada não pode funcionar adequadamente, a menos que direitos de propriedade sejam criados e garantidos ao proprietário; o resultado da criação e da garantia desses direitos de propriedade é o desaparecimento do caos e do governo, mantendo-se apenas um sistema legal para definir direitos de propriedade e arbitrar disputas. Todavia, a alegação, por exemplo, de que o sistema jurídico eliminará o caos ao definir e fazer cumprir os direitos de propriedade pressupõe que a definição e o cumprimento de tais direitos sejam fáceis e sem custos. Para além das regras do jogo (direito de propriedade), é necessário incluir a documentação do jogo (contrato).

Do ponto de vista de North (1992), mesmo que as regras formais possam mudar rapidamente com algum decreto, as restrições informais não as acompanham. Inconsistências entre as regras formais e as restrições informais (que podem ser o resultado de uma herança cultural arraigada) resultam em tensões tipicamente resolvidas por uma reestruturação das restrições gerais, em ambas as direções, para produzir um novo equilíbrio que acomode as regras formais e informais. 
Segue-se então para o terceiro nível no esquema de Williamson (2000), que é onde as organizações, também conhecidas como empresas e firmas, e suas estruturas de governança estão localizadas. Embora a propriedade permaneça importante, um sistema legal que funcione perfeitamente para a definição de leis e execução de contratos não é contemplado neste nível. Uma vez que não existe ordenação judicial gratuita, grande parte da gestão de contratos e da ação de solução de controvérsias é, portanto, tratada diretamente pelas partes envolvidas. Nesse nível, a governança das relações contratuais torna-se o foco da análise. A economia dos custos de transação não apenas adere à ideia de que a transação é a unidade básica de análise, mas defende também que a governança é um esforço para elaborar a ordem, mitigando assim o conflito e realizando ganhos mútuos. Assim concebida, uma estrutura de governança obviamente reformula os incentivos.

A questão apresentada por Williamson (2000) nesse nível é o da integração vertical, paradigma apresentado por Coase em seu artigo de 1937 sobre A natureza da firma. Como se constata, qualquer questão que surja ou possa ser reformulada como uma questão de contratação pode ser examinada com vantagem, em termos de economia de custo de transação. O que é chamado de economia de segunda ordem para obter as estruturas de governanças corretas é percebido no Nível 3. A possível reorganização das transações entre estruturas de governança é reexaminada periodicamente, na ordem de um ano a uma década, na renovação de contrato ou em intervalos de renovação de equipamento.

Tal análise estrutural discreta da governança deve ser distinguida do quarto nível, que é o nível no qual a análise neoclássica funciona. No nível 4, o aparato de otimização, frequentemente a análise marginal, é empregado, e a empresa, para esses propósitos, é tipicamente descrita como uma função de produção. Ajustes nos preços e na produção ocorrem mais ou menos continuamente (Williamson, 2000).

\subsubsection{Ambiente Institucional: Estado de Direito e Sistema judiciário /Legal}

Uma característica geral da história humana, de acordo com North (2005), tem sido a redução sistemática na incerteza percebida associada ao ambiente físico. Contudo, se a incerteza associada ao ambiente físico diminuiu, uma consequência tem sido um ambiente humano muito mais complexo. Ao longo do tempo, os humanos alteraram o ambiente para torná-lo menos incerto, consequentemente mais previsível. 
A alteração do framework institucional implica a mudança da estrutura de incentivos, e tem sido uma condição essencial para a redução das incertezas do ambiente institucional ao longo do tempo. Esta tem sido a principal ferramenta pela qual os humanos têm tentado deliberadamente alterar seu ambiente. Essas alterações abrangem muitos dos esforços no mundo contemporâneo para melhorar o desempenho das economias do terceiro mundo. Historicamente, a mudança institucional alterou o pay-off (recompensa) da atividade cooperativa (a execução legal de contratos, por exemplo), aumentou o incentivo para inventar e inovar (leis de patentes), alterou o retorno para investir em capital humano (o desenvolvimento de instituições para integrar o conhecimento distribuído de economias complexas) e reduziu os custos de transação nos mercados (a criação de um sistema judiciário que reduz os custos de execução de contratos). (North, 2005, p. 18).

Os direitos de propriedade são especificados e aplicados pelas políticas vigentes e, sem uma compreensão profunda das formas como as políticas evoluem, não é possível compreender como os direitos de propriedade evoluem e são assegurados, afirma North (1994).

As regras formais são uma parte importante do quadro institucional para North (1994) e mudanças nessas regras formais (e fiscalização) acontecem por meio da política (abrangendo amplamente os ramos judiciário, executivo e legislativo). Consequentemente, o crescimento econômico bem-sucedido está historicamente vinculado à evolução do governo representativo e garantia dos direitos de propriedade com o Estado de Direito.

O Estado de Direito exige que as leis sejam adotadas de acordo com os procedimentos estabelecidos, que sejam divulgadas ao público e que sejam cumpridas de forma consistente e imparcial. O Estado de Direito tem a intenção de garantir que o governo exerça sua autoridade de forma justa, e é crucial para garantir a liberdade e a justiça para o povo de qualquer nação. North (1999) nota que nenhum país é perfeito a este respeito, mas alguns se saem melhores que os outros ao desempenharem tais funções.

A área de estudos do direito e economia, por alguns autores referida como economia do direito, traz diversas áreas que associam o Ambiente Institucional e o Estado de Direito (rule of law) ao desempenho econômico. Seja no ambiente econômico ou nas transações, o ambiente institucional de um país exerce influência no seu desempenho econômico. São as instituições que delimitam e garantem os direitos de propriedades, que dão enforcement aos contratos, e que possibilitam que as organizações e indivíduos realizem as trocas; logo, o bom funcionamento delas tem como resultado o bom desempenho da nação.

A definição dos direitos de propriedade particulares, além de dar garantia às partes enquanto estão transacionando, permite que eles possam ser fiscalizados mais facilmente e mitiga o incentivo das pessoas esgotarem os recursos, o que aconteceria se estes fossem públicos e compartilhados por todos. Em Property Rights Paradigm, Alchian e Demsetz 
(1973) destacam a importância de definir corretamente os direitos de propriedade particulares mediante alguns exemplos clássicos da falta dessa definição, como no caso das peles exploradas pelos índios no Novo Continente, ou a caça atroz dos filhotes de focas por causa de uma regulamentação equivocada que definia a isenção de impostos para os primeiros animais capturados, o que acabava incentivando o abate desumano decorrente da pressa dos caçadores para obterem a isenção.

O tema do Direito e Economia é desenvolvido por diversos autores. Leeson e Suarez (2016), por exemplo, elaboram a abordagem econômica das constituições, em que sugerem algumas condições necessárias na constituição para que a autoridade dos governantes seja limitada e para que a constituição seja self-enforcing, ou seja, que a lei seja efetivamente cumprida. Uma 'constituição' para esse propósito refere-se a qualquer acordo entre os governantes políticos e seus cidadãos, contendo promessas relacionadas com o objetivo de circunscrever a autoridade de governança do primeiro - isto é, estabelecendo restrições governamentais. As condições identificadas como necessárias são três: (i) a primeira é a condição de ser pública e clara, uma constituição deve estabelecer publicamente limites suficientemente claros sobre a autoridade do governo; (ii) a segunda condição necessária é a condição dos benefícios mútuos, deve refletir trocas mutuamente benéficas entre os governantes e os cidadãos que os contratam; (iii) a condição final necessária é a de inclusividade, isto é, deve promover os interesses dos diversos grupos de cidadãos.

A literatura sobre o Estado de Direito e o crescimento econômico tornou-se uma das áreas mais dinâmicas do trabalho teórico e empírico em ciência política, economia e direito. Existe uma teoria que traz diferentes mecanismos causais que ligam o Estado de Direito, o rule of the law, ao crescimento econômico. Revisada por Haggard e Tiede (2011), essa teoria aponta quatro mecanismos que promovem essa união, são eles: 1) provisão de segurança das pessoas; 2) mediante a segurança da propriedade e execução dos contratos; 3) pelas verificações no governo (é necessário que haja limites efetivos ao poder do executivo); e 4) por meio de controles da corrupção.

O principal mecanismo teórico, segundo os economistas, que liga a lei ao desenvolvimento econômico passa pelos direitos de propriedade e pela execução de contratos. A ligação dos direitos de propriedade ao crescimento, segundo Haggard e Tiede (2011), é executada por meio dos incentivos que os indivíduos têm de investir e comercializar quando esses direitos são seguros. A capacidade de contratar é igualmente fundamental. Algumas trocas comerciais podem ter lugar sob a forma de permutas ou trocas spot (no mercado), mas as transações intertemporais mais complexas, incluindo as financeiras e as parcerias, exigem a 
capacidade de fazer e receber promessas sobre ações futuras como visto em Djankov, LaPorta, Lopez-de-Silanes, e Shleifer (2002). .

O trabalho empírico denominado The rule of the law and Economic Growth: Where we are, de Haggard e Tiede (2011), relaciona evidências dos mecanismos institucionais em alguns países com possíveis diferenças no desenvolvimento econômico. O artigo agrupa em clusters os países, de acordo com 11 indicadores do Estado de Direito para corresponder a quatro mecanismos causais identificados. São encontradas diferenças entre os indicadores do Estado de Direito para países em estado industrial avançado e entre os países em desenvolvimento, sendo que os indicadores do Estado de Direito nos primeiros são maiores do que os encontrados entre os países em desenvolvimento. Adicionalmente, na análise de clusters é sugerida fortemente a presença de diferentes 'complexos' ou 'síndromes' do Estado de Direito em países em desenvolvimento. O que distingue esses complexos não são os arranjos institucionais formais, mas a corrupção, o risco de expropriação e particularmente a extensão da violência. Esses achados sugerem um programa de pesquisa que enfoca mais atenção nas complementaridades entre instituições de Estado de Direito: como as múltiplas dimensões do Estado de Direito operam para promover ou retardar o crescimento econômico.

Caminhando um pouco para os efeitos institucionais dentro das empresas, Saona e San Martín (2016) seguem uma abordagem de governança corporativa, avaliando a possibilidade de prever mudanças nas empresas latino-americanas com informações das mudanças dos sistemas legais e regulatórios do país, como também das mudanças na concentração de propriedade corporativa. Usando modelos de dados de painel de efeito fixo com uma amostra representativa de firmas para o período de 1997 a 2013, eles observaram que os direitos dos investidores e sua proteção legal, bem como o Estado de Direito, são associados a um prêmio no valor de mercado das empresas. Essa descoberta indica que os órgãos legais que exigem a divulgação de informações, o enforcement por meio de regras de responsabilidade, e que fornecem um governo eficiente associado a maior qualidade regulatória beneficiam significativamente o valor das empresas.

O sistema legal e o regulatório, nas hipóteses levantadas por Saona e San Martín (2016), envolvem uma série de dimensões, tais como: (a) a origem do sistema jurídico, que define criticamente a maneira de se comportar e compreender a vida na sociedade; (b) a medida em que os cidadãos de um país podem participar na seleção de seu governo, bem como a liberdade de expressão, associação e mídia; c) a proteção geral dos direitos de propriedade (nomeadamente os dos credores e dos acionistas), que garante os participantes nos mercados financeiros; d) o enforcement (aplicação da lei); (e) a corrupção, que parece ser 
um problema endêmico na América Latina; e (f) transparência e divulgação de informações corporativas, entre outros. No que se refere às variáveis que medem o impacto sobre o valor da empresa causado pelo sistema jurídico e regulatório, é observado que todas, exceto a estabilidade política e o controle da corrupção, mostram um coeficiente fortemente positivo e estatisticamente significativo.

North (2005) aponta que a teoria econômica neoclássica fez pouco para promover a compreensão de assuntos como a importância dos tribunais e de como são centrais para o desempenho econômico. $\mathrm{O}$ autor, que é precursor na área de direito e economia, oferece uma construção teórica para medir a perda econômica resultante de fraquezas institucionais, incluindo um sistema judiciário fraco. Ele esclarece que, à medida que a economia mundial torna-se mais integrada, a competição entre as nações será ganha por aqueles com melhores instituições. Essas instituições promovem soluções para o problema do desempenho econômico pela tomada de decisão descentralizada e recompensa a aquisição de habilidades e conhecimentos produtivos. North (2005) aponta as novas tecnologias como a força motriz no desempenho econômico e diz que as melhores instituições (regras do jogo) serão aquelas que criam organizações (jogadores) que aplicam essas novas tecnologias para melhorar soluções para alcançar o crescimento econômico. Ele observa especificamente a importância de direitos de propriedade bem especificados e aplicados (enforced).

\subsubsection{Sistemas judiciais e economia da eficiência}

Os sistemas judiciais podem ser importantes para a economia por uma variedade de razões, eles fazem parte das instituições formais de um país. Vários intelectuais (Acemoglu, Johnson, \& Robinson, 2001; Alchian \& Demsetz, 1973; Almeida \& Zylbersztajn, 2012; Azevedo \& Silva, 2007; Bednar, 2004; Borner, Brunetti, \& Weder, 1992; Castelar, 2009; Cooter \& Ulen, 2016; Cross \& Donelson, 2010; Djankov et al., 2002; Haggard \& Tiede, 2011; Hall \& Jones, 1999; La Porta, Lopez-De-Silanes, Shleifer, \& Vishny, 1997; LaPorta et al., 1998; North, 1991; Rezende \& Zylbersztajn, 2012, 2012; Sanches \& Bataglia, 2015; Sztajn \& Zylbersztajn, 2005; Timm, 2009; Wang et al., 2014; Woodruff, 2006) examinaram o efeito das instituições e dos sistemas jurídicos sobre o crescimento econômico ou outras medidas de bem-estar humano. Além de demonstrar a importância das instituições no desenvolvimento econômico das nações ao longo do tempo, Douglas North (1981) enfatiza a importância da proteção dos direitos de propriedade, mas também observa como o Estado 
pode reduzir o custo das transações por meio do "desenvolvimento de um corpo impessoal de lei e seu enforcement, bem como destaca que a criação de um sistema judiciário efetivo é uma das chaves para melhorar a performance econômica" (North, 2005, p. 159).

Outros autores inspiraram-se na compreensão da importância das instituições e aprofundaram os estudos no papel dos sistemas judiciais no desenvolvimento econômico e das empresas. Ramello e Voigt (2012) afirmaram que um país somente se desenvolve com a presença de um judiciário eficaz em que as promessas do governo de enforcement dos direitos de propriedade privados são críveis para potenciais investidores. Somente se o judiciário é encarregado da lei e não é corruptível pelas partes interessadas é que faz sentido realizar transações por meio de contratos. Apenas se o judiciário for acessível a potenciais demandantes é que ele pode ser visto como um verdadeiro protetor de seus direitos formais; e somente se for eficiente não haverá grandes atrasos nas decisões judiciais. Finalmente, apenas um judiciário que funcione adequadamente pode interagir com sucesso com o legislativo e o executivo, como é necessário para que eles consigam conjuntamente resultados social e economicamente valiosos.

De acordo com Cross e Donelson (2010), existe um consenso de que a qualidade do sistema judiciário é de grande importância para o sucesso econômico de uma sociedade; no entanto, os componentes precisos da qualidade do sistema judiciário não são bem especificados. Alguns atributos que são importantes: i) a independência do judiciário, pois não se pode confiar em um judiciário dependente para fazer julgamentos legais; ii) a acessibilidade do sistema judiciário; iii) a eficiência e eficácia, uma vez que o sistema judiciário teria menor valor se as decisões fossem prematuras e inoportunas ou se não fossem efetivamente aplicadas.

É válido tentar criar regras que funcionem, segundo (Martinez, 2003), porque um sistema funcional para resolver disputas serve a muitos valores, entre eles previsibilidade, justiça, facilidade de interação comercial e estabilidade por meio da satisfação de expectativas mútuas, valores de um sistema judiciário que são citados por diversos autores.

Segundo Bednar (2004), a literatura formal sobre tribunais - como a das instituições em geral - antigamente pressupunha que essas instituições adjudicatórias eram infalíveis e desinteressadas (ou seja, não tem utilidade em resoluções individuais) e, por conseguinte, a reação do tribunal seria previsível (predictability). No entanto, em estudos mais aplicados, os críticos muitas vezes questionam a conveniência de confiar no tribunal que pode estar fora de sintonia ou tendencioso, que pode resultar em comportamento oportunista dos agentes e prejuízo no ambiente de negócios. Portanto, Bednar (2004) enfatiza que mudanças na 
instituição alteram o grau de previsibilidade, por vezes melhorando, por reforma legal ou recursos adicionais, outras vezes diminuindo a previsibilidade.

Alguns autores da área de Direito e Economia estudaram especificamente a situação da América Latina, trazendo alguns bons insights dos sistemas judiciais na região e do impacto no desempenho econômico. Sob um regime de liberalização econômica, novos padrões de atividade emergem e mais transações são experimentadas, muitas delas impessoais como relatam (Sherwood et al., 1994). À medida que novas transações com padrões diferentes ocorrem, choques entre os interesses privados são esperados. Nessas novas configurações, as partes privadas precisam testar os limites de suas posições. Embora o Estado seja menos ativo em conduzir uma atividade econômica, ele é chamado para apoiar o interesse público como um regulador ou árbitro, o que leva a novos tipos de disputas entre interesses privados e órgãos reguladores governamentais.

À proporção que os economistas estudam o papel das instituições no desenvolvimento econômico, (Sherwood et al. (1994) destacam que começam a colocar mais ênfase na estabilidade e credibilidade que um Estado de Direito eficaz contribui para o desempenho econômico. Um sistema judiciário que funcione bem fornece um mecanismo importante para o controle do poder de decisão, ou pelo menos, evita o abuso de poder na medida em que possa violar direitos privados adquiridos.

A falta de confiabilidade judicial, segundo pesquisas de Borner et al. (1992), custa muito a um país em termos de crescimento econômico. Esse custo é largamente invisível. Em trabalho posterior, Brunetti e Weder (1994) mostram uma alta correlação entre crescimento econômico e credibilidade judicial.

Buscaglia e Ulen (1997) também pesquisaram evidências na América Latina, eles avaliaram quantitativamente a eficiência do judiciário na América Latina, região que é conhecida por um judiciário incapaz de fomentar o desenvolvimento do setor privado em um sistema de mercado, devido aos tribunais sobrecarregados e incapazes de dispor dos casos em tempo oportuno. Como resultado, litigantes frustrados perdem a fé na capacidade do sistema de justiça público para resolver suas disputas. Dessa forma, as partes privadas consideram os custos adicionais do atraso judicial em suas transações privadas, e esses custos adicionais reduzem a atividade econômica e retardam o desenvolvimento econômico.

Em muitos dos sistemas judiciais da América Latina falta estabilidade: as leis não são claras, e a forma como os tribunais aplicam as leis é altamente incerta e imprevisível. Como não existem mecanismos viáveis de resolução de litígios alternativos na maioria dos países latino-americanos, o diagnóstico de Buscaglia e Ulen (1997) é que a região necessita de um 
setor judicial eficiente para complementar as reformas de mercado que foram introduzidas nos governos da região.

Como resultado da ausência de um judiciário imparcial e eficiente ou mecanismos alternativos de resolução de litígios, Buscaglia e Ulen (1997) citam que as partes privadas tendem a confiar na reputação, nas relações familiares e nas transações recorrentes com agentes de confiança. Dispositivos esses que excluem muitas transações potencialmente benéficas socialmente envolvendo partes que não se conhecem previamente ou empresas entrantes no mercado. Em sua análise, os autores não encontraram alta correlação entre nível de recursos disponíveis aos tribunais e a eficiência judicial, diferente do que esperavam. Se mais recursos judiciais reduzissem o tempo de disposição (fim dos casos) e, assim, aumentassem a eficiência judicial, haveria uma clara justificativa para recomendar um aumento de fundos para o judicial como um importante elemento da reforma judicial na América Latina. Porém, os resultados apontam para outra direção, os países que não sofrem atrasos e corrupção e contam com um elevado grau de satisfação ou confiança do público no seu sistema judiciário (países como a Dinamarca, o Japão, a Alemanha, os Países Baixos e a Noruega) tendem a empregar menos do orçamento no sistema judiciário do que países latinoamericanos como Argentina, Brasil e México, que têm índices de $20 \%$ de confiança do público. (Buscaglia \& Ulen, 1997).

Há outros fatores que explicam a insatisfação com os tribunais (Buscaglia \& Ulen, 1997). Países onde não há programas de educação especializados ou contínuos em assuntos comerciais, fiscais ou outros assuntos relacionados a negócios, têm juízes e funcionários mal treinados. Outro fator que leva ao alto tempo para a finalização de disputas é a ausência de um estilo ativo de gerenciamento de casos, ou até mesmo uma carga administrativa excessiva que recaí sobre os juízes. Por exemplo, Page (1994), (como citado em Buscaglia \& Ulen (1997) constatou que aproximadamente $65 \%$ do tempo dos juízes brasileiros é gasto em tarefas não judiciais.

Uma implicação importante do trabalho de Buscaglia e Ulen (1997) é que o desenvolvimento da capacidade dos tribunais para satisfazer a demanda é um dos aspectos mais importantes, mas pouco notado, nas estratégias de desenvolvimento econômico da América Latina. Em 1994, os juízes no Brasil citaram a melhoria da tecnologia da informação, a revisão dos procedimentos judiciais e a criação de tribunais de pequeno porte como os elementos mais importantes para uma reforma judicial.

A qualidade judicial reflete a importância das instituições que, por sua vez, afetam as decisões de nível micro, segundo Wang et al. (2014). A baixa qualidade do sistema judiciário 
tem impactos no desenvolvimento econômico de um país, mas também no ambiente microeconômico, o das organizações, onde também apresenta efeitos adversos. No estudo dos autores, eles apontam que busca pela qualidade judiciária com a eficiência do enforcement dos contratos em seu cerne gerará, além de impactos na economia, impactos na vantagem comparativa das empresas exportadoras que necessitam de insumos que apresentam especificidade relacional. Quando a execução do contrato (enforcement) é eficiente, as empresas são mais propensas a se envolverem com novos demandantes ou clientes em geral.

A qualidade judiciária é capaz de afetar as exportações das empresas por meio de sua eficiência na solução de disputas contratuais de negócios. As empresas em regiões com melhor qualidade do sistema judiciário apresentaram, no estudo, vantagem comparativa na exportação dos bens que fornecem insumos intermediários fortemente dependentes de relacionamentos (intensivos em contratos), devido à economia de custos em um sistema eficiente de solução de litígios. Wang et al. (2014) estudaram a questão utilizando dados de exportação de mais de 77.000 empresas em 30 províncias da China e examinaram a importância da qualidade judicial, medida na eficiência do sistema judiciário no enforcement dos contratos e na decisão e no volume de exportação das empresas.

No estudo, Wang et al. (2014) utilizaram-se da premissa que, na China,

Embora as atividades comerciais estejam sujeitas a um sistema regulatório uniforme estabelecido pelo governo central, as autoridades locais têm uma grande liberdade e poder em termos de política econômica e de aplicação da legislação nacional. Como resultado, a capacidade e a visão dos governos locais podem influenciar, em grande medida, o clima empresarial local, e a eficiência (World Bank, 2008, p. 2).

$\mathrm{Na}$ conclusão do estudo, os autores encontraram resultados significativos que indicam que as empresas que dependem intensamente de contratos com intermediários terão maior probabilidade de se tornarem exportadoras quando operam em locais com maior qualidade judicial.

A imperfeição do sistema legal pode ter sérias ramificações no macroambiente: em direito privado, pode levar as partes a buscar remédios privados, como a máfia, para disputas segundo Hay e Shleifer (como citado em Bednar, 2004). No federalismo, Bednar (2004) cita que a falta de um árbitro objetivo pode fazer com que os governos retirem suas disputas do sistema legal e usem mecanismos extremos como guerra civil ou secessão. Além de, no direito contratual, pode reestimular o oportunismo. Obviamente tribunais eficientes, justos e previsíveis também podem trazer união, melhor ambiente de negócios e, em última análise, fomentar o desenvolvimento econômico de um país. 


\subsubsection{Síntese da relevância do Ambiente Institucional e suas Instituições.}

Adam Smith (como citado em Coase, 1998) resume a importância do ambiente institucional

A produtividade do sistema econômico depende da especialização (ele diz a divisão do trabalho), mas a especialização só é possível se houver troca - e quanto menores os custos de troca (custos de transação), ou seja, mais especialização haverá quanto maior a produtividade do sistema. Mas os custos das trocas dependem das instituições de um país: seu sistema legal, seu sistema político, seu sistema social, seu sistema educacional, sua cultura e assim por diante. Com efeito, são as instituições que governam o desempenho de uma economia e é isso que confere à "nova economia institucional" sua importância para os economistas. (Coase, 1998, p.72)

Os mercados, constatou North (1999) exigem não apenas que se elabore amplamente um conjunto de regras do jogo que geralmente se apliquem, mas também que sejam especificadas as estruturas do mercado para que as pessoas possam competir por preço e qualidade para evitar que a competição saia do escopo do preço e qualidade e as pessoas se engajem em comportamentos prejudiciais de oportunismo e se chegue a guerras contratuais. Sendo assim, necessário que todos os mercados sejam estruturados.

Quando falamos sobre direitos de propriedade, e estruturação de mercados em um determinado país ressalta North (1999) deve haver uma estrutura institucional que possa definir um conjunto de regras do jogo, possa especificar essas regras e fornecer mecanismos de fiscalização.

Existe um processo de mudança onipresente contínuo e incremental, segundo North (1994), que é consequência das escolhas dos atores individuais e empresários de organizações. Algumas dessas decisões vão além da rotina e envolvem alterações de regras e de comportamento. Essas mudanças nas instituições acontecem porque os indivíduos percebem que eles poderiam fazer melhor na reestruturação das transações. Natural que nem todas as mudanças sejam imediatamente traduzidas em leis constitucionais, porém quando o assunto é enforcement de contratos, fiscalização de atividades das empresas não pode haver brechas para que o entendimento de quem aplica e fiscaliza as atividades seja discrepante, impactando a sustentabilidade do negócio no longo prazo e o consequente crescimento econômico para os stakeholders.

Enfatizando que a questão primária é estruturar o mercado, North (1999) aponta que uma segunda questão crucial é: o que funciona hoje não vai funcionar amanhã. Existem muitas mudanças ocorrendo; assim, procurar por uma definição e estrutura únicas e estáveis para um mercado não é exatamente a maneira como se deve pensar sobre a criação de 
instituições. A preocupação deve ser em estruturar ambientes institucionais para que eles sejam flexíveis o suficiente para mudar. Então, quando o contexto, a tecnologia ou as dimensões físicas dos problemas ambientais evoluem com o tempo, esses mercados terão flexibilidade e resiliência para continuar funcionando amanhã.

Em vista disso, possuir um sistema judiciário de qualidade (que apresente baixo tempo de resolução de disputas, justiça, imparcialidade, previsibilidade, fácil acesso...) é primordial para inspirar confiança e reduzir a incerteza no ambiente de negócios, para que os gestores, agentes e organizações possam se engajar em transações, negociar e contratar fomentando, dessa forma, o desenvolvimento econômico do país.

\subsection{CONCLUSÃO}

A conclusão deste capítulo teórico e das teorias relacionadas é que a estrutura de governança que se pretende analisar é complexa e inter-relacionada como observado por Ronald Coase (1995) quando recebeu seu premio Nobel; ele salientou que mesmo se começasse com a análise relativamente simples de 'A natureza da empresa', descobrir os fatores que determinam os custos relativos de coordenação pela integração vertical, por contratos ou por transações no mercado não é uma tarefa simples, além de que estes custos não constituem a história em sua completude. A análise não pode se limitar ao que acontece dentro de uma única empresa. Em sua palestra publicada em Lives of the Laureates (Coase, 1995 p. 245), destaca:

Os custos de coordenação dentro de uma empresa e o nível de custos de transação que ela enfrenta são afetados por sua capacidade de comprar insumos de outras empresas, e essa capacidade de fornecer esses insumos depende, em parte, de seus custos de coordenação e do nível de custos de transação que eles enfrentam, que são afetados de forma semelhante pelo que são os custos de coordenação e transação em outras empresas, o que estamos lidando é uma estrutura complexa inter-relacionada. 


\section{EVIDÊNCIAS DAS DIFERENÇAS NOS AMBIENTES INSTITUCIONAIS DO BRASIL E ESTADOS UNIDOS}

$\mathrm{Na}$ busca de evidências que sustentem a premissa que diferentes ambientes institucionais resultem em diferentes estratégias nas empresas e que os sistemas judiciais como garantidores dos acordos e direitos de propriedade transacionados influenciam nas estruturas de governança escolhidas por uma organização, foram escolhidos dois países com diferentes instituições para o estudo ser realizado: o Brasil e os Estados Unidos.

Neste capítulo, serão evidenciadas as diferenças no ambiente institucional dos dois países por meio da pesquisa de diversos autores (Acemoglu et al., 2001; Hall \& Jones, 1999; La Porta, 1996; La Porta et al., 1997; LaPorta et al., 1998; Syam, 2014; Timm, 2009) que investigam o ambiente institucional como origem do desenvolvimento social e econômico.

\subsection{Origem legal e outros indicadores exógenos das diferenças entre as instituições}

A abordagem da origem legal reconhece que o enforcement de contratos e a proteção da propriedade são fatores importantes para o crescimento econômico e o desenvolvimento.

Os sistemas jurídicos nos países ao redor do mundo geralmente se enquadram em duas categorias principais: sistemas de direito comum (common law) e sistemas de direito civil (civil law). Existem cerca de 150 países que têm sistemas de direito civil, enquanto existem cerca de 80 países de direito comum (common law). A maioria dos países adotou seus sistemas legais por meio de ocupação ou colonização de uma das potências europeias. $\mathrm{O}$ Brasil tem seu sistema legal baseado no sistema de direito civil francês, enquanto os Estados Unidos têm o sistema de direito comum inglês (common law).

A Universidade de Direito de Washington publicou em seu site algumas diferenças que caracterizam os dois sistemas jurídicos e suas diferenças. Syam (2014) destaca que a principal diferença entre os dois sistemas é que, nos países de direito comum (common law), a jurisprudência - na forma de pareceres jurídicos publicados pelos juízes - é de importância primordial, ao passo que nos sistemas de direito civil, os estatutos codificados, suas leis e códigos, predominam.

As origens de tais sistemas legais se tornam importante para entender o funcionamento delas. A raiz do sistema de lei comum pode ser rastreada até a monarquia inglesa, que costumava emitir ordens formais chamadas "mandados" (writs em inglês, que pode significar escritas) quando a justiça precisava ser feita. Como os mandados não eram suficientes para cobrir todas as situações, tribunais de equidade foram estabelecidos para ouvir reclamações e elaborar soluções apropriadas baseadas em princípios equitativos extraídos de muitas fontes de 
autoridade (como o direito romano e o direito "natural"). Quando essas decisões foram coletadas e publicadas, tornou-se possível para os tribunais procurar opiniões precedentes e aplicá-las a casos atuais. E assim a lei comum se desenvolveu. A lei civil em outras nações européias, por outro lado, geralmente é rastreada até o código de leis compilado pelo imperador romano Justiniano por volta de 600 EC (era corrente). Códigos legais autorizados com raízes nessas leis (ou outras) foram desenvolvidos ao longo de muitos séculos em vários países, levando a sistemas jurídicos semelhantes, cada um com seus próprios conjuntos de leis. (Syam, 2014, s/p).

A importância de tal origem legal, além de determinar como a justiça é executada também acaba por determinar diferentes resultados econômicos e sociais que os sistemas legais podem imprimir em suas nações ao longo do tempo. A origem legal também desponta como variável explicativa (exógena) porque a relação da qualidade dos sistemas judiciais atuais e o desenvolvimento econômico apresentam problemas de endogeneidade em suas análises; não se sabe se o sistema judiciário tem boa qualidade porque o país é desenvolvido ou se o país é desenvolvido por isso seu sistema judiciário é de qualidade. Sendo a origem legal exógena, significa que não pode ser explicada por um modelo de crescimento econômico.

As pesquisas se iniciaram na área de finanças, primeiramente La Porta (1996) fez conjecturas de que as diferenças na natureza e na eficácia dos sistemas financeiros em todo o mundo poderiam ser atribuídas, em parte, às diferenças nas proteções dos investidores contra a expropriação, como refletidas pelas normas legais e pela qualidade de seu enforcement. Ele encontrou evidências indicando que as normas legais que protegem os investidores e a qualidade do enforcement diferem muito e sistematicamente entre os países.

Ao comparar as regras legais em 49 países, La Porta et al. (1997) mostraram que as regras legais das diferentes tradições diferem em conteúdo, bem como no histórico de sua adoção. Nesse artigo de 1997, os autores tentam avaliar a capacidade das empresas em diferentes ambientes jurídicos de obter financiamento externo por meio de dívida ou patrimônio líquido. Na área de proteção contra a expropriação por parte de insiders, os países de common law protegem melhor os acionistas e credores, os países de direito civil francês tem menor proteção, ficando países de direito civil alemão e direito civil escandinavo em algum lugar no meio.

Alguns dados de La Porta et al. (1997) nos permitem comparar o Brasil e os Estados Unidos e não somente países de origens legais diferentes. Os países de direito comum têm a relação média entre o mercado acionário externo e o Produto Nacional Bruto de $60 \%$, contra $21 \%$ para os países de direito civil francês, nos EUA que de direito comum tem $58 \%$, enquanto o Brasil 18\%. Os países de direito comum têm 35 empresas listadas por milhão de 
pessoas (em média), nos EUA esse número é de 30 por milhão de pessoa; em comparação com dez para os países de direito civil francês e meros 3,5 empresas por milhão de pessoas no Brasil.

Na busca por variáveis exógenas que demonstrem que as instituições são importantes utilizam-se instrumentos para representar as instituições; os instrumentos são variáveis que se correlacionam com as instituições, mas não são correlacionados com o crescimento econômico atual evitando, dessa forma, o problema de endogeneidade nas análises.

Buscando explicar diferenças na acumulação de capital, produtividade e produção por trabalhador Hall e Jones (1999,) no artigo Why Do Some Countries Produce So Much More Output Per Worker Than Others?, investigam que essas variáveis estão fundamentalmente relacionadas às diferenças na infraestrutura social entre os países. Por infraestrutura social, eles entendem as instituições e políticas governamentais que determinam o ambiente econômico no qual os indivíduos acumulam habilidades e as empresas acumulam capital e produzem produto.

Países com funcionários corruptos no governo, impedimentos severos ao comércio, aplicação deficiente de contratos e interferência do governo na produção não conseguirão atingir níveis de produção por trabalhador em qualquer lugar perto dos níveis da Europa Ocidental, da América do Norte e do leste da Ásia (Hall \& Jones, 1999).

Todavia, infraestrutura social é endógena ao desempenho econômico como observado por Hall e Jones (1999); portanto, o desempenho econômico regressivo na infraestrutura social resultaria em estimativas tendenciosas. Assim, foi necessário encontrar instrumentos para infraestrutura social, sendo escolhidos aqueles correlatos da extensão da influência da Europa Ocidental. Foram utilizadas características da geografia, como a distância do equador a até em que ponto as línguas primárias da Europa Ocidental são faladas hoje em dia como primeiras línguas. Essas características foram utilizadas como medidas da extensão em que uma economia é influenciada pela Europa Ocidental, a primeira região do mundo a implementar amplamente uma infraestrutura social favorável à produção, seguindo as ideias de Adam Smith e a importância dos direitos de propriedade e o sistema de verificações e balanços no governo.

Que a extensão com que as línguas da Europa Ocidental são faladas como língua materna está correlacionada com a extensão da influência da Europa Ocidental parece perfeitamente natural. No entanto, pode-se perguntar sobre a correlação entre a distância do equador e a influência da Europa Ocidental. Sugerimos que isso seja plausível por dois motivos. Primeiro, os europeus ocidentais eram mais propensos a migrar para as regiões do mundo que eram escassamente povoadas no início do século XV. Regiões como Estados Unidos, Canadá, Austrália, Nova Zelândia e Argentina parecem satisfazer esse critério. Em segundo lugar, 
parece que os europeus ocidentais estavam mais propensos a se estabelecer em áreas que eram amplamente semelhantes no clima à Europa Ocidental, o que novamente aponta para regiões distantes do equador. (Hall \& Jones, 1999, p. 101)

Os achados da pesquisa de Hall e Jones (1999) sustentaram a maior parte da alta correlação simples entre a distância do equador e o desempenho econômico, o que ocorre porque as circunstâncias históricas levam essa variável a representar bem a infraestrutura social. A grande variação na produção por trabalhador entre os países é apenas parcialmente explicada por diferenças no capital físico e no nível educacional. As diferenças na infraestrutura social entre os países causam grandes diferenças na acumulação de capital, no nível educacional e na produtividade, e, por conseguinte, grandes diferenças na renda entre os países.

Assim sendo, a diferença na infraestrutura social entre Brasil e Estados Unidos, países utilizados na pesquisa, pode ser explicada também pelo nível de influência dos países da Europa Ocidental, sendo a distância do equador uma proxy válida. Sugerindo que a colonização e estabelecimento nos Estados Unidos, distante 4.422,5 quilômetros do equador e com um clima mais parecido com os países colonizadores, levou a melhor construção desta infraestrutura do que no Brasil, distante somente 1.112,3 quilômetros e com clima diferente que dificultou o estabelecimento dos colonos.

Outro trabalho semelhante que busca na colonização variáveis exógenas para explicar as grandes diferenças na renda per capita entre os países é o artigo The Colonial Origins of Comparative Development: An Empirical Investigation de Acemoglu et al. (2001). Os autores exploraram as diferenças nas taxas de mortalidade na Europa para estimar o efeito das instituições no desempenho econômico, uma vez que os europeus adotaram políticas de colonização distintas em diferentes colônias, com diferentes instituições associadas. Em um extremo, as colônias europeias eram Estados extrativos, em que o objetivo era transferir a maior quantidade de recursos para os colonizadores, sem se preocuparem em criar proteções de direito de propriedade, ou proteções contra a expropriação do governo. Em outro extremo, os europeus migraram e se estabeleceram criando as Neo-Europas, em que os colonizadores tentaram replicar as instituições europeias, garantir os direitos de propriedade e proteção contra o poder do Estado. Exemplos desse último tipo de colonização incluem a Austrália, Nova Zelândia, Canadá e Estados Unidos.

Essas diferenças, segundo premissas de Acemoglu et al. (2001), se relacionam com a viabilidade dos assentamentos e das altas taxas de mortalidade e doenças que os europeus encontravam nas colônias, nesses locais onde eles não conseguiam se estabelecer, era mais 
propenso a serem criadas instituições extrativistas, as quais persistiram até o presente. Os autores, inclusive, citam o exemplo do Brasil como de manutenção de instituições estatais extrativistas após a independência, fornecidas pela permanência das políticas mais proeminentes, como a escravidão que persistiu até 1886.

O artigo de Acemoglu et al. (2001) que explora as diferenças nas taxas de mortalidade europeias como um instrumento para as instituições atuais estima grandes efeitos das instituições sobre a renda per capita. Uma importante observação é que o argumento não é que as diferenças nas taxas de mortalidade sejam as principais causas das instituições atuais. Pelo contrário, as taxas de mortalidade dos colonos são uma fonte de variação exógena e, por isso, se constituem em um bom instrumento.

\subsection{Indicadores de governança do sistema judiciário}

Diversos institutos de pesquisa levantam dados e publicam índices sobre a qualidade de governança dos países ao redor do mundo. O Banco Mundial é um dos mais conhecidos, principalmente por reunir diversas fontes e indicadores e formar um indicador unificado. Suas fontes incluem especialistas e levantamentos ao redor do mundo e esse é o motivo de se utilizar, neste trabalho, os dados levantados pelo referido banco. O projeto Indicadores Globais de Governança (WGI) reporta indicadores de governança agregados e individuais para mais de 200 países e territórios durante o período 1996-2017, para seis dimensões de governança: i) Voz e Responsabilidade; ii) Estabilidade Política e Ausência de Violência; iii) Eficácia do governo; iv) Qualidade Regulatória; v) Estado de Direito; e vi) Controle da Corrupção (Kaufmann \& Kraay, 2019).

A governança no projeto consiste nas tradições e instituições pelas quais a autoridade em um país é exercida. Isso inclui o processo pelo qual os governos são selecionados, monitorados e substituídos; a capacidade do governo para formular e implementar efetivamente políticas sólidas; e o respeito dos cidadãos e do Estado pelas instituições que governam as interações econômicas e sociais entre eles.

A Tabela 3 compara os indicadores do Brasil e dos Estados Unidos para os anos de 2000, 2008 e 2017, nas dimensões dos indicadores de governança do projeto. O número de fontes é o número de fontes individuais em que o índice agregado é baseado; a pontuação de governança é medida em uma escala que varia de $-2,5$ a 2,5 , onde valores mais altos 
correspondem a melhor desempenho da governança; e o ranking de percentis indica qual a posição do país, baseada em todos os países do mundo.

Tabela 3: Indicadores de governança do Brasil e Estados Unidos

\begin{tabular}{|c|c|c|c|c|c|c|}
\hline Indicador & País & Ano & $\begin{array}{l}\text { Número de } \\
\text { fontes }\end{array}$ & $\begin{array}{c}\text { Pontuação de } \\
\text { Governança } \\
(-2,5 \text { a } 2,5)\end{array}$ & $\begin{array}{l}\text { Ranking } \\
(0-100)\end{array}$ & Erro padrão \\
\hline \multirow[t]{6}{*}{ Voz e Responsabilidade } & \multirow[t]{3}{*}{ Brasil } & 2000 & 9 & 0,30 & 58,21 & 0,19 \\
\hline & & 2008 & 17 & 0,57 & 63,94 & 0,13 \\
\hline & & 2017 & 15 & 0,45 & 61,58 & 0,13 \\
\hline & \multirow[t]{3}{*}{ Estados Unidos } & 2000 & 8 & 1,31 & 89,05 & 0,20 \\
\hline & & 2008 & 14 & 1,14 & 86,54 & 0,14 \\
\hline & & 2017 & 12 & 1,05 & 82,27 & 0,14 \\
\hline \multirow{6}{*}{$\begin{array}{l}\text { Estabilidade Política e } \\
\text { Ausência de Terrorismo }\end{array}$} & \multirow[t]{3}{*}{ Brasil } & 2000 & 5 & 0,19 & 53,97 & 0,31 \\
\hline & & 2008 & 8 & $-0,31$ & 33,65 & 0,24 \\
\hline & & 2017 & 9 & $-0,41$ & 31,43 & 0,21 \\
\hline & \multirow[t]{3}{*}{ Estados Unidos } & 2000 & 5 & 1,08 & 82,54 & 0,31 \\
\hline & & 2008 & 8 & 0,59 & 66,83 & 0,24 \\
\hline & & 2017 & 9 & 0,30 & 59,05 & 0,21 \\
\hline \multirow[t]{6}{*}{ Eficácia do Governo } & \multirow[t]{3}{*}{ Brasil } & 2000 & 6 & 0,09 & 61,03 & 0,19 \\
\hline & & 2008 & 11 & $-0,09$ & 52,43 & 0,20 \\
\hline & & 2017 & 10 & $-0,29$ & 41,83 & 0,20 \\
\hline & \multirow[t]{3}{*}{ Estados Unidos } & 2000 & 5 & 1,80 & 92,31 & 0,21 \\
\hline & & 2008 & 7 & 1,61 & 92,23 & 0,23 \\
\hline & & 2017 & 7 & 1,55 & 92,79 & 0,22 \\
\hline \multirow{6}{*}{ Qualidade Regulatória } & \multirow[t]{3}{*}{ Brasil } & 2000 & 7 & 0,36 & 65,13 & 0,22 \\
\hline & & 2008 & 10 & 0,05 & 54,37 & 0,18 \\
\hline & & 2017 & 10 & $-0,11$ & 51,44 & 0,19 \\
\hline & \multirow[t]{3}{*}{ Estados Unidos } & 2000 & 6 & 1,76 & 95,38 & 0,24 \\
\hline & & 2008 & 7 & 1,53 & 93,2 & 0,23 \\
\hline & & 2017 & 8 & 1,63 & 92,79 & 0,22 \\
\hline \multirow{6}{*}{$\begin{array}{l}\text { Estado de Direito } \\
\text { (Rule of Law) }\end{array}$} & \multirow[t]{3}{*}{ Brasil } & 2000 & 11 & $-0,21$ & 44,06 & 0,16 \\
\hline & & 2008 & 17 & $-0,32$ & 46,15 & 0,14 \\
\hline & & 2017 & 14 & $-0,28$ & 43,75 & 0,16 \\
\hline & \multirow[t]{3}{*}{ Estados Unidos } & 2000 & 8 & 1,59 & 93,07 & 0,16 \\
\hline & & 2008 & 12 & 1,64 & 92,31 & 0,16 \\
\hline & & 2017 & 11 & 1,64 & 91,83 & 0,16 \\
\hline \multirow[t]{6}{*}{ Controle da Corrupção } & \multirow[t]{3}{*}{ Brasil } & 2000 & 7 & 0,04 & 58,88 & 0,19 \\
\hline & & 2008 & 14 & 0,01 & 59,88 & 0,15 \\
\hline & & 2017 & 14 & $-0,53$ & 36,06 & 0,12 \\
\hline & \multirow[t]{3}{*}{ Estados Unidos } & 2000 & 6 & 1,66 & 922,39 & 0,2 \\
\hline & & 2008 & 12 & 1,45 & 91,75 & 0,15 \\
\hline & & 2017 & 11 & 1,38 & 88,94 & 0,13 \\
\hline
\end{tabular}

Fonte: (Banco Mundial, 2019; Kaufmann \& Kraay, 2019)

Na tabela, pode-se identificar que a pontuação para as dimensões que estão sendo discutidas na pesquisa, a Qualidade Regulatória, indicador que captura percepções da capacidade do governo de formular e implementar políticas e regulamentos sólidos que permitam e promovam o desenvolvimento do setor privado, bem como a dimensão Estado de Direito, que indica as percepções sobre até que ponto os agentes confiam e respeitam as 
regras da sociedade e, em particular, a qualidade da execução de contratos, os direitos de propriedade, a polícia e os tribunais, além da probabilidade de crime e violência (Kaufmann, Kraay, \& Mastruzzi, 2010).

O Gráfico 2 - Índice de qualidade regulatória do Brasil e Estados Unidos e o Gráfico 3 - Índice de Estado de Direito no Brasil e Estados Unidos expõem a diferença acentuada dos indicadores no Brasil e nos Estados Unidos ao longo dos anos, mostrando que, além da diferença do ranking, as diferenças entre eles são significativas e excedem o erro padrão estabelecido.

Gráfico 2: Índice de Qualidade Regulatória do Brasil e Estados Unidos

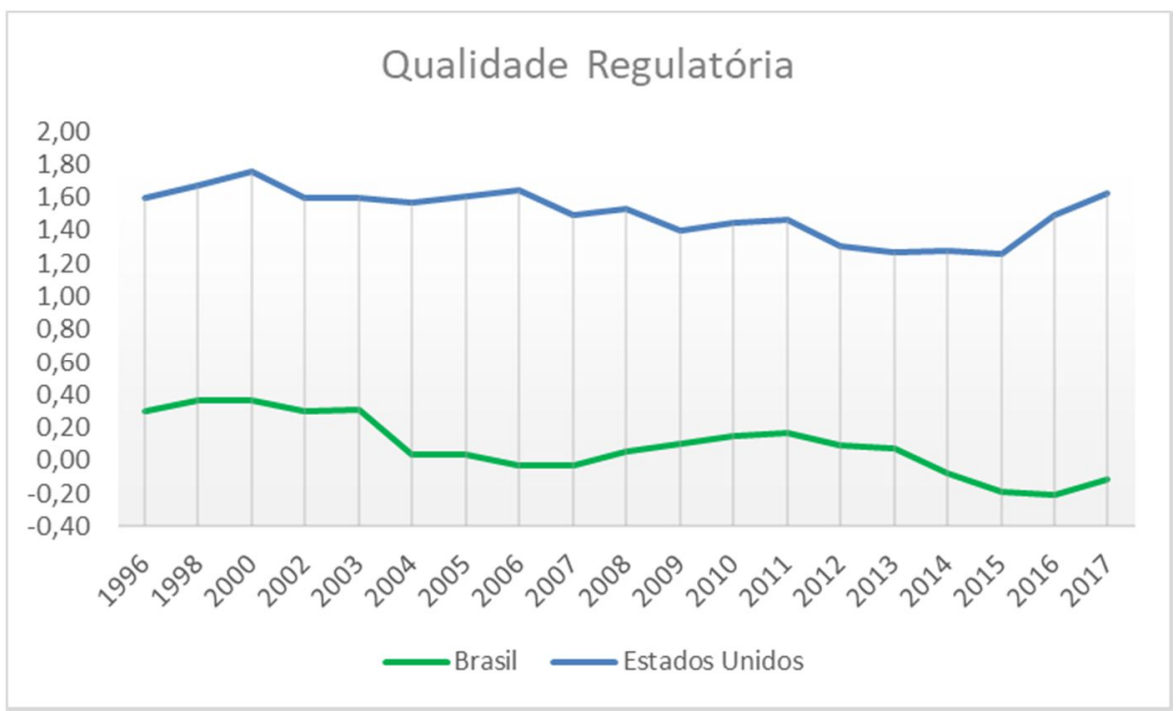

Fonte: elaborado pela autora, com base em Banco Mundial (2019); Kaufmann \& Kraay (2019)

Gráfico 3: Índice de Estado de Direito no Brasil e Estados Unidos

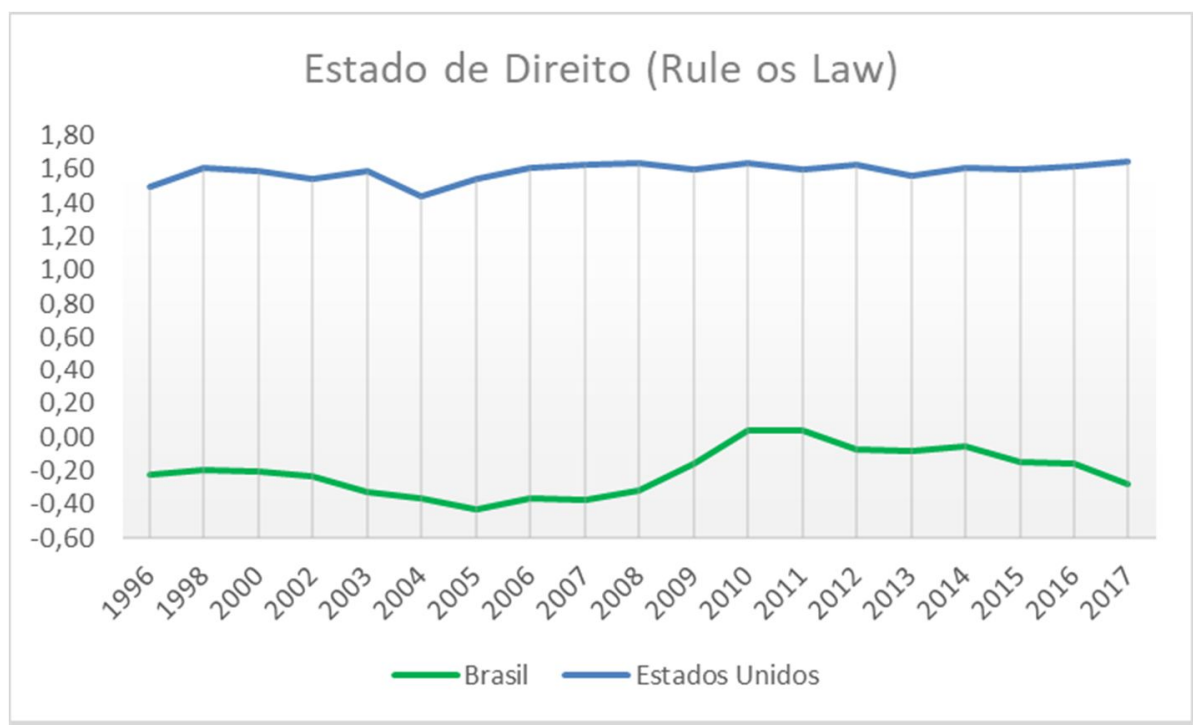

Fonte: elaborado pela autora, com base em Banco Mundial (2019); Kaufmann \& Kraay (2019) 


\subsection{O sistema judiciário e seus paradigmas contratuais}

O Código Civil brasileiro mais recente conhecido como NCC (Novo Código Civil) foi publicado em 2002 e introduziu mudanças no Direito Privado no Brasil. Uma das inovações trazidas foi o Artigo 421 do Código Civil (Brasil, 2002, s/p.), que dispõe que "A liberdade de contratar será exercida em razão e nos limites da função social do contrato".

Uma cláusula genérica como esta acabou por gerar diversas interpretações e disputas de paradigmas sobre o significado e interpretação da função social do contrato (Timm, 2009).

Existem, de acordo com Timm (2009), dois paradigmas conflitantes na doutrina jurídica brasileira referentes à função social do contrato que surgem da interpretação do artigo 421. O primeiro paradigma, o que ele chama de modelo solidarista (ou paternalista, como preferem os norte-americanos) do direito contratual, está embasado em uma visão coletivista sociológica da sociedade e, por conseguinte, dos contratos. O segundo, o modelo de direito e economia do direito contratual - que se vale da noção individualista do que vem a ser um contrato e de sua função na sociedade.

Segundo Sanches e Bataglia (2015, p. 10), essas particularidades dos dois paradigmas têm um contexto histórico e merece contextualização. Os autores explicam que

Embora seja costume atribuir à lei romana a origem e base de vários conceitos relacionados a contratos, o contrato como é considerado hoje no sistema legal brasileiro resulta de uma evolução significativa que começou com a ascensão do capitalismo e teve seus projetos essenciais delineados dos ideais defendidos pela Revolução Francesa. O direito contratual brasileiro importou noções fundamentais de livre-arbítrio e autonomia, e liberdade de contrato, especialmente do Código Francês, também chamado de Código Napoleônico.

Assim, de acordo com Fiuza (2007), como citado em Sanches e Bataglia (2015), inicialmente a noção clássica de direito contratual brasileiro baseava-se em dogmas de vontade autônoma dos indivíduos como elemento essencial na organização do Estado e nas relações contratuais; no princípio da liberdade econômica; e na concepção formal de liberdade e igualdade que seria fornecida e garantida por lei.

No entanto, com o advento da Revolução Industrial e o avanço do capitalismo, Gomes (2008) afirma que houve a transformação do Estado Liberal em Estado de Bem-Estar, que resultou na modificação do conceito de contratos. A suposição de que a mera igualdade proporcionada pela lei asseguraria o equilíbrio entre os contratantes, ignorando suas condições sociais, era entendida como irrealista. Algumas relações contratuais mostraram a existência de desigualdade entre as partes e consequente insatisfação de grandes setores da 
população devido ao desequilíbrio, levando à demanda por intervenção do Estado na vida econômica (Sanches \& Bataglia, 2015).

Essa situação colide com os princípios de autonomia de vontade e liberdade de contrato contemplados pela visão clássica brasileira de direito contratual, chocando-se com o dogma do liberalismo. A partir dessa evolução, vem o formato contemporâneo do direito contratual, como é encontrado atualmente no sistema legal brasileiro. Basicamente, o direito contemporâneo convive com a existência de uma dialética permanente entre concepções liberais e sociais, segundo Venosa (2013), como citado em Sanches e Bataglia (2015). Em outras palavras, a autonomia da vontade e a liberdade contratual dos agentes permanecem válidas, embora limitadas pelos princípios que salvaguardam os interesses sociais impostos pela lei e pelo Estado.

Logo, esse paradigma solidarista identifica a função social do contrato com o propósito de equilibrar os poderes econômicos entre as partes sob a ótica da justiça distributiva que é inerente ao Estado Social. Em seu ensaio, Timm (2009) demonstra que o quase consenso encaminhado pela doutrina jurídica nacional é falho ao sustentar a função social do contrato com base na ideia de justiça distributiva e fazer 'justiça social' pela via contratual.

Nesse sentido, a função social do direito contratual garantiria a predominância dos interesses coletivos (ou sociais) sobre os interesses individuais, no âmbito do contrato, pensamento resultante das desigualdades sociais que seriam refletidas nos acordos privados. Então, a distribuição de riqueza, por meio dos contratos, seria injusta se não fosse regulada, e o Estado deveria proteger a parte mais fraca na relação contratual privada (Timm, 2009).

O modelo implica a proteção da parte mais fraca na relação contratual - que sucumbe ao poder de barganha da parte economicamente mais forte. Tratando-se, então de um modelo que supõe fictícia a liberdade contratual, uma vez que não existe liberdade de contratar se há, de fato, aguda disparidade de poder entre as partes, sendo mais correto, então, falar em submissão da parte mais fraca. Daí a necessidade de intervenção do Estado para reequilibrar tal relação (seja pelo legislador, seja pelo juiz). O princípio da função social do contrato é visto, nesse quase consenso solidarista, como uma limitação ao princípio da liberdade contratual (autonomia privada).

Em um estudo sobre o assunto, Castelar (2009) evidencia que uma das principais preocupações dos magistrados do $1^{\circ}$ grau é com a justiça social. Segundo a sua pesquisa, mais de 70\% dos juízes entrevistados preferem fazer 'justiça social' a aplicar a 'letra fria' da lei e do contrato. Essa informação é demonstrada na decisão do Tribunal de Justiça do Estado do 
Rio Grande do Sul, que concluiu: "A função social do contrato tem por objetivo evitar a imposição de cláusulas onerosas e danosas aos contratantes economicamente mais fracos" (Tribunal de Justiça do RS, 2005, p. 1), ou quando no ano de 2005 em diversas apelações proibiu uma instituição financeira de aplicar juros compostos e impôs a aplicação de juros simples em um empréstimo realizado.

Ante sua onerosidade excessiva, resta afastada a aplicação da Tabela Price, comprovadamente dotada de ilegal e inconveniente incidência de juros compostos. Deve-se proceder à aplicação de juros simples à espécie, preservando-se, destarte, o necessário equilíbrio do contrato, bem assim dando-se ensancha à consagração de sua propalada função social (Tribunal de Justiça do Estado do Rio Grande do Sul, 2005, p. 1).

Nesse sentido, com base na função social dos contratos, alguns juízes têm revisado os acordos entre as partes para equilibrar o poder.

Apesar da tentativa de proteção da parte mais fraca da transação, Timm (2009) conclui por meio de uma análise econômica que o modelo solidarista não é capacitado para alcançar o seu propósito de bem-estar na sociedade, uma vez que poderá, aleatoriamente, beneficiar alguns indivíduos, mas, proporcionalmente, prejudicar muitos outros mais, uma vez que usualmente o benefício desta justiça de redistribuição via contrato é destinado à parte protegida no litígio sem nenhum resultado coletivamente benéfico aos demais. Ademais, a excessiva intervenção judicial pode originar externalidades negativas, uma vez que o risco ou a perda efetiva do litígio pela parte considerada 'mais forte' tende a ser repassado à coletividade, que acaba pagando pelo elo mais fraco judicialmente protegido.

O estudo de Rezende e Zylbersztajn (2012) ilustra essa situação ao explorar a instabilidade criada por decisões judiciais contraditórias relativas a violações contratuais nas transações do agronegócio. Os autores verificaram que as câmaras da mesma corte, nesse caso, a Justiça do Estado de Goiás, haviam proferido decisões diferentes em casos semelhantes, revelando um ambiente institucional jurídico muito inseguro. As disputas estavam relacionadas aos contratos de soja quebrados pelos produtores, devido ao aumento dos preços da soja. Enquanto alguns tribunais favoreciam os compradores, decidindo pela continuidade forçada do contrato entre as partes, outros decidiram a favor dos agricultores, de acordo com o argumento da função social e do equilíbrio econômico. Nesse estudo, os autores observam como o sistema agroindustrial foi afetado por efeitos de segunda ordem, como resultado desse contexto incerto; houve demandas de garantias mais rigorosas por parte dos credores, maior dificuldade de negociação com os compradores, menor quantidade de contratos a termo, entre outros fatores, que também começaram a prejudicar os produtores que não quebraram os contratos. 
Os efeitos distributivos da reconfiguração dos direitos privados são difíceis de prever segundo Cooter e Ulen (2016), e os tribunais não podem ter certeza que beneficiarão o coletivo ou que redistribuirão os custos, podendo em último caso aumentar o custo total do mercado. Desse modo, a parte protegida está externalizando os custos aos demais para o seu próprio benefício, resultando em situação socialmente ineficiente.

Adicionalmente, na prática os custos de transação da redistribuição por meio de direitos legais privados são tipicamente altos. Para ilustrar, Cooter e Ulen (2016) usam o exemplo do advogado do autor que trabalha com uma taxa de contingência e cobra rotineiramente um terço do julgamento. Se o advogado do réu cobrar uma quantia similar em honorários por hora, os advogados dos dois lados absorverão dois terços das apostas em disputa na lógica solidarista.

A excessiva intervenção judicial nos contratos pode trazer instabilidade jurídica e insegurança ao ambiente econômico, acarretando mais custos de transação às partes. Tal instabilidade é também retratada por Almeida e Zylbersztajn (2012), em um estudo sobre o mercado de crédito rural no Brasil. Sua pesquisa revelou que os agentes se empenham em não recorrer aos tribunais para resolver disputas decorrentes de contratos de crédito; a principal razão é a incerteza gerada pelo poder judiciário ao credor sobre o resultado das ações judiciais, uma vez que o devedor pode obter uma decisão favorável, dependendo da interpretação do juiz. O estudo aponta três efeitos imediatos resultantes da insegurança jurídica para as operações de crédito: a) os agentes restringem a oferta ou transferem seu risco para a taxa de juros a ser cobrada; b) a exigência de quantidade e qualidade de garantias é levantada para inibir o oportunismo do tomador; e c) há uma forte prática de outros mecanismos, como análise de risco e perfil, reputação e coleta de informações sobre o mutuário, a fim de minimizar o risco de inadimplência.

De acordo com Sztajn e Zylbersztajn (2005), esse cenário de justiça ineficiente e a fragilidade das alternativas de solução de disputas afetam a economia dos contratos porque o desenho do contrato leva em conta a capacidade de enforcement dos tribunais e as formas mais eficazes de resolução de disputas. Nesse diapasão, o contexto brasileiro parece propiciar um ambiente institucional legal que gera altos custos de transação por sua falha em resguardar os interesses contratuais dos agentes.

O paradigma conflitante ao solidarismo e paternalismo relatado por Timm (2009) é o ponto de vista da análise econômica do direito. Em uma perspectiva de direito e economia, o contrato, de fato (ou como um fato) é uma transação entre duas partes na qual cada parte se comporta de acordo com os seus interesses para criar valor. Dessa forma, como evidenciado 
pela teoria dos jogos, uma parte somente irá se engajar e cooperar com a outra na medida em que puder desfrutar de algum benefício proporcionado pelo jogo.

Por conseguinte, Timm (2009) analisa que não se pode pensar em interesses sociais em uma relação contratual e descuidar do ambiente em que esta relação é celebrada - o mercado. O mercado é um espaço público de interação social e coletiva que tendem a situações de equilíbrio entre as partes. Nas palavras de (Coase, 1987, p. 7), o mercado "é a instituição que existe para facilitar a troca de bens e serviços, isto é, existe para que se reduzam os custos de se efetivarem operações de trocas". Há a necessidade de se criar incentivos à cooperação entre as partes, que tende a gerar valor a ser negociado e dividido entre elas. $\mathrm{O}$ direito contratual e o enforcement dos contratos são capazes de gerar incentivos à cooperação e assegurar às partes o cumprimento do contrato.

Dessa forma, ao se seguir o paradigma de direito e economia, os bens e serviços deverão circular de acordo com a vontade das partes, expressa nos contratos, sendo direcionados à parte que mais os valorize. Uma vez que os indivíduos possuem interesses distintos e sejam suficientemente racionais para estabelecer uma escala de preferências, estarão, assim, aptos a maximizar a sua utilidade no processo de transação, o que resultará em geração de riqueza na sociedade. A lei se envolve somente quando alguém procura ter uma promessa imposta pelo estado.

O direito contratual, sob a ótica da eficiência econômica, busca o respeito ao direito de propriedade e deseja a realização de transações que não ocorreriam sem as suas regras, uma vez que protege as expectativas das partes e cria obrigações legais que podem ser objetos de negociação. Inexistindo o direito dos contratos, as partes teriam dificuldades em estabelecer relações impessoais.

Os elementos básicos necessários para que o contrato seja legalmente executável na maior parte dos estados dos Estados Unidos são: consentimento mútuo, expresso por uma oferta válida e aceitação; consideração adequada; capacidade; e legalidade (Kim, 2007).

De acordo com Cooter e Ulen (2016), em países de direito comum (lei julgada pelo juiz), a teoria econômica sobre direito contratual baseia-se em promessas legalmente executáveis, que só ocorre se a promessa for dada como parte de uma barganha; caso contrário, uma promessa não é executável pela lei.

A barganha ocorre em um diálogo sobre valor para se chegar a um preço, e os teóricos distinguem três elementos necessários: oferta, aceitação e consideração. A "oferta" e "aceitação" têm o mesmo significado do que é comumente conhecido: uma parte deve fazer uma oferta, e a outra deve aceitá-lo. O direito comum (common law) usa o termo técnico "consideração" para descrever o que o prometido dá a outra parte para induzir a promessa. As formas de uma barganha incluem, portanto, dinheiro-por-promessa, mercadoria-por-promessa, 
serviço-por-promessa e promessa-por-promessa. Segundo a teoria da barganha, o contrato permanece incompleto até que o prometido dê algo ao promitente para induzir a promessa. Quando concluído, o contrato se torna executável. Em outras palavras, a consideração torna a promessa executável. De acordo com a teoria da barganha, o tribunal deveria fazer cumprir as promessas induzidas por consideração, independentemente de a consideração ser equivalente ao valor à promessa. É suficiente para o enforcement do acordo que quem aceitou achou a consideração adequada para induzir a promessa. Esta teoria sustenta que os tribunais devem determinar se uma barganha ocorreu, e não investigar se a barganha foi justa. Consequentemente, a doutrina da consideração exige que os tribunais apliquem algumas promessas injustas. (Cooter \& Ulen, 2016, p. 278).

Supervisionar todas as barganhas em busca de justiça sobrecarregaria os tribunais e inibiria o comércio, segundo (Cooter \& Ulen, 2016). Consequentemente, a maioria das pessoas quer que os tribunais garantam os acordos e não supervisionem todos eles. No entanto, algumas barganhas são tão unilaterais que exige poucas informações para condenálas como injustas. Tribunais modernos dos EUA, às vezes, se recusam a impor barganhas extremamente unilaterais. Na maioria dos países de língua inglesa, a doutrina tradicional da common law exige somente a 'consideração' para que uma promessa seja executável.

Conforme Cooter e Ulen (2016), de acordo com a "teoria da vontade" (will theory), um contrato vinculativo requer uma intenção das partes em vincular-se. Quando cada parte pretende cumprir a promessa, suas vontades se encontram, ocorrendo o "meeting of minds" (encontro das mentes), o contrato é criado.

O encontro das mentes, ou acordo mútuo, requer a aprovação real por ambas as partes para a formação de um contrato, incluindo acordo sobre os mesmos termos, condições e assunto. Somente quando todas as partes envolvidas estão conscientes da formação de uma obrigação legal a reunião de mentes ocorre. O consentimento mútuo deve ser provado objetivamente, e é geralmente estabelecido mostrando uma oferta e aceitação. (Litvin, 2009).

Diante dessa comparação entre os paradigmas do direito contratual no Brasil e nos Estados Unidos, observa-se que, quando as regras não são claras e seguras, pode haver aumento da incerteza nas transações, aumentando os custos de transação. Ao elevar esses custos, o direito contratual no Brasil pode eliminar algumas práticas negociais do mercado.

\subsection{Terceirização no Brasil: Súmula 331 do TST e a Lei 13.429 de 2017}

A subcontratação de serviços não tinha legislação própria até 2017 , e poderia se encaixar no direito contratual, no direito trabalhista. Anteriormente à Lei 13.429 (Brasil, 2017) e com o aumento da prática da terceirização, principalmente transferindo à terceiros a 
mão de obra especializada o Direito do Trabalho tentou preencher a lacuna com a Sumula 331 do TST, para direcionar a contratação de empregados terceirizados no Brasil.

A corte trabalhista no Brasil inicialmente não era a favor da terceirização de nenhuma forma, por acreditar que precarizava a mão de obra e a transformava em mercadoria. No entanto posteriormente editou a Súmula n. 256 e passou a admiti-la de forma limitada. Após várias críticas, a súmula foi revisada e originou a Súmula n. 331 do TST (Tribunal Superior do Trabalho, 2011), a qual passou por uma última modificação em maio de 2011, pela Resolução Administrativa n. 174/2011 (BRASIL, 2011, p. 1), sua última versão.

Dispõe da seguinte forma:

SUM-331 CONTRATO DE PRESTAÇÃO DE SERVIÇOS. LEGALIDADE (nova redação do item IV e inseridos os itens V e VI à redação) - Res. 174/2011, DEJT divulgado em 27, 30 e 31.05.2011.

I - A contratação de trabalhadores por empresa interposta é ilegal, formando-se o vínculo diretamente com o tomador dos serviços, salvo no caso de trabalho temporário (Lei n ${ }^{0} 6.019$, de 03.01.1974).

II - A contratação irregular de trabalhador, mediante empresa interposta, não gera vínculo de emprego com os órgãos da Administração Pública direta, indireta ou fundacional (art. 37, II, da $\mathrm{CF} / 1988$ ).

III - Não forma vínculo de emprego com o tomador a contratação de serviços de vigilância (Lei $\mathrm{n}^{\circ}$ 7.102, de 20.06.1983) e de conservação e limpeza, bem como a de serviços especializados ligados à atividade-meio do tomador, desde que inexistente a pessoalidade e a subordinação direta.

IV - O inadimplemento das obrigações trabalhistas, por parte do empregador, implica a responsabilidade subsidiária do tomador dos serviços quanto àquelas obrigações, desde que haja participado da relação processual e conste também do título executivo judicial.

$\mathrm{V}$ - Os entes integrantes da Administração Pública direta e indireta respondem subsidiariamente, nas mesmas condições do item IV, caso evidenciada a sua conduta culposa no cumprimento das obrigações da Lei ${ }^{\circ}{ }^{\circ} 8.666$, de 21.06.1993, especialmente na fiscalização do cumprimento das obrigações contratuais e legais da prestadora de serviço como empregadora. A aludida responsabilidade não decorre de mero inadimplemento das obrigações trabalhistas assumidas pela empresa regularmente contratada.

VI - A responsabilidade subsidiária do tomador de serviços abrange todas as verbas decorrentes da condenação referentes ao período da prestação laboral. (BRASIL, 2011, p. 1)

Tal súmula fez com que a terceirização enfrentasse os tribunais do Direito do Trabalho e delimitava quando a terceirização era lícita ou ilícita, sendo sua licitude apresentada em casos excepcionais: trabalho temporário, serviços de vigilância, conservação e limpeza e serviços especializados ligados a atividade-meio do tomador do serviço. A Súmula 331 do TST vedava a contratação de terceirizados para as atividades-fim da empresa, sendo somente permitida a subcontratação das atividades-meio.

$\mathrm{O}$ art. 581, $\S 2^{\circ}$ da CLT conceitua o que se entende por atividade-fim:

Art. 581. Para os fins do item III do artigo anterior, as empresas atribuirão parte do respectivo capital às suas sucursais, filiais ou agências, desde que localizadas fora da base territorial da entidade sindical representativa da atividade econômica do estabelecimento principal, na proporção das correspondentes operações econômicas, fazendo a devida comunicação às 
Delegacias Regionais do Trabalho, conforme localidade da sede da empresa, sucursais, filiais ou agências.

$\S 1^{\circ}$ Quando a empresa realizar diversas atividades econômicas, sem que nenhuma delas seja preponderante, cada uma dessas atividades será incorporada à respectiva categoria econômica, sendo a contribuição sindical devida à entidade sindical representativa da mesma categoria, procedendo-se, em relação às correspondentes sucursais, agências ou filiais, na forma do presente artigo.

$\S 2^{\circ}$ Entende-se por atividade preponderante a que caracterizar a unidade de produto, operação ou objetivo final, para cuja obtenção todas as demais atividades convirjam, exclusivamente em regime de conexão funcional.

Não foi apresentado, no entanto, um consenso sobre o que seriam as atividades-fim da empresa, dificultando o entendimento em que a regra era aplicada. $\mathrm{Na}$ tentativa de solucionar tal dificuldade, normalmente, fazia-se a verificação da atividade-fim por meio da análise do contato social.

Primeiramente, em 1988, foi apresentado o Projeto de Lei 4.302/1998, sobre as relações de trabalho na empresa de trabalho temporário e na empresa de prestação de serviços a terceiros e em 2004 na Comissão de Constituição e Justiça da Câmara um projeto de lei, o PL 4330/2004, que dispunha sobre o mesmo assunto: o contrato de prestação de serviço a terceiros e as relações de trabalho dele decorrentes. Por um longo período, esses assuntos ficaram inertes na Câmara de Deputados até em 2015 voltarem à discussão no ambiente político.

Existem movimentos sindicalistas contrários, em que alegam que essas propostas são nocivas à classe trabalhadora. A Central Única dos Trabalhadores (CUT) alega desde que os projetos de lei são discutidos que os trabalhadores terceirizados possuem salários menores que o dos empregados diretos; que trabalhavam 3 (três) horas a mais por semana, que há um enfraquecimento da Previdência, perda de direitos como aviso-prévio e recebimento de multa nos casos de demissão sem justa-causa, além de aumento do número de acidentes de trabalho, discriminação, agressões e lesões físicas e psíquicas e são mais acometidos por doenças ocupacionais.

A diretriz acolhida pelo PL $\mathrm{n}^{\circ} 4.330-\mathrm{A} / 2004$, ao permitir a generalização da terceirização para toda a economia e a sociedade, certamente provocará gravíssima lesão social de direitos sociais, trabalhistas e previdenciários no País, com a potencialidade de provocar a migração massiva de milhões de trabalhadores hoje enquadrados como efetivos das empresas e instituições tomadoras de serviços em direção a um novo enquadramento, como trabalhadores terceirizados, deflagrando impressionante redução de valores, direitos e garantias trabalhistas e sociais.(CUT, 2017, s/p.).

No entanto, Lazzarini (2014) apresenta o questionamento se a precarização da mão de obra era causada pela subcontratação ou pela falta de fiscalização de uma determinada 
atividade, e sugere que a solução para aderir às práticas trabalhistas adequadas não deveria passar pela obrigação da empresa de integrar verticalmente a atividade.

A justificativa do Sr. Sandro Mabel quando apresentou o projeto de lei PL 4330/2004 foi que

No Brasil, a legislação foi verdadeiramente atropelada pela realidade. Ao tentar, de maneira míope, proteger os trabalhadores simplesmente ignorando a terceirização, conseguiu apenas deixar mais vulneráveis os brasileiros que trabalham sob essa modalidade de contratação. As relações de trabalho na prestação de serviços a terceiros reclamam urgente intervenção legislativa, no sentido de definir as responsabilidades do tomador e do prestador de serviços e, assim, garantir os direitos dos trabalhadores. (PL 4330/2004, 2004, p.6)

Em 31 de março de 2017, o presidente da república em exercício sancionou a Lei 13.429, de março de 2017, que o Congresso Nacional votou e decretou. A nova lei rege as relações de trabalho na empresa de trabalho temporário, na empresa de prestação de serviços e nas respectivas tomadoras de serviço e contratante. O principal ponto é que, para a prestação de serviços, torna-se lícito o contrato de terceirização relacionado à parcela de qualquer atividade da contratante $\left(\right.$ Art. $\left.9^{\circ}, \S 3^{\circ}\right)$.

Segundo o Art. $9^{\circ} \S 1$ "é responsabilidade da empresa contratante garantir as condições de segurança, higiene e salubridade dos trabalhadores, quando o trabalho for realizado em suas dependências ou em local por ela designado"; e o e §2 ressalta que "contratante estenderá ao trabalhador da empresa de trabalho temporário o mesmo atendimento médico, ambulatorial e de refeição destinado aos seus empregados, existente nas dependências da contratante, ou local por ela designado (Brasil, 2017, s/p.).

A lei inclui o contratante como fiscal na relação contratual, dando a ele poder e dever de fiscalizar o cumprimento das obrigações trabalhistas decorrentes do contrato e o torna solidário em relação às obrigações trabalhistas previstas relacionadas aos trabalhadores terceirizado (Art. 10. §7).

Após a lei ser publicada e entrar em vigor, também o Supremo Tribunal Federal em 30 de agosto de 2018 decidiu que:

É lícita a terceirização em todas as etapas do processo produtivo, seja meio ou fim. Ao julgar a Arguição de Descumprimento de Preceito Fundamental (ADPF) 324 e o Recurso Extraordinário (RE) 958252, com repercussão geral reconhecida, sete ministros votaram a favor da terceirização de atividade-fim e quatro contras.

A tese de repercussão geral aprovada no RE foi a seguinte: "É lícita a terceirização ou qualquer outra forma de divisão do trabalho entre pessoas jurídicas distintas, independentemente do objeto social das empresas envolvidas, mantida a responsabilidade subsidiária da empresa contratante". (Supremo Tribunal Federal, 2018, s/p).

Nos Estados Unidos não há legislação exclusiva para regular atividades terceirizadas, sendo enquadradas no direito contratual. 


\subsection{Conclusão}

O ambiente institucional dos dois países comparados nesta pesquisa, Brasil e Estados Unidos, apresenta distinções quando consideramos seus sistemas judiciais, os paradigmas do direito contratual, a predictabilidade das decisões judiciais baseadas na legislação, a confiança das partes nas cortes e tribunais. Tais diferenças encontram explicações em origens históricas, baseadas na colonização, na origem do sistema judiciário, na base do direito contratual e até mesmo nas distâncias deles até o Equador.

Fato é que essas diferenças influenciam o ambiente de negócios e as transações, impactando nas escolhas estratégicas das empresas. Algumas estruturas de governança que poderiam fornecer vantagem competitiva para as empresas acabam sendo evitadas, porque encontram neste ambiente incerteza e altos custos de transação para ocorrer.

A terceirização é considerada pela NEI uma opção estratégica de organizar no mercado ou por meio de contratos uma atividade que poderia ocorrer dentro do escopo da firma.

Após muito tempo sendo proibida de ocorrer na maioria das atividades, pelo entendimento do Tribunal Superior do Trabalho (TST), por meio da Súmula 331 do TST a terceirização foi regulamentada pela Lei 13.429, de 2017. Existia a percepção dos órgãos ligados ao trabalho que ao terceirizar uma atividade, a empresa precarizava a mão de obra contratada. A nova lei, no entanto, coloca o contratante como fiscal e o responsabiliza solidariamente à empresa contratada, caso alguma das regras do jogo não sejam respeitadas.

Contudo, o paradigma solidarista (ou paternalista) em que o direito contratual se submete à função social do contrato gera instabilidade no sistema judiciário e imprevisibilidade às decisões dos tribunais, aumentando a incerteza no ambiente institucional e compelindo os agentes a e evitarem situações que consideram de risco. Consequentemente, práticas de terceirização de atividades eventualmente são evitadas nas organizações.

Desse modo, com o intuito de proteger as partes mais fracas do contrato, ou da relação trabalhista, o executivo e o judiciário causam problemas de segunda ordem na sociedade, que acaba por absorver as externalidades dessas medidas: menos investimentos das empresas no País, consequentemente menor número de postos de trabalho, menos formalização de empregos temporários, custos repassados para a sociedade, aumento dos custos de capital das instituições financeiras são alguns exemplos dos impactos da 'justiça social'. 


\section{ANÁLISE DOS ESTUDOS DE CASO}

\subsection{Terceirização de serviços na agricultura dos Estados Unidos}

\subsubsection{Introdução}

Os Estados Unidos são um dos maiores produtores, consumidores, exportadores e importadores de commodities agrícolas do mundo: o valor da produção agrícola atingiu U\$S388 bilhões em segundo o Censo agrícola 2017 (United States Department of Agriculture, 2017). A agricultura dos Estados Unidos é dominada pelos grãos, oleaginosas, gado, leite, aves e frutas e vegetais. Segundo o Censo de 2017, em média, as culturas representaram 49,8\% de toda a produção agropecuária e a pecuária 50,2\%. A Tabela 4 mostra todos os valores das culturas e a quantidade de fazendas no território do país.

Tabela 4: Valor de Mercado dos Produtos Agropecuários dos Estados Unidos

\begin{tabular}{|c|c|c|c|}
\hline \multicolumn{3}{|c|}{ VALOR DE MERCADO DOS PRODUTOS AGRÍCOLAS } & Porcentagem \\
\hline \multirow[t]{2}{*}{ VENDAS TOTAIS } & fazendas & $2.042 .220,00$ & 100 \\
\hline & U\$S(1000) & $388.522 .695,00$ & 100 \\
\hline \multirow[t]{2}{*}{ Culturas } & fazendas & 1.017.021,00 & 49,8 \\
\hline & U\$S(1000) & $193.546 .699,00$ & 49,8 \\
\hline \multirow[t]{2}{*}{ Grãos, sementes oleaginosas } & fazendas & $451.716,00$ & 22,1 \\
\hline & U\$S(1000) & $106.868 .126,00$ & 27,5 \\
\hline \multirow[t]{2}{*}{ Milho } & fazendas & $319.966,00$ & 15,7 \\
\hline & U\$S(1000) & $51.219 .763,00$ & 13,2 \\
\hline \multirow[t]{2}{*}{ Trigo } & fazendas & $104.618,00$ & 5,1 \\
\hline & U\$S(1000) & $7.882 .905,00$ & 2,0 \\
\hline \multirow[t]{2}{*}{ Soja } & fazendas & $302.742,00$ & 14,8 \\
\hline & U\$S(1000) & $40.304 .487,00$ & 10,4 \\
\hline \multirow[t]{2}{*}{ Sorgo } & fazendas & $16.962,00$ & 0,8 \\
\hline & U\$S(1000) & $1.576 .008,00$ & 0,4 \\
\hline \multirow[t]{2}{*}{ cevada } & fazendas & $11.083,00$ & 0,5 \\
\hline & U\$SS(1000) & $685.026,00$ & 0,2 \\
\hline \multirow[t]{2}{*}{ Arroz } & fazendas & $4.629,00$ & 0,2 \\
\hline & U\$SS(1000) & $2.123 .480,00$ & 0,5 \\
\hline \multirow[t]{2}{*}{ Outros grãos } & fazendas & $44.479,00$ & 2,2 \\
\hline & U\$S(1000) & $3.076 .456,00$ & 0,8 \\
\hline \multirow[t]{2}{*}{ Tabaco } & fazendas & $6.234,00$ & 0,3 \\
\hline & U\$S(1000) & $1.474 .376,00$ & 0,4 \\
\hline \multirow[t]{2}{*}{ Algodão } & fazendas & $16.104,00$ & 0,8 \\
\hline & U\$SS(1000) & $6.685 .609,00$ & 1,7 \\
\hline \multirow[t]{2}{*}{ Vegetais } & fazendas & $75.320,00$ & 3,7 \\
\hline & U\$S(1000) & $19.583 .739,00$ & 5,0 \\
\hline \multirow[t]{2}{*}{ Frutas } & fazendas & $109.994,00$ & 5,4 \\
\hline & U\$S(1000) & $28.581 .398,00$ & 7,4 \\
\hline \multirow[t]{2}{*}{ Floricultura, estufa. } & fazendas & $46.970,00$ & 2,3 \\
\hline & U\$S(1000) & $16.174 .082,00$ & 4,2 \\
\hline \multirow[t]{2}{*}{ Arvores de Natal } & fazendas & $10.559,00$ & 0,5 \\
\hline & U\$SS(1000) & $386.149,00$ & 0,1 \\
\hline \multirow[t]{2}{*}{ Outras culturas e feno } & fazendas & $513.608,00$ & 25,1 \\
\hline & U\$S(1000) & $13.793 .221,00$ & 3,6 \\
\hline \multirow[t]{2}{*}{ Pecuária, aves e seus produtos } & fazendas & $986.790,00$ & 48,3 \\
\hline & U\$S(1000) & $194.975 .996,00$ & 50,2 \\
\hline
\end{tabular}

Fonte: (United States Department of Agriculture, 2017, p.7) 
Para a economia dos Estados Unidos, o comércio de produtos agrícolas é uma fonte importante de geração de valor, empregos e renda. Em 2018, as exportações de produtos agrícolas atingiram U\$S 140 bilhões e um superávit de U\$S10,9 bilhões na balança comercial, menor valor desde 2006, as importações cresceram nos Estados Unidos, impulsionadas em parte pelo forte crescimento econômico doméstico. Em análise, o Economic Research Service (ERS) do departamento de agricultura dos Estados Unidos (USDA) mostrou que cada dólar recebido da exportação de comoddities estimulava outros U\$S1,64 de atividades de apoio (USDA, 2018).

Para alcançar resultados expressivos é preciso que as propriedades sejam eficientes e busquem constantemente aumento de produtividade em produtos, bem como em valores financeiros. O ambiente institucional desempenha um importante papel no desenvolvimento das organizações, como constatou Douglas North (1991, 1992, 1994, 2005) ao declarar que as instituições são importantes.

O estudo de caso pretende investigar a relação que o sistema judiciário e o Estado de Direito, componente importante do ambiente institucional tem na tomada de decisões de agricultores ao contratar ou não determinada atividade. Uma vez que esse ambiente pode fomentar a geração de negócios entre as partes quando diminui a incerteza ou apresentar um resultado oposto e incentivar a integração vertical quando gera incerteza no ambiente de negócios. As diferenças nos ambientes institucionais e no sistema judiciário dos Estados Unidos e do Brasil foram destacadas no capítulo anterior, no estudo de caso serão analisadas as informações coletadas por meio das entrevistas dos estudos de caso que ocorreram no Estado do Missouri, Estados Unidos. As categorias de análise do estudo de caso, conforme foram apresentadas na metodologia, serão as do Quadro 7.

Quadro 7: Categorias de Análise do Estudo de Caso dos Estados Unidos.

\begin{tabular}{|c|c|}
\hline Categoria de Análise & Elementos Observados \\
\hline Perfil e Network da empresa & $\begin{array}{ll}\text { - } & \text { Tamanho das empresas } \\
\text { - } & \text { Contratos de terceirização de atividades } \\
\text { - } & \text { Atividades integradas verticalmente } \\
\text { - } & \text { Recursos da empresa }\end{array}$ \\
\hline $\begin{array}{lll}\begin{array}{l}\text { Arquitetura } \\
\text { atividades }\end{array} & \text { Organizacional } & \text { das } \\
\end{array}$ & $\begin{array}{ll}\text { - } & \text { Estrutura de Governança (Direito de decisão). } \\
\text { - } & \text { Valor criado pela transação } \\
\text { - } & \text { Incerteza e Risco }\end{array}$ \\
\hline Interferências do Sistema judiciário & $\begin{array}{ll} & \text { Influência da responsabilidade judicial } \\
\text { - } & \text { Levantamento de intervenções judiciais } \\
\text { - } & \text { Termos de Ajustamento de Conduta (TAC) } \\
\text { - } & \text { Impacto na estratégia da empresa } \\
\end{array}$ \\
\hline Sistema judiciário & $\begin{array}{ll}\text { - } & \text { Percepção da qualidade do sistema judiciário } \\
\text { - } & \text { Confiança na imparcialidade do sistema judiciário } \\
\text { - } & \text { Percepção da responsabilidade judicial } \\
\text { - } & \text { Confiança nos tribunais e cortes } \\
\end{array}$ \\
\hline
\end{tabular}

Fonte: elaborado pela autora (2018) 


\subsubsection{O contexto: a agricultura no Missouri, Estados Unidos}

O estado do Missouri tem uma economia de US\$ 303 bilhões e é o terceiro estado economicamente mais diversificado do país. A manufatura representa aproximadamente $13 \%$ do produto bruto do Estado, seguida pelo governo, imóveis e assistência médica. A agricultura, com suas lavouras tem um valor de vendas de U\$S 5,4 bilhões e a pecuária e seus subprodutos U\$S 5 bilhões, segundo o Censo Agropecuário dos Estados Unidos (United States Department of Agriculture, 2017).

Trinta por cento da população do Missouri vive fora das áreas metropolitanas nas partes mais rurais do estado, a agropecuária (produção de culturas, pecuária e madeira) é uma atividade importante para as economias estadual e local. Existem 95.320 fazendas no Missouri - o segundo maior número de qualquer estado nos Estados Unidos. O Agronegócio, que inclui a agricultura, o processamento, a distribuição e os serviços de produtos agrícolas relacionados, contribuiu diretamente com US \$ 15,2 bilhões para a economia do estado - 5,4\% do produto interno bruto (PIB) do Missouri (Missouri Economic Research and Information Center, 2016).

Três por cento de todos os trabalhadores do Missouri estão envolvidos nas propriedades agrícolas, a Figura 11, na página seguinte, mostra a concentração de trabalhadores rurais no Estado. O agronegócio - que inclui indústrias agrícolas e de manufatura, distribuição e serviços relacionados à agricultura - representa 5\% do total de empregos no Missouri: 182.383 trabalhadores. A agricultura é responsável por 53\% de todos os trabalhadores do agronegócio no estado: 96.840. O emprego na manufatura relacionada à agricultura é responsável por quase $30 \%$ da força de trabalho do agronegócio: 53.770. Outros 17\% são provenientes de serviços e distribuição relacionados à agricultura: 31.773. 


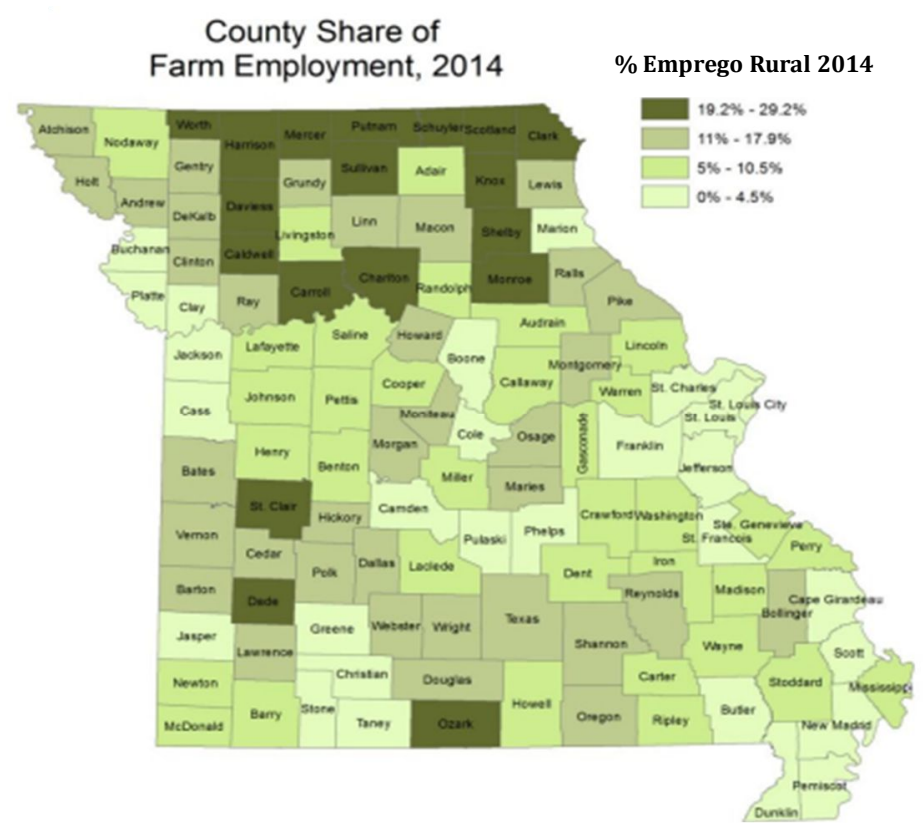

Fonte: Missouri Economic Research and Information Center, 2016, p.1.

Em 2014, o Missouri tinha uma estimativa de 100.400 empresas do agronegócio (97.700 fazendas e 2.700 empresas relacionadas à agricultura) empregavam diretamente 182.383 trabalhadores, pagavam US \$6,4 bilhões em salários e contribuíam com US \$15,2 milhões bilhões para o PIB estadual. O efeito cascata aumentava em US \$ 9,6 bilhões a atividade econômica adicional. O impacto total do agronegócio, incluindo os efeitos intermediários e induzidos, sobre a economia do estado foi de US \$24,8 bilhões, o que representa $8,9 \%$ do produto interno bruto do Missouri. Setores agrícolas e indústrias indiretas empregavam 305.256 trabalhadores, pagando cerca de US \$12,1 bilhões em salários.

Tabela 5: Impacto do Agronegócio na Economia do Missouri

\begin{tabular}{|c|c|c|c|}
\cline { 2 - 4 } \multicolumn{1}{c|}{} & Direto & Indireto & Total \\
\cline { 2 - 4 } Empregos & 182.383 & 122.873 & 305.256 \\
\hline Renda & U\$ 6.4 bilhões & U\$ 5.7 bilhões & \$12.1 bilhões \\
\hline PIB & U\$ 15.2 bilhões & U\$ 9.6 bilhões & U\$ 24.8 bilhões \\
\hline
\end{tabular}

Fonte: traduzido pela autora (2018), com base em Missouri Economic Research and Information Center, 2016, p. 2 
A classificação das fazendas nos EUA é pela renda agrícola anual bruta (GCFI $=$ gross cash farm income). E segue a seguinte tipologia segundo (Hoppe \& MacDonald, 2013) do Serviço de Pesquisa Econômica do USDA:

Fazendas de aposentadoria: Pequenas fazendas cujos principais operadores relatam que estão aposentadas, embora continuem a cultivar em pequena escala.

Ocupação não agrícola: Pequenas fazendas cujos principais operadores relatam uma ocupação primária que não a agricultura. A categoria também inclui fazendas (cerca de $18 \%$ das fazendas de ocupação fora da fazenda) cujos operadores não se consideram na força de trabalho.

Pequenas propriedades familiares: Pequenas fazendas cujos principais operadores relatam a agricultura como sua ocupação principal, essa categoria é subdividida em baixo volume de renda bruta, de vendas moderadas.

Fazendas familiares de médio possuem renda bruta entre US\$ 350.000 e US \$ 999.999.

Fazendas familiares em larga escala que possuem GCFI de US\$ 1.000 .000 ou mais e se subdividem em grandes propriedades e fazendas muito grande que possuem renda bruta de mais de US\$ 5.000.000 ou mais.

Fazendas não familiares. Fazendas onde um operador e pessoas relacionadas ao operador não possuem a maioria dos negócios. (United States Department of Agriculture, 2018, s/p).

As propriedades são divididas conforme a Tabela 6, segundo o Censo Agrícola de 2012.

Tabela 6: Perfil fazendas no estado do Missouri

\begin{tabular}{|c|c|c|c|c|c|c|c|c|c|}
\hline & & \multirow{3}{*}{ Todas as fazendas } & \multicolumn{3}{|c|}{ Pequenas propriedades familiares } & \multirow{3}{*}{$\begin{array}{c}\text { Propriedades } \\
\text { familiares médias }\end{array}$} & \multirow{2}{*}{\multicolumn{2}{|c|}{$\begin{array}{l}\text { Propriedades familiares de grande escala:> de } \\
\qquad \$ 1.000 .000\end{array}$}} & \multirow{3}{*}{$\begin{array}{c}\text { Propriedades não } \\
\text { familiares }\end{array}$} \\
\hline & & & & Fazendas de a & gricultura & & & & \\
\hline \multicolumn{2}{|l|}{ Fazendas } & & Não Agrícola & Renda $<\$ 150.000$ & $<\$ 349.999$ & & Grandes: $<\$ 4.999 .999$ & $\begin{array}{l}\text { Muito grande:> } \\
\$ 5.000 .000\end{array}$ & \\
\hline \multirow[t]{2}{*}{ Fazendas } & $n$ & 99.171 & 72.370 & 15.781 & 3.371 & 3.627 & 1.136 & 66 & 2.820 \\
\hline & $\%$ & 100 & 73 & 16 & 3 & 4 & 1 & 0 & 3 \\
\hline TOTAL fazendas (hectares) & & 11.438 .910 & 4.793 .871 & 1.548 .243 & 1.026 .344 & 2.054 .314 & 1.317 .875 & 145.381 & 552.883 \\
\hline Tamanho médio (hectares) & & 115 & 66 & 98 & 304 & 567 & 1.160 & 2.203 & 196 \\
\hline $\begin{array}{l}\text { \% fazendas (tamanho } \\
\text { médio) }\end{array}$ & & 100 & 42 & 14 & 9 & 18 & 12 & 1 & 5 \\
\hline
\end{tabular}

Fonte: traduzido pela autora desta pesquisa de United States Department of Agriculture (2012, s/p.)

Nessas fazendas, os produtos que mais ocupam área plantada são soja, milho, forrageiras, trigo e sorgo, conforme dados coletados em 2018 pelo USDA, que estão discriminados na Tabela 7, apresentada na página seguinte: 
Tabela 7: Visão global da agricultura do Missouri em 2018

\begin{tabular}{|c|c|c|c|}
\hline Commodity & Colheita (hectares) & Produtividade & Produção (toneladas) \\
\hline \multicolumn{4}{|l|}{ SOJA } \\
\hline SOJA & $2.347 .178,80$ & $45 \mathrm{BU} / \mathrm{ACRE}$ & $7.103 .973,87$ \\
\hline \multicolumn{4}{|l|}{ MILHO } \\
\hline \multicolumn{4}{|l|}{ MILHO } \\
\hline MILHO GRÃO & $1.347 .604,38$ & $140 \mathrm{BU} / \mathrm{ACRE}$ & $11.842 .105,26$ \\
\hline MILHO SILAGEM & $40.468,60$ & 13 TONS / ACRE & $1.300 .000,00$ \\
\hline \multicolumn{4}{|l|}{ FENO E SILAGEM } \\
\hline FENO E SILAGEM & $1.282 .854,62$ & 1.81 TONS / ACRE DRY BASIS & $5.737 .000,00$ \\
\hline FENO E SILAGEM (Alfafa) & $117.358,94$ & 2.68 TONS / ACRE DRY BASIS & $778.000,00$ \\
\hline FENO E SILAGEM (excluído Alfafa) & $1.165 .495,68$ & 1.72 TONS / ACRE DRY BASIS & $4.959 .000,00$ \\
\hline \multicolumn{4}{|l|}{ TRIGO } \\
\hline TRIGO INVERNO & $210.436,72$ & $59 \mathrm{BU} / \mathrm{ACRE}$ & $835.057,16$ \\
\hline TRIGO & $210.436,72$ & $59 \mathrm{BU} / \mathrm{ACRE}$ & $835.057,16$ \\
\hline \multicolumn{4}{|l|}{ SORGO } \\
\hline \multicolumn{4}{|l|}{ SORGO } \\
\hline SORGO SILAGEM & $2.832,80$ & 12 TONS / ACRE & $84.000,00$ \\
\hline SORGO GRÃO & $8.498,41$ & $100 \mathrm{BU} / \mathrm{ACRE}$ & $53.342,82$ \\
\hline
\end{tabular}

Fonte: traduzido pela autora desta pesquisa de National Agricultural Statistics Service (2018, s/p.)

A principal indústria do agronegócio do estado, em termos de PIB total ou agregação de valor, é a produção de carne e aves. Vários produtores proeminentes de carnes e aves têm operações no estado, incluindo a Tyson's, a Smithfield, a Simmons e a Butterball. Outras indústrias de agronegócio de alto valor agregado são a agricultura de oleaginosas, cervejarias e fabricação de alimentos para animais de estimação. As empresas globais Monsanto, Anheuser Busch e Nestlé Purina estão sediadas em St. Louis, MO.

O valor bruto de produtos agrícolas vendidos do Missouri, segundo o Censo Agrícola 2017, está dividido conforme a Tabela 8 (vide página seguinte). A pecuária, a avicultura e os grãos são as commodities que mais geram vendas no Estado, alimentando a indústria da região. Os valores da produção agrícola são do Censo 2017, porém o ranking foi publicado no ano de 2012. 
Tabela 8:Perfil do Estado do Missouri: Ranking dos Produtos Agrícolas

\begin{tabular}{|c|c|c|c|}
\hline Item & Valor $(\$ 1000)$ & Ranking EUA ${ }^{1}$ & Universo \\
\hline \multicolumn{4}{|c|}{ VALOR DE MERCADO DE PRODUTOS AGRÍCOLAS VENDIDOS (\$1000) } \\
\hline Valor total de produtos agrícolas & 10.525 .938 & 16 & 50 \\
\hline Valor das culturas & 5.476 .314 & 17 & 50 \\
\hline Valor do gado, aves e seus produtos & 5.049 .624 & 14 & 50 \\
\hline \multicolumn{4}{|c|}{ VALOR DAS VENDAS POR GRUPOS DE COMMODITIES (\$1000) } \\
\hline Grãos e oleaginosas & 4.824 .806 & 11 & 50 \\
\hline Tabaco & 405 & 15 & 19 \\
\hline Algodão e sementes de algodão & 226.588 & 9 & 17 \\
\hline Vegetais e tubérculos & 65.609 & 31 & 50 \\
\hline Frutas & 28.112 & 25 & 50 \\
\hline Floricultura, estufas. & 119.701 & 30 & 50 \\
\hline Culturas lenhosas e árvores de natal & 927 & 28 & 49 \\
\hline Outras culturas e feno & 210.167 & 27 & 50 \\
\hline Aves e ovos & 1.272 .599 & 9 & 50 \\
\hline Gado e bezerros & 1.869 .893 & 9 & 50 \\
\hline Leite de origem animal & 221.909 & 25 & 50 \\
\hline Porcos & 1.272 .599 & 7 & 50 \\
\hline Ovelhas, cabras e derivados & 20.440 & 15 & 50 \\
\hline Cavalos & 17.183 & 20 & 50 \\
\hline Aquicultura & 12.761 & 25 & 50 \\
\hline Outros animais & 8.705 & 32 & 50 \\
\hline \multicolumn{4}{|l|}{ CULTURAS MAIS CULTIVADAS (acres) } \\
\hline Soja (grãos & 5.868 .690 & 4 & 45 \\
\hline Forrageiras & 3.366 .938 & 2 & 50 \\
\hline Millho (grãos) & 3.425 .341 & 11 & 49 \\
\hline Trigo (grãos e outros) & 552.829 & 14 & 49 \\
\hline
\end{tabular}

Fonte: traduzido pela autora desta pesquisa de United States Department of Agriculture (2017, s/p.)

\subsubsection{Perfil das propriedades rurais no Estudo de Caso do Missouri}

Os perfis das propriedades do estudo de caso são de produção agrícola de grãos, soja, milho, sorgo e trigo, uma vez que representam a maior área produtiva do estado, bem como um fluxo de atividades semelhantes. Apesar da produção pecuária e de suínos seja responsável por grande parte do PIB da agropecuária do estado, não foi parte do escopo do estudo de caso. Mesmo em entrevistas nas quais a atividade de produção animal estava presente, o foco foi na parte de cultivo de grãos. Todas as propriedades entrevistadas produziam majoritariamente soja e milho, algumas diversificavam e, ocasionalmente, produziam sorgo e trigo. 
As entrevistas foram realizadas em oito propriedades rurais no Estado do Missouri, sendo os proprietários os respondentes na maioria das vezes. Seguindo a tipologia das propriedades rurais, sugerida pelo USDA, as propriedades que integraram os estudos foram pequenas propriedades, médias, grandes ou muito grandes. Apesar de não ter os dados financeiros de faturamento, foi comparado o tamanho médio das propriedades com os dados da Tabela 6, para enquadrar as propriedades em pequenas, médias ou grandes. O perfil resumido das propriedades participantes do estudo de caso é apresentado no Quadro 8.

Quadro 8: Perfil das propriedades rurais dos Estados Unidos

\begin{tabular}{|c|c|c|c|c|}
\hline Produtor & $\begin{array}{c}\text { Área total } \\
\text { propriedade } \\
\text { (hectares) }\end{array}$ & $\begin{array}{c}\text { Área produção } \\
\text { grãos (ha) }\end{array}$ & Culturas & $\begin{array}{c}\text { Número colaboradores } \\
\text { (família incluída) }\end{array}$ \\
\hline US1 & 2000 & 2000 & $\begin{array}{c}\text { Soja } \\
\text { Milho }\end{array}$ & 3 \\
\hline US2 & 700 & 700 & $\begin{array}{c}\text { Soja } \\
\text { Milho }\end{array}$ & $28^{*}$ \\
\hline US3 & 2300 & 1000 & $\begin{array}{c}\text { Grãos } \\
\text { Suinocultura }\end{array}$ & 4 \\
\hline US4 & 1000 & 2300 & $\begin{array}{c}\text { Soja } \\
\text { Milho }\end{array}$ & 4 \\
\hline US5 & 300 & 1335 & $\begin{array}{c}\text { Soja } \\
\text { Milho }\end{array}$ & 3 \\
\hline US6 & 1335 & 100 & $\begin{array}{c}\text { Soja } \\
\text { Milho }\end{array}$ & 2 \\
\hline US7 & 100 & 200 & $\begin{array}{c}\text { Soja } \\
\text { Milho }\end{array}$ & 1 \\
\hline US8 & 200 & & & 4 \\
\hline
\end{tabular}

*funcionários envolvidos na suinocultura

Fonte: elaborado pela autora (2019)

Considerando-se as classificações da referida tabela, tem-se que: foram duas entrevistas em pequenas propriedades, com área média de 150 hectares; uma entrevista em uma propriedade média de 700 hectares e quatro entrevistas em propriedades de grande escala com média de 1.650 hectares. O US 5 possui uma pequena propriedade de 350 hectares, porém como presta serviço de custom farming, ele administra e realiza as operações em 2.350hectares. A custom farming, ou agricultura personalizada em tradução livre, é uma alternativa ao arrendamento de terras agrícolas, ou parceria. O operador concorda em realizar todas as operações na propriedade em troca de uma taxa fixa ou porcentagem. O proprietário paga por todas as sementes, produtos químicos e outros insumos, e mantém todos os pagamentos de colheitas e mercadorias. 
A atividade principal de seis das oito propriedades do estudo de caso era destinada a produção agrícola de grãos. No entanto o US1 e o US3 têm atividades principais diferentes, dentro do agronegócio ou mesmo fora dele, contudo o foco do estudo foi nas atividades agrícolas de produção de grãos.

Todas as propriedades rurais tinham em média três pessoas na operação e administração, variando de um a quatro funcionários, proporcionalmente à sua área. $\mathrm{Na}$ maioria das vezes, as pessoas que trabalham nas propriedades são familiares, sendo que os proprietários somente recorrem a outras pessoas, fora da família, se necessário. Em todas as propriedades entrevistadas foi declarado que a quantidade de recursos humanos era o suficiente na operação, e que se sazonalmente eles precisassem de alguém, poderiam contratar trabalhadores em tempo parcial ou contratar algum serviço específico.

A estrutura de equipamentos das fazendas varia de acordo com suas atividades e porte. Em 6 propriedades a estrutura era bem completa em relação às atividades que desenvolvem, possuindo a maioria dos equipamentos para as atividades do dia-a-dia: plantadeiras, pulverizadores, colheitadeiras. Somente em duas propriedades os proprietários não possuem nenhum equipamento; entre elas uma se enquadra no perfil de pequena propriedade com 100 hectares e outra delas tem o perfil de grande propriedade, com 2.300 hectares, esta última não tem a produção dos grãos como atividade principal.

$\mathrm{Na}$ maioria das vezes, a história da atividade agrícola remete a gerações muito anteriores às que estão atualmente na gestão da propriedade. Seguem alguns dos relatos:

"Os pais dos meus bisavôs vieram da Alemanha e trabalharam em uma fazenda e compraram uma propriedade, eles quase perderam tudo durante a grande depressão, mas como a propriedade era próxima à cidade, continuaram a vender ovos e outras coisas para a cidade. Após as gerações passarem, o meu avô cuidava da propriedade, mas morreu eletrocutado em 1970 em um acidente na operação; o filho mais velho de seis irmãos, então, assumiu. Atualmente é o filho mais velho, meu tio, que administra a fazenda, com meu pai e eu. Este é a quinta geração que está na fazenda, eu me demiti do emprego que tinha recentemente para me juntar à operação.” (Produtor US2)

“A fazenda é centenária e está na família desde 1907, iniciou com meu bisavô e avô. Meu avô tinha três filhos e eles continuaram a cultivar na fazenda. Os três se formaram na Universidade do Missouri e eu, quarta geração na operação, me formei em Economia Agrícola também na Universidade do Missouri, e voltei há quatro anos para ajudar na propriedade." (Produtor US4) 
“Comecei fazendo parceria agrícola com um terceiro, em uma fazenda que o meu pai também já tinha cultivado quando eu era criança. Eu expandi minha operação para outras parcerias agrícolas usando o equipamento que alugava do meu pai. Quando aumentei a a operação, adquiri equipamentos próprios, atualmente, além de cultivar minhas próprias fazendas, também presto serviços para terceiros na aplicação de fertilizantes, de defensivos e colheita. Além disso tenho pessoal especializado que realiza a manutenção em minhas máquinas. " (Produtor US6)

“A família está no ramo agrícola há muito tempo. Temos descendência alemã e estamos na quarta geração na agricultura, desde que a família chegou aos EUA" (Produtores US7). Os dois sócios, no entanto, são jovens e estão no sexto ano de operações como sócios, desde que saíram da faculdade de Economia Agrícola e resolveram empreender, independentes das famílias.

O produtor da US5 relatou que na década de 1960 o pai e o tio assumiram as operações quando o avô faleceu; ele está desde a década de 1970 na operação. Começou, no entanto, a prestar serviços de colheita customizada para terceiros e então, em 1987, começaram a cultivar, ele e o irmão, em terras próprias. Atualmente têm uma pequena propriedade, mas a maior operação deles é na prestação de serviços diversificados (custom farming) para outros agricultores.

No entanto, alguns poucos entram na agricultura para diversificar os negócios: “A atividade principal da família é na área de construção e resolvemos diversificar e plantar 2000 hectares de grãos há sete anos." (Produtor US1)

Outros diversificam e expandem as operações, mas no próprio setor agropecuário: “A família está desde 1921 na fazenda com produtos agrícolas; em 1954, meus pais começaram a se especializar em produção de porcos para expandir o negócio. Após terminar a faculdade, me juntei a operação, que era de cultivo de grãos. Hoje terceirizamos a produção de grãos das fazendas e utilizamos para alimentar os porcos."( Produtor US3).

\subsubsection{Arquitetura organizacional}

A arquitetura organizacional dos acordos adaptado por (Sykuta, 2012) considera três variáveis se equilibram como uma banqueta de três pernas da arquitetura organizacional de (Brickley et al., 1995). Os acordos alocam em sua estrutura i) valor, ii) incerteza (e os riscos relacionados a ela) e iii) os direitos de decisões entre as partes, de uma maneira que equilibre 
os interesses das partes à luz da assimetria de informação, incentivos e potencial de oportunismo no acordo. A terceirização será analisada sob a luz da arquitetura organizacional dos acordos, e a variável incerteza examinará o ambiente institucional que as transações ocorrem.

\subsubsection{Estruturas de governança}

As estruturas de governança das propriedades rurais no Missouri são variadas. Existem produtores que utilizam relações contratuais para realizarem alguma atividade na propriedade e outras que são integradas verticalmente. São cinco propriedades das oito do estudo que possuem alguma atividade terceirizada na operação agrícola. Dentre elas, três propriedades, além de terceirizarem alguma atividade, também prestam serviços para terceiros.

As outras três propriedades preferem realizar todas as atividades dentro do escopo da firma. Das firmas integradas verticalmente, duas delas atuam como prestadores de serviços. $\mathrm{O}$ Quadro 9 (na página seguinte) e a Figura 12 (abaixo) mostram como as propriedades do estudo de caso são organizadas em relação às estruturas de governança das atividades produtivas. Da mesma forma que grande parte das propriedades contrata, também, cinco das oito propriedades prestam algum tipo de serviço para outros produtores rurais.

Figura 12: Estruturas de governança em propriedades rurais de soja no Missouri

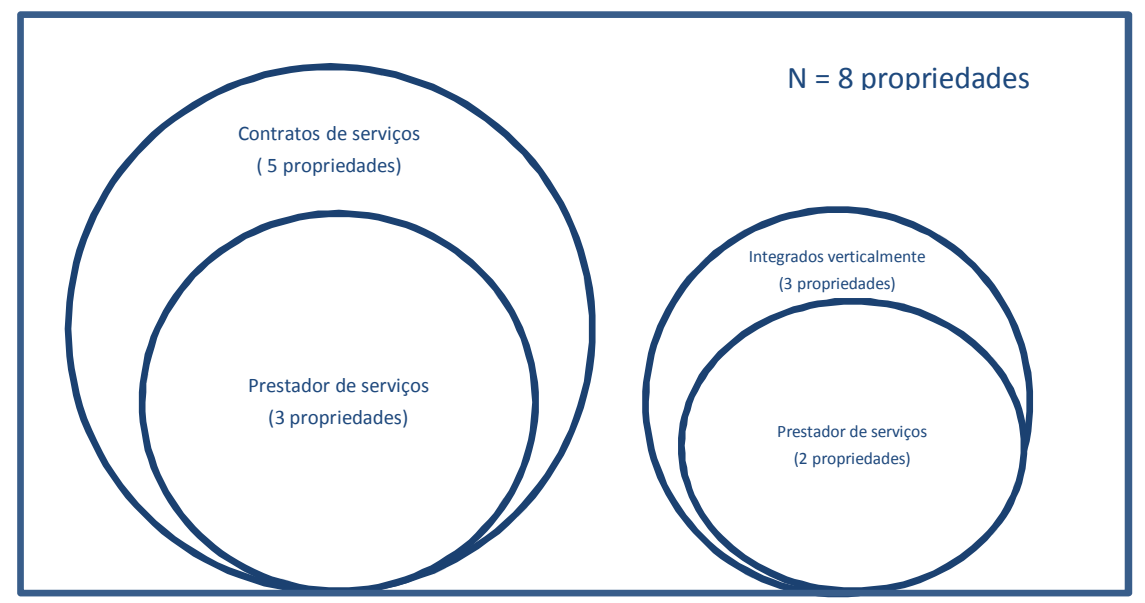

Fonte: elaborado pela autora (2019) 
Quadro 9: Terceirização nas propriedades agrícolas dos Estados Unidos

\begin{tabular}{|c|c|c|c|}
\hline Produtor & Terceiriza & Atividades terceirizadas & Presta serviços \\
\hline US1 & não & & não \\
\hline US2 & sim & $\begin{array}{c}\text { Aplicação de fertilizante } \\
\text { seco e amostragem }\end{array}$ & $\operatorname{sim}$ \\
\hline US3 & sim & $\begin{array}{c}\text { Toda operação agrícola de } \\
\text { grãos }\end{array}$ & não \\
\hline US4 & sim & Aplicação de fertilizantes & $\operatorname{sim}$ \\
\hline US5 & não & & $\operatorname{sim}$ \\
\hline US6 & não & & $\operatorname{sim}$ \\
\hline US7 & sim & Colheita profissional & não \\
\hline US8 & sim & Aplicação calcario & $\operatorname{sim}$ \\
\hline
\end{tabular}

Fonte: elaborado pela autora (2019)

As atividades mais contratadas são as que exigem algum grau de especialização, como a aplicação de fertilizantes em taxas variáveis, por meio da metodologia de agricultura de precisão. Os agricultores que contratam esse serviço expõem que, se fossem realizar esse serviço sozinhos, não teriam acesso à tecnologia de ponta e máquinas modernas como as empresas especializadas que oferecem o serviço e, se optassem por integrar tal atividade, a máquina que eles teriam acesso seria usada e inferior. As empresas que prestam esse serviço na região são empresas e cooperativas de grande porte que, além de aplicar os fertilizantes, também são atacadistas para esses produtos; logo, realizam a amostragem de solo, desenvolvem os perfis e mapas e recomendam a dosagem e aplicam.

Para mencionar algumas empresas e cooperativas na região: há a MFA Incorporated, uma cooperativa agrícola regional baseada no centro-oeste dos Estados Unidos, que atende mais de 45.000 agricultores/produtores rurais no Missouri e estados adjacentes; há a Agriservices of Brunswick LLC, atacadista e varejista de fertilizantes e um fornecedor de serviços completos para a agricultura, elevador de grãos e fornecedor de ração localizado no Centro Norte do Missouri. O serviço exige especialização e tecnologia, por isso, o 
proprietário contrata e aprova, em conjunto com a prestadora do serviço, a dosagem que será aplicada; no entanto, a recomendação e os perfis quem desenvolve e administra a aplicação é a empresa.

Outros contratos menos frequentes também são celebrados nas propriedades, são contratos com caminhões para transportar os produtos no fim da safra, terraceamento quando necessário, ou alguma demolição e construção esporádica.

Os produtores rurais do estudo de caso não contratam a pulverização de defensivos, porque grande parte deles presta esse serviço para terceiros, mas nos Estados Unidos esse é um serviço que também é terceirizado pelos produtores rurais.

A pulverização de defensivos terrestre ou aérea é um serviço especializado que exige certificação e treinamento do operador na legislação do Estado do Missouri e na maioria dos estados: “A Missouri Pesticide Use Act (Lei de Uso de pesticidas do Missouri) estabelece requisitos para o licenciamento de aplicadores, revendedores, técnicos e operadores de defensivos químicos. Há também diretrizes para aprovação de programas de treinamento de aplicadores" (Missouri Department of Agriculture, 1974, p. 6). A lei vigora desde 1974 e regula a aplicação principalmente de defensivos; segundo ela, se uma pessoa se envolver na aplicação de um pesticida de uso restrito para fins de produção de uma commodity agrícola, seja em propriedade própria ou de terceiros, com fins comerciais ou não, é necessário que essa pessoa passe por um treinamento e obtenha um licenciamento, ambos específicos, para cada categoria.

Em todos os serviços contratados, é o acordo entre o contratante e o contratado que determina o direito de decisão e direcionamento do serviço, do cronograma e dos funcionários que prestam o serviço, a depender do tipo de serviço que contratou. Em cada caso, o mix de direito de decisão e controle é diferente: pode ser o contratante que direciona e controla o serviço, ou o contratado e, em alguns casos, ambos.

Dois casos se destacaram durante as entrevistas por recorrerem à terceirização de praticamente todas as atividades agrícolas. O primeiro caso é o US7, de dois sócios, jovens agricultores, que saíram da operação da família e estão empreendendo no agronegócio há seis anos em uma propriedade de 100 hectares. Eles utilizam a capacidade ociosa de alguns equipamentos da propriedade da família e contratam colheita personalizada (custom harvesting) profissional. Apesar de existir a possibilidade de adquirir equipamentos através de financiamento do banco, gerencialmente eles acreditam que não seja prioridade no momento, uma vez que existem prestadores de serviços para a maioria das atividades. 
O produtor do US 3 tem uma grande propriedade de grãos de 2.300 hectares, porém sua atividade principal é a suinocultura e, portanto, em 1998, após ter produzido grãos e porcos 'a vida toda', segundo suas palavras, resolveu terceirizar a produção de grãos e utilizar os serviços de dois produtores rurais especializados em custom farming (agricultura personalizada). Esses produtores que prestam esses serviços de custom farming realizam todo o planejamento e as atividades em suas propriedades. $\mathrm{O}$ acordo entre as partes é que o proprietário é responsável pelos custos de sementes, químicos e fertilizantes e os prestadores de serviço sejam responsáveis pela administração das operações, equipamentos, plantio, aplicações de defensivos e fertilizantes, colheita e caminhões para transporte. A parceria deles é dividida em 70-30, 70\% da produção é do proprietário e 30\% para os produtores rurais que prestam o serviço. Os grãos são utilizados para a alimentação dos suínos e frequentemente o proprietário compra os 30\% dos grãos restantes dos prestadores do serviço.

Neste caso os produtores do custom farming têm todos os equipamentos e realizam a manutenção, a única operação que o proprietário se envolve é no transporte dos grãos para a fábrica de rações e espalhar o estrume (subproduto da produção de suínos) nas lavouras. Anteriormente ao acordo com os produtores da agricultura personalizada, a propriedade contava com um gerente de operações que era responsável por essas atividades, mas a atual estrutura adotada tem permitido focar sua atenção em se tornar mais técnico e especializado na produção de suínos. Além de terceirizar a produção agrícola de grãos na propriedade, também por vezes o proprietário contrata alguns celeiros para alojar e alimentar os porcos, os proprietários do celeiro fornecem as instalações e seguem o direcionamento em relação à alimentação em troca de uma mensalidade. Diferentemente do custom farming, nesse acordo quem direciona o serviço é o proprietário dos suínos, não os prestadores de serviços.

Além da proporção 70-30 entre proprietários e prestadores de serviços de agricultura personalizada, existem outros acordos possíveis entre proprietários e custom farming que são negociados; uma das possibilidades é, por exemplo, o 50-50, em que o prestador, além de realizar as atividades, responsabiliza-se pela compra dos insumos.

Os produtores rurais que não contratam serviços e possuem o equipamento e mão de obra para realizar os serviços não têm a intenção de contratar, no futuro, as atividades que já realizam, porque já desenvolveram o aprendizado e habilidades necessárias para desenvolvêlas.

Algumas atividades os produtores do Midwest evidenciaram que não terceirizariam. A que a maioria dos produtores do estudo de caso não consideraria contratar é o plantio, pela importância que a operação tem no resultado da safra. O plantio é uma atividade que 5 dos 8 
produtores preferem desenvolver a habilidade e ter o equipamento dentro do escopo da fazenda. As decisões sobre o plantio e práticas adotadas durante o processo têm efeito cascata sobre as outras operações e resultado na produtividade. O tratamento de sementes, a densidade de semeadura, a regulagem da plantadeira, o fio do disco de corte e, por fim, a velocidade da máquina impactam em todas as outras atividades posteriores, além da incidência de pragas e doenças ou competição de recursos no desenvolvimento da lavoura.

Outro impeditivo de por que motivo alguns talvez não optassem pela terceirização em algumas atividades foi o alto preço do serviço. A atividade de colheita encaixa-se nessa categoria, 2 produtores do estudo mencionaram que mesmo a atividade não tendo alta especificidade temporal nos Estados Unidos, o preço do serviço os faz preferir integrar a atividade. A especificidade temporal é baixa uma vez que a janela de tempo entre a colheita e o plantio é grande, o preço alto do serviço não era um atrativo para terceirizar. Mesmo assim, a colheita é uma atividade que muitos produtores optam por terceirizar nos Estador Unidos, pela sazonalidade e pelo pouco impacto na produção total.

A pulverização de agro defensivos também faz parte da categoria de atividades terceirizadas, mas que alguns preferem realizar internamente porque a janela de pulverização impacta na produção final e porque a atividade, se integrada verticalmente, gera uma economia nos custos de produção.

As diferentes atividades apresentam diferentes especificidades percebidas pelos agricultores; no entanto, o intuito do estudo de caso é focar na dimensão incerteza que o ambiente institucional pode provocar na transação, aumentando, portanto, os custos de transacionar quando comparamos ambientes institucionais distintos.

\subsubsection{Agricultores Prestadores de Serviços}

Existem os prestadores de serviços puros, como serão denominados os que não têm propriedades rurais e os agricultores prestadores de serviços. O perfil dos prestadores de serviços puros será abordado em outra seção. Nesta seção, será dada continuidade ao estudo dos produtores rurais que, além de recorrerem à terceirização em algumas atividades em suas propriedades, também atuam como prestadores de serviços. Alguns deles, além de produzirem grãos, também prestam serviços para outros agricultores na região do Missouri. Os motivos são diversos: para complementar a renda da lavoura, para aproveitar a capacidade operacional de seus equipamentos e pelo conhecimento e pela equipe que desenvolveram para as atividades. 
US8 é um pequeno produtor que decidiu integrar verticalmente a maioria das atividades; está na agricultura desde 1951, seu pai já era agricultor desde 1929, seu filho também ajuda na atividade desde que voltou do Brasil. Ele possui 200 hectares em que cultiva soja, milho, trigo e sorgo e depende de terceiros para pulverizações aéreas e serviços especializados como amostragem de solo e perfis com tecnologia de GPS, mas também presta serviços para os vizinhos. Realizam a colheita para alguns, dirige o caminhão na colheita de outro, além de realizar todos os serviços em outra propriedade a maioria das safras. Ele prefere realizar as atividades para poder controlar internamente e ajuda na vizinhança para ter uma renda extra.

O produtor de US6, além da sua propriedade de 1.300 hectares tem recursos, equipamentos e pessoal especializado, que presta serviços em 800 hectares de outras propriedades. O produtor se iniciou na agricultura por meio de parceria agrícola e equipamentos dos pais e atualmente tem suas propriedades e presta serviços. A empresa de prestação de serviços é profissionalizada, possui dois helicópteros para pulverização de defensivos, equipamento de plantio, colheitadeira, equipamento de alta tecnologia para aplicação de fertilizantes e equipe especializada. Dentro do escopo da empresa, eles têm pessoal especializado na operação e manutenção geral dos equipamentos. Um de seus funcionários possui um negócio à parte da operação, ele presta serviço de amostragem de solo, mapas e perfis do solo para que então a empresa de US6 execute a aplicação dos fertilizantes recomendados. "Para ter tudo dentro de casa é preciso ter uma escala", ele justifica.

Outro perfil de prestador de serviços é o dos irmãos da propriedade US5 que tem o negócio de Custom Farming, prestação de serviços personalizada de plantio, colheita, pulverização e, em alguns casos, de agricultura total, em que realizam todas as atividades para outros produtores rurais. Diferente da parceria agrícola (sharecroping) em que eles dividem a produção ao final, os irmãos prestam o serviço e cobram por área (no caso dos Estados Unidos, por acre). Eles explicaram que o serviço é personalizado e existem muitos tipos de acordos com os produtores contratantes, alguns contratam somente algumas atividades e outros contratam toda a operação, alguns eles somente executam a atividade, outros planejam e operacionalizam toda a produção agrícola. Atualmente eles prestam serviços em 2.000 hectares de propriedades de terceiros e possuem 300 hectares próprios. 
5.1.4.3. Prestadores de Serviços profissionalizados.

Assim como há alguns produtores rurais que prestam serviços, outros são empresas especializadas e têm na prestação de serviços uma das principais atividades. Nesta seção, serão abordadas as empresas que prestam serviços e não são formadas por produtores rurais.

\subsection{Colheita}

O empreendedor da USServicel tem 65 anos, nasceu e cresceu em uma fazenda no estado do Kansas, onde seu pai cultivava trigo e, além de realizar sua própria colheita, ajudava os vizinhos a colher. Desde pequeno, ele teve experiência na produção vegetal, porém fazendo parte de uma família de sete irmãos, acabou saindo da fazenda para prestar o serviço militar, uma vez que não seria possível todos os irmãos trabalharem na propriedade da família. Depois do serviço militar, graduou-se em Economia Agrícola, aproveitou a experiência da vivência na fazenda e resolveu começar a prestar serviços para os vizinhos da propriedade dos pais para obter renda. O pai fazia esse serviço informalmente, e ele decidiu expandir suas barreiras para prestar esse serviço especializado, o custom harvesting, ou colheita personalizada. A oportunidade ele vislumbrou quando analisou a flutuação dos preços de commodities, que sempre enfrentam altas e baixas, porém o valor do equipamento aumentava regularmente. Atualmente, ele presta dois tipos de serviços, a colheita customizada em que ele e seus funcionários realizam toda a atividade, e também aluga seu equipamento para alguns clientes.

A estrutura da empresa conta com três colheitadeiras e os trailers, os caminhões ele aluga quando tem demanda, que é sazonal na empresa. Além das máquinas, ele conta com três operadores que trabalham temporariamente na empresa. Sua empresa mantém seus equipamentos sempre atualizados e ele adquire colhedoras pouco usadas de leilões, para melhorar o resultado da sua empresa. Ele colhe em torno de 1500 hectares de grãos no Missouri, no norte de Oklahoma, sul de Kansas e uma vez também colheu no Texas.

Nos Estados Unidos, a colheita customizada (custom harvest) é um serviço amplamente adotado e os prestadores de serviços se organizam em uma associação, a United States Custom Harvesters Incorporated, ou USCHI, uma associação de profissionais colhedores profissionalizados de grãos e forragem, formada para atender às necessidades do agricultor norte-americano. A organização foi fundada em 1983 no estado do Texas e serve como um elo entre os prestadores de serviço de colheita e os muitos grupos de pessoas com 
quem trabalham, como produtores rurais, empresas, governo estadual e federal. Normalmente, uma empresa prestadora de serviços de colheita de grãos começa sua temporada em maio, cortando trigo no Texas. A equipe, em seguida, viaja para o norte até a fronteira canadense durante todo o verão e início do outono, parando no caminho para a colheita.

\subsection{Aplicação de defensivos e fertilizantes}

A USService2, LLC (limited liability company) iniciou a suas atividades no início de 1989 na parte de vendas de sementes, milho, trigo. Atualmente oferece uma ampla gama de soluções para a agricultura, além de serem 'elevadores de grão'. Atualmente são atacadistas e comerciantes de fertilizantes, armazém de grãos do estado, fornecedores de ração e possuem os serviços de aplicação customizada de defensivos e de fertilizantes líquidos e secos com tecnologia de GPS e taxa variável, além de amostragem de solos.

A USService2, LLC opera no Terminal Fluvial de Brunswick do rio Missouri. O Terminal Fluvial de Brunswick é uma instalação moderna de 48 hectares e o principal porto do Rio Missouri, com uma força de trabalho de 53 pessoas qualificadas para operar a instalação intermodal. Oferece transporte e recebimento de commodities por barcaças, trilhos e caminhões. Para a prestação de serviços, eles possuem cinco pulverizadores de defensivos de $27 \mathrm{~m}$ de largura e quatro aplicadores de fertilizantes de alta tecnologia que constantemente passam por manutenção para estarem atualizados e funcionando. Eles atendem em torno de 3,2 mil hectares para a aplicação de defensivos e quatro mil nos serviços de fertilizantes.

Ou seja, existem tanto os prestadores de perfil mais informal, que prestam o serviço como fonte de renda extra para usar o equipamento que têm, quanto o perfil de prestação de serviços mais especializado e formalizado, que oferece especialização e outras soluções para a agricultura.

\subsubsection{Valor Criado}

O valor criado nos acordos de terceirização vem da visão que os participantes do mercado têm a respeito dos benefícios que a prática traz ao negócio, assim como dos possíveis prejuízos que pode acarretar.

Entre os benefícios avaliados estão a especialização do terceiro, que pode realizar a atividade com mais qualidade e com maior eficiência do que ela ser integrada verticalmente, uma vez que, se for integrada, os talentos e habilidades de quem realiza a atividade são 
divididos em diversas áreas, e o terceiro é focado. Quando as operações são mecanizadas a manutenção do equipamento envolvido também entra em pauta, uma vez que é um custo e um tempo investidos em uma atividade que não gera diretamente retornos. Muitos agricultores buscam o serviço porque seus equipamentos antigos quebraram ou apresentaram problemas e decide não consertar ou comprar um novo equipamento. Outro motivo frequentemente citado na criação de valor da contratação de serviços é o acesso fácil a tecnologias mais modernas e recentes, visto que se fossem adquirir todo o equipamento não poderiam optar pelos mais caros e modernos.

Um ponto também citado é a rapidez que a terceirização pode trazer à atividade, uma vez que é possível realizar outras atividades enquanto a empresa terceirizada executa o serviço contratado. A falta de tempo é uma circunstância que também favorece a terceirização; na falta de disponibilidade de tempo para desenvolver alguma atividade é mais cômodo contratar. Grandes propriedades rurais não teriam tempo suficiente para realizar todas as atividades, sendo a contratação de serviços a solução para não terem que dispor de equipes muito grandes.

O número de pessoas disponíveis também é algo positivo para a contratação, se não há pessoas suficientes na propriedade ou na família, os produtores preferem que os prestadores de serviços se preocupam com a alocação de recursos humanos. O contrário também ocorre, quando na propriedade/família há pessoas suficientes e com habilidades, os produtores preferem alocar a atividade dentro da fazenda.

A economia do investimento inicial também é um ponto avaliado como benefício de não estar integrado verticalmente, uma vez que não necessita investir nos equipamentos tecnológicos com altos custos. Contudo, não só a despesa inicial foi citada, um produtor citou que apesar de muitos acharem que contratar o serviço é mais caro, a partir do momento que ele precisa de um operador essa diferença de custos de produção integrada versus o custo de produção com terceirização diminui, porque o operador de uma colheitadeira que custa meio milhão de dólares tem um salário de 100 mil dólares por ano, então, se não vão ser os próprios agricultores a operar a máquina, é preciso ter área o suficiente.

Pequenas propriedades normalmente precisam contratar por não terem escala, ou quando não há pessoas suficientes para executar todas as atividades. Alguns fazendeiros não têm a agricultura como única fonte de renda e trabalham em outros empregos em determinados períodos do ano; logo, não têm tempo de realizar tudo sozinhos e se torna mais conveniente contratar alguém. Grandes produtores também optam por não terem tantas pessoas trabalhando na propriedade rural e terceirizam atividades; um dos entrevistados citou 
um amigo que tem milhares de hectares e contrata a pulverização de empresas especializadas, que ele não acredita em economia ao integrar verticalmente e também prefere contratar quando tem a demanda que ter um equipamento parado e depreciando no galpão e um funcionário extra para aplicar os defensivos.

A terceirização, porém, apresenta também aspectos negativos na percepção dos produtores rurais, o que no balanço custo-benefício pode levar muitos a optar pela integração vertical. O maior inconveniente citado foi o preço do serviço prestado, que quando computado e comparado é maior do que realizar a atividade dentro do escopo da firma. Um produtor afirmou que "toda vez que está terceirizando está dando lucro a alguém" para explicar o ponto de vista dele. Outro disse que ele terceirizou e pretende integrar novamente a atividade, pois "ficou mil dólares mais caro do que se ele mesmo tivesse realizado a atividade em uma área de 75 hectares".

Mais um dos pontos negativos muito citados é o cronograma, sendo que a disponibilidade do prestador de serviços é diferente muitas vezes da necessidade do produtor rural. Quando a atividade é integrada verticalmente, o produtor não está sujeito a atrasos no cronograma e pode realizar a atividade assim que tiver a demanda. Quando contrata, precisa coincidir a execução da atividade com a empresa estar disponível, e esperar muitas vezes significa ou ter mais despesas com produtos químicos no caso de pragas e doenças ou perda de produtividade devido à especificidade temporal do ativo.

Por fim, ter que monitorar e verificar a performance da atividade é uma das motivações a realizarem eles mesmos a atividade, pois "preferem que seja feito de determinada forma então optam pelo $M A K E$ (fazer) ao invés do BUY (contratar) ".

No estudo de caso dos Estados Unidos, quando o balanço do valor criado por meio dos benefícios da terceirização comparados a possíveis problemas de não controlar os ativos, há um resultado positivo. Os agricultores foram perguntados livremente sobre motivos para contratar e para não contratar, então um índice foi construído mediante a diferença de motivos levantados para terceirizar (positivos a favor da terceirização) e motivos para não terceirizar (negativos à terceirização) uma atividade. A construção deste índice permitiria ter um resultado de valor negativo, caso no estudo de caso, houvesse mais motivos negativos para terceirizar uma atividade do que motivos positivos, os índices de cada um dos casos são apresentados no Quadro 10 (vide página seguinte), o resultado dos Estados Unidos foi um índice médio de 0,66 , sendo que a grande parte dos produtores rurais que vê valor criado positivo, ou seja, mais benefícios do que desvantagens na terceirização, contrata serviços de 
terceiros. Os casos US5 e US6 veem valor e não terceirizam, isso porque eles se enquadram na categoria de produtores rurais prestadores de serviços.

Quadro 10: Percepção norte-americana de valor criado na terceirização de atividades.

\begin{tabular}{|c|c|c|}
\hline Produtor & Terceiriza & Valor Criado \\
\hline US1 & não & -1 \\
\hline US2 & sim & 0 \\
\hline US3 & $\operatorname{sim}$ & 1 \\
\hline US4 & $\operatorname{sim}$ & 1 \\
\hline US5 & não & 3 \\
\hline US6 & não & 0 \\
\hline US7 & sim & 1 \\
\hline US8 & sim & 0 \\
\hline
\end{tabular}

Fonte: elaborado pela autora (2019)

\subsubsection{Incerteza e Risco}

Quando se opta por contratar algum serviço, além de estar cedendo o direito de decisão e o controle de como a atividade será desempenhada, o produtor também não é mais responsável pelos efeitos que a atividade pode ocasionar; uma vez que ele não tem mais controle sobre os riscos da atividade, ele não responde mais pelos efeitos como, por exemplo, a deriva de defensivos em propriedades vizinhas.

A terceirização, e contratação de serviços nos Estados Unidos não tem legislação específica, se enquadrando na área de direito contratual. A responsabilidade civil pelos atos de terceiros também não se encontra definida em nenhuma legislação nos Estados Unidos como corresponsabilidade do contratante. Ela segue a legislação 'comum' dos contratos, respeitando o que está definido entre as partes, e o contratante torna-se responsável somente caso exista alguma negligência de sua parte como, por exemplo, ao prestar alguma informação ou ordenar alguma atividade que apresente risco conhecido e não reportado. No 
entanto, situações imprevistas podem ocorrer e podem causar disputas, caso não haja consenso entre as partes em alguma ocorrência.

Contudo, mais importante que a alocação da responsabilidade entre as partes é a percepção dessa alocação e os riscos que a empresa enfrenta ao contratar um serviço sem controlá-lo. Além do risco, a incerteza de como essas disputas serão resolvidas; caso esses tipos de situações surjam, também afeta a tomada de decisão. Se a percepção das partes é que a alocação de riscos nas resoluções dos tribunais causa incerteza no ambiente de negócios e que elas possam vir a ser responsabilizadas e prejudicadas pelos erros de terceiros sem ter alguma gerência (atuação) sobre eles, é mais provável que evitem contratar atividades de terceiros.

Os agricultores foram questionados a respeito da responsabilidade civil (liability) em situações de risco como: i) 'de quem é a responsabilidade se um funcionário da empresa contratada (terceirizada) se machuca na sua propriedade?', ii) 'de quem é a responsabilidade se um funcionário de empresa contratada pulverizar a propriedade do vizinho?', iii) 'se a empresa terceirizada não paga o salário ou impostos a seus funcionários durante o período que está prestando serviços para você; quem é responsável se o caso for para os tribunais?', e iv) 'se a empresa terceirizada não respeita as leis sobre tempo extra e salários mínimos, quem é responsável por isso?'. Os resultados de disputas judiciais dessa natureza podem influenciar na tomada de decisão sobre contratar ou integrar verticalmente uma atividade na operação.

A percepção sobre a questão da responsabilidade sobre a lesão de funcionário de terceiros ao prestar o serviço na propriedade foi o único que causou divergência de opiniões entre os produtores no Missouri. Dos produtores rurais dos estudos de casos, dois não têm certeza do que ocorre se alguma disputa do gênero parasse nos tribunais, dois acreditam que exista algum tipo de responsabilidade (corresponsabilidade) do proprietário da terra e contratante e cinco entendem que se o funcionário se machucou em atividades normais que executa para o terceiro a responsabilidade civil é da empresa prestadora de serviços e não do contratante do serviço. Os dois prestadores de serviços entrevistados também entendem que a responsabilidade é da empresa que presta o serviço, no caso eles próprios.

Nas questões que dizem respeito ao dano causado às propriedades vizinhas durante a prestação de serviços, do não pagamento de salários e/ou impostos aos funcionários e do não respeito às legislações trabalhistas todos os nove agricultores têm certeza de que a responsabilidade civil é de quem está desempenhando a atividade: o prestador de serviços. $\mathrm{E}$ os dois prestadores de serviço também concordam com essa responsabilidade, deixando pouco espaço para a incerteza quanto à responsabilidade civil ao contratar um serviço. 
Os prestadores de serviços, quando questionados sobre as situações, foram categóricos ao assumirem a responsabilidade por qualquer problema causado na prestação de serviços, a menos que haja negligência do produtor contratante ou alguma informação ocultada. Os dois prestadores de serviços profissionais deram ênfase aos seguros que protegem as partes no caso de incidentes de trabalho que possam causar lesão aos funcionários: além de os funcionários terem que possuir seguro, a empresa também possui seguro abrangente (comprehensive insurance) e seguro de responsabilidade civil (personal liability insurance).

Mesmo alguns tendo deixado de contratar ou prestar serviços por acreditarem que poderiam ser responsabilizados judicialmente caso algum problema ocorresse, os relatos são de situações sabidamente arriscadas e potencialmente perigosas, como: transporte em regiões e estradas danificadas que poderiam causar acidentes, a pulverização de defensivos quando as condições são perigosas ou o defensivo tem potencial de deriva alto e pode, portanto, prejudicar os vizinhos, como é o caso do Dicamba (herbicida com potencial para controlar as invasoras de folhas largas resistentes ao glifosato, que pode prejudicar vizinhos que não têm a tecnologia da semente resistente ao ativo). Ainda cientes dos perigos, não deixaram de contratar por receio de serem responsabilizados por erros de terceiros.

Para reforçar essa questão dos riscos e incerteza mais questões foram propostas com esse intuito, questões como: 'se você contratasse um prestador de serviços independente e ela enfrentasse problemas legais enquanto prestando serviços para você, você seria responsabilizado na justiça?' e, 'se você fosse processado legalmente devido a um problema do prestador de serviços você acredita que seria considerado culpado?' foram feitas usando uma escala likert de cinco pontos.

Ambas as questões têm resposta média positiva como mostra a Tabela 9, significando que os respondentes não acreditam que seriam responsabilizados por erros, problemas e negligência de terceiros, mesmo enquanto prestando serviços em suas propriedades, uma vez que os resultados de 3,27 estão acima do ponto de neutralidade da escala likert para esta pergunta (2,5 de 5 pontos).

Tabela 9: Responsabilidade ao contratar terceiros

\begin{tabular}{|l|c|c|}
\hline Responsabilidade & Resultado médio & Desvio Padrão \\
\hline $\begin{array}{l}\text { Seria responsabilizado nos tribunais por } \\
\text { negligencia ou erro da empresa terceirizada. }\end{array}$ & 3,27 & 1,01 \\
\hline $\begin{array}{l}\text { Seria culpado caso fosse processado por } \\
\text { problema da empresa terceirizada. }\end{array}$ & 3,27 & 0,90 \\
\hline $\begin{array}{l}\text { Fonte: elaborado pela autora (2018) } \\
\text { (20) }\end{array}$
\end{tabular}




\subsubsection{Sistema judiciário nos Estados Unidos}

O sistema judiciário é um componente do ambiente institucional que é responsável por garantir que as leis e regulamentações sejam interpretadas, aplicadas e cumpridas. Os primeiros sistemas legais do mundo foram criados para garantir que os cidadãos resolvessem conflitos sem violência; atualmente seu papel é muito mais amplo. Um exemplo de como o sistema judiciário e a qualidade do Estado de Direito podem influenciar o ambiente de negócios é dado a seguir:

Suponha-se um investidor buscando investir recursos no exterior. Ele, provavelmente, pensaria duas vezes antes de investir em um país onde a corrupção é desenfreada, os direitos de propriedade são mal definidos e os contratos são difíceis de serem cumpridos. A aplicação desigual de regulamentos, corrupção, incerteza dos direitos de propriedade e meios ineficazes para resolver disputas prejudicam negócios legítimos e impedem investimentos. Logo, as ações que o sistema judiciário adota e a percepção que as partes têm da incerteza nesse sistema conduzem a diferentes escolhas e diferentes padrões de estruturas de governança.

\subsubsection{Intervenções judiciais}

Intervenções judiciais podem mudar a estratégia de algumas empresas. Cumpre destacar que foram elas que motivaram, inicialmente, o estudo do sistema judiciário afetando as estruturas de governança das firmas.

Os produtores do estudo de caso já souberam de intervenções judiciais, porém nenhuma que envolvesse terceiros e prestação de serviços. Em primeiro lugar porque nos Estados Unidos os agricultores têm algumas isenções de legislações uma vez que a atividade tem particularidades, eles são isentos, por exemplo, de pagamento de horas extras e não costumam ter muitos problemas trabalhistas. Em segundo lugar porque qualquer erro que venha a acontecer será resolvido ou pelo sistema judiciário ou pelas seguradoras. Os produtores rurais têm seguros de responsabilidade civil, entre outros, para garantir que o negócio esteja protegido caso algum problema ocorra. Usando como exemplo a situação com a deriva do Dicamba, problema que tem sido frequente nos EUA, de contaminação e perdas nas lavouras dos vizinhos, caso ocorra o dano, a seguradora faz um acordo e a questão não chega a ir para a corte para ser resolvida.

Um dos agricultores que presta serviços discorreu que "se abordar com integridade e principios morais, se for correto não passará por problemas judiciais. Se tem uma boa reputação, 
histórico, não terá problemas ao longo da trajetória, porque haverá muitas pessoas dispostas a testemunhar positivamente ao seu favor se algum incidente ocorrer".

\subsubsection{Percepção do sistema judiciário nos Estados Unidos}

O estudo baseia-se na influência do sistema judiciário na tomada de decisões sobre a estrutura de governança na agricultura. Logo, a percepção que os agentes têm do sistema judiciário é uma categoria importante para comparação posterior da diferença de comportamento e decisões entre os países. Os agricultores opinaram sobre os atributos do sistema judiciário, sobre a confiança que têm em mecanismos de resolução de disputas e sobre decisões das cortes em disputas que envolvem prestadores de serviços.

O sistema judiciário é a ramificação do governo que é dotado da autoridade para interpretar e aplicar a lei, julgar disputas legais e, de outra forma, administrar a justiça. $\mathrm{O}$ judiciário dos EUA compreende um sistema de tribunais estaduais e federais, tribunais e órgãos administrativos, bem como os juízes e outros funcionários judiciais que os presidem. O sistema judiciário faz parte do ambiente institucional e tem um importante papel na resolução de disputas. Nos Estados Unidos o sistema judiciário é o common law (ou direito comum), nesse sistema, as leis baseiam nas decisões dos juízes e nos costumes, e não nas leis escritas.

O sistema judiciário pode ser medido pela qualidade de seus processos que englobam o tempo de resolução de disputas, pelo custo envolvido nessas resoluções a burocracia e pela facilidade de acesso ao sistema. Os agricultores e prestadores de serviços foram confrontados com questões sobre esses atributos para responder por meio de uma escala likert de 5 pontos, conforme pode ser verificado no instrumento do estudo de casos. Esses resultados são apresentados de maneira consolidada para o sistema judiciário norte-americano, ou seja, como um resultado médio da percepção de todos os produtores do estudo de caso. Os resultados podem ser verificados na Tabela 10 (vide página seguinte), que possui o resultado médio e o desvio padrão da percepção que eles têm a respeito dos atributos, sendo que na escala quanto maior o resultado melhor a percepção de qualidade deles. 
Tabela 10: Atributos do Sistema Judiciário dos Estados Unidos

\begin{tabular}{|l|c|c|}
\hline Atributos Sistema judiciário & Resultado médio & Desvio Padrão \\
\hline $\begin{array}{l}\text { Qualidade judicial satisfatória (tempo, custo, } \\
\text { acesso, previsibilidade, imparcialidade) }\end{array}$ & 3,82 & 1,08 \\
\hline Rapidez/tempo na solução de disputas & 1,91 & 0,70 \\
\hline Custo de utilizar o sistema judiciário & 2,09 & 1,30 \\
\hline Burocracia do sistema judiciário & 2,09 & 0,83 \\
\hline Acesso ao sistema judiciário & 3,64 & 1,29 \\
\hline
\end{tabular}

Fonte: elaborado pela autora (2018)

A percepção geral da qualidade judicial tem um resultado positivo nos Estados Unidos. Os agentes percebem que, no todo, o sistema judiciário é satisfatório; o resultado foi 3,82 , resultado acima do ponto de neutralidade, com uma dispersão de 1,08 , desvio padrão em torno da média, com nenhum resultado de 'discordo totalmente' da qualidade satisfatória do sistema judiciário.

Os atributos custo de utilizar o sistema e a burocracia obtiveram resultados abaixo do ponto neutro da escala likert, este resultado foi discrepante do anterior sendo que essas questões deveriam formar a qualidade satisfatória do sistema judiciário; no entanto, podem ter levado em conta os atributos que foram considerados na confiança nos tribunais e no acesso ao sistema. O resultado do tempo na solução de disputas foi o que apresentou o pior resultado, de 1,91, bem como apresentou também o menor desvio padrão e o cuto e burocracia tiveram resultado 2,09 .

Quanto ao acesso ao sistema, o resultado foi acima do ponto de neutralidade, 3,64, o que mostra que os participantes acreditam que é simples acessar o sistema judiciário. Contudo, quando a questão é sobre que mecanismo de resolução de disputas, os respondentes confiariam primeiro ao tentar resolver uma disputa; nenhum deles citou que as cortes e juízes seriam sua primeira opção. Decisão que é consistente com eles acharem o sistema judiciário caro, moroso e burocrático. A primeira opção que os participantes tentariam, após tentar resolver o problema entre as partes, seria a mediação (seis dos 11 respondentes), seguido pela arbitragem (um respondente), os demais respondentes disseram que não recorreriam a nenhuma das opções (quatro respondentes).

A confiança que as partes têm nos mecanismos de resolução de conflitos é o outro ponto investigado, bem como a imparcialidade dos tribunais e quanto tempo os tomadores de decisão confiam que o tribunal faz o que é certo. 
Nessas categorias, a escala likert foi de 4 pontos, para evitar o ponto neutro, com exceção da questão do tempo. Os resultados são vistos na Tabela 11.

Tabela 11: Grau de confiança nos mecanismos de solução de disputas

\begin{tabular}{|c|c|c|}
\hline Grau de Confiança ${ }^{1}$ & Resultado médio & Desvio Padrão \\
\hline Confiança mediação & 3,09 & 0,54 \\
\hline Confiança arbitragem & 2,55 & 0,69 \\
\hline Confiança tribunais e juízes & 3,00 & 0,89 \\
\hline Confiança na imparcialidade dos tribunais & 2,91 & 0,83 \\
\hline $\begin{array}{l}\text { Quanto do tempo confia nos tribunais* } \\
{ }^{1} \text { : escala likert de } 4 \text { pontos } \\
* \text { escala likert de } 3 \text { pontos }\end{array}$ & 1,91 & 0,83 \\
\hline Fonte: elaborado pela autora (2018) & & \\
\hline
\end{tabular}

O mecanismo que tem o maior grau de confiança foi a mediação, com média 3,09 dos 4 pontos possíveis, resultado que corrobora a questão de que mecanismo de solução de disputas os participantes primeiramente recorreriam. Os tribunais e juízes vieram em seguida, com média 3 no grau de confiança e dispersão 0,89 ; por último, o grau de confiança mais baixo, porém ainda positivo, foi encontrado no quesito 'mecanismo de arbitragem', com média 2,55 .

Os resultados também apresentam um grau de confiança positivo na imparcialidade das decisões judiciais, 2,91 a resposta média, ou seja, eles não acreditam que haja favorecimento das cortes nas decisões das disputas judiciais.

Para confirmar o grau de confiança nas cortes, foi perguntado quanto do tempo confiavam que os tribunais faziam o que era certo e a resposta média foi 1,98 (sendo que 3 é o resultado máximo particularmente nesta questão).

Os resultados da percepção do sistema judiciário dos Estados Unidos pelos agricultores e prestadores de serviços são positivos, mostrando que além de acreditarem que o sistema tem qualidade satisfatória, os participantes confiam nos tribunais, bem como em outros mecanismos de disputas. Portanto, essa percepção de qualidade e confiança no sistema judiciário tem uma influência positiva no ambiente de negócios, não se tornando esse componente do ambiente institucional um impeditivo para as partes celebrarem contratos entre si. 


\subsubsection{Conclusão}

Nos Estados Unidos, os produtores que optam pela terceirização, o fazem como uma escolha estratégica. Eles escolhem a opção pela desintegração vertical das operações para ter acesso a novas tecnologias e acesso a serviços especializados, como a aplicação de fertilizante em taxas variáveis, terceirizam para não dividirem sua atenção com atividades sem especificidade de ativos ou realizadas em baixa frequência e ainda para não perderem o foco de atividades que julgam vitais estarem dentro do escopo da firma. Alguns ainda optam por terceirizar toda a produção, para que se concentrem na atividade principal que não é de grãos.

O Quadro 11 mostra um resumo das variáveis que constroem a arquitetura organizacional de cada caso discutido dos Estados Unidos.

Quadro 11: Tomada de decisão dos produtores rurais dos Estados Unidos.

\begin{tabular}{|c|c|c|c|c|c|c|c|}
\hline \multirow[b]{2}{*}{ Produtor } & \multicolumn{2}{|c|}{ DIREITO DECISÃO } & \multirow{2}{*}{$\begin{array}{c}\text { VALOR } \\
\text { Valor Criado }\end{array}$} & \multicolumn{4}{|c|}{ Fatores que afetam a INCERTEZA } \\
\hline & Terceiriza & Presta serviços & & $\begin{array}{c}\text { Qualidade e } \\
\text { Confiança no } \\
\text { Sistema Judicial }^{1}\end{array}$ & $\begin{array}{c}\text { Corresponsabilidade } \\
\text { judicial }\end{array}$ & $\begin{array}{c}\text { Já deixou de contratar } \\
\text { por responsabilidade } \\
\text { judicial }\end{array}$ & $\begin{array}{c}\text { Responsabilizado } \\
\text { judicialmente por erro de } \\
\text { terceiros prestando } \\
\text { serviço na propriedade } \\
\end{array}$ \\
\hline US1 & não & não & -1 & 2,8 & não & não & 3 \\
\hline US2 & $\operatorname{sim}$ & $\operatorname{sim}$ & 0 & 3,7 & não & $\begin{array}{c}\text { sim, em atividades } \\
\text { arriscadas fora da } \\
\text { agricultura }\end{array}$ & 4,5 \\
\hline US3 & $\operatorname{sim}$ & não & 1 & 2,4 & $\begin{array}{c}\text { corresponsabilidade } \\
\text { somente para lesão }\end{array}$ & & 3 \\
\hline US4 & $\operatorname{sim}$ & $\operatorname{sim}$ & 1 & 3,3 & $\begin{array}{l}\text { não, sem certeza } \\
\text { para lesão }\end{array}$ & não & 3 \\
\hline US4 & $\operatorname{sim}$ & $\operatorname{sim}$ & 1 & 2,2 & $\begin{array}{l}\text { não, sem certeza } \\
\text { para lesão }\end{array}$ & não & 4,5 \\
\hline US5 & não & $\operatorname{sim}$ & 3 & 2,8 & não & \begin{tabular}{|c|}
$\begin{array}{c}\text { sim, deixou de prestar } \\
\text { serviços por causa do } \\
\text { risco }\end{array}$ \\
\end{tabular} & 2 \\
\hline US6 & não & $\operatorname{sim}$ & 0 & 3,9 & não & $\operatorname{sim}$ & 3,5 \\
\hline US7 & $\operatorname{sim}$ & não & 1 & 2,8 & $\begin{array}{c}\text { corresponsabilidade } \\
\text { somente para lesão }\end{array}$ & não & 3,5 \\
\hline US8 & $\operatorname{sim}$ & $\operatorname{sim}$ & 0 & 3,5 & não & $\begin{array}{c}\text { sim, deixou de prestar } \\
\text { serviços por causa do } \\
\text { risco }\end{array}$ & 3,5 \\
\hline
\end{tabular}

Fonte: elaborado pela autora (2019)

Os produtores não se preocupam com problemas legais e judiciais ao tomarem essa decisão, mesmo sem contratos eles acreditam que se alguma disputa surgir o resultado das cortes deve ser, na maioria das vezes, justo e imparcial. A percepção geral dos produtores é a de que o sistema judiciário norte-americano tem qualidade satisfatória para resolver quaisquer acontecimentos inesperados como acidentes, efeitos adversos e problemas de hold up, além de 
que os produtores rurais nos Estados Unidos contam com algumas proteções e isenções em relação a leis, como a de horas extras, uma vez que a atividade agrícola não pode parar durante fins de semanas e feriados.

Outro fator que coopera para esse cenário são mecanismos particulares de resolução de conflitos e de transferência de riscos. Os seguros disponíveis transferem certos riscos para as seguradoras, os produtores não se preocupam com problemas com terceiros porque os seguros de responsabilidade civil disponíveis também na atividade agrícola cobrem possíveis danos e acidentes que possam surgir dessas relações, desde que não haja negligencia das partes; nesse caso, é preciso recorrer a outros meios de solução.

A mediação e a arbitragem são alternativas aos tribunais e os produtores têm conhecimento das vantagens que eles podem trazer ao ambiente de negócios, agilizando o tempo de resolução e auxiliando as partes a chegarem a um acordo.

Em vista disso, o ambiente institucional, o sistema judiciário e até mesmo os mecanismos alternativos de solução de disputas e transferências de risco cooperam para que a incerteza seja diminuída e, por consequência, também os custos de transação. Dessa forma, os agentes sentem-se seguros para buscar recursos e serviços no mercado e por meio de contratos.

\subsection{Terceirização de serviços na agricultura do Brasil}

\subsubsection{Introdução}

O agronegócio brasileiro é sabidamente um importante na economia nacional, com o PIB do agronegócio em 2018 estimado em U\$S 372,1 bilhões de dólares (R \$ 1,44 trilhões de reais) em valores correntes, e corresponde a $21 \%$ do produto interno bruto brasileiro de U\$S 1,77 trilhões, sendo a agropecuária responsável por U\$S 90,80 bilhões de dólares ( $\mathrm{R} \$ 351,43$ bilhões de reais), ou seja, 5,1\% do PIB total do Brasil, conforme mostra o Gráfio 4, na página seguinte.

O censo agropecuário 2017 do Brasil mostra que existem 350 milhões de hectares de dedicados à produção agropecuária no País, distribuídos em cinco milhões de propriedades rurais que empregam 15 milhões de pessoas em atividades agropecuárias. 


\section{Gráfico 4: Participação do agronegócio no Produto Interno Bruto no Brasil}

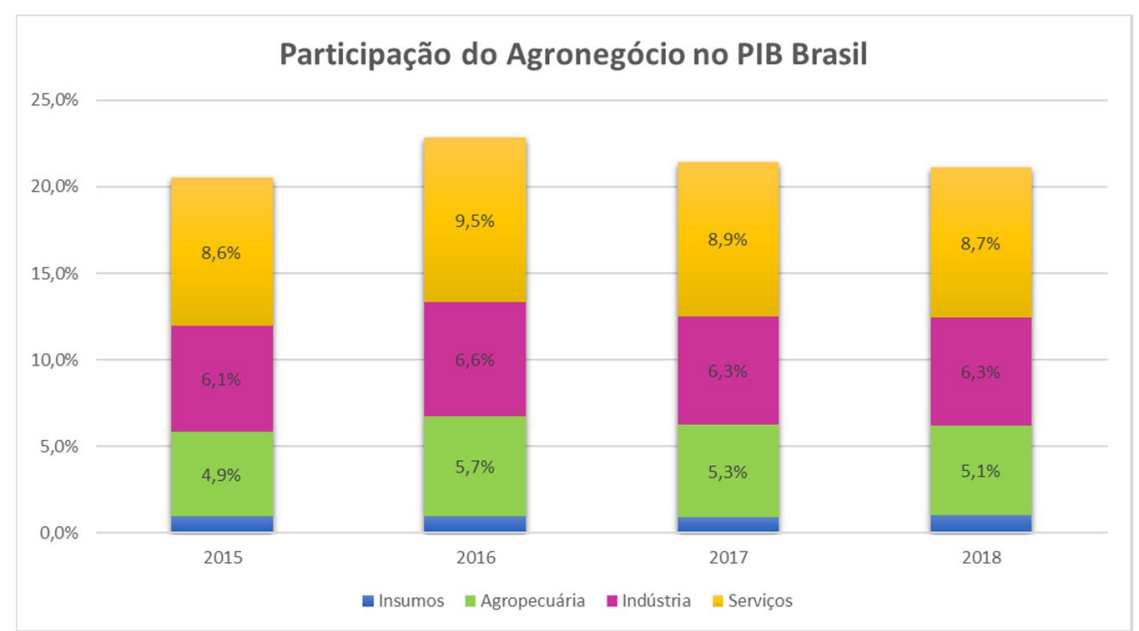

Fonte: elaborado pela autora, com base no Centro de Estudos Avançados em Economia Aplicada (2018)

$\mathrm{Na}$ economia brasileira, o comércio de produtos agrícolas é importante fonte de geração de valor; em 2017, as exportações foram de U\$S 96 bilhões de dólares, o que representa $41 \%$ de todas as exportações brasileiras. A balança comercial brasileira tem um superávit de U\$S 66 bilhões, enquanto a balança comercial do agronegócio apresenta um superávit de U\$S 81 bilhões de dólares (Ministério da Agricultura, Pecuária e Abastecimento, 2018). No mundo, o Brasil ocupa o terceiro lugar na lista dos maiores exportadores de commodities do mundo, ficando atrás somente da União Europeia e dos Estados Unidos, segundo relatório da Organização das Nações Unidas para a Agricultura e Alimentação. Os produtos agrícolas mais exportados são soja, açúcar, café verde, carnes, tabaco, suco de laranja e algodão, conforme a Tabela 12, a seguir: 
Tabela 12: Exportação de Commodities do Brasil

\begin{tabular}{|rl|r|r|}
\hline Ranking & Item & $\begin{array}{c}\text { Valor } \\
(1000 \text { U\$S) }\end{array}$ & $\begin{array}{r}\text { Quantidade } \\
\text { (toneladas) }\end{array}$ \\
\hline 1 & Soja & 19.331 .323 & 51.581 .875 \\
\hline 2 & Açucar cru & 8.282 .168 & 23.660 .982 \\
\hline 3 & Carne de frango & 5.946 .161 & 3.959 .394 \\
\hline 4 & Soja (torta) & 5.192 .781 & 14.443 .792 \\
\hline 5 & Café verde & 4.843 .001 & 1.823 .886 \\
\hline 6 & Carne, bovinos sem ossos & 4.327 .806 & 1.068 .628 \\
\hline 7 & Milho & 3.739 .923 & 21.873 .310 \\
\hline 8 & Açucar refinado & 2.153 .676 & 5.271 .957 \\
\hline 9 & Tabaco não manufaturado & 2.054 .089 & 466.300 \\
\hline 10 & Suco laranja concentrado & 1.431 .259 & 885.448 \\
\hline 11 & Carne de porco & 1.290 .564 & 590.805 \\
\hline 12 & Algodão & 89.215 .457 & 804.802 \\
\hline 13 & Óleo de soja & 568.304 & 1.254 .185 \\
\hline 14 & Carne, frango, enlatado & 482.461 & 212.549 \\
\hline 15 & Suco de laranja (single strength) & 399.896 & 1.429 .231 \\
\hline 16 & Carne seca em pó & 181.500 \\
\hline
\end{tabular}

Fonte: Food and Agriculture Organization of the United Nations (2018)

O valor bruto da produção de commodities agrícolas pode ser verificado na Tabela 13 e revela as commodities mais importantes no Brasil, os grãos soja e milho têm, juntos, um valor bruto da produção (VBP) de U\$S 48,94 bilhões (R\$ 189,4 bilhões), sendo a soja a cultura mais importante; a cana-de-açúcar apresenta um VBP de U\$S 15,78 bilhões de dólares (61 bilhões de reais); depois, em ordem de valores brutos, há o algodão e o café, com 8,7 e 6,4 bilhões de dólares (33 e 24 bilhões de reais), respectivamente, e a laranja, com 3,2 bilhões de dólares (12 bilhões de reais). 
Tabela 13: Valor Bruto da Produção Agrícola no Brasil

\begin{tabular}{|c|c|c|c|c|c|}
\hline \multicolumn{6}{|c|}{$\begin{array}{l}\text { VALOR BRUTO DA PRODUÇÃO - LAVOURAS E PECUÁRIA - BRASIL } \\
\text { Valores em U\$Sं* }\end{array}$} \\
\hline LAVOURAS & 2015 & 2016 & 2017 & 2018 & Gráficos \\
\hline Algodão herbáceo & 3.850 .026 .609 & 4.162 .235 .426 & 7.039.738.417 & 8.782 .512 .053 & \\
\hline Amendoim & 309.405 .697 & 413.858 .554 & 419.165 .987 & 324.022 .962 & \\
\hline Arroz & 3.065.786.999 & 3.342.093.206 & 3.581 .953 .836 & 2.552.725.651 & \\
\hline Banana & 2.802.041.942 & 4.913.207.639 & 3.537.293.434 & 2.636.309.289 & \\
\hline Batata - inglesa & 1.696 .635 .406 & 2.434 .326 .631 & 1.282 .754 .882 & 1.047.998.944 & \\
\hline Cacau & 403.602 .648 & 626.647 .785 & 447.900 .719 & 519.324 .046 & \\
\hline Café & 5.746 .015 .483 & 8.164 .414 .667 & 6.839.257.725 & 6.440 .662 .939 & \\
\hline Cana-de-açúcar & 14.714 .444 .978 & 18.407.388.999 & 22.118.997.071 & 15.784 .016 .690 & \\
\hline Cebola & 894.687 .107 & 1.214 .360 .731 & $602.864 .681-$ & & \\
\hline Feijão & 2.433 .495 .658 & 3.744 .218 .150 & 2.694 .483 .837 & 1.489 .786 .697 & \\
\hline Fumo & 2.232.388.877 & 1.887.061.759 & - & - & \\
\hline Laranja & 3.346 .627 .055 & 4.249 .786 .680 & 4.637.977.056 & 3.217.810.399 & \\
\hline Mamona & 19.152 .180 & 14.983 .503 & 8.923 .203 & 12.454 .483 & \\
\hline Mandioca & 2.124.407.094 & 2.126.092.275 & 3.910 .559 .538 & 2.525.216.311 & \\
\hline Milho & 12.183 .670 .799 & 13.795 .276 .885 & 15.551 .885 .075 & 12.175 .328 .738 & \\
\hline Pimenta-do-reino & 391.309 .969 & 447.741 .429 & 439.937 .923 & - & \\
\hline Soja & 31.933 .776 .675 & 38.269.920.152 & 38.370 .837 .592 & 36.785 .261 .155 & \\
\hline Tomate & 4.258.226.658 & 2.890 .726 .441 & 2.681.349.095 & 2.423.082.971 & \\
\hline Trigo & 1.058.137.553 & 1.649 .476 .563 & 823.058 .152 & 1.134.045.915 & \\
\hline Uva & 1.102 .865 .750 & 1.144.256.519 & 1.852 .679 .879 & 1.342.078.197 & \\
\hline Maçã & 1.080 .100 .320 & 1.435 .406 .808 & 1.106.266.663 & - & \\
\hline TOTAL LAVOURAS & 95.646.805.457 & 115.333 .480 .802 & 117.947.884.765 & 99.192.637.443 & \\
\hline Bovinos & 21.517.902.394 & 23.984.200.958 & 23.109.709.476 & 19.732.297.264 & \\
\hline Suínos & 4.350 .443 .918 & 4.780 .732 .465 & 5.210 .904 .782 & 3.610.029.852 & \\
\hline Frango & 14.878 .823 .674 & 18.052 .651 .947 & 16.144.771.702 & 13.749 .313 .675 & \\
\hline Leite & 8.157.869.493 & 9.013 .608 .459 & 9.860 .966 .745 & 8.254.393.747 & \\
\hline Ovos & 3.523.615.996 & 4.523.398.265 & 3.660 .865 .990 & 2.707.295.600 & \\
\hline TOTAL PECUÁRIA & 52.428.655.474 & 60.354.592.094 & 57.987.218.695 & 48.053.330.139 & \\
\hline VBP TOTAL & 148.075 .460 .931 & 175.688 .072 .895 & 175.935 .103 .460 & 147.245.967.581 & \\
\hline
\end{tabular}

Fonte: Consolidado pelo Ministério da Agricultura de IBGE (2018), CEPEA (2018), CONAB (2018)

* Valores deflacionados pelo IGP-DI da FGV (dez/2018) e convertidos para dólar do respectivo ano.

O Brasil é o primeiro produtor e exportador de várias commodities, incluindo de grãos (soja e milho) e o suco de laranja, commodities que serão abordadas no estudo de caso do País, a primeira uma lavoura temporária e a outra perene, uma vez que são importantes para o País e também porque, por terem características diferentes, apresentam tratos culturais e atividades distintas. Outras culturas também serão abordadas, uma vez que os produtores rurais do Brasil diversificam as atividades agropecuárias em suas propriedades. O Gráfico 5 e o Gráfico 6 (vide página seguinte), mostram que o Brasil figura como principal exportador das commodities do estudo. 
Gráfico 5: Países exportadores de soja

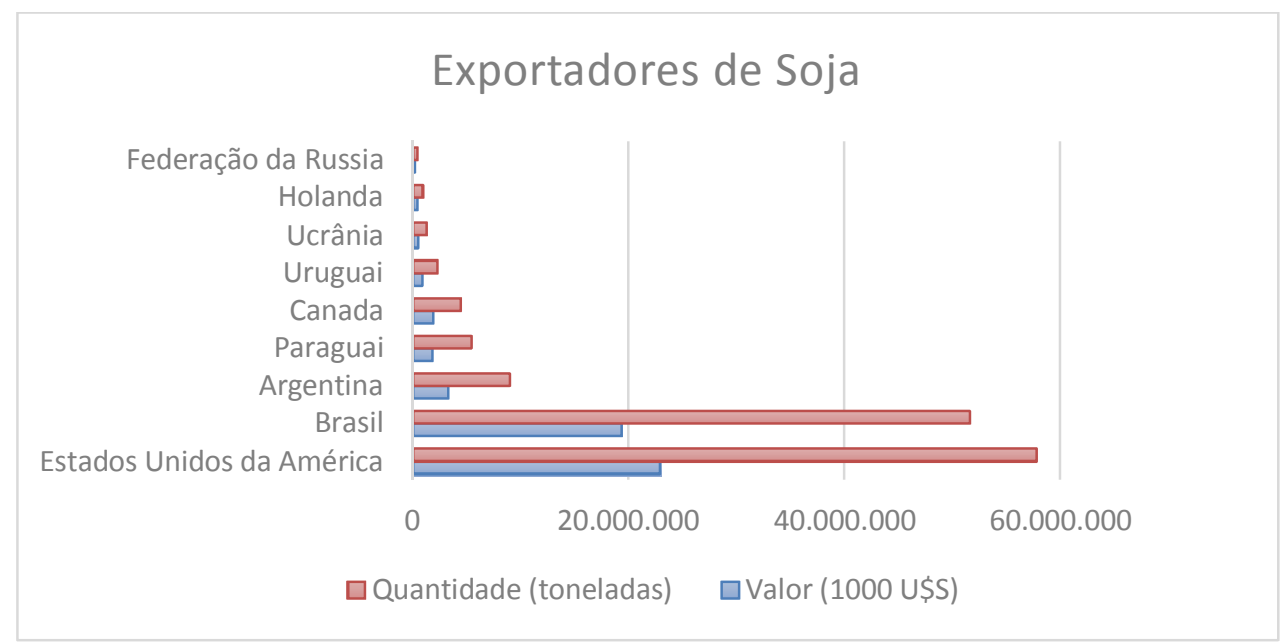

Fonte: Food and Agriculture Organization of the United Nations (2018)

Gráfico 6: Países exportadores de suco de laranja concentrado

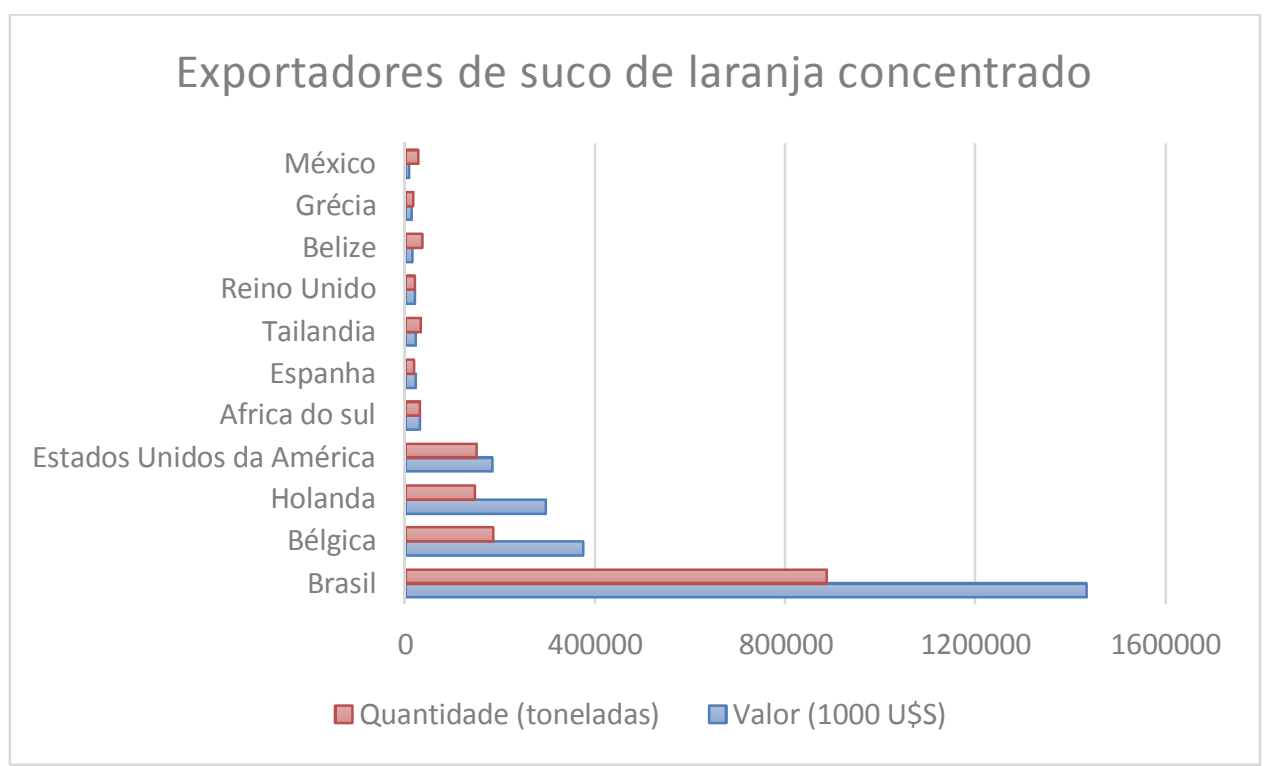

Fonte: Food and Agriculture Organization of the United Nations (2018)

Segundo o Censo Agropecuário de 2017, foram produzidas 90.822 .485 toneladas de milho em 1.628.805 propriedades rurais, 103.739.460 toneladas de soja em 235.766 propriedades rurais e 13.692.308 toneladas de laranja em 55.913 estabelecimentos (Instituto Brasileiro de Geografia e Estatística, 2017).

Apesar de o Brasil figurar como principal player no mercado de commodities, é preciso que a produção busque cada vez mais a eficiência e aumento de produtividade e resultados positivos para que o País continue a figurar como importante produtor e exportador de produtos agrícolas. $\mathrm{O}$ estudo foca no ambiente institucional e seu papel no 
desenvolvimento das organizações, como constatou Douglas North (1991, 1992, 1994, 2005), ao declarar que as instituições são importantes.

O estudo de caso pretende investigar a relação do sistema judiciário e Estado de Direito na tomada de decisões dos agricultores ao escolher contratar ou não determinada atividade, visto que o ambiente institucional pode atuar na diminuição ou aumento da incerteza no ambiente de negócios.

As diferenças nos ambientes institucionais e no sistema judiciário dos Estados Unidos e do Brasil foram abordadas no capítulo anterior, no estudo de caso serão analisadas as informações coletadas por meio das entrevistas dos estudos de caso que ocorreram no Brasil, em diversos estados da Federação.

As categorias de análise do estudo de caso conforme foram apresentadas na metodologia serão: i) perfil e network da empresa, ii) arquitetura organizacional, iii) interferência dos sistemas judiciais e iv) sistema judiciário do Brasil.

\subsubsection{Perfil das propriedades rurais do estudo de caso no Brasil}

No Brasil, as propriedades rurais são classificadas em minifúndios, pequenas propriedades, médias propriedades e grandes propriedades; porém, a classificação depende do número de módulos fiscais que a propriedade ocupa e a área dos módulos fiscais varia de acordo com o município que a propriedade está inserida. $\mathrm{O}$ conceito de módulos fiscais na classificação dos imóveis rurais está presente na Lei no 8.629/1993 (Art. 4, II e III), na definição de pequena propriedade (imóvel de área compreendida entre um e quatro módulos fiscais) e média propriedade (imóvel rural de área superior a quatro e até 15 módulos fiscais), ficando entendido que o minifúndio é o imóvel rural com área inferior a um módulo fiscal, e a grande propriedade aquela de área superior a 15 módulos fiscais. O valor do módulo fiscal no Brasil varia de cinco a 110 hectares, a Tabela 14, apresentada a seguir, utiliza o tamanho médio na federação das propriedades. (Instituto Nacional de Colonização e Reforma Agrária, 2018). 
Tabela 14: Número de estabelecimentos agropecuários e Área dos estabelecimentos

\begin{tabular}{|l|r|r|r|}
\hline Classes de módulo fiscal & $\begin{array}{c}\text { Número de } \\
\text { Estabelecimentos }\end{array}$ & $\begin{array}{c}\text { Área total ocupada } \\
\text { (hectares) }\end{array}$ & $\begin{array}{c}\text { Tamanho médio das } \\
\text { propriedades }\end{array}$ \\
\hline De 0 a menos de 1 (pequeno) & $3.813 .196,00$ & $40.709 .306,00$ & 10,68 \\
\hline De 1 a menos de 2 (pequeno) & $504.458,00$ & $26.113 .232,00$ & 51,76 \\
\hline De 2 a menos de 4 (pequeno) & $272.794,00$ & $27.418 .316,00$ & 100,51 \\
\hline De 4 a menos de 10 (médio) & $190.569,00$ & $44.760 .700,00$ & 234,88 \\
\hline De 10 a menos de 15 (médio) & $47.856,00$ & $22.265 .385,00$ & 465,26 \\
\hline De 15 a menos de 20 (grande) & $25.728,00$ & $17.068 .695,00$ & 663,43 \\
\hline De 20 a menos de 50 (grande) & $46.932,00$ & $55.094 .887,00$ & $1.173,93$ \\
\hline De 50 a 100 (grande) & $12.372,00$ & $36.305 .028,00$ & $2.934,45$ \\
\hline Mais de 100 (grande) & $6.712,00$ & $63.944 .488,00$ & $9.526,89$ \\
\hline
\end{tabular}

Fonte: elaborado pela autora, com base no Instituto Brasileiro de Geografia e Estatística (2017)

As entrevistas foram realizadas em dez propriedades rurais no Brasil, as quais estão presentes em diversos estados do Brasil. A Figura 13 mostra as localidades.

Figura 13: Mapa das propriedades do Estudo de Caso no Brasil

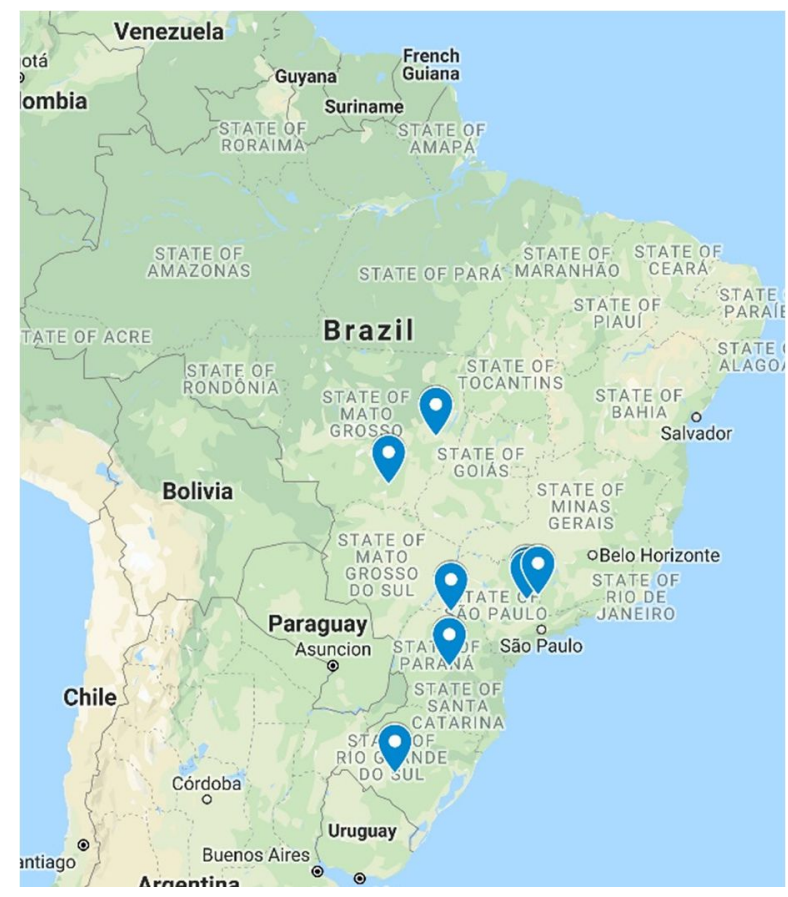

Fonte: Google maps, adaptado pela autora (2018, s/p.)

Seguindo a classificação do INCRA, a maioria das propriedades entrevistadas (seis propriedades) foi de grande porte, com mais de 15 módulos fiscais e área média de 1.300 hectares, duas propriedades médias com área média de 420 hectares e uma pequena propriedade, com menos de quatro módulos fiscais com 50 hectares. Também foi entrevistada uma consultoria que representa algumas grandes propriedades no Mato Grosso, que é 
responsável pela gestão técnica e administrativa de, aproximadamente, cinco mil hectares de grãos e 40 mil hectares de pecuária. Apesar de o foco ser em propriedades de lavoura de laranja e grãos, no Brasil as propriedades rurais são diversificadas; então, por vezes, a propriedade cultivava as duas culturas e, muitas vezes, associava outras culturas à principal, como cana-de-açúcar, café e outras.

Todos os produtores entrevistados se dedicavam a mais de uma atividade agrícola ou pecuária, a média de culturas que eles estavam envolvidos era três. Na produção de grãos todos se dedicavam à safra principal e à safrinha, além dos produtores que se dedicavam à atividade de produção de commodities, mas também atuam em outros elos da cadeia do agronegócio, sendo na parte de insumos, como a produção de mudas ou no processamento do produto, em produtos laticínios e, ainda, na comercialização e armazenamento de grãos.

Nas propriedades que se dedicavam somente à produção de commodities, a média do número de colaboradores era de dez pessoas, enquanto os produtores que estavam envolvidos em outros elos da cadeia apresentam, em média, 14 colaboradores, variando entre um número total de quatro até 25 colaboradores.

O Quadro 12, apresentado a seguir, traz o resumo das informações de área total, área de grãos, culturas cutivadas e número de colaboradores de cada caso. 
Quadro 12 -Perfil das propriedades rurais do Brasil

\begin{tabular}{|c|c|c|c|c|}
\hline Produtor & $\begin{array}{c}\text { Área total } \\
\text { propriedade } \\
\text { (hectares) }\end{array}$ & $\begin{array}{l}\text { Área produção } \\
\text { grãos (ha) }\end{array}$ & Culturas & $\begin{array}{l}\text { Número colaboradores } \\
\text { (família incluída) }\end{array}$ \\
\hline$B R 1$ & 360 & 223 & $\begin{array}{c}\text { Soja } \\
\text { Milho } \\
\text { Laranja e Painço }\end{array}$ & 6 \\
\hline$B R 2$ & 2470 & 600 & $\begin{array}{c}\text { Soja } \\
\text { Milho } \\
\text { Laranja } \\
\text { Cana-de-açucar } \\
\text { Feijão e Batata } \\
\end{array}$ & 25 \\
\hline$B R 3$ & 640 & 640 & $\begin{array}{l}\text { Soja safra } \\
\text { Milho safrinha }\end{array}$ & 4 \\
\hline$B R 4$ & 50 & - & $\begin{array}{l}\text { Laranja } \\
\text { Mudas }\end{array}$ & 12 \\
\hline BR5 & 600 & 600 & $\begin{array}{c}\text { Soja } \\
\text { Milho } \\
\text { Cana-de-açucar e } \\
\text { café } \\
\end{array}$ & 20 \\
\hline BR6 & 1450 & 200 & $\begin{array}{c}\text { Soja } \\
\text { Milho } \\
\text { Cana-de-açucar e } \\
\text { pecuária } \\
\end{array}$ & 11 \\
\hline$B R 7$ & 200 & 200 & $\begin{array}{c}\text { Soja } \\
\text { Milho } \\
\text { Pastagem } \\
\end{array}$ & 8 \\
\hline$B R 8$ & 5000 & 5000 & $\begin{array}{c}\text { Soja } \\
\text { Milho } \\
\text { Pastagem }\end{array}$ & não mencionado \\
\hline$B R 9$ & 2200 & 2000 & $\begin{array}{c}\text { Soja } \\
\text { Pastagem }\end{array}$ & não mencionado \\
\hline
\end{tabular}

Fonte: elaborado pela autora (2019)

A estrutura de equipamentos das fazendas é bem variada, dado que os produtores também se envolvem em mais de uma atividade produtiva. As propriedades costumam possuir todo o maquinário para realizar as atividades, tratores, plantadeiras, pulverizadores de defensivos químicos, combinadas para colher os grãos, sendo a prestação de serviços utilizada em ocasiões que os produtores necessitam de maior capacidade para complementar as atividades executadas dentro da firma, quando a atividade é sazonal e secundária na fazenda ou quando necessitam de algum serviço mais sofisticado e especializado como a pulverização aérea de defensivos. No Brasil, não foi constatada situação em que os produtores rurais não possuem nenhum equipamento e terceirizam todas as atividades. 
O histórico dos produtores entrevistados tem sempre nas gerações anteriores da família o motivo de estarem envolvidos na agropecuária, sendo a maioria fruto de processos sucessórios ou de aquisição de terras, após terem trabalhado com as famílias. Alguns dos breves relatos são apresentados a seguir:

“A propriedade está na família desde o avô, que tem o meu nome, ou seja, a fazenda e a agricultura estão na família há três gerações. Meu pai tomava conta da fazenda, mas em 1979 saiu e eu assumi os negócios. O pai, apesar de estar fora da operação no dia a dia, ainda ajuda na tomada de decisão, além de mim meu cunhado também ajuda na atividade. " (Produtor BR1).

“A família possui propriedades rurais desde a geração do avô, que iniciou na pecuária com gado de leite e atualmente expandiu para outras culturas como laranja, grãos, feijão, batata, cana-de-açúcar, beterraba. " (Produtor BR2).

“A família está presente no agronegócio há mais de 20 anos, porém, por um breve período deixaram de produzir, mas há oito anos retomaram comigo, o filho, e hoje sou responsável pela produção." (Produtor BR3).

“O pai sempre foi agricultor, cultivava algodão e cereais na região. É de uma família de oito irmãos. Quando me casei, meu sogro plantava laranjas e durante um café da tarde embaixo de um pé de laranja, me incentivou a começar a cultivar também; além de produzir a commodity, também resolvi trabalhar na produção de mudas, comecei em uma época em que a cultura estava se expandindo. "(Produtor BR4).

"A família tinha fazendas, eu me foremi agrônomo em 1978 e fui vender insumos. Em 1981, iniciei minhas atividades na agricultura em Minas Gerais, cidade de Bambuí. Em 1987, vi uma oportunidade de negócios na comercialização de grãos e iniciei a empresa. Atualmente, trabalho tanto na comercialização dos grãos como na produção de grãos, canade-açúcar e café.” (Produtor BR5).

“Eu e minhas irmãs herdamos a fazenda do pai em 2002, quando ele faleceu. Eu, no entanto, já o auxiliava na atividade produtiva desde que me formei em Engenharia Agronômica, em 1991. Estamos em diversas atividades, grãos, cana-de-açúcar e integração pecuária-floresta, em que produzem bovinos e eucaliptos.” (Produtora BR6).

“A atividade agropecuária está na família há três gerações, minha família é pioneira na região no sistema de plantio direto na palha, há 35 anos utilizamos a tecnologia, também começamos a importar sementes de soja transgênicas na lavoura de grãos na região." (Produtor BR9). 


\subsubsection{Arquitetura organizacional}

\subsubsection{Estruturas de governança}

No Brasil, as propriedades rurais são diversificadas quanto a suas atividades, o que torna a estrutura das fazendas mais complexas. Diferentemente de países que se organizam a produção agropecuária por regiões e cinturões especializados, no Brasil, apesar de se respeitar a aptidão agrícola, o clima é favorável e permite aos produtores rurais diversificar.

Grande parte dos agricultores do estudo de caso (oito dos nove produtores entrevistados) contrata de terceiros pelo menos uma atividade dentro de sua propriedade. Quando se faz um corte na amostra das propriedades do estudo e focaliza nas propriedades diversificadas com mais de uma cultura, a adoção da terceirização é ainda maior e todos os produtores diversificados (oito) contratam algum serviço, revelando que produtores que diversificam não têm habilidade de se especializar em todas as atividades e não possuem estrutura suficiente para atenderem a todas as suas atividades.

Nesse contexto de terceirização no Brasil, observa-se uma distinção quanto à decisão pela terceirização quando o produtor (tomador de decisão) está focado somente em uma cultura (atividade). A decisão no País também se alicerça na decisão de focar sua infraestrutura na cultura (atividade) principal, não é pautada apenas pelos maiores custos de transação. Em conformidade com a constatação, ocorre que a atividade terceirizada em três das propriedades que contratam serviços acontece nas culturas complementares, não na cultura principal da propriedade. Outras duas propriedades que terceirizam, e o fazem na cultura principal, contratam para complementar sua capacidade produtiva, quando estão expandindo suas áreas e os equipamentos e mão de obra disponíveis não são suficientes. As outras três propriedades que contratam atividades o fazem na cultura da laranja, que demanda alta necessidade de trabalho de mão de obra sazonal, o caso da colheita dos frutos.

O Quadro 13, a seguir, mostra como as propriedades do estudo de caso são organizadas em relação às estruturas de governança das atividades produtivas. 
Quadro 13 - Terceirização nas propriedades rurais do Brasil

\begin{tabular}{|c|c|c|c|c|}
\hline Produtor & Terceiriza & Atividades terceirizadas & Presta serviços & $\begin{array}{c}\text { Área produção } \\
\text { grãos (ha) }\end{array}$ \\
\hline$B R 1$ & $\operatorname{sim}$ & Colheita de laranja & $\operatorname{sim}$ & 223 \\
\hline$B R 2$ & sim & $\begin{array}{l}\text { Colheita de laranja e } \\
\text { pulverização aérea de } \\
\text { defensivos em todas as } \\
\text { culturas. }\end{array}$ & $\operatorname{sim}$ & 600 \\
\hline$B R 3$ & Não & & não & 640 \\
\hline$B R 4$ & $\operatorname{sim}$ & $\begin{array}{c}\text { Colheita de laranja e } \\
\text { especialistas na enxertia }\end{array}$ & não & - \\
\hline$B R 5$ & $\operatorname{sim}$ & Plantio parcial soja (15\%) & não & 600 \\
\hline$B R 6$ & $\operatorname{sim}$ & $\begin{array}{c}\text { Corte, carregamento e } \\
\text { transporte da cana-de- } \\
\text { açucar }\end{array}$ & não & 200 \\
\hline$B R 7$ & $\operatorname{sim}$ & Silagem na pastagem & $\operatorname{sim}$ & 200 \\
\hline$B R 8$ & $\operatorname{sim}$ & $\begin{array}{c}\text { Colheita parcial de grãos } \\
(50 \%) \text { para silagem e } \\
\text { pulverização aérea de } \\
\text { defensivos }\end{array}$ & não & 5000 \\
\hline$B R 9$ & $\operatorname{sim}$ & $\begin{array}{c}\text { Colheita parcial de grãos } \\
(15 \%)\end{array}$ & não & 2000 \\
\hline
\end{tabular}

Fonte: elaborado pela autora (2019)

Logo, como no Brasil o estudo de caso ocorreu em uma maior diversidade de culturas, é preciso evidenciar as particularidades nas estruturas, de acordo com as culturas abordadas.

Recortando o estudo de caso para as culturas de grãos, tanto em propriedades que têm na cultura sua principal área plantada quanto nas que utilizam como cultura subsidiária, 5 dos 9 casos nas propriedades de grãos são integradas verticalmente para atividades na soja e milho e desenvolvem todas as suas atividades internamente na propriedade, desde o plantio, aplicação de fertilizantes e adubação, pulverização de defensivos, até a colheita. No entanto, o transporte e o armazenamento, atividades auxiliares por vezes é terceirizado, mas o presente estudo de caso limitou-se a atividades desempenhadas dentro da porteira. Os quatro dos nove 
casos que terceirizam atividades, no entanto, apresentam particularidades que merecem ser discutidas individualmente.

O produtor do caso BR2 tem todos os equipamentos e realiza $90 \%$ das operações nos grãos internamente, porém contrata serviço de pulverização aérea de defensivos, por causa da baixa frequência que utiliza e por ser um serviço especializado, que envolveria um investimento alto para baixa taxa de utilização.

Outros 2 produtores de grãos brasileiros do caso BR5 e BR9 terceirizam atividades, todavia, eles possuem equipamentos e contam com pessoas capacitadas para realizá-las; porém, não em quantidade suficiente. O produtor BR5 relatou que contratou pela primeira vez na safra 2018/2019 um vizinho para realizar o plantio de soja de 100 hectares dos 600 hectares totais de sua operação. O BR9 terceirizou $15 \%$ da sua operação de colheita nesta safra, pois está expandindo sua operação para 2.200 hectares. Ambos experimentaram a terceirização nessa última safra 2018/2019, e contrataram o serviço de vizinhos. Foi exposto que ainda há escassez de empresas profissionalizadas.

O BR8 é o caso do produtor/pecuarista que é consultor e administrador de diversas propriedades de grãos e pecuária, e foi incluído porque ele é o tomador de decisões nestas propriedades (aproximadamente cinco mil hectares de grãos e 15 mil hectares de pecuária). Ele relatou que em $50 \%$ da área de grãos foi utilizada colheita terceirizada.

Apesar de o estudo não ter capturado casos de terceirização total de atividades, foi observado por um agricultor que algumas grandes empresas estão optando pela terceirização integral de algumas atividades, como "grandes empresas sementeiras que possuem em torno de 30 mil hectares na região têm utilizado colheita totalmente terceirizada para não imobilizar o capital em equipamentos onerosos, a grande escala do cliente garante que o prestador de serviços esteja empenhado e não deixe de cumprir o combinado", ressaltou produtor rural de BR3.

Os agricultores de grãos possuem todos os equipamentos necessários, alguns relataram que não têm equipamentos modernos, mas que este equipamento ainda os permite executar as atividades sem perdas. Existem os que preferem, mesmo não tendo área suficiente, adquirir bons equipamentos e prestar serviço para os vizinhos.

O agricultor de BR1, em sua propriedade rural de 360 hectares, sendo 220 dedicados aos grãos, relatou que optou por possuir uma colheitadeira nova de grãos, recém-adquirida, e duas plantadeiras, para utilizar seu fácil acesso a financiamento no banco, e ele, então, presta serviços para os vizinhos. Nessa última safra, plantou 25 hectares para vizinhos e colheu além da sua lavoura mais 380 hectares para conhecidos, totalizando uma colheita de 600 hectares 
no verão. Ele optou por esse arranjo para ajudar nos custos de produção e otimizar a utilização do equipamento que ficaria ocioso. Existem mais produtores que se organizam da mesma forma e preferem possuir toda a estrutura em sua propriedade, mesmo que tenham capacidade ociosa e, com ela, prestar serviços aos vizinhos. Três produtores de grãos relataram adotar arranjos semelhantes e atuar como produtores e prestadores de serviços.

Outra atividade terceirizada relatada em grãos é a pulverização aérea, os produtores de grande porte, BR2 e BR8, relataram contratar empresas aéreas especializados na proteção de culturas em suas propriedades.

Passando a analisar a cultura da laranja, com pomares perenes, todos os 3 produtores da fruta do estudo, BR1, BR2 e BR4 terceirizam uma atividade, a colheita de laranja. No Brasil, apesar de esforços para desenvolvimento e adoção de tecnologia na colheita, na maioria dos pomares ainda se utiliza colheita manual dos frutos. Os três métodos de colheita disponíveis, segundo Mascarin (2006), são: manual, semimecanizado e mecanizado. O método manual é aquele encontrado amplamente no estado de São Paulo e em pomares destinados ao comércio in natura. O método semimecanizado consiste na derriça mecanizada e recolhimento manual. Já na colheita mecanizada, tanto a derriça quanto o recolhimento são feitos por máquinas automotrizes, com perdas observadas de até 7\% por frutos deixados no chão e por esmagamento. Ainda que o mais utilizado, o método manual é desatualizado e tem aumentado os entraves à sua viabilidade, por causa da crescente escassez de mão de obra no campo e aumento dos encargos trabalhistas, o que torna a colheita responsável por $30 \%$ a $50 \%$ do custo total de produção de laranja. Em vista disso, segundo Osorio, Lima, Sant'anna e Castro (2017), a falta de maquinários para a colheita da laranja afeta os custos. O estudo de caso adiciona a esse achado que, além de afetar os custos, a falta de máquinários afeta a estrutura de governança das propriedades de laranja, ficando o produtor de laranja dependente sazonalmente de grande quantidade de trabalhadores para realizar a colheita.

Os produtores, ao contratarem a mão de obra para colheita, optam por contratar terceiros, sendo adotados os contratos por 'empreita', ou realizados por cooperativas e/ou consórcios. A opção pela terceirização se dá porque a atividade exige muitos trabalhadores que serão necessários somente por um período de tempo e que, se integrados verticalmente, teriam que ser realocados em outra atividade após o término da colheita; entretanto não existe trabalho suficiente para realocar todos os trabalhadores. Os produtores de laranja que terceirizam a colheita, no entanto, conhecem os riscos que a prática traz à operação, riscos que serão discutidos na seção 5.2.3.4 e, apesar dos riscos, eles são categóricos ao afirmar que não existe a opção de integrar tal atividade. Para diminuir os riscos, os produtores contratam 
baseados na idoneidade e boa reputação do terceiro, na seção 5.2.3.3, será relatada a história de um consórcio que atua na prestação deste serviço para produtores no interior de São Paulo.

Um dos produtores de laranja, BR4, além de produzir os frutos é produtor de mudas, e além de contratar a colheita, ele contrata adicionalmente profissionais especialistas na enxertia duas vezes ao ano, ele relatou que, apesar de ter funcionários suficientes em suas estufas, seus colaboradores não são especializados nem tão eficientes quanto os profissionais contratados para realizar esse serviço.

Como, além das culturas principais do estudo, os produtores também possuíam outras culturas, a seguir serão descritos que outras atividades são terceirizadas nas propriedades do estudo de caso do Brasil.

Na propriedade BR6 diversificada de grãos, cana-de-açúcar, integração pecuáriafloresta, a agricultora relata que, apesar da cultura de grãos que ocupa 200 hectares ser integrada verticalmente, ela realiza contratos de terceirização em outras culturas. Nos 500 hectares de cana-de-açúcar, a usina é responsável pelo plantio, além de ser responsável pelo CCT (corte, carregamento e transporte). Ela opta por subcontratar o serviço da usina por não possuir equipamento necessário nem pessoas suficientes, quando o assunto é o plantio da cana; o acordo conta com contratos para assegurar que as condições sejam cumpridas e o pagamento pelo serviço é descontado do pagamento que a usina faz a ela pelo fornecimento da cana. Contratar da usina oferece facilidade ao realizar o pagamento em produto e não ter que imobilizar capital ou dispor de recursos adiantados para pagar o serviço. Outra atividade que ela terceiriza é o corte do eucalipto, uma atividade que tem uma frequência baixa e exige máquinas pesadas e mão de obra qualificada.

Outro caso é de outra propriedade BR7 diversificada de grãos e pecuária de leite; a parte da pecuária e leiteria é toda integrada verticalmente, bem como a produção de grãos, porém, três vezes ao ano o produtor contrata serviço de silagem para utilizar parte dos grãos na alimentação dos bovinos de leite. Como é necessário possuir máquina especializada e somente parte da produção é destinada a esse fim, o agricultor acredita que não vale a pena integrar a atividade, uma vez que existe terceiros especializados e competentes na região.

Outras atividades especializadas são contratadas, como no caso de inseminação artificial na pecuária, silagem, consultoria em novas culturas da propriedade, bem como algumas atividades esporádicas, como construção de cercas e currais.

Poucas atividades foram consideradas no leque de atividades que os produtores não terceirizariam, o plantio de grãos provavelmente foi o menos considerado para a contratação. Um dos produtores considerou o plantio como a mais essencial atividade na produção de 
milho e soja: 'se errar no plantio, errou tudo', pelo fato de a atividade interferir diretamente na produtividade final. Outra atividade que foi citada por um deles foi a pulverização, por causa da especificidade temporal da aplicação, 'se não realizada no momento ideal a produtividade será reduzida'. Entretanto, essa atividade teve opiniões diversas, assim como alguns não consideram a terceirização outros consideram contratar soluções para a proteção química da lavoura no futuro.

A colheita, no entanto, é uma das atividades que os produtores consideram a contratação no futuro como forma de ter acesso a tecnologias mais modernas, correndo, porém, o risco da janela curta entre colheita e plantio, como enfatizaram.

Muitos produtores alegam que, no Brasil, a terceirização ainda é muito informal, se houvesse, segundo eles, empresas especializadas, sérias e idôneas, a prática seria mais adotada como forma de especialização das atividades. Um produtor do sul do País mencionou que na Argentina e no Uruguai a prática de prestação de serviços é mais especializada que no território nacional, organizada por meio de uma associação, os fornecedores de serviço se chamam de contratistas rurales, e que no Brasil a atividade de terceirização está somente começando a engatinhar e sair da informalidade, depois da nova lei de 2017.

\subsubsection{Prestadores de serviços}

No Brasil os prestadores de serviços agricultores contabilizam a maior parcela de serviços prestados na agricultura; nos grãos, 3 dos 9 produtores do estudo de caso (BR1, BR2 e BR7), além de serem agricultores, prestam serviços para os vizinhos e conhecidos, com a capacidade ociosa de seus equipamentos. A propriedade dos equipamentos muitas vezes é justificada financeiramente para esses agricultores somente por, além de realizar as atividades de suas propriedades, também prestam serviços a terceiros, os equipamentos servem para complementar a renda da produção e venda dos produtos agrícolas.

Todos os agricultores que prestam serviços nos grãos o fazem por meio de acordos relacionais, não formalizam contratos e não veem necessidade de prever contingências, já que a reputação entre iguais é garantia suficiente para dispensar a formalização do acordo.

Na produção de laranja, os prestadores de serviços são especializados (focados) e não são os produtores; normalmente um terceiro organiza as 'turmas' e negocia a empreita com os produtores rurais. A atividade frequentemente terceirizada na laranja é a colheita, por causa da necessidade de alto volume de mão de obra sazonal. Os acordos realizados entre os produtores e prestadores de serviços são impessoais e formalizados mediante contratos na tentativa de 
evitar problemas que os produtores possam vir a enfrentar, uma vez que são recorrentes intervenções judiciais e problemas trabalhistas que envolvam terceirização de serviços no setor da laranja.

No estudo de caso, um arranjo entre produtores de laranja e prestadores de serviços mostrou-se particularmente interessante, pois as duas partes se associaram em um consórcio, administrado pelo terceiro, o BRService1. Esse arranjo emergiu quando o pai da atual administradora do consórcio percebeu uma oportunidade de prestar serviços para os produtores e pomares de laranja e abriu uma empresa de serviços, a P.sev (que posteriormente se tornou S. H. Colheitas Rurais, ou BRService1 como será referida) até que, em 2005, a terceirização foi totalmente pró́bida. Então a atual administradora, também advogada, organizou na época a empresa como a figura consórcio, em que é organizado um condomínio, que tem a antiga empresa, BRService1, como administradora deste condomínio e os consorciados são os produtores rurais que, por meio de um contrato de adesão ao consórcio, se tornam responsáveis solidariamente. $\mathrm{O}$ esforço se tornou uma ação coletiva da empresa e dos produtores rurais para que os custos de colheita não se tornassem proibitivos se integrados verticalmente ou para que a alternativa de subcontratar fosse a ilegalidade dos "turmeiros".

O consórcio nasceu da necessidade de formalizar a relação entre as partes, em um contexto que terceirizar a atividade fim era proibido. O consórcio e sua administradora BRService1, no entanto, se esforça e cumpre todas as legislações trabalhistas e normas. A administradora contrata todos os colhedores e registra a carteira trabalhista. Os consorciados são cobrados por caixa colhida e, nesse custo, são incluídos assistência jurídica, equipamentos de proteção individuais, encargos trabalhistas, frete de onibus para colaboradores e o salário do colhedor. Ao comparar o preço da colheita do consórcio com seus concorrentes ela ressalta que cobra um preço mais caro, pois a maioria dos outros 'turmeiros' são ilegais e não cumprem a legislação trabalhista. Ela trabalha na conscientização de antigos ‘turmeiros' e dos colhedores que trabalhar legalizado tem inúmeros benefícios. Além de garantir o direito dos trabalhadores, o consórcio realiza a inclusão de ex-detentos na sociedade, ofertando um trabalho 'com carteira assinada' para esses que, muitas vezes, não conseguiriam outra oportunidade.

Apesar de muitas vezes ter sido autuada pelo Ministério do Trabalho por causa da NR 31, que versa principalmente sobre o uso de equipamento de proteção individual (EPI), a proprietária da administradora ressalta que sempre disponibilizou o equipamento, e que as ordens de usá-lo eram ignoradas pelos trabalhadores que não usavam; no entanto, após dez 
anos, conseguiu conscientizar o colhedor a colocar em prática o EPI, com penalidade para o funcionário que não usar.

Os consorciados, alguns dos quais participantes do estudo de caso (BR1 e BR2) garantiram que a administração, direção, respeito pelo trabalhador e reputação da administradora do consórcio foi o incentivo a eles participarem desse arranjo. Ademais, em todos os anos que os produtores estiveram no arranjo enfrentaram menor número de problemas judiciais do que outros produtores que se arriscavam com 'turmeiros', com preços mais baixos.

\subsubsection{Valor Criado}

O valor criado nos contratos de terceirização vem da percepção que os participantes do mercado têm a respeito das vantagens dos acordos e dos possíveis prejuízos que as estruturas de governança escolhidas podem causar às empresas.

Muitas vantagens foram mencionadas pelos produtores rurais na contratação de serviços terceirizados na agricultura brasileira. A mais citada por eles se refere aos custos de manter um parque de máquinas e o valor imobilizado em equipamentos. $\mathrm{Na}$ linha de vantagens de custos, alguns citaram também a economia de recursos e tempo na manutenção de equipamentos.

O agricultor, pecuarista, administrador e consultor de propriedades do BR8 citou que 'por causa dos juros altos no Brasil não compensa comprar máquinas e implementos financiados, além do acesso a financiamento público a juros baixos ser muito restrito, e o financiamento em bancos particulares ter juros altos o que pode tornar o custo final muito alto. Para compensar comprar uma colheitadeira nova é preciso ter uma área de aproximadamente mil hectares de soja atualmente', opinou o consultor.

A imobilização do capital em equipamentos tão caros também foi um fator amplamente citado como vantagem. Em propriedades pequenas não faz sentido possuir equipamentos caros, uma vez que a capacidade de alguns equipamentos excederia a necessidade. Em médias e grandes propriedades, o valor imobilizado poderia ser utilizado em alguma atividade alternativa, um dos produtores estima que tem aproximadamente quatro milhões de reais imobilizados e que poderia usar o dinheiro para expandir sua área, caso houvesse prestadores de serviços em sua região que fossem especializados e garantissem o bom desempenho das atividades. 
Além dos argumentos citados sobre custos favorecendo a terceirização, a contratação de mão de obra rural especializada no Brasil está se tornando cada vez mais cara e escassa. Ademais da escassez de trabalhadores no campo, algumas das atividades exigem maior treinamento e conhecimento dos funcionários, tais como atividades que exijam conduzir máquinas com tecnologia de ponta, além da especialização, que torna o funcionário mais caro, essas atividades são sazonais na propriedade, não justificando a integração.

O acesso a máquinas novas e tecnologias avançadas também é uma conveniência citada, uma vez que quando adquirem máquinas novas, os produtores tendem a ficar com elas por alguns anos, uma vez que a maioria dos produtores não pode arcar com o custo de comprar, frequentemente, máquinas novas e mais modernas.

Em atividades com alta intensidade de trabalho e mão de obra temporária, como é o caso da colheita da laranja os produtores destacaram a vantagem de delegar a outrem a preocupação com as complexas leis trabalhistas e encargos do país, uma vez que quando contratam o serviço esses custos estão incluídos, além do pagamento ser atrelado a produtividade do serviço, repassando a preocupação de calcular todos os custos para o prestador de serviços. Além de delegarem a direção e contratação de grande número de funcionários, atividades que teriam que ser realizadas caso a atividade fosse integrada verticalmente. Um deles ressaltou que 'todos os produtores de laranja terceirizam a colheita, nós não conseguiríamos integrar a atividade na propriedade a não ser que fosse uma grande propriedade'.

Todavia, no que diz respeito à mão de obra, foi enfatizado que é preciso contratar serviço de fornecedores confiáveis, uma vez que estes precisam assegurar os direitos trabalhistas dos funcionários e o pagamento e o recolhimento de impostos, caso contrário, esse serviço pode vir a trazer problemas judiciais aos contratantes, mesmo que esses não tenham sido negligentes, tenham cumprido os contratos e apresentem nota fiscal do pagamento do serviço.

Entre as possíveis desvantagens na terceirização de serviço percebida no Brasil pelos produtores rurais estava a preocupação com o desempenho e eficiência que o terceiro executaria a atividade, uma vez que, se não bem executado, o impacto negativo não seria sentido pelo prestador e somente pelo contratante, um problema clássico de agência.

A especificidade temporal no Brasil é uma questão que foi adicionada por alguns, uma vez que no cultivo dos grãos a janela entre as atividades de colheita e o plantio no País é curta, por causa das duas safras no ano, safra e safrinha. 
Adicionalmente à especificidade temporal, foi adicionada a pouca disponibilidade de prestadores de serviços profissionais, com acordos formais que garantam o desempenho do serviço bem como a data que ele iniciará visto que, quando se contratam produtores com a capacidade ociosa, é preciso esperar que eles realizem a atividade, primeiramente, para si próprios, ou ainda, como adicionou um produtor rural, "existe o risco de não cumprirem o acordo, além de poderem mudar os termos combinados a qualquer momento já que não existe penalidade, logo se existe alguém disposto a pagar um preço maior pela urgência, seu serviço pode ser atrasado e você pode ficar na mão. E algumas operações não é possível admitir erros ou atrasos." (Produtor BR3).

Os custos figuram tanto como um benefício como uma desvantagem, os altos impostos no País, especialmente incidentes sobre serviços, foram citados por um profissional que atua tanto na produção como na prestação de serviços: 'o problema de prestar serviços é o imposto alto que está embutido nele, a porcentagem pode atingir 19\% do valor do serviço sendo que, para o produtor rural, a taxa de imposto aplicada é menor. Para que no Brasil a prestação de serviços se profissionalizasse e se tornasse viável, seria preciso que houvesse incentivos, como menor incidência de impostos.' (Produtor BR8).

A falta de contratos e profissionalismo na prestação de serviços faz com que os produtores não se sintam confiantes a contratar todas as atividades, eles veem o contrato como uma ferramenta mitigadora de riscos, tanto relativos ao cumprimento do acordo quanto à responsabilidade que os prestadores assumem ao contratar um serviço. Pela nova lei de terceirização existe a corresponsabilidade do tomador do serviço; no entanto, a maioria dos produtores não tem consciência plena das responsabilidades das partes, mas eles presumem que existam riscos, uma vez que quase todos conhecem histórias sobre problemas trabalhistas, se não com eles próprios, com conhecidos. Os riscos que alguns assumem são relacionados a problemas trabalhistas, caso venha a acontecer algum acidente de trabalho, ou ao não cumprimento de leis pelos terceiros, por exemplo. Um produtor rural observou que 'caso ocorra algum problema sempre 'sobra' mais para o proprietário da terra' (Produtor BR2).

Raros são os casos que realmente têm conhecimento pleno da situação da corresponsabilidade na terceirização e até da proibição anterior, pela Súmula 331 do Tribunal Superior do Trabalho. Uma produtora rural notou que 'apesar de ser corresponsável, acredita que pelo menos agora com a lei a responsabilidade é limitada' (Produtora BR6).

No Brasil, o balanço do valor criado para os produtores rurais, um índice criado por meio da soma de benefícios subtraído dos prejuízos relatados pelos produtores, apresenta uma média de 0,88 , verificando que para eles subcontratar um serviço gera valor na atividade 
produtiva. Os índices de cada um dos casos são apresentados no Quadro 14. O quadro mostra que, independentemente da cultura, se o produtor rural enxerga valor na desintegração de atividades através de contratos, ele terceiriza alguma atividade em sua operação.

Quadro 14: Percepção brasileira de valor criado na terceirização de atividades

\begin{tabular}{|c|c|c|}
\hline Produtor & Terceiriza & Valor Criado \\
\hline$B R 1$ & $\operatorname{sim}$ & 0 \\
\hline$B R 2$ & $\operatorname{sim}$ & 0 \\
\hline$B R 3$ & Não & -1 \\
\hline$B R 4$ & $\operatorname{sim}$ & 0 \\
\hline$B R 5$ & $\operatorname{sim}$ & 3 \\
\hline$B R 6$ & $\operatorname{sim}$ & 2 \\
\hline$B R 7$ & $\operatorname{sim}$ & 1 \\
\hline$B R 8$ & $\operatorname{sim}$ & 1 \\
\hline$B R 9$ & $\operatorname{sim}$ & 2 \\
\hline
\end{tabular}

Fonte: elaborado pela autora (2019)

Muito desse resultado é movido pelo entusiasmo dos produtores com a nova lei e pela percepção de que ao terceirizar imobilizarão menor soma de recursos em estrutura e que ao transferir a atividade terão menos preocupações com algumas burocracias e leis relacionadas a elas, muitas vezes erroneamente acreditam que estão delegando também a responsabilidade quando contratam o serviço.

\subsubsection{Incerteza e risco}

Uma das vantagens de terceirizar uma atividade é o gestor não ter que se preocupar com todos os pormenores de sua gestão, nem com a própria verificação detalhada da tarefa, podendo dedicar o tempo e o esforço para focar em outras atividades. Ao abrir mão de 
executar a atividade e confiar a alguém a tarefa, o tomador de decisões espera menor direito de decisão e controle de como a atividade será desempenhada, mas também enseja menor responsabilidade judicial sobre seus resultados, positivos ou negativos.

A terceirização e a contratação de serviços em atividades-fim no Brasil eram proibidas até o advento da Lei $\mathrm{n}^{\mathrm{o}} 13.429$ (Brasil, 2017). A lei permitiu que as atividades fossem terceirizadas, porém adicionou cláusulas que tornam o contratante corresponsável pelos riscos, sendo eles ambientais, trabalhistas ou civis.

Os agentes tomam decisões baseado em seu conhecimento, experiência e sua percepção do ambiente; as leis são importantes, porém, a maioria dos agentes não as conhece amplamente, logo a percepção dessas leis, sua alocação de riscos e responsabilidades é quase mais importante que a própria lei, uma vez que é a partir dessa compreensão que as decisões são tomadas.

Além do risco da responsabilidade, a incerteza de como disputas sobre os serviços contratados serão resolvidas afetam a tomada de decisão. Se a percepção das partes de que a alocação de riscos pelos tribunais em disputas é a mesma da lei, tornando as empresas tão responsáveis quanto se elas mesmas cometessem os erros e infrações, é mais provável que evitem contratar atividades de terceiros.

Os agricultores foram questionados a respeito da responsabilidade civil (liability) em situações de risco como: i) 'de quem é a responsabilidade se um funcionário da empresa contratada (terceirizada) se machuca na sua propriedade?', ii) 'de quem é a responsabilidade se um funcionário de empresa contratada pulverizar a propriedade do vizinho?', iii) 'se a empresa terceirizada não paga o salário ou impostos a seus funcionários durante o período que está prestando serviços para você; quem é responsável se o caso for para os tribunais?', e iv) 'se a empresa terceirizada não respeita as leis sobre tempo extra e salários mínimos, quem é responsável por isso?'.

As disputas judiciais e seus resultados tornam-se também fator influenciador na tomada de decisão dos agentes. Se os produtores percebem risco e incerteza nas decisões do sistema judiciário, tendem a diminuir a exposição ao risco e integrar as atividades.

No Brasil, na pesquisa realizada houve muita divergência de opiniões em relação à responsabilidade de serviços terceirizados. Na questão sobre acidentes de funcionários de prestadores de serviços contratados, cinco dos nove produtores rurais acreditam que a responsabilidade judicial por esse risco seria do prestador do serviço, três percebem que há corresponsabilidade, e um deles não tem certeza ou opinião sobre a situação. A empresa 
BRService1, administradora do consórcio de colheita de laranja conhece as leis e sabe da coresponsabilidade.

No Brasil, a pulverização contratada ocorre somente na pulverização aérea de defensivos. Portanto, não é uma questão que costuma ir às cortes, ou ser decidida em disputas; na verdade, os relatos são que esses tipos e problemas acabam ficando sem solução. Entretanto, na questão a respeito da pulverização e deriva para propriedades vizinhas, cinco produtores dos nove entrevistados acreditam que a responsabilidade seria do dono da terra, o contratante; dois que seria um problema de corresponsabilidade, um que o prestador de serviços deveria ser responsabilizado e um acredita que ninguém seria responsabilizado.

A percepção dos produtores rurais nas questões sobre quem seria responsável nas situações em que a empresa terceirizada não paga o salário ou impostos a seus funcionários durante o período que está prestando serviços para a empresa; ou se a empresa terceirizada não respeita as leis sobre hora extra e salários mínimos, foi a seguinte: caso se tornasse uma disputa judicial, seis dos nove produtores acreditam que ambos são responsáveis judicialmente, dois acreditam que somente o prestador de serviços seria afetado e um não têm certeza. $\mathrm{O}$ consórcio nesta questão também acredita na corresponsabilidade.

Ou seja, de alguma forma os produtores rurais sabem que existe responsabilidade judicial ao contratarem, mas muitas vezes essa percepção vem da justiça trabalhista, tanto por terem se envolvido em disputas trabalhistas ou por conhecerem pessoas que já se prejudicaram em disputas que envolvem a mão de obra.

Dos produtores rurais que participaram do estudo, seis deles (BR2, BR3, BR4, BR6, BR7 e BR9) já deixaram de contratar empresas e serviços terceirizados por receio de se envolverem com empresas desconhecidas e acabarem assumindo riscos por atividades que não estavam sob direção direta deles. As atividades foram diversas, mas existe um consenso a respeito de buscar referências e histórico da prestadora de serviços, bem como informações acerca de idoneidade e profissionalismo. Muitos também já sofreram processos trabalhistas e a ideia de terem funcionários que podem alegar vínculo trabalhista com a operação deles pode impedir que a opção pela terceirização seja uma decisão simples, é preciso considerar o sistema judiciário e os riscos que assumem ao contratarem, por isso optam por conhecidos, na maioria das vezes.

Alguns deles nem mesmo consideram alguns tipos de contratos, de prestação de serviço ou de trabalho, por medo de serem responsabilizados judicialmente indevidamente em algumas situações. O produtor de BR2 relatou que deixou de contratar mais funcionários, especialmente temporários, porque tem receio de ser novamente processado injustamente e ter 
problemas trabalhistas: 'fui processado porque um dos funcionários alegou depois de trabalhar 18 anos na minha propriedade que não tinha hora de almoço, e como eu não tinha registros para provar meu advogado optou por um acordo, o filho desse mesmo homem tinha sido contratado para arrumar uma cerca e entrou com um processo dizendo que trabalhou na minha fazenda anos sem registro, sendo que o trabalho havia durado no máximo uma semana'.

Esse relato levanta outro fator que pode gerar incerteza no ambiente de negócios: o sistema judiciário, uma vez que as decisões não podem ser previstas, as partes optam por não se engajarem em transações que não conseguem antever o resultado, assunto que será discutido no próximo tópico da percepção do sistema judiciário do Brasil pelos produtores rurais.

Para enfatizar a questão do risco e incerteza foram adicionadas mais questões a respeito. Questões como: 'se você contratasse um prestador de serviços independente e ela enfrentasse problemas legais enquanto prestando serviços para você, você seria responsabilizado na justiça?' e 'se você fosse processado legalmente devido a um problema do prestador de serviços você acredita que seria considerado culpado?' foram feitas usando uma escala likert de cinco pontos.

Ambas as questões têm resposta média negativa, como mostra a Tabela 15, a seguir, significando que sim, os produtores no geral acreditam que seriam responsabilizados por erros, problemas e negligência de terceiros, enquanto prestando serviços em suas propriedades, mostrando, dessa forma, que assumem um risco ao contratarem serviços de terceiros.

Tabela 15: Responsabilidade ao contratar terceiros

\begin{tabular}{|c|c|c|}
\hline Responsabilidade & Resultado médio & Desvio Padrão \\
\hline $\begin{array}{c}\text { Seria responsabilizado nos tribunais por } \\
\text { negligencia ou erro da empresa terceirizada. }\end{array}$ & 2,10 & 0,88 \\
\hline $\begin{array}{c}\text { Seria culpado caso fosse processado por } \\
\text { problema da empresa terceirizada. }\end{array}$ & 2,20 & 0,92 \\
\hline
\end{tabular}

Fonte: elaborado pela autora (2018) 


\subsubsection{Sistema judiciário no Brasil}

\subsubsection{Intervenções judiciais}

Quando as empresas enfrentam intervenções judiciais, frequentemente podem mudar sua estratégia, de forma a evitar problemas futuros. Cumpre ressaltar que foram elas que motivaram, inicialmente, o estudo do sistema judiciário afetando as estruturas de governança das firmas.

Retomando as intervenções motivadoras da tese citadas na introdução desta pesquisa, tem-se: os Termos de Ajustamento de Conduta impostos a empresas do setor sucroenergético e citrícola, bem como as ações judiciais movidas pelo Ministério Público do Trabalho contra uma usina que decidiu terceirizar o plantio e a colheita da cana-de-açúcar e a ação contra as indústrias citrícolas que teve como resultado além de pagamento de multas a proibição de terceirização nas atividades de plantio, cultivo e colheita de laranja, em terras próprias ou de terceiros no território nacional.

No Brasil, é comum relatos sobre intervenções judiciais, principalmente quando envolve mão de obra. No caso citado no tópico de incertezas, em que o produtor rural BR2 do Estado de São Paulo foi processado pelo colaborador que trabalhava com ele há 18 anos e pelo filho que foi contratado como temporário, o produtor diz que tem evitado esse tipo de contrato, além das muitas despesas para ter provas e garantir que cumpre com todas as suas obrigações trabalhistas. Ele diz que o sistema judiciário no Brasil é muito parcial e tendencioso em assuntos como esse, o que o forçou a fazer um acordo; o sucesso deste tipo de ação judicial contra empregadores segundo ele pode incentivar outros a agirem de má fé para conseguir dinheiro fácil.

Outra propriedade no Paraná, BR6, teve problema parecido, sofreu uma ação trabalhista em que um prestador de serviços ficou três meses realizando um serviço e alegou que trabalhava muito tempo na propriedade anteriormente e sem registros. $\mathrm{O}$ produtor também foi orientado pelos advogados a fazer acordo, pois sabiam que a probabilidade de o tribunal ser tendencioso era alta. Após esse episódio, a proprietária da fazenda evitou contratar terceiros e funcionários temporários por mais de dez anos; somente em 2018 voltou a contratar, após a mudança da lei.

O produtor rural de BR3 com atividades no Mato Grosso relatou uma ação judicial por um incêndio criminoso em sua propriedade, porém a propriedade era arrendada para uma usina no estado de São Paulo, como era o dono da propriedade foi responsabilizado e teve que 
pagar uma alta multa e reflorestar a área, mesmo não sendo o responsável. Fez um acordo com a usina, que era efetivamente a responsável, para ser reembolsado, mas de qualquer forma o tempo gasto na ação e com advogados fez com que ele não tenha planos de expandir sua operação para o estado, uma vez que 'aumentaria a dor de cabeça'.

Outros relataram intervenções menos significativas, como a burocracia para tomar decisões e ameaças de funcionários de 'entrar na justiça'.

No estado de Mato Grosso, BR8, uma consultoria que trabalha com inúmeros produtores rurais e com prestadores de serviços tem uma estratégia para evitar problemas judiciais com terceiros com os relatados acima, visto que ela mesma já enfrentou problemas judiciais. Para evitar que a empresa se responsabilize pelos erros de terceiros, ou algum funcionário da empresa contratada alegue que trabalha para eles, todos os documentos e comprovantes de pagamentos e guias de recolhimento de INSS (Instituto Nacional do Seguro Social) dos terceiros é verificado antes de pagar pelos serviços contratados. A estratégia tem se mostrado eficiente, porém gera um trabalho extra ao ter que verificar e fiscalizar o cumprimento das leis de perto; no caso da consultoria, há funcionários administrativos suficientes para executarem a verificação.

Em vista disso, percebe-se que o sistema judiciário e as intervenções que as empresas sofrem afetam realmente suas estratégias, e no caso de ações judiciais que no ponto de vista do produtor trazem resultados parciais e tendenciosos, é provável que a mudança estratégica não seja positiva, como no caso do produtor que decide não contratar mais funcionários, ou do que decide não expandir seus negócios, ou, ainda, do que tem que investir recursos em fiscalizar toda a operação do terceiro para garantir que não enfrente novos problemas judiciais. Essas mudanças estratégicas induzidas por um ambiente judicial incerto aumentam os custos de transação e as empresas tendem a integrar verticalmente as atividades e até optar por diminuir suas atividades produtivas.

\subsubsection{Nova Lei}

No Brasil, a lei que torna a ampla terceirização permitida e regula a atividade é recente, e o palpite dos produtores rurais é que a lei traga desenvolvimento para a área de serviços na agricultura, que impulsione o surgimento de empresas terceirizadas especializadas, assim como existem associações e empresas de serviços na Argentina, Uruguai e Estados Unidos, e então a prática seja mais amplamente adotada em território nacional. 
A reforma das leis trabalhistas também empolga os produtores rurais que, segundo eles, sofrem constantes ameaças e intervenções judiciais por causa da parcialidade dos tribunais e do paradigma solidarista da justiça no Brasil, que tenta equilibrar o poder entre as partes em disputas judiciais.

Os produtores não são específicos ao falarem dos benefícios da nova lei, mas declaram que a lei deve favorecer a profissionalização dos serviços na agricultura e, portanto, contribuir para o desenvolvimento do agronegócio.

\subsubsection{Percepção do Sistema judiciário do Brasil}

A pesquisa tem objetivo de relacionar a decisão estratégica em relação a estrutura de governança da propriedade rural com as intervenções no sistema judiciário e a incerteza que tais intervenções podem causar no ambiente de negócios. No entanto, mais que as intervenções isoladas, o sistema judiciário e sua atuação como um todo podem influenciar positiva ou negativamente um ambiente de negócios. Portanto, assim como as instituições importam, a percepção dos atores em relação a essas instituições é, da mesma forma, relevante.

Os agricultores do estudo de caso ponderaram na pesquisa sobre os atributos do sistema judiciário, sobre a confiança que têm em mecanismos de resolução de disputas e sobre decisões das cortes em disputas que envolvem contratação de serviços de terceiros.

O sistema judiciário é uma parte do ambiente institucional de um país, que pode diminuir a incerteza e aumentar a confiança das partes no sistema de resolução de disputas para que as partes possam transacionar com desconhecidos e, dessa forma, desenvolver a economia de forma mais ampla do que se as transações ocorressem somente entre partes conhecidas.

O Poder Judiciário no Brasil é regulado pela Constituição Federal nos seus artigos 92 a 126. Ele é constituído de diversos órgãos, como o Supremo Tribunal Federal (STF), que tem como função principal zelar pelo cumprimento da Constituição e, abaixo dele, o Superior Tribunal de Justiça (STJ), responsável por fazer uma interpretação uniforme da legislação federal. O País tem um sistema legal com origem na lei civil (civil law), as leis escritas estão em primeiro plano nos processos de decisão judicial. Os casos no âmbito jurídico brasileiro são julgados baseados em interpretação de normas presentes em leis, códigos e Constituição Federal. Apesar de ser prioritariamente baseado na lei civil, o sistema judiciário brasileiro também tem influência da lei comum, que usa análise jurisprudencial, mas no País ela é usada 
para não haver casos com situações parecidas e decisões discrepantes; ou seja, não cabe aos juízes legislarem baseado nos costumes, como funciona na common law.

A análise do direito e da economia busca estudar esses sistemas e leis e sua eficiência na resolução de disputas, portanto, tal análise usualmente é feita em relação à qualidade, envolve o tempo de resolução de disputas, o custo envolvido nessas resoluções a burocracia e a facilidade de acesso ao sistema. Os agricultores e prestadores de serviços foram confrontados com questões sobre esses atributos para responderem, por meio de uma escala likert de cinco pontos, conforme pode ser verificado no instrumento do estudo de casos. Os resultados podem ser verificados na Tabela 16, que apresenta o resultado médio e o desvio padrão da percepção que os produtores têm a respeito dos atributos sendo que, na escala, quanto maior o resultado, melhor a percepção de qualidade que os produtores têm do sistema judiciário brasileiro.

Tabela 16: Atributos do Sistema judiciáriodo Brasil na percepção dos agricultores

\begin{tabular}{|c|c|c|}
\hline Atributos Sistema judiciário & Resultado médio & Desvio Padrão \\
\hline $\begin{array}{c}\text { Qualidade judicial satisfatória (tempo, custo, } \\
\text { acesso, previsibilidade, imparcialidade) }\end{array}$ & 2,20 & 1,03 \\
\hline Rapidez/tempo na solução de disputas & 2,80 & 0,92 \\
\hline Custo de utilizar o sistema judiciário & 2,10 & 0,74 \\
\hline Burocracia do sistema judiciário & 2,40 & 1,35 \\
\hline Acesso ao sistema judiciário & 4,10 & 0,99 \\
\hline
\end{tabular}

Fonte: elaborado pela autora (2018)

No Brasil, a percepção dos produtores rurais em relação à qualidade geral do sistema judiciário tem um resultado negativo, considerando que o ponto neutro seria o 2,5 e o resultado de 2,2 está abaixo. O desvio padrão é de 1,03 em torno do resultado médio. Nenhum dos produtores rurais e das empresas prestadoras de serviço concordou totalmente com a qualidade satisfatória do sistema; com efeito, três discordaram totalmente, três discordaram, três se mantiveram neutros e um concordou que o sistema judiciário brasileiro apresenta qualidade satisfatória em relação a tempo, custo, acesso, previsibilidade e imparcialidade.

Os custos tiveram resultados negativos também, de 2,1, significando que os produtores acreditam que seja caro processar ou se defender de uma ação judicial e o número de procedimentos burocráticos foi considerado 2,4 , ou seja, existe burocracia, contudo, ela não é excessiva. 
O atributo 'rapidez na solução de disputas', obteve resultado acima do ponto neutro da escala likert, com um resultado de 2,8, ligeiramente maior que a percepção da qualidade geral, o que muitos destacaram e talvez justifique essa superioridade é que a agilidade é diferente, dependendo do tribunal utilizado (tribunal do trabalho vs tribunal civil).

No Brasil, o sistema judiciário é composto por unidades diferentes: Justiça Federal (comum) incluindo os juizados especiais federais, e a Justiça Especializada composta pela Justiça do Trabalho, a Justiça Eleitoral e a Justiça Militar. No âmbito estadual, a Justiça Estadual (comum) é composta pelos juízes de Direito (que atuam na primeira instância) e pelos chamados desembargadores, que atuam nos tribunais de Justiça (segunda instância), além dos juizados especiais cíveis e criminais. A ela cabe processar e julgar qualquer causa que não esteja sujeita à competência de outro órgão jurisdicional (Justiça Federal comum, do Trabalho, Eleitoral e Militar). O que os produtores percebem é que se o processo se enquadra na Justiça do Trabalho existe uma celeridade ao resolver as disputas, porém, nos tribunais de justiça comum, os prazos são maiores.

Os custos tiveram resultados negativos também, de 2,1, significando que os produtores acreditam que seja caro processar ou se defender de uma ação judicial e o número de procedimentos burocráticos foi considerado 2,4 , ou seja, existe burocracia, contudo ela não é excessiva.

O único resultado positivo foi em relação ao acesso ao sistema judiciário, que foi considerado acima do ponto de simplificado, com uma média de 4,1, o que demonstra mostra que os produtores acreditam que é simples acessar o sistema judiciário.

Todavia, quando a questão é sobre que mecanismo de resolução de disputas, os produtores confiariam primeiro ao tentar resolver a disputa; somente um dos dez respondentes escolheu ir aos tribunais como primeira opção, os outros ficaram igualmente divididos entre mediação (três respondentes), arbitragem (três respondentes) e não recorreriam a nenhuma das opções (três respondentes).

A popularização de mecanismos alternativos aos tribunais para a resolução de disputas tem se popularizado no País após as recentes reformas legais, no entanto ainda não é um mecanismo conhecido em disputas menores. Após a reforma da arbitragem, em 2015, com a Lei n ${ }^{0} 13.129$ (Brasil, 2015), o presidente do Centro de Arbitragem e Mediação da Câmara de Comércio Brasil-Canadá (CAM-CCBC) relatou que, em 2017, cresceu em 26\% a demanda por processos de arbitragem e os valores envolvidos nos procedimentos caíram $24 \%$; ainda segundo o presidente, as empresas estão verificando que a arbitragem se presta a casos médios, e isso é bom para a arbitragem e para o Brasil (Rodas, 2018). Mesmo com esse 
crescimento, a arbitragem ainda se restringe principalmente a grandes empresas no País, pela falta de conhecimento das partes sobre o assunto e também pelo acesso a câmaras arbitrais.

A mediação também tem sido mais utilizada, apesar de não haver dados estatísticos; porém a maioria dos casos ainda é conduzida pelos Centros Judiciários de Solução de Conflitos e Cidadania (Cejuscs), que faz parte do Tribunal de Justiça, em que o mecanismo de mediação é utilizado com a conciliação antes de a disputa ir para o tribunal comum. Ressaltese que as Câmaras Privadas de Conciliação e Mediação foram permitidas após 2016 pelo Provimento $n^{\mathrm{o}}$ 2.348/16 (Conselho Superior da Magistratura, 2016).

Apesar do desconhecimento de muitos entrevistados a respeito das informações, e de ter sido dado uma breve introdução ao assunto durante a entrevista, eles foram perguntados a respeito da confiança que as partes têm nos mecanismos de resolução de conflitos tradicionais, o tribunal de justiça e nos outros mecanismos, a mediação e arbitragem. Os produtores também expressaram o grau de confiança que tem na imparcialidade dos tribunais e o quanto tempo os tomadores de decisão confiam que o tribunal faz o que é certo.

Nessas categorias, a escala likert foi de quatro pontos, para evitar o ponto neutro, com exceção da questão da quantidade do tempo que confiam que os tribunais farão o que é certo. Os resultados são vistos na Tabela 17:

Tabela 17: Grau de confiança nos mecanismos de solução de disputas

\begin{tabular}{|c|c|c|}
\hline \multicolumn{1}{|c|}{ Grau de Confiança $^{1}$} & Resultado médio $^{1}$ & Desvio Padrão \\
\hline Confiança mediação & 2,2 & 0,63 \\
\hline Confiança arbitragem & 2,3 & 0,67 \\
\hline Confiança tribunais e juízes & 2,1 & 0,57 \\
\hline Confiança na imparcialidade dos tribunais & 1,8 & 0,79 \\
\hline Quanto do tempo confia nos tribunais* & 1,8 & 0,79 \\
\hline${ }^{1}$ : escala likert de 4 pontos & & \\
\hline Foscala likert de 3 pontos & & \\
\hline Fonte: elaborado pela autora (2018) & & \\
\hline
\end{tabular}

O mecanismo que apresentou o maior grau de confiança foi a arbitragem, com média 2,3. A mediação veio em seguida, com 2,2 , e a confiança nos tribunais e juízes com a menor pontuação, 2,1. Todos eles apresentam grau ligeiramente positivo; no entanto, o resultado que vale a pena prestar atenção é que mesmo grande parte dos respondentes não tendo muita informação ou conhecimento sobre a mediação e arbitragem, o grau de confiança nesses mecanismos foi maior que no sistema de justiça comum, sobre o qual os respondentes têm mais informação. 
Quanto à confiança na imparcialidade das decisões judiciais o resultado foi negativo, com resultado de 1,8, ou seja, os respondentes acreditam que os tribunais sejam tendenciosos ao tomarem suas decisões, resultado que apoia a pesquisa bibliográfica em que o paradigma solidarista do sistema judiciário brasileiro tende a favorecer as partes que apresentam menor poder na relação, principalmente no que envolve mão de obra diretamente contratada ou terceirizada.

Já para o quanto do tempo acreditam que os tribunais tomam as decisões corretas o resultado foi positivo, 1,8 (cumpre esclarecer que, apesar de ser o mesmo resultado da imparcialidade, aqui há uma escala de três pontos).

Em suma, o resultado da percepção do sistema judiciário do Brasil pelos agricultores e prestadores de serviços é negativo, expondo as fraquezas do sistema judiciário do País em promover segurança ao ambiente para que as pessoas possam transacionar sem preocupações porque o sistema faria cumprir os acordos e leis.

\subsubsection{Conclusão}

No Brasil, a maioria dos produtores que terceiriza, o faz em situações que realmente apresentam necessidade; apesar de a decisão ser estratégica, por vezes é considerada uma das últimas opções deles.

Quando se observa a cultura de grãos, identifica-se a maioria dos produtores integrados nas atividades relacionadas a essa cultura, quando esses produtores terceirizam é uma das atividades e somente parte dela; no estudo, constatou-se que três produtores de soja terceirizam parcialmente uma das atividades e outro terceiriza uma atividade especializada dependente de alto investimento (pulverização aérea).

O Quadro 15, apresentado a seguir, mostra um resumo das variáveis para as atividades nas culturas de grãos que constroem a arquitetura organizacional de cada caso discutido no Brasil. 
Quadro 15: Tomada de decisão dos produtores rurais do Brasil na cultura de grãos.

\begin{tabular}{|c|c|c|c|c|c|c|c|c|}
\hline & \multicolumn{3}{|c|}{ DIREITO DECISÃO } & \multirow{2}{*}{$\begin{array}{c}\text { VALOR } \\
\text { Valor Criado }\end{array}$} & \multicolumn{4}{|c|}{ Fatores que afetam a INCERTEZA } \\
\hline Produtor & Terceiriza & Terceiriza grãos & Presta serviços & & $\begin{array}{c}\text { Qualidade e } \\
\text { Confiança no } \\
\text { Sistema Judicial }^{1}\end{array}$ & $\begin{array}{c}\text { Corresponsabilidade } \\
\text { judicial }\end{array}$ & $\begin{array}{c}\text { Já deixou de contratar } \\
\text { por responsabilidade } \\
\text { judicial }\end{array}$ & \begin{tabular}{|c|} 
Responsabilizado \\
judicialmente por erro \\
de terceiros prestando \\
serviço na propriedade
\end{tabular} \\
\hline$B R 1$ & sim & não & $\operatorname{sim}$ & 0 & 2,2 & corresponsabilidade & sim & 2 \\
\hline$B R 2$ & $\operatorname{sim}$ & $\begin{array}{c}\text { sim, pulverização } \\
\text { aérea }\end{array}$ & $\operatorname{sim}$ & 0 & 2,5 & corresponsabilidade & sim & 2 \\
\hline$B R 3$ & Não & não & não & -1 & 3,3 & não & sim, na construção civil & 2 \\
\hline BR4 & $\operatorname{sim}$ & - & não & 0 & 3,3 & $\begin{array}{c}\text { não para lesão, } \\
\text { corresponsabilidade } \\
\text { para paga mento, } \\
\text { impostos e direitos } \\
\end{array}$ & $\operatorname{sim}$ & 3 \\
\hline BR5 & $\operatorname{sim}$ & parcialmente & não & 3 & 2,9 & corresponsabilidade & $\begin{array}{l}\text { nunca pensou a } \\
\text { respeito }\end{array}$ & 3 \\
\hline BR6 & $\operatorname{sim}$ & não & não & 2 & 2,1 & $\begin{array}{c}\text { não sa be para lesão, } \\
\text { corresponsabilidade } \\
\text { para paga mento, } \\
\text { impostos e direitos }\end{array}$ & $\operatorname{sim}$ & 2 \\
\hline$B R 7$ & $\operatorname{sim}$ & não & $\operatorname{sim}$ & 1 & 2,7 & não & $\operatorname{sim}$ & 2 \\
\hline$B R 8$ & $\operatorname{sim}$ & parcialmente & não & 1 & 2,6 & $\begin{array}{c}\text { não para lesão, } \\
\text { corresponsabilidade } \\
\text { para paga mento, } \\
\text { impostos e direitos } \\
\end{array}$ & $\operatorname{sim}$ & 1 \\
\hline$B R 9$ & $\operatorname{sim}$ & parcialmente & não & 2 & 2,3 & não & $\operatorname{sim}$ & 3,5 \\
\hline
\end{tabular}

Fonte: elaborado pela autora (2019).

$\mathrm{Na}$ laranja, todos os três produtores do estudo terceirizam a colheita manual do fruto, e dizem que por ser uma atividade intensiva em mão de obra não poderiam integrar verticalmente e contratar todos esses colaboradores por um tempo determinado, pelo menos não como era a lei antigamente. A proibição da terceirização de atividades fins no Brasil, incentivou o surgimento de 'gatos ${ }^{86}$ e empreiteiras de mão de obra irregulares no passado, deixando poucas opções de empresas idôneas para os produtores; iniciativas como o consórcio de colheita de laranja relatados são a exceção.

O ambiente institucional não é percebido como fator positivo na agricultura; a percepção dos agricultores é que o sistema judiciário não tem qualidade satisfatória, e que os tribunais agem com parcialidade ao resolver disputas. Em outras palavras, o ambiente institucional, que deveria ser responsável por diminuir a incerteza e reduzir os custos de transação, acaba atuando de forma contrária. No Brasil também não existem disponíveis mecanismos na agricultura que transfiram os riscos trabalhistas e com terceiros por meio de seguros particulares. Mecanismos particulares de resolução de conflitos, apesar de existirem, ainda não são muito populares em disputas menores no País.

8 Palavra popularmente utilizada para empresas não registradas, exercendo atividade informalmente. 
As novas leis, no entanto, trazem boas expectativas aos produtores; eles esperam que mais empresas terceirizadas especializadas surjam no mercado para que a contratação de serviços possa ser uma alternativa estratégica viável, para que possam livremente escolher em que investir seus recursos, garantindo se desejarem o acesso a tecnologias modernas sem necessidade de imobilizar capital na propriedade dos equipamentos.

\subsection{Análise comparativa entre os estudos de caso: Brasil e Estados Unidos}

\subsubsection{Estruturas de governança}

Analisando os atributos da transação, conforme sugere Williamson (1979, 1985, 1991a, 1993, 1996, 2000), ou a arquitetura do acordo, como recomenda Sykuta (2012) podese comparar a opção pela terceirização ou pela integração vertical das atividades produtivas.

No estudo de caso do Brasil, oito dos nove produtores rurais terceirizaram alguma atividade, seja nas culturas principais ou auxiliares (coadjuvantes/secundárias); decompondo essa porcentagem, tem-se: dois deles terceirizam em culturas complementares como na canade-açúcar, pecuária e produção de madeira; três na cultura da laranja e três na soja, em complementação a atividades integradas verticalmente.

No Brasil, portanto, os agricultores que terceirizam o fazem ou em culturas que têm necessidade intensiva de mão de obra (como a colheita manual da cultura da laranja, em que a frequência de transações é muito baixa; logo, os custos de transação envolvidos não justificariam a integração da atividade) ou em culturas complementares às suas principais, considerando além dos custos de transação na opção também o ganho potencial da especialização mediante a divisão do trabalho ou de uma coordenação mais eficiente dos esforços produtivos, conforme ressalta Cheung (1983). Existem ainda os que terceirizam parcialmente uma atividade que é integrada verticalmente, para complementarem a capacidade produtiva. Dessa forma, não ficam totalmente dependentes de terceiros, de forma que fiquem expostos a problemas de hold up.

Nos Estados Unidos, o estudo de caso foi conduzido somente na produção de grãos. As propriedades que terceirizam alguma atividade são cinco das oito propriedades e elas são prioritariamente produtoras de grãos. A maioria das atividades terceirizadas envolve equipamentos de alto valor, com alta tecnologia embarcada, porém, que não apresentam alta especificidade de ativo, além de serem realizadas esporadicamente (baixa frequência), como a aplicação de fertilizantes, ou a colheita de grãos. 
Ao comparar os dados gerais de que, no Brasil, uma das nove propriedades rurais optou por ser totalmente integrada e, nos Estados Unidos, três das oito fazendas integram verticalmente todas as atividades se pode inferir, precipitadamente, que no Brasil existe mais terceirização do que nos Estados Unidos. No entanto, o método de estudos de caso permite visualizar em profundidade que a taxa de terceirização, quando ocorre nos Estados Unidos, acaba sendo superior porque a decisão americana da terceirização considera a contratação total de toda a atividade, não somente suplementar à capacidade do produtor rural, como frequentemente ocorre no Brasil.

Ademais, ao comparar o total de terceirização, não é considerado que no Brasil levouse em conta um número maior de culturas, diferentemente dos Estados Unidos, em que o estudo foi realizado somente em grãos. O maior número de culturas justifica-se porque as propriedades rurais brasileiras são diversificadas e têm, em média, três culturas diferentes na propriedade e nos EUA as propriedades da região do estudo de casos eram somente de grãos.

Levando em consideração somente a cultura de grãos nas propriedades do Brasil e Estados Unidos um cenário diferente se apresenta: enquanto, no Brasil, duas das oito fazendas contratam serviços terceirizados, nos Estados Unidos, cinco dos oito produtores rurais contratam algum serviço de terceiros, como mostra o Gráfico 7, na página seguinte.

A comparação entre culturas semelhantes é importante porque as operações produtivas necessárias também são similares. No Brasil, contudo, os produtores de grãos investem em dupla safra, por causa das condições climáticas favoráveis, o que amplia a especificidade temporal de algumas atividades, aumentando os custos de transação e, por conseguinte, a integração vertical. 
Gráfico 7: Estruturas de governança e prestadores de serviços em grãos no Brasil e Estados Unidos

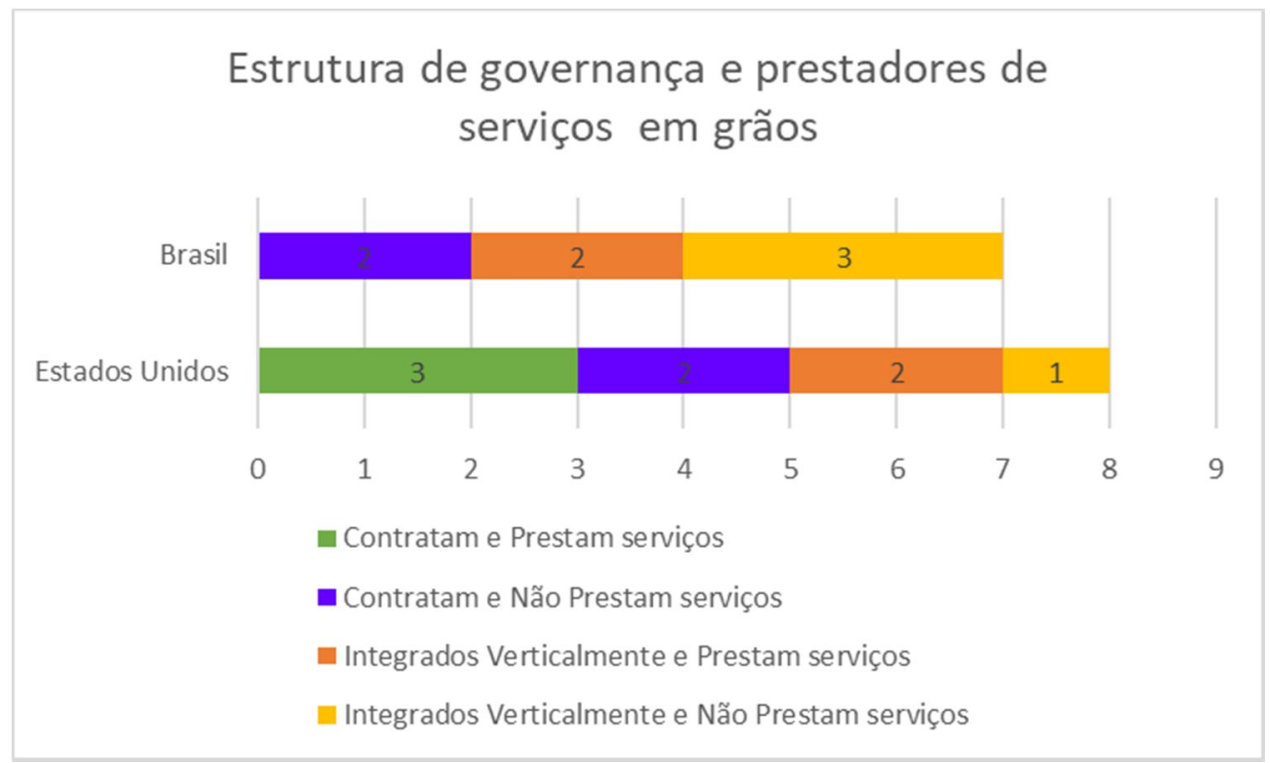

Fonte: elaborado pela autora (2019)

As atividades terceirizadas em cada um dos países encontram-se no Quadro 16, apresentado a seguir. No Brasil, para a soja os serviços são plantio e colheita, além de aplicação de defensivos aéreos em grandes propriedades. Nos Estados Unidos, existem as opções de custom farming, em que os prestadores de serviços oferecem desde a execução de uma atividade a conduzir e gerenciar todas as atividades da propriedade; outros oferecem serviços especializados somente em colheita de grãos, pulverização de defensivos, seja por via aérea ou terrestre, aplicação de fertilizante a taxas variáveis, bem como aplicação de corretivos de acidez do solo etc.

\section{Quadro 16: Atividades terceirizadas no Brasil e nos Estados Unidos}

\begin{tabular}{|c|c|c|}
\hline & Brasil & Estados Unidos \\
\hline \multirow{9}{*}{ 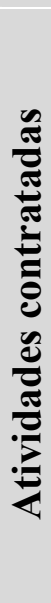 } & Colheita de Laranja & Custom farming (agricultura personalizada) \\
\hline & Colheita de grãos & Colheita de grãos \\
\hline & Plantio de grãos & Pulverização terrestre de defensivos \\
\hline & Silagem de grãos & Pulverização aérea de defensivos \\
\hline & $\begin{array}{l}\text { Plantio, Corte, Carregamento e Transporte } \\
\text { de cana-de-açúcar }\end{array}$ & $\begin{array}{l}\text { Aplicação de fertilizantes secos e úmidos } \\
\text { (tecnologia de aplicação variável) }\end{array}$ \\
\hline & Pulverização aérea de defensivos & Aplicação de corretivo \\
\hline & Corte de madeira & Amostragem de solos \\
\hline & Amostragem de solos & \\
\hline & Outros serviços: cercas, construção, etc & Outros serviços: cercas, construção, etc \\
\hline
\end{tabular}

Fonte: elaborado pela autora (2018) 


\subsubsection{Valor Criado}

Ao decidir qual será a arquitetura organizacional das transações, os tomadores de decisão analisam qual será o valor criado caso a atividade seja integrada verticalmente ou contratada de terceiros, conforme indicado por Sykuta (2012). O valor criado na transação terceirizada é percebido diferentemente por cada agente, bem como as especificidades dos ativos entre outros fatores. A especificidade de ativos (Williamson (1985, 1991b, 1991a, 1996) e a criação de valor nos acordos (Sykuta, 2012) são conceitos interrelacionados; quando existem ativos específicos envolvidos, os custos de transação são maiores; logo, há menor criação de valor em acordos de terceirização.

O índice médio de valor criado nos Estados Unidos em transações terceirizadas na agricultura foi de 0,67 , enquanto no Brasil esse índice foi de 0,87 , índices que dão suporte ao maior número de casos que optam por contratos de terceirização no Brasil. No Quadro 17, apresentado na página seguinte, os prós e contra dos dois países são sumarizados. 
Quadro 17: Valor Criado na Terceirização no Brasil e Estados Unidos

\begin{tabular}{|c|c|c|}
\hline & \multicolumn{2}{|c|}{ Valor Criado na Terceirização } \\
\hline & Positivo & Negativo \\
\hline 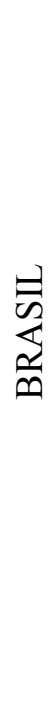 & $\begin{array}{l}\text { - Não imobilização de recursos } \\
\text { financeiros em parque de máquinas } \\
\text { - Foco em atividades mais importantes } \\
\text { - Economia de recursos em manutenção } \\
\text { - Delegar gestão de funcionários e } \\
\text { também o cumprimento e preocupações } \\
\text { com requisitos das leis trabalhistas. } \\
\text { - Juros altos para aquisição de } \\
\text { - } \quad \text { Acesuipamentos a novas tecnologias } \\
\text { - Mão de obra rural escassa e cara }\end{array}$ & $\begin{array}{l}\text { - Desempenho inferior do prestador de } \\
\text { serviços } \\
\text { - } \quad \begin{array}{l}\text { Especificidade temporal das atividades } \\
\text { por causa da double crop }\end{array} \\
\text { - } \\
\text { Pouca disponibilidade de prestadores de } \\
\text { serviços profissionais e idôneos } \\
\text { - Alta incidência de impostos sobre os } \\
\text { prestadores de serviços encarecem o } \\
\text { preço. } \\
\text { - Riscos jurídicos da corresponsabilidade }\end{array}$ \\
\hline 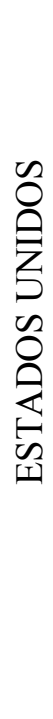 & $\begin{array}{l}\text { - } \quad \text { Especialização do prestador de serviços } \\
\text { - Rapidez de execução de atividades, } \\
\text { simultaneidade na execução. } \\
\text { - Foco em atividades mais importantes } \\
\text { - Menor número de colaboradores } \\
\text { necessários } \\
\text { - Economia de investimentos iniciais } \\
\text { - Diminuição de custos fixos com } \\
\text { - } \begin{array}{l}\text { Acesso a novas tecnologias e máquinas } \\
\text { modernas }\end{array}\end{array}$ & $\begin{array}{l}\text { - Alto preço do serviço contratado } \\
\text { - Especificidade temporal de algumas } \\
\text { atividades } \\
\text { - Probabilidade de atrasos } \\
\text { - Renunciar o direito de controle e } \\
\text { decisão }\end{array}$ \\
\hline
\end{tabular}

Fonte: elaborado pela autora (2018)

Ao focalizar cada um dos casos, conforme mostrado no Quadro 18, ratifica-se que o valor criado percebido pelos tomadores de decisão exerce papel importante na decisão pela melhor estrutura de governança da empresa. Quando os produtores rurais não enxergam valor criado (negativo) na terceirização, eles são integrados verticalmente. Quando eles consideram o valor criado positivo na desintegração de atividades, na maioria das vezes eles terceirizam alguma atividade. Algumas exceções ocorrem quando o produtor rural do caso presta serviços. Ou seja, o valor criado no acordo é uma variável importante no alinhamento da arquitetura organizacional dos acordos. 
Quadro 18: Valor criado nos casos dos Estados Unidos e Brasil

\begin{tabular}{|c|c|c|c|c|c|c|c|c|}
\hline Produtor & US1 & US2 & US3 & US4 & US5 & US6 & US7 & US8 \\
\hline Terceiriza & não & $\operatorname{sim}$ & $\operatorname{sim}$ & $\operatorname{sim}$ & não & não & $\operatorname{sim}$ & sim \\
\hline Valor Criado & -1 & 0 & 1 & 1 & 3 & 0 & 1 & 0 \\
\hline
\end{tabular}

\begin{tabular}{|c|c|c|c|c|c|c|c|c|c|}
\hline Produtor & $B R 1$ & $B R 2$ & $B R 3$ & $B R 4$ & $B R 5$ & $B R 6$ & $B R 7$ & $B R 8$ & $B R 9$ \\
\hline Terceiriza & $\begin{array}{c}\text { sim- laranja } \\
\text { não-grãos }\end{array}$ & sim & não & sim - laranja & parcialmente & $\begin{array}{c}\text { BRASIL - cana } \\
\text { não - grãos }\end{array}$ & $\begin{array}{c}\text { sim - silagem } \\
\text { não - grãos }\end{array}$ & parcialmente & parcialmente \\
\hline Valor Criado & 0 & 0 & -1 & 0 & 3 & 2 & 1 & 1 & 2 \\
\hline
\end{tabular}

Fonte: elaborado pela autora (2019)

\subsubsection{Incerteza e Risco}

$\mathrm{Na}$ tomada de decisão o ambiente institucional desempenha um importante papel, mas ele é, muitas vezes, deixado em segundo plano em pesquisas na área de gestão e economia das organizações. Ele atua como suporte dos acordos, diminui a incerteza e, por conseguinte, os custos de transação do ambiente, permitindo que as partes se engajem em transações fora do escopo da firma. A incerteza é vista como importante atributo, tanto para Oliver Williamson (1985, 1991b, 1991a, 1996) quanto para Michael Sykuta (2012) no alinhamento das transações, seja na economia dos custos de transação ou na arquitetura organizacional.

Seja na definição e cumprimento das leis no sistema judiciário com origem no civil law francês; ou nos costumes e decisão dos juízes do sistema judiciário baseado na common law, é fundamental que as leis sejam adotadas de acordo com os procedimentos estabelecidos, que sejam divulgadas ao público e que sejam cumpridas de forma consistente e imparcial. É imperativo que o sistema judiciário seja baseado em um Estado de Direito que represente todas as partes e que garantam o enforcement dos contratos e direitos de propriedade das partes. O Estado de Direito tem a intenção de garantir que o governo exerça sua autoridade de forma justa, e é crucial para garantir a liberdade e a justiça para o povo de qualquer nação (North, 1991, 1992, 1994, 1999, 2005). Cumpre lembrar que as instituições emergem para reduzir a incerteza ao estruturar as interações humanas. (North, 1991) 
Ao optar pela terceirização de alguma atividade, um dos interesses da firma é delegar parte do direito de decisão e responsabilidades dela a outrem; dessa forma, o gestor pode focar seus recursos em outras atividades que julga indispensáveis, dentro da estrutura da empresa. Todavia, com o viés negativo que o sistema judiciário do Brasil enxergava a terceirização no País, tal transferência do direito de decisão e responsabilidades era considerado uma forma de precarizar a mão de obra, tratando-a como mercadoria e, assim, a prática era vista como uma forma de se esquivar dos direitos dos trabalhadores.

Desse modo, constantemente, empresas que terceirizavam atividades eram autuadas e processadas judicialmente pelo Ministério do Trabalho e enquadradas na Súmula 331 do TST, que proibia a terceirização de atividades-fim, precedente que tinha o intuito de preservar os trabalhadores e seus direitos. No entanto, o que se via na prática eram autuações que não se preocupavam em checar se os funcionários de empresas terceirizadas eram privados de seus direitos, ou se a atividade era realmente fim na cadeia de valor da empresa, ou em situações extremas, se tais autuações não causariam externalidades negativas para outros elos da cadeia de valor, assim como o ocorrido com o processamento de laranja, quando a decisão do tribunal foi de que as indústrias não mais poderiam processar laranja de pomares de terceiros, forçando uma integração vertical a montante na produção de laranjas.

A nova lei no Brasil permite que todas as atividades sejam terceirizadas, independentemente da posição e da importância na cadeia da empresa; desse modo, com a prática autorizada legalmente, agora cabe ao gestor a tomada de decisão. Porém, apesar de delegar e terceirizar a atividade, a empresa ainda é corresponsável por esta, diminuindo então a criação de valor que a opção pela terceirização poderia trazer ao negócio e aumentando a exposição ao risco ao contratar (a incerteza), uma vez que ao terceirizar não tem mais o direito de decisão diretamente sobre os recursos e mão de obra.

Nos Estados Unidos, o gestor que terceiriza uma atividade só é responsável por ela se ele for negligente em alguma informação ou ação que venha a causar danos. Caso contrário, o contratado é diretamente responsável pelas suas ações, erros e negligências, além de haver mecanismos particulares de transferência de risco, como os seguros de responsabilidade civil, que diminuem a exposição a risco dos gestores.

Apesar de a incerteza não ser o atributo mais relevante da transação, ela desempenha papel importante quando se relaciona a transação ao ambiente institucional. A incerteza apresenta relevância para a organização de transações com atributos de investimento mistos, afirma Williamson (1979). Muitas estruturas de governança bilaterais, no caso, contratos e transações no mercado, muitas vezes dão lugar à integração vertical à medida que aumenta a 
incerteza para transações recorrentes. As reduções na incerteza, por sua vez, justificam a mudança de transações na direção oposta: quando a incerteza diminui à medida que uma indústria amadurece, os benefícios da integração diminuem (Williamson, 1979).

No estudo de caso dos dois países, Brasil e Estados Unidos, foram explorados o conhecimento e a percepção da responsabilidade que o contratante tem ao terceirizar uma atividade. A percepção de responsabilidade, ou corresponsabilidade, sobre o serviço do terceiro aumenta a incerteza na transação, de forma a aumentar a probabilidade de destruição de valor caso o terceiro cometa algum erro no desempenho da atividade.

O resultado das questões em escala likert sobre responsabilidade e culpabilidade, caso a empresa terceira cometa algum erro, reforça esse achado, sendo 3,27 a média das respostas nos EUA, acima do ponto de neutralidade (2,5 de 5 pontos). Isto é, nos Estados Unidos os produtores rurais acreditam que provavelmente não seriam responsabilizados ou sentenciado por erro, negligência ou não cumprimento das leis pelos contratados ao prestarem serviço em suas propriedades. O que mostra que o grau de incerteza no ambiente institucional norteamericano não é alto em relação à questão de responsabilidade jurídica sobre o terceiro e este baixo grau de incerteza aumenta a probabilidade de desintegração de atividades.

No Brasil, existem muitas dúvidas e divergência de entendimento a respeito da corresponsabilidade e de quem seria responsabilizado no caso de o contratado enfrentar algum problema devido a erro, negligência ou acidentes. Esse fato deve-se em parte porque a lei é nova e muitos não a conhecem plenamente. Ainda assim, no Brasil os produtores rurais acreditam que se algo, principalmente relacionado à esfera trabalhista, ocorre em sua propriedade, de alguma forma ele será culpabilizado pelo ocorrido; a média das respostas é abaixo do ponto de neutralidade 2,1 e 2,2; indicando que os produtores acreditam que provavelmente seriam responsabilizados caso a empresa terceira contratada responda por algum problema judicial, ou seja, que os tribunais aumentam a incerteza em relação aos contratos, o que torna maior a probabilidade de os produtores rurais integrarem verticalmente o maior número de atividades. Cabe lembrar que a nova lei sobre terceirização ratifica a percepçãos dos agricultores brasileiros de que são corresponsáveis judicialmente.

Os resultados sobre a responsabilidade judicial em serviços terceirizados nos dois países, Brasil e Estados Unidos, são retomados conjuntamente na Tabela 18, a seguir: 
Tabela 18: Responsabilidade judicial em serviços de terceiros no Brasil e Estados Unidos

\begin{tabular}{|l|c|c|c|c|}
\hline & \multicolumn{2}{|c|}{ Estados Unidos } & Brasil \\
\hline Responsabilidade & Resultado médio & Desvio Padrão & Resultado médio & Desvio Padrão \\
\hline $\begin{array}{l}\text { Seria responsabilizado nos tribunais por } \\
\text { negligencia ou erro da empresa terceirizada. }\end{array}$ & 3,27 & 1,01 & 2,10 & 0,88 \\
\hline $\begin{array}{l}\text { Seria culpado caso fosse processado por } \\
\text { problema da empresa terceirizada. }\end{array}$ & 3,27 & 0,90 & 2,20 & 0,92 \\
\hline
\end{tabular}

Fonte: elaborado pela autora (2018)

Dessa forma, a incerteza e o risco que o ambiente institucional traz ao ambiente de negócios do Brasil são maiores que o enfrentado nos Estados Unidos quando se estabelece a estrutura de governança da empresa. Logo, os custos de transação de terceirizar são maiores no Brasil, o que consequentemente diminui o valor criado na decisão de contratar uma atividade. Portanto, na tentativa de evitar essa incerteza, ao decidirem quanto à arquitetura organizacional, os produtores optam, na maior parte do tempo, por integrar verticalmente e manter o direito de decisão e controle da atividade. Por mais que o número de produtores brasileiros do estudo de caso que terceirizem alguma atividade seja maior, o índice de terceirização deles é menor; tais produtores ainda optam pela terceirização somente quando não possuem recursos suficientes para integrar as atividades, ou quando analisam que o custo de integrar a atividade é muito maior que o risco enfrentado ao terceirizar.

Analisando individualmente os casos no Quadro 19, no entanto, o índice de percepção de responsabilidade judicial não apresenta resultados que corroboram que a corresponsabilidade afeta a opção individual de terceirizar as atividades, pois produtores que acreditam que seriam responsabilizados continuaram contratando, e o oposto também ocorreu.

No entanto, nos casos brasileiros os produtores relataram que deixaram de contratar serviços e empresas por causa da corresponsabilidade no Brasil ao terceirizar e, nos Estados Unidos, por sua vez, os produtores prestadores de serviços já deixaram de prestar serviços considerando a responsabilidade judicial, uma vez que nos Estados Unidos a empresa que presta o serviço será responsabilizada em caso de algum erro ou negligência. Esses resultados mostram que a responsabilidade judicial não os impede de contratar, porém os orienta a serem mais diligentes ao tomarem as decisões e ao escolherem os prestadores de serviços. 
Quadro 19: Responsabilidade Judicial nos casos norte-americanos e brasileiros.

\begin{tabular}{|c|c|c|c|c|c|c|c|c|}
\hline & \multicolumn{8}{|c|}{ ESTADOS UNIDOS } \\
\hline Produtor & US1 & US2 & US3 & US4 & US5 & US6 & US7 & US8 \\
\hline Terceiriza & não & $\operatorname{sim}$ & $\operatorname{sim}$ & $\operatorname{sim}$ & não & não & $\operatorname{sim}$ & $\operatorname{sim}$ \\
\hline $\begin{array}{c}\text { Corresponsabilidade } \\
\text { judicial }\end{array}$ & não & não & $\begin{array}{c}\text { corres ponsabilidade } \\
\text { somente para lesão }\end{array}$ & $\begin{array}{l}\text { não, sem certeza } \\
\text { para lesão }\end{array}$ & não & não & $\begin{array}{c}\text { corresponsabilidade } \\
\text { somente para lesão }\end{array}$ & não \\
\hline \begin{tabular}{|c|} 
Responsabilizado \\
judicialmente por \\
erro de terceiros \\
prestando serviço na \\
propriedade $^{1}$
\end{tabular} & 3 & 4,5 & 3 & 3,5 & 2 & 3,5 & 3,5 & 3,5 \\
\hline $\begin{array}{c}\begin{array}{c}\text { Já deixou de } \\
\text { contratar por } \\
\text { responsabilidade } \\
\text { judicial }\end{array} \\
\end{array}$ & não & $\begin{array}{c}\text { sim, em atividades } \\
\text { arriscadas fora da } \\
\text { agricultura }\end{array}$ & não & não & $\begin{array}{c}\text { sim, deixou de } \\
\text { prestar serviços } \\
\text { por causa do risco }\end{array}$ & sim & não & $\begin{array}{l}\text { sim, deixou de } \\
\text { prestar serviços } \\
\text { por causa do riscc }\end{array}$ \\
\hline
\end{tabular}

\begin{tabular}{|c|c|c|c|c|c|c|c|c|c|}
\hline & \multicolumn{9}{|c|}{ BRASIL } \\
\hline Produtor & $B R 1$ & $B R 2$ & $B R 3$ & $B R 4$ & $B R 5$ & $B R 6$ & $B R 7$ & $B R 8$ & $B R 9$ \\
\hline Terceiriza & $\begin{array}{c}\text { sim - laranja } \\
\text { não - grãos }\end{array}$ & sim & não & sim - Iaranja & parcialmente & $\begin{array}{l}\text { sim - cana } \\
\text { não - grãos } \\
\end{array}$ & $\begin{array}{c}\text { sim - silagem } \\
\text { não-grãos }\end{array}$ & parcialmente & parcialmente \\
\hline $\begin{array}{c}\text { Corresponsabilidade } \\
\text { judicial }\end{array}$ & corresponsabilidade & corres ponsabilidade & não & $\begin{array}{l}\text { não para lesão, } \\
\text { corres pons abilidade } \\
\text { para pagamento, } \\
\text { impostos e direitos }\end{array}$ & corres pons abilidade & $\begin{array}{c}\text { não sabe para lesão, } \\
\text { corres ponsabilidade } \\
\text { para pagamento, } \\
\text { impostos e direitos }\end{array}$ & não & \begin{tabular}{|c|} 
não para lesão, \\
corres pons abilidade \\
para pagamento, \\
impostos e direitos
\end{tabular} & não \\
\hline \begin{tabular}{|c|} 
Responsabilizado \\
judicialmente por \\
erro de terceiros \\
prestando serviço na \\
propriedade \\
\end{tabular} & 2 & 2 & 2 & 3 & 3 & 2 & 2 & 1 & 3,5 \\
\hline \begin{tabular}{|c|}
$\begin{array}{c}\text { Já deixou de } \\
\text { contratar por } \\
\text { responsabilidade } \\
\text { judicial }\end{array}$ \\
\end{tabular} & $\operatorname{sim}$ & $\operatorname{sim}$ & $\begin{array}{c}\text { sim, na construção } \\
\text { civil }\end{array}$ & $\operatorname{sim}$ & $\begin{array}{l}\text { nunca pensou a } \\
\text { respeito }\end{array}$ & $\operatorname{sim}$ & $\operatorname{sim}$ & $\operatorname{sim}$ & sim \\
\hline
\end{tabular}

Fonte: elaborado pela autora (2019).

O estudo de caso também permitiu observar que a nova lei contribuiu para muitas das atividades terceirizadas no País, uma vez que dois produtores dos oito entrevistados indicaram que os contratos de terceirização foram iniciados na última safra 2018/2019, após a Lei 13.429, de 2017, ser aprovada.

\subsubsection{Sistema judiciário}

Vários autores examinaram o efeito das instituições e dos sistemas jurídicos sobre o crescimento econômico ou outras medidas de bem-estar humano. (Acemoglu, Johnson, \& Robinson, 2001; Alchian \& Demsetz, 1973; Almeida \& Zylbersztajn, 2012; Azevedo \& Silva, 2007; Bednar, 2004; Borner, Brunetti, \& Weder, 1992; Castelar, 2009; Cooter \& Ulen, 2016; Cross \& Donelson, 2010; Djankov et al., 2002; Haggard \& Tiede, 2011; Hall \& Jones, 1999; La Porta, Lopez-De-Silanes, Shleifer, \& Vishny, 1997; LaPorta et al., 1998; North, 1991; Rezende \& Zylbersztajn, 2012, 2012; Sanches \& Bataglia, 2015; Sztajn \& Zylbersztajn, 2005; Timm, 2009; Wang et al., 2014; Woodruff, 2006).

É sabido que as instituições e o sistema jurídico afetam o ambiente de negócios. Wang et al. (2014) observaram que a baixa qualidade do sistema judiciário tem impactos no 
desenvolvimento econômico de um país, mas também no ambiente microeconômico, o das organizações, onde pode apresentar efeitos adversos. Em seu estudo, eles apontam que busca pela qualidade judiciária gerará, além de impactos na economia, impactos na vantagem comparativa das empresas que utilizam insumos com especificidade de ativos relacionais.

Alchian (1965) enfatiza que o conjunto de regras que garantem a distribuição dos direitos de propriedade determina o nível de produção da empresa porque estabelecem os incentivos de cada indivíduo de produzir.

O sistema judiciário dos dois países do estudo de caso é diferente, assim como os indicadores de governança do ambiente institucional apresentam diferenças consideráveis nos quesitos estabilidade política, eficácia do governo, qualidade regulatória, Estado de Direito e controle da corrupção; também é diferente a origem dos dois sistemas judiciais.

Os resultados na Tabela 19 e na Tabela 20 mostram a diferença de percepção dos agricultores do estudo de caso dos dois países. Índices como a qualidade satisfatória geral do sistema judiciário revelam que os agricultores brasileiros não concordam que o sistema judiciário brasileiro apresenta qualidade satisfatória acima da média, enquanto os norteamericanos concordam que o sistema judiciário norte-americano tem qualidade satisfatória.

Outros índices, como 'custo' e 'burocracia' para utilizar o sistema judiciário foram próximos e abaixo do ponto de neutralidade, mostrando que agricultores dos dois países não consideram todos os atributos de seus sistemas judiciais positivos, acima do ponto de neutralidade.

Tabela 19: Atributos do Sistema judiciário no Brasil e Estados Unidos

\begin{tabular}{|c|c|c|c|c|}
\hline \multirow[b]{2}{*}{ Atributos Sistema Judicial } & \multicolumn{2}{|c|}{ Estados Unidos } & \multicolumn{2}{|c|}{ Brasil } \\
\hline & Resultado médio & Desvio Padrão & Resultado médio & Desvio Padrão \\
\hline $\begin{array}{l}\text { Qualidade judicial satisfatória (tempo, custo, } \\
\text { acesso, previsibilidade, imparcialidade) }\end{array}$ & 3,82 & 1,08 & 2,20 & 1,03 \\
\hline Rapidez/tempo na solução de disputas & 1,91 & 0,70 & 2,80 & 0,92 \\
\hline Custo de utilizar o sistema judicial & 2,09 & 1,30 & 2,10 & 0,74 \\
\hline Burocracia do sistema judicial & 2,09 & 0,83 & 2,40 & 1,35 \\
\hline Acesso ao sistema judicial & 3,64 & 1,29 & 4,10 & 0,99 \\
\hline
\end{tabular}

*escala likert de cinco pontos

Fonte: elaborado pela autora (2018)

North (1992) ressalta que um sistema jurídico relativamente imparcial na execução judicial desempenha um papel importante em coibir problemas de oportunismo e hold up, permitindo, dessa maneira, o desenvolvimento de um sistema de contratação, que é requisito 
essencial para a especialização econômica. Ele considera que as percepções individuais sobre a imparcialidade das regras do jogo obviamente afetam o desempenho das empresas.

Quando se analisa a confiança nos mecanismos de resolução de conflitos nos dois países, encontram-se, nos Estados Unidos, índices de confiança maiores que os resultados brasileiros. Apesar de todos os mecanismos terem índices positivos (acima de 2), os do Brasil se aproximam mais do ponto neutro mostrando, inclusive, que o mecanismo que o povo brasileiro menos confia são os tribunais, com uma média de 2,1 .

Outro ponto que reforça a pouca confiança nos tribunais e juízes no País é a confiança na imparcialidade dos tribunais, que exibe resultados negativos (1,8 de 4), acentuando a falta de confiança que os brasileiros têm, diferente dos agricultores norte-americanos que tem um índice de 2,91.

Tabela 20: Grau de confiança em mecanismos de resolução de disputas no Brasil e Estados Unidos

\begin{tabular}{|c|c|c|c|c|}
\hline \multirow[b]{2}{*}{ Grau de Confiança $^{1}$} & \multicolumn{2}{|c|}{ Estados Unidos } & \multicolumn{2}{|c|}{ Brasil } \\
\hline & Resultado médio & Desvio Padrão & Resultado médio & Desvio Padrão \\
\hline Confiança mediação & 3,09 & 0,54 & 2,20 & 0,63 \\
\hline Confiança arbitragem & 2,55 & 0,69 & 2,30 & 0,67 \\
\hline Confiança tribunais e juízes & 3,00 & 0,89 & 2,10 & 0,57 \\
\hline Confiança na imparcialidade dos tribunais & 2,91 & 0,83 & 1,80 & 0,79 \\
\hline Quanto do tempo confia nos tribunais* & 1,91 & 0,83 & 1,80 & 0,79 \\
\hline
\end{tabular}

${ }^{1}$ : escala likert de 4 pontos

* escala likert de 3 pontos

Fonte: elaborado pela autora (2018)

Um sistema judiciário de qualidade inspira confiança e reduz a incerteza no ambiente de negócios, para que os gestores, agentes e organizações possam se engajar em transações, negociar e contratar.

\subsection{Conclusão}

O propósito de um estudo de caso é investigar qualitativamente um fenômeno que ainda está ocorrendo, as relações entre esse fenômeno e as variáveis que os afetam. Na decisão sobre a estrutura de governança da firma, os gestores decidem se as transações são organizadas dentro da estrutura da empresa, se adquirem no mercado ou se se organizam com terceiros, por meio de contratos. A escolha por desenvolver atividades fora do escopo da firma, com a contratação de terceiros, não é um fenômeno atual, porém, havia no Brasil algumas barreiras à terceirização de serviços, barreiras essas que foram removidas após a Lei 13.429, de 2017. Cabe relembrar que o fenômeno que se estuda neste trabalho é a influência 
do ambiente institucional, na minimização da incerteza no ambiente de negócios, para que as empresas possam escolher a estrutura de governança mais eficientemente, e a nova lei tem efeito importante nesta influência.

Williamson (2000) ressalta que, no ambiente institucional, composto pelas constituições, leis, direitos de propriedade é onde ocorrem as oportunidades para a economia de primeira ordem e que, embora tais escolhas de primeira ordem sejam importantes para a produtividade econômica, as mudanças cumulativas neste nível são muito difíceis de orquestrar. Mudanças nas regras do jogo costumam ocorrer na ordem de décadas e séculos.

Para entender melhor a influência da incerteza no ambiente institucional foi realizada uma análise comparativa entre os Estados Unidos e o Brasil; o primeiro tem reconhecidamente um Estado de Direito e um sistema judiciário de maior qualidade e estabilidade que no Brasil. Nos Estados Unidos, a prática de terceirização é adotada a muito tempo e não há entraves no Estado de Direito, nem existe no sistema judiciário inclinação contra sua adoção, de modo que os empresários encontram maior segurança no ambiente institucional para desintegrar uma atividade de seu escopo. Os estudos de caso evidenciam a percepção positiva em relação à qualidade e à imparcialidade do sistema judiciário norteamericano, características que conferem ao ambiente de negócios menor interferência da incerteza no alinhamento das transações. Os resultados evidenciam também que mecanismos de resolução de disputas alternativos como a mediação e a arbitragem são desenvolvidos e bem conhecidos pelas partes, uma vez que eles conferem a disputas menores maior celeridade de resolução e ajudam a desafogar os tribunais. A existência de seguros de responsabilidade civil e de mecanismos privados de transferência de riscos também atua na redução da incerteza no ambiente de negócios. Uma vez que a prática é consolidada, existem boas opções de empresas de serviços especializadas no mercado.

No Brasil, a terceirização era restrita antes de 2017, por meio da Súmula 331 do Tribunal Superior do Trabalho. Dessa forma, a autorização de forma parcial da terceirização para atividades-meio causava dúvidas no ambiente de negócios quanto à estrutura de governança que legalmente poderia ser adotada, refreando muitas empresas de optar por atividades desintegradas verticalmente. A nova, no entanto, lei tem incentivado os agricultores a se engajarem em novas relações contratuais; dois agricultores no Brasil iniciaram seus contratos na safra 2018/2019.

Somada a essa restrição anterior à terceirização, existe a percepção negativa dos produtores rurais brasileiros sobre a qualidade do sistema judiciário, quando este (sistema judiciário) deveria assegurar às partes o cumprimento imparcial das leis e acordos firmados. 
Em vez de assegurar a minimização da incerteza, o sistema judiciário brasileiro é visto pelos tomadores de decisão como parcial, e ao tentar equilibrar o poder entre as partes, acaba inibindo acordos e transações que beneficiariam o desenvolvimento da economia e do País. No Brasil, o mercado de seguros rurais, como o seguro de responsabilidade civil, não é desenvolvido na área rural, dessa forma, as partes, por temerem problemas judiciais com terceiros, acabam por integrar as atividades; além de que os mecanismos alternativos de resolução de disputas, como a mediação e arbitragem, estão em fase inicial no ambiente brasileiro.

Buscaglia e Ulen (1997) salientam que na ausência de um judiciário imparcial e eficiente ou de mecanismos alternativos de resolução de litígios, as partes privadas tendem a confiar na reputação, nas relações familiares e nas transações recorrentes com agentes de confiança. Situação que ocorre no agronegócio brasileiro quando os produtores rurais decidem desintegrar as atividades. Entretanto, dessa forma muitas transações potencialmente benéficas deixam de acontecer envolvendo partes que não se conhecem previamente ou empresas entrantes no mercado.

Outro importante indicativo da incerteza no ambiente institucional brasileiro é a respeito da responsabilidade judicial caso algum problema com o terceiro venha a ocorrer; no País, o contratante assume a responsabilidade tanto quanto a empresa contratada, que detém o direito de decisão da atividade, o que aumenta o risco de contratar atividades de terceiros. Essas informações corroboram que a incerteza no ambiente institucional brasileiro é maior que o enfrentado no ambiente norte-americano pelos produtores rurais, ao decidirem quais atividades integram dentro de suas fazendas.

Ao comparar a contratação ou não de serviços terceirizados nos dois países, identificase que no Brasil é maior a quantidade de produtores que delegam a execução de atividades a outras partes; no entanto, a terceirização ocorre principalmente em culturas de importância secundária ou para complementar a capacidade de uma atividade integrada verticalmente, ou ainda quando os produtores de laranja terceirizam a colheita porque a estrutura para integrar a atividade seria proibitiva, apresentando, por conseguinte, outras variáveis que possivelmente influenciam a decisão.

No alinhamento das bases (do banco de três pés) que alinham os acordos na arquitetura organizacional (Brickley Smith e Zimmerman, 1995; Sykuta, 2012), além do direito de decisão (integrado ou terceirizado) e da incerteza, está o valor criado na terceirização de atividades, que pode ser criado por meio de baixos custos de transação e 
ganhos de especialização, ou pode ser destruído quando os custos de transação são altos e aumentam as perdas ocorridas em eventuais problemas decorrentes da desintegração.

No Brasil, o índice de valor criado em transações de terceirização é maior que nos Estados Unidos, mostrando que os agricultores brasileiros acreditam que há mais benefícios do que perdas ao desintegrar uma atividade. Um ponto contra a terceirização identificado, que impede ainda que muitos terceirizem atividades no Brasil, é a insuficiência de opções de prestadores profissionalizados, sendo um risco muito alto contratar prestadores de serviços não idôneos e, ainda poder ser responsabilizado por qualquer problema que ele venha a enfrentar.

Tal escassez de empresas de prestação de serviços é justificada pela ainda recente aprovação da nova lei e legalidade na ampla terceirização. Uma vez que não existem muitas empresas prestadoras de serviços especializados e o risco de se engajar e ser coresponsabilizado está previsto na lei, os contratos realizados atualmente são baseados em reputação e relacionamento prévio do contratado pelo contratante, sendo a maioria deles entre produtores rurais. Esta situação é prevista por Buscaglia e Ulen (1997), na falta de um judiciário imparcial e eficiente.

Paralelamente, a comparação ampla de produtores que contratam versus não contratamocorreu também em relação à produção de grãos para minimizar a influência da diversificação de culturas no Brasil, bem como reduzir o impacto de particularidades de cada cultura. O resultado é que os Estados Unidos apresentam maior quantidade de produtores que contratam atividades em grãos, o que corrobora com a constatação de que, em atividades com especificidades semelhantes, a desintegração de atividades mediante contratos em ambiente institucional com menor incerteza é maior. Porém, observa-se que a especificidade temporal é diferente nos dois países e ela também apresenta influência nessa decisão: como o Brasil possui clima favorável, a produção agrícola de grãos ocorre o ano todo, os produtores rurais brasileiros realizam duas safras no mesmo ano; assim, algumas atividades apresentam uma janela de tempo pequena para ocorrer antes de a próxima safra começar, diferente dos Estados Unidos, que produz uma vez ao ano.

A incerteza é atributo importante no alinhamento das transações dentro da firma ou fora dela e sua importância é destacada, tanto na Teoria dos Custos de Transação, quanto na Arquitetura Organizacional dos acordos. Mediante os estudos de caso, pode-se, portanto, demonstrar que a incerteza proveniente do ambiente institucional é fator importante na escolha das estruturas de governança das empresas do agronegócio. 
Além da incerteza existe também importante atuação do valor criado na alocação dos direitos de decisão e estruturas de governança escolhidas; a relação do valor criado com a alocação dos direitos de decisão também pode ser observada tanto nos casos brasileiros quanto nos norte-americanos.

Todavia, não é possível inferir se a relação é significativa ou qual a magnitude da influencia de cada uma delas na decisão de contratar um serviço ou integrar verticalmente uma atividade. Cabe ressaltar que o estudo de casos traz algumas informações quantitativas apenas para dar suporte ao estudo qualitativo, este estudo não tem o intuito de fazer inferências com tais resultados, provenientes de uma amostra muito pequena para este fim. 


\section{CONSIDERAÇÕES FINAIS}

A presente tese foi motivada pelos processos judiciais contra empresas que terceirizavam atividades e pela interferência do sistema judiciário na escolha da forma como a empresa estruturava as transações dentro ou fora da firma. A questão de pesquisa que surgiu no desenvolvimento da tese é se a incerteza, presente no ambiente institucional, resultante do sistema judiciário, influencia a escolha das estruturas de governança das empresas do agronegócio; uma vez que o ambiente institucional e as instituições são importantes e moldam a estrutura de incentivos no ambiente organizacional, uma vez que os custos de transação determinantes da estrutura de governança das organizações são influenciados diretamente pelo ambiente institucional em que elas estão inseridas.

Tais incentivos podem motivar ou desmotivar os gestores a realizarem investimentos nas empresas, assim como também podem oferecer segurança para as empresas se engajarem em acordos e transações ou, por outro lado, podem aumentar a incerteza e desencorajar os gestores a se engajarem em relacionamentos ou realizarem investimentos.

A ideia central é que o gestor, ao decidir se uma transação é realizada internamente ou por meio de um contrato, se defronte com uma situação na qual as variáveis se equilibrem como em um banco de três pernas, como sugerido pela Arquiterura Organizacional dos Acordos - e o valor criado, o direito de decisão e a incerteza se balanceiem entre si. O valor criado é decorrente dos benefícios que os produtores exergam na opção pela terceirização, bem como os custos, como os de transação, que a desintegração vertical pode ocasionar. $\mathrm{O}$ direito de decisão é a opção de quem executa e decide aspectos a respeito da atividade, se um gestor interno ou uma empresa especializada. Por fim, tem-se a incerteza, que é o ponto principal analisado na tese, e que é influenciada pelo ambiente institucional e o sistema judiciário do país. Além de explicar a existência da firma, Coase (1960) aponta que os custos de transação também explicam a existência das leis.

De modo geral, os aspectos condutores da discussão sobre o ambiente institucional e a incerteza são dois: primeiro, a questão do Estado de Direito e as leis que impõe restrições ao gestor, como o caso do Brasil em que a Súmula 331 do TST impedia que as empresas terceirizassem atividades-fim antes de 2017, o que impactava diretamente na decisão sobre a estrutura de governança; em segundo lugar, tem-se a questão do grau de incerteza no ambiente institucional, que eleva os custos de transação e favorece a integração vertical, ao diminuir o valor gerado nas transações realizadas fora da firma. 
Baseada na problemática acima, a pesquisa desenvolve uma abordagem para a análise do Estado de Direito e do sistema judiciário e de sua influência na estrutura de governança das empresas. Parte-se da ideia que a estratégia da firma não se baseia somente no valor criado pela transação, mas que também a incerteza causada pelo ambiente institucional influencia na tomada de decisão. Apesar de a incerteza fazer parte do arcabouço teórico da teoria dos custos de transação e da arquitetura organizacional, ela costuma ser deixada em segundo plano em pesquisas anteriores sobre as estruturas de governança das empresas, além de ser considerada de forma ampla e proveniente de fontes diversas. Esta pesquisa, pois, teve o intuito de analisar a incerteza proveniente de características e do desempenho do sistema judiciário existente e operante nos países.

A tese inicia-se com uma investigação teórica sobre as estruturas de governança e modelos de alinhamento das transações, como a teoria dos custos de transação de Williamson (1979, 1985, 1991, 1993, 1996, 1998, 2000) e da arquitetura dos acordos de Sykuta (2012), adaptado da arquitetura organizacional de Brickley Smith e Zimmerman (1995). Prosseguese, então, para uma investigação teórica sobre o ambiente institucional, o importante papel que cumpre no desenvolvimento de uma nação e sobre sua influência no desempenho das empresas. O enfoque da pesquisa no ambiente institucional é no Estado de Direito, nas leis e no sistema judiciário. O ponto de convergência dos dois arcabouços teóricos é a incerteza, variável explicativa nos dois modelos de estrutura de governança no alinhamento das transações; a qual tem sua dimensão afetada pela eficiência e pela atuação das instituições.

A segunda parte da pesquisa busca evidências empíricas que dê suporte à relação proposta da incerteza do sistema judiciário, afetando as estruturas de governança; para tanto, são analisados dois países com sistemas judiciais distintos: o sistema judiciário brasileiro, com origem na civil law, e o sistema judiciário norte-americano, derivado da common law. Em cada um desses ambientes institucionais foram desenvolvidos estudos de caso em propriedades rurais para análise estrutural discreta da governança no alinhamento entre valor criado, direito de decisão e incerteza. Como resultado da análise dos estudos de caso, a relação entre as variáveis foi verificada no alinhamento das transações e acordos, contudo, a magnitude e a significância dessas relações não podem ser mensuradas em metodologias qualitativas, consistindo esta na primeira limitação da presente pesquisa.

Essa tese, a partir da revisão de literatura e da análise do trabalho empírico de campo, traz algumas contribuições para o conhecimento na área de estratégia de empresas e nova economia institucional. O principal deles é a análise da escolha estratégica da estrutura de 
governança das empresas sob o enfoque das características e desempenho do sistema judiciário e da incerteza proveniente deste.

A tese ainda traz contribuições gerenciais ao compilar de fatores que criam valor em transações de terceirização, os quais podem ajudar os executivos, gestores e produtores rurais na tomada de decisão, podendo ser utilizada, também, para conscientizar os executivos sobre os principais entraves enfrentados na gestão de contratos com terceiros, bem como esclarece a corresponsabilidade judicial para os produtores rurais brasileiros que pretendem terceirizar atividades.

Existem também contribuições e incentivos à criação de políticas públicas relacionadas ao sistema judicial, uma vez que ele está relacionado ao desenvolvimento da economia. Políticas públicas nesse setor beneficiariam não somente o desempenho das empresas, como também toda a população.

Esta tese possui algumas limitações, inerentes a toda pesquisa, dentre as quais é possível destacar a limitação do número de casos estudados não ser suficiente para realizar inferências sobre o impacto e sobre a magnitude das variáveis no alinhamento das transações na estrutura de governança empresarial, bem como acerca da significância da relação entre as variáveis. Outra limitação está presente na diversidade das transações estudadas conjuntamente, uma vez que cada uma delas tem características e especificidades diferentes.

A revisão de literatura realizada nesta pesquisa pode não ter contemplado e coberto toda a literatura existente sobre o tema, uma vez que a literatura sobre estratégia é extensa e diversificada. Ainda com relação à revisão de literatura, o tema da economia e do direito que trata os sistemas judiciais e sua influência nas empresas é escasso, conforme descrito na revisão sistêmica.

Ainda existe a limitador da interpretação e percepção da pesquisadora. Apesar de diversos produtores rurais terem sido entrevistados, a percepção e a interpretação da pesquisadora em um estudo qualitativo podem afetar os resultados da pesquisa

A presente pesquisa também incita uma grande quantidade de questões, a pesquisa diz pouco a respeito de mecanismos alternativos de resolução de disputas que não os sistemas judiciais tradicionais, como tribunais e cortes que, por vezes, podem apresentar maior eficiência e, desse modo, contribuir para a redução da incerteza do ambiente institucional.

Conforme indicado no capítulo 3 , a busca por eficiência no alinhamento das transações leva em conta diversos fatores, particularmente a incerteza e o valor criado, sendo que este último, o valor criado nos acordos com terceiros, foi superficialmente investigado, havendo fortes razões para aprofundar uma investigação conjunta desses temas. 
Como sugestão de pesquisas futuras sobre o tema cabe: (i) aprofundar mais a revisão de literatura sobre a influência do ambiente institucional nas empresas, buscando sempre novos estudos e estudos de vanguarda; (ii) desenvolver um modelo econométrico para capturar a relação entre as variáveis discutidas nesta tese; (iii) ampliar os estudos de caso em outros países para verificar a validade dos achados; (iv) estender o estudo para outros setores produtivos. 


\section{REFERÊNCIAS 9}

Acemoglu, D., Johnson, S., \& Robinson, J. A. (2001). The Colonial Origins of Comparative Development: An Empirical Investigation. The American Economic Review, 91(5), 13691401.

Alchian, A. A. (1965). SOME ECONOMICS OF PROPERTY RIGHTS. Il Politico, 30(4), 816-829.

Alchian, A. A., \& Demsetz, H. (1973). The Property Right Paradigm. The Journal of Economic History, 33(1,), 16-27.

Allen, D. W. (2000). Transaction Costs. In Encyclopedia of Law and Economics (Vol. 1). Recuperado de http://ecsocman.hse.ru/data/008/450/1217/0740book.pdf

Almeida, L. F. de, \& Zylbersztajn, D. (2012). Análise comparada entre o mercado de crédito agrícola no Brasil e nos Estados Unidos. Organizações Rurais \& Agroindustriais, 14(1). Recuperado de http://repositorio.ufla.br/jspui/handle/1/8933

Andrade, R. P. de. (2011). A construção do conceito de incerteza: uma comparação das contribuições de Knight, Keynes, Shackle e Davidson. Nova Economia, 21(2), 171-195. https://doi.org/10.1590/S0103-63512011000200001

Azevedo, P. F., \& Silva, V. L. S. (2007). Governance Inseparability in Franchising: Multi-case Study in France and Brazil. In Economics and Management of Networks (p. 97-115). Economics and Management of Networks.

Bansal, P. T., \& Corley, K. (2012). What's Different about Qualitative Research? Academy of Management Journal, 55(3), 509-513. https://doi.org/10.5465/amj.2012.4003

Bardin, L. (2008). Análise de conteúdo. 5. ed. Lisboa: Edições 70.

Bednar, J. (2004). Judicial Predictability and Federal Stability: Strategic Consequences of Institutional Imperfection. Journal of Theoretical Politics, 16(4), 423-446. https://doi.org/10.1177/0951629804046149

Besanko, D., Dranove, D., Shanley, M., \& Schaefer, S. (2012). A Economia da Estratégia (5o ed). Porto Alegre: Bookman Editora.

BÍBLIA, Português. A Bíblia Sagrada: Antigo e Novo Testamento. Tradução de João Ferreira de Almeida. Edição rev. e atualizada no Brasil. Edição on line. Recuperado de: https://www.bibliaonline.com.br/acf/hb/11

Bolton, P., \& Dewatripont, M. (2005). Contract Theory. MIT Press.

Bonoma, T. V. (1985). Case Research in Marketing: Opportunities, Problems, and a Process. Journal of Marketing Research, 22(2), 199-208. https://doi.org/10.1177/002224378502200209

Borner, S., Brunetti, A., \& Weder, B. (1992). Institutional obstacles to Latin American growth. San Francisco, Calif: ICS Press.

Brasil. Art. 421 do Código Civil, Pub. L. No. Lei 10406/02 (2002).

Brasil. Lei $N^{o}$ 13.129, de 26 de maio de 2015 (2015, 26 de maio). Altera a Lei $\mathrm{n}^{\circ}$ 9.307, de 23 de setembro de 1996, e a Lei $\mathrm{n}^{\circ}$ 6.404, de 15 de dezembro de 1976, para ampliar o âmbito de aplicação da arbitragem e dispor sobre a escolha dos árbitros quando as partes recorrem a órgão arbitral, a interrupção da prescrição pela instituição da arbitragem, a concessão de tutelas cautelares e de urgência nos casos de arbitragem, a carta arbitral e a sentença arbitral, e

\footnotetext{
${ }^{9}$ De acordo com o estilo APA (American Psychological Association)
} 
revoga dispositivos da Lei $\mathrm{n}^{\circ}$ 9.307, de 23 de setembro de 1996. Recuperado de: http://www.planalto.gov.br/ccivil_03/_Ato2015-2018/2015/Lei/L13129.htm

Brasil. Lei $N^{o}$ 13.429, de 31 de março de 2017. (2017, 31 de março). Altera dispositivos da Lei n o 6.019 , de 3 de janeiro de 1974, que dispõe sobre o trabalho temporário nas empresas urbanas e dá outras providências; e dispõe sobre as relações de trabalho na empresa de prestação de serviços a terceiros. Recuperado de: http://www.planalto.gov.br/ccivil_03/_Ato20152018/2017/Lei/L13429.htm

Brickley, J. A., Smith, C. W., \& Zimmerman, J. L. (2007). Managerial economics and organizational architecture. Boston: McGraw-Hill Irwin.

Brickley, J., Smith, C. W., \& Zimmerman, J. L. (1995). The economics of organizational architecture. Journal of Applied Corporate Finance, 19-31.

Brunetti, A., \& Weder, B. (1994). Political credibility and economic growth in less developed countries. Constitutional Political Economy, 5(1), 23-43. https://doi.org/10.1007/BF02393254

Burnard, P., Gill, P., Stewart, K., Treasure, E., \& Chadwick, B. (2008). Analysing and presenting qualitative data. British Dental Journal, 204(8), 429-432.

Buscaglia, E., \& Ulen, T. (1997). A quantitative assessment of the efficiency of the judicial sector in Latin America. International Review of Law and Economics, 17(2), 275-291. https://doi.org/10.1016/S0144-8188(97)00007-0

Campomar, M. C. (2011). Marketing de verdade: uma forma eficaz de usar o marketing a seu favor e aumentar seus resultados. São Paulo: Gente.

Castelar, A. (2009). Judiciário e economia no Brasil. https://doi.org/10.7476/9788579820199

Centro de Estudos Avançados em Economia Aplicada. (2018). PIB do Agronegócio Brasileiro. Recuperado de CEPEA website: https://www.cepea.esalq.usp.br/br/pib-do-agronegociobrasileiro.aspx

Cheung, S. N. S. (1983). The Contractual Nature of the Firm. The Journal of Law \& Economics, 26(1), 22.

Coase, R. (1937). The Nature of the Firm. Economica, 4(16), 386. https://doi.org/10.2307/2626876

Coase, R. (1960). The Problem of Social Cost. Journal of Law and Economics, 1-44.

Coase, R. (1987). The Firm, the Market, and the Law. Recuperado de https://www.press.uchicago.edu/ucp/books/book/chicago/F/bo5954330.html

Coase, R. (1991). The Institutional Structure of Production. The American Economic Review, 82(4), 713-719.

Coase, R. (1998). The New Institutional Economics. The American Economic Review, 88(2,), 72-74.

Conselho Superior da Magistratura. Provimento no 2.348 (2016).

Cooter, R., \& Ulen, T. (2016). Law and Economics (6th ed). Recuperado de https://scholarship.law.berkeley.edu/cgi/viewcontent.cgi?article=1001\&context=books

Creswell, J. W. (2007). Qualitative Inquiry and Research Design: Choosing Among Five Approaches (2nd ed). Recuperado de http://journals.sagepub.com/doi/10.1177/1524839915580941

Cross, F. B., \& Donelson, D. C. (2010). Creating Quality Courts: Creating Quality Courts. Journal of Empirical Legal Studies, 7(3), 490-510. https://doi.org/10.1111/j.1740-1461.2010.01186.x

CUT. (2017). Terceirização: salários piores, acidentes e menos direitos. Recuperado 6 de março de 2019, de CUT - Central Única dos Trabalhadores website: https://www.cut.org.br/noticias/efeitos-da-terceirizacao-salarios-mais-baixos-mais-acidentese-menos-direitos-5cb1 
De Massis, A., \& Kotlar, J. (2014). The case study method in family business research: Guidelines for qualitative scholarship. Journal of Family Business Strategy, 5(1), 15-29.

Demsetz, H. (1967). Toward a Theory of Property Rights. The American Economic Review, 57(2,), 347-359.

Djankov, S., LaPorta, R., Lopez-de-Silanes, F., \& Shleifer, A. (2002). The Regulation of Entry. Quarterly Journal of Economics, 117(1), 1-37.

Eisenhardt, K. M. (1989). Building Theories from Case Study Research. The Academy of Management Review, 14(4), 532-550. https://doi.org/10.2307/258557

Farina, E. M. M. Q. (1999). Competitividade e coordenação de sistemas agroindustriais: um ensaio conceitual. Gestão \& Produção, 6(3), 147-161. https://doi.org/10.1590/S0104$530 X 1999000300002$

Farina, E. M. M. Q., Saes, M. S. M., \& Azevedo, P. F. (1997). Competitividade: mercado, estado e organizações. São Paulo: Singular.

Food and Agriculture Organization of the United Nations. (2018). FAOSTAT. Recuperado de http://www.fao.org/faostat/en/\#data/TP

Gil, A. C. (2008). Métodos e Técnicas de Pesquisa Social (6o ed). Grupo GEN.

Haggard, S., \& Tiede, L. (2011). The Rule of Law and Economic Growth: Where are We? World Development, 39(5), 673-685. https://doi.org/10.1016/j.worlddev.2010.10.007

Hair Jr, J. F., Babin, B., Money, A. H., \& Money, A. H. (2005). Fundamentos de Métodos de Pesquisa em Administração (Edição: 1a). Porto Alegre: Bookman.

Hall, R. E., \& Jones, C. I. (1999). Why Do Some Countries Produce So Much More Output Per Worker Than Others? The Quarterly Journal of Economics, 114(1), 83-116.

Hoppe, R. A., \& MacDonald, J. M. (2013). Updating the ERS Farm Typology. Recuperado 17 de março de 2019, de http://www.ers.usda.gov/publications/pub-details/?pubid=43744

Instituto Brasileiro de Geografia e Estatística. (2017). Censo Agropecuário 2017. Recuperado de IBGE website: https://censoagro2017.ibge.gov.br//

Instituto Nacional de Colonização e Reforma Agrária. (2018). Tabela com módulo fiscal dos municípios. Recuperado 5 de maio de 2019, de http://www.incra.gov.br/tabela-modulo-fiscal

Kaufmann, D., \& Kraay, A. (2019). Worldwide Governance Indicators. Recuperado de World Bank website: http://info.worldbank.org/governance/wgi/\#home

Kaufmann, D., Kraay, A., \& Mastruzzi, M. (2010). The Worldwide Governance Indicators: Methodology and Analytical Issues. World Bank Policy Research, (5430), 31.

Kim, J. J. (2007, agosto 6). Contract [Cornell Law School]. Recuperado 6 de dezembro de 2018, de LII / Legal Information Institute website: https://www.law.cornell.edu/wex/contract

Kremic, T., Rom, W. O., \& Icmeli Tukel, O. (2006). Outsourcing decision support: a survey of benefits, risks, and decision factors. Supply Chain Management: An International Journal, 11(6), 467-482. https://doi.org/10.1108/13598540610703864

La Porta, R. (1996). Expectations and the Cross-Section of Stock Returns. The Journal of Finance, 51(5), 1715-1742.

La Porta, R., Lopez-De-Silanes, F., Shleifer, A., \& Vishny, R. W. (1997). Legal Determinants of External Finance. The Journal of Finance, 52(3), 1131-1150. https://doi.org/10.1111/j.15406261.1997.tb02727.x

Lakatos, E. M., \& Marconi, M. de A. (2003). Fundamentos de metodologia científica. São Paulo: Atlas. 
LaPorta, R., Lopez-de-Silanes, F., Shleifer, A., \& Vishny, R. W. (1998). Law and Finance. Journal of Political Economy, 43.

Lazzarini, S. (2014). Terceirizar atividade-fim: é eficiente limitar? - Economia. Estado de São Paulo. Recuperado de https://economia.estadao.com.br/noticias/geral,terceirizar-atividade-fim-eeficiente-limitar-imp-, 1535960

Leeson, P. T., \& Suarez, P. A. (2016). An economic analysis of Magna Carta. International Review of Law and Economics, 47, 40-46. https://doi.org/10.1016/j.irle.2016.05.001

Lima, T. C. S. de, \& Mioto, R. C. T. (2007). Procedimentos metodológicos na construção do conhecimento científico: a pesquisa bibliográfica. Revista Katálysis, 10(spe), 37-45. https://doi.org/10.1590/S1414-49802007000300004

Litvin, M. (2009, setembro 15). Mutual Assent. Recuperado 6 de março de 2019, de LII / Legal Information Institute website: https://www.law.cornell.edu/wex/mutual_assent

Macneil, I. R. (1978). Contracts: Adjustment of Long-Term Economic Relations under Classical, Neoclassical, and Relational Contract Law. Northwestern University Law Review, 72, 854.

Marconi, M. de A., \& Lakatos, E. M. (2007). Tecnicas de Pesquisa. São Paulo: Atlas.

Martinez, J. S. (2003). Towards an International Judicial System. Stanford Law Review, 56, 429-530.

Mascarin, A. L. C. (2014). Serviços de mecanização agrícola: atividade meio ou atividade fim? (Text, Universidade de São Paulo). https://doi.org/10.11606/D.12.2014.tde-08012015-150454

Mascarin, L. S. (2006). Caracterização de sistemas de colheita e desenvolvimento de técnica para a obtenção de mapas de produtividade para citros (Text, Universidade de São Paulo). https://doi.org/10.11606/D.11.2006.tde-20092006-152503

Matthews, R. C. O. (1986). The Economics of Institutions and the Sources of Growth. The Economic Journal, 96(384), 903-918. https://doi.org/10.2307/2233164

Ministério da Agricultura, Pecuária e Abastecimento. (2018). MAPA Indicadores. Recuperado de MAPA website: http://indicadores.agricultura.gov.br/index.htm

Missouri Department of Agriculture. Missouri Pesticide Use Act. , (1974).

Missouri Economic Research and Information Center. (2016). Economic Contribution of Agribusiness in Missouri (p. 11). Recuperado de Missouri Department of Economic Development website: https://www.missourieconomy.org/pdfs/agribusiness_economic_contribution.pdf

Moher, D., Liberati, A., Tetzlaff, J., \& Altman, D. G. (2009). Preferred Reporting Items for Systematic Reviews and Meta-Analyses: The PRISMA Statement. PLOS Medicine, 6(7), e1000097. https://doi.org/10.1371/journal.pmed.1000097

National Agricultural Statistics Service. (2018). USDA/NASS 2018 State Agriculture Overview for Missouri. Recuperado de United States Department of Agriculture website: https://www.nass.usda.gov/Quick_Stats/Ag_Overview/stateOverview.php?state=MISSOURI

Neves, J. L. (1996). PESQUISA QUALITATIVA - CARACTERÍSTICAS, USOS E POSSIBILIDADES. Caderno de Pesquisas em Administração, 1(1), 5.

Neves, M. F. (2007). Agronegócios e Desenvolvimento Sustentável (1o ed). Recuperado de $\mathrm{http} / / / \mathrm{www}$.favaneves.org/livro-agronegocios-desenvolvimento-sustentavel-fava-neveseditora-atlas-2007/

Neves, M. F. (2008). Método para planejamento e gestão estratégica de sistemas agroindustriais (GESis). RAUSP São Paulo, (4), 13.

North, D. C. (1981). Structure and Change in Economic History (unknown edition). New York London: Norton. 
North, D. C. (1991). Institutions. Journal of Economic Perspectives, 5(1), 97-112. https://doi.org/10.1257/jep.5.1.97

North, D. C. (1992). Transaction costs, institutions, and economic performance. San Francisco, California: ICS Press.

North, D. C. (1994). Economic Performance Through Time. The American Economic Review, 84(3), 11.

North, D. C. (1999). Dealing with a Non-Ergodic World: Institutional Economics, Property Rights, and the Global Environment. Duke Environmental Law \& Policy Forum, 10(1), 12.

North, D. C. (2005). Understanding the Process of Economic Change. Recuperado de https://press.princeton.edu/titles/7943.html

Oliveira, M. M. (2016). Como fazer Pesquisa Qualitativa (7o ed). Recuperado de https://www.travessa.com.br/como-fazer-pesquisa-qualitativa-7-ed-2016/artigo/f2341cf74611-4da6-a17c-5988834e8b58

Osorio, R. M. L., Lima, S. M. V., Sant'anna, R. L., \& Castro, A. M. G. de. (2017). DEMANDAS TECNOLÓGICAS DA CADEIA PRODUTIVA DE LARANJA NO BRASIL. Latin American Journal of Business Management, 8(2). Recuperado de https://ajbm.net/index.php/journal/article/view/425

PL 4330/2004. , (2004).

Porter, M. (2001). The Value Chain and The Competitive Advantage. In Understanding Business: Processes (p. 50-66). Psychology Press.

Pratt, M. G. (2009). For the Lack of a Boilerplate: Tips on Writing Up (and Reviewing) Qualitative Research. Academy of Management Journal, 52(5), 856-862.

Ramello, G. B., \& Voigt, S. (2012). The economics of efficiency and the judicial system. International Review of Law and Economics, 32(1), 1-2. https://doi.org/10.1016/j.irle.2011.12.003

Ramos, D. M. D. O. (2001). Terceirização na Administração Pública. Recuperado de http://www.ltreditora.com.br/e-book-terceirizac-o-na-administrac-o-publica-2246-8.html

Rezende, C. L., \& Zylbersztajn, D. (2012). Pacta sunt servanda versus the social role of contracts: the case of Brazilian agriculture contracts. Revista de Economia e Sociologia Rural, 50(2), 207221. https://doi.org/10.1590/S0103-20032012000200001

Richardson, R. J. (2017). Pesquisa social: Métodos e técnicas (Edição: 4a). Atlas.

Rodas, S. (2018). Número de arbitragens no Brasil aumenta em 2017, mas valores em disputa caem. Recuperado 10 de maio de 2019, de Consultor Jurídico website: https://www.conjur.com.br/2018-mar-04/numero-arbitragens-brasil-aumenta-valores-caem

Sanches, J. Y. L., \& Bataglia, W. (2015). THE LEGAL INSTITUTIONAL ENVIRONMENT IN BRAZIL AND THE COLLECTIVE AND PRIVATE GUARANTEE MECHANISMS FOR ECONOMIC TRANSACTIONS. 23. University of Rio de Janeiro.

Saona, P., \& San Martín, P. (2016). Country level governance variables and ownership concentration as determinants of firm value in Latin America. International Review of Law and Economics, 47, 84-95. https://doi.org/10.1016/j.irle.2016.06.004

Selltiz, C., Wrightsman, L., Cook, S., \& Kidder, L. (1975). Métodos de pesquisa nas relações sociais (6o ed). São Paulo: Editora USP.

Senesi, S., Chaddad, F. R., \& Palau, H. (2013). Networks in Argentine agriculture: a multiple-case study approach. Revista de Administração, 48(2), 281-294. https://doi.org/10.5700/rausp1088

Sherwood, R. M., Shepherd, G., \& De Souza, C. M. (1994). Judicial systems and economic performance. The Quarterly Review of Economics and Finance, 34, 101-116. https://doi.org/10.1016/1062-9769(94)90038-8 
Stanton, B. F. (1978). Perspective on Farm Size. American Journal of Agricultural Economics, 60(5), 727-737. https://doi.org/10.2307/1240082

Supremo Tribunal Federal. (2018). STF decide que é lícita a terceirização em todas as atividades empresariais. Recuperado 6 de março de 2019, de Supremo Tribunal Federal - Noticias STF website: http://www.stf.jus.br/portal/cms/verNoticiaDetalhe.asp?idConteudo=388429

Syam, P. (2014). What is the Difference Between Common Law and Civil Law? [Blog]. Recuperado 20 de fevereiro de 2019, de Washington University in St. Louis website: https://onlinelaw.wustl.edu/blog/common-law-vs-civil-law/

Sykuta, M. E. (2012). THE NATURE OF THE DEAL IN THE POST-CRISIS FINANCIAL MARKET. $7,18$.

Sztajn, R., \& Zylbersztajn, D. (2005). DIREITO E ECONOMIA: ANALISE ECONOMICA DO DIREITO E DAS ORGANIZAÇOES. Recuperado de https://www.travessa.com.br/direito-eeconomia-analise-economica-do-direito-e-das-organizacoes/artigo/350cc5cc-9397-41 f8-924b$83 \mathrm{e} 03 \mathrm{e} 5$ fae $5 \mathrm{c}$

Timm, L. B. (2009). Ainda sobre a Função Social do Direito Contratual no Código Civil brasileiro: justiça distributiva versus eficiência econômica. Revista da AMDE, 2(0). Recuperado de http://www.revista.amde.org.br/index.php/ramde/article/view/26

Tribunal de Justiça do Estado do Rio Grande do Sul. Apelação Cível 70011925617. , (14 de dezembro de 2005).

Tribunal de Justiça do RS. Apelação Cível 70011602091 (Tribunal de Justiça do RS 14 de junho de 2005).

Tribunal Superior do Trabalho. Sumula 331 (2011).

United States Department of Agriculture. (2012). Census of Agriculture. Recuperado de National Agricultural Statistics Service website: https://www.nass.usda.gov/Publications/AgCensus/2012/

United States Department of Agriculture. (2017). Census of Agriculture. Recuperado de National Agricultural Statistics Service website: https://www.nass.usda.gov/Publications/AgCensus/2017/Full_Report/Census_by_State/Misso uri/index.php

United States Department of Agriculture. (2018). Farm Structure. Recuperado 17 de março de 2019, de USDA website: https://www.ers.usda.gov/topics/farm-economy/farm-structure-andorganization/farm-structure/

USDA. (2018). Agricultural Trade. Recuperado de https://www.ers.usda.gov/data-products/ag-andfood-statistics-charting-the-essentials/agricultural-trade/

Vilella, F., Senesi, S., Dulce, E., \& Daziano, M. (2010). The Soybean System in Argentina. A story os sucess. Apresentado em VII International PENSA Conference, São Paulo.

Voss, C., Tsikriktsis, N., \& Frohlich, M. (2002). Case research in operations management. International Journal of Operations \& Production Management, 22(2), 195-219. https://doi.org/10.1108/01443570210414329

Wang, Y., Wang, Y., \& Li, K. (2014). Judicial quality, contract intensity and exports: Firm-level evidence. China Economic Review, 31, 32-42. https://doi.org/10.1016/j.chieco.2014.08.002

Williamson, O. E. (1979). Transaction-Cost Economics: The Governance of Contractual Relations. Journal of Law and Economics, 22(2), 233-261.

Williamson, O. E. (1985). The economics of institutions of capitalism: firms markets, relational contracting. New York: The Free Press. 
Williamson, O. E. (1991a). Comparative Economic Organization: The Analysis of Discrete Structural Alternatives. Administrative Science Quarterly, 36(2), 269. https://doi.org/10.2307/2393356

Williamson, O. E. (1991b). Strategizing, economizing, and economic organization. Strategic Management Journal, 12(S2), 75-94.

Williamson, O. E. (1993). Calculativeness, Trust, and Economic Organization. The Journal of Law and Economics, 36(1, Part 2), 453-486. https://doi.org/10.1086/467284

Williamson, O. E. (1996). The Mechanisms of Governance. Oxford University Press.

Williamson, O. E. (2000). The New Institutional Economics: Taking Stock, Looking Ahead. Journal of Economic Literature, 38(3), 595-613.

Woodruff, C. (2006). Measuring Institutions. Recuperado de https://www.elgaronline.com/view/1845422422.00009.xml

World Bank. (2008). Doing Business in China 2008 (No 74686; p. 1-90). Recuperado de The World Bank website: http://documents.worldbank.org/curated/en/783261468020349761/DoingBusiness-in-China-2008

Yin, R. K. (2010). Estudo de Caso. Bookman Editora.

Zylbersztajn, D. (2005). Papel dos contratos na coordenação agro-industrial: um olhar além dos mercados. Revista de Economia e Sociologia Rural, 43(3), 385-420. https://doi.org/10.1590/S0103-20032005000300001 


\section{APÊNDICES}

APÊNDICE 1 - Protocolo de Estudo de Caso

\section{Introdução ao estudo de caso e objetivo do protocolo}

a. Este trabalho tem como principal objetivo analisar como a incerteza no ambiente institucional impactam nas organizações e influenciam na estrutura de governança adotada por elas.

b. Esse objetivo desdobra-se no estudo de transações dentro de propriedades rurais em dois contextos: Brasil e Estados Unidos.

c. A estrutura teórica para o estudo está apresentada nos capítulos 3 e 4, desta tese.

\section{Procedimento de coleta de dados}

a. Nomes dos locais a serem visitados:

i. Propriedade rural BR1, BR2, BR3, BR4, BR5, BR6, BR7, BR8 e BR9

ii. Prestador de Serviços BRService1

iii. Propriedade rural US1, US2, US3, US4, US5, US6, US7 e US8

iv. Prestador de Serviços USService 1 e USService2.

\section{b. Pessoas a serem entrevistadas nas empresas}

i. Entrevistar o produtor rural ou o gestor responsável pela tomada de decisões a respeito das atividades da propriedade. Se for o caso pode-se entrevistar mais de um produtor rural por caso, realizando a entrevista individualmente ou em conjunto.

ii. Deve-se ressaltar que a unidade de análise é a propriedade rural e as transações que ocorrem na produção agrícola.

iii. Nas empresas prestadoras de serviços entrevistar o gestor com conhecimento sobre as atividades de prestação de serviços e da responsabilidade judicial das atividades prestadas.

\section{c. Procedimento de contato e comunicação com os produtores rurais}

i. Primeiro contato: fazer contato por e-mail ou telefone com o produtor rural selecionado buscando verificar o seu interesse em participar do estudo de caso. Ao demonstrar o interesse formalizar o convite e pré-agendar a entrevista.

ii. E-mail convite: enviar e-mail formalizando a participação da propriedade rural no estudo. iii. Agendamento das entrevistas: 
1. As entrevistas devem ser preferencialmente feitas pessoalmente para haver maior riqueza na coleta de dados.

2. Verificar local de preferência para o produtor: fazenda, na universidade ou algum outro local de preferência. Ou quando não for possível participar por Skype ou telefone.

3. Enviar o formulário de consentimento de participação na pesquisa e coleta de dados.

\section{d. Procedimento de coleta dos dados nas empresas selecionadas}

i. Agendamento das entrevistas: agendada a data, enviar e-mail/ligar 48 horas antes da data da visita.

ii. Enviar roteiro das entrevistas (APÊNDICES 2 e 3): enviar antecipadamente o roteiro das entrevistas para que o entrevistado possa preparar-se.

iii. Realizar as entrevistas por meio do roteiro semiestruturado desenvolvido

- Gravar as entrevistas (pedir autorização) e tomar notas para posterior transcrição, gerando documentação para análise.

- Apresentar após a entrevista os objetivos da pesquisa para não enviesar as respostas dos respondentes

- Verificar a possibilidade de coletar evidências que confirmem o que foi relatado pelo entrevistado, bem como realização de observações.

- Agradecer o entrevistado e a empresa pela oportunidade de realizar o trabalho.

iv. Enviar a versão final digital da tese para os participantes junto com carta de agradecimento pela participação (APÊNDICE 4).

\section{Esboço do relatório do estudo de caso}

a. Conforme a metodologia de análise de conteúdo, foi realizada a transcrição literal das entrevistas. Após isso, seguiram-se os passos propostos na metodologia do trabalho para análise dos resultados. 
APÊNDICE 2 - Intrumento de coleta de dados em Português

\section{Roteiro da entrevista em Português}

\section{EMPRESA}

Neste bloco de questões as principais características da empresa e da propriedade rural serão analisadas para comparar casos múltiplos. Bem como uma particularidade da empresa pode afetar a estratégia da empresa e os resultados.

\section{Histórico da Empresa}

Como começou; o que motivou a empresa a entrar no setor do agronegócio, há quanto tempo a empresa está no setor (qual geração da família), qual foi a trajetória da empresa até os dias atuais (mudanças, sucessos e dificuldades);

\section{Perfil da empresa}

a. Setor de atuação (produção agrícola/industrial):

b. Atividade:

c. Tipo de organização (classificação).

( ) COOPERATIVAS

Organização Privada

( ) Produtor rural PF

( ) Empresário individual

( ) Empresa Individual de Responsabilidade Limitada (EIRELI)

( )Sociedade Ltda

( ) Sociedade Anônima

( ) Outro

d. Número de colaboradores:

e. Área plantada:

f. Produção anual:

g. Culturas:

h. Possui departamento jurídico interno:

3. Análise de recursos - entender se os recursos são suficientes ou é necessário terceirizar? (Informação financeira detalhada é optativo).

a. Recursos Tangíveis

- A companhia possui seu próprio equipamento? É suficiente para as operações? (Exemplo: colhedora, plantadeira, pulverizador, caminhões, galpões, silos, etc.).

- Acesso a recursos. Para os recursos que a empresa não possui quais são as opções para acessá-los? (Aluguel, cooperativas, terceirização?).

- Limitações. Existe alguma limitação que o impede de possuir esse recurso? (Capital, financiamento, área). 
b. Recursos Humanos.

- Você julga que a equipe de colaboradores é suficiente? (Quantitativamente).

- Os colaboradores possuem todas as habilidades e conhecimento para desempenhar suas tarefas? Você contrata especialistas em alguma área de conhecimento? (Especialização).

c. Quais os recursos e capacidades são mais importantes para a empresas ter dentro de sua estrutura? Por quê?

\section{Estrutura Organizacional e Governança}

a. Estrutura organizacional (organograma, hierarquia, organização da propriedade.

b. Centro de decisão (Como e por quem são tomadas as decisões estratégicas?).

5. Rede da empresa (tipos de empresas que prestam serviços, fornecem materiais, parcerias). Checar quais atividades são integradas (estrutura organizacional), quais são contratadas e quais são compradas no mercado (rede da empresa).

ESSA PARTE É IMPORTANTE PARA COMPARAR AS ESTRUTURAS ORGANIZACIONAIS DIFERENTES EM DIFERENTES PAISES.

\section{TERCEIRIZAÇÃO}

Este bloco trata da terceirização e da opinião e estratégia da empresa em relação a atividades terceirizadas. Aqui buscamos qual o posicionamento da empresa e entender como ela toma suas decisões estratégicas em relação a subcontratação de serviços e atividades na empresa.

Este bloco exige mais detalhes que o anterior, porém ainda com respostas clara, diretas e objetivas.

6. Qual a opinião da empresa sobre a terceirização de atividades? Benefícios e prejuízos.

7. Quais são as razões, em sua opinião, do porquê empresas em geral terceirizam alguma atividade?

8. Quais são as razões, em sua opinião, do porquê empresas em geral NÃO terceirizam alguma atividade?

9. Se a sua companhia terceiriza atividades, quais as razões?

10. Há quanto tempo têm terceirizado esta atividade?

11. A atividade tem contratos formais? (Ou contratos informais com conhecidos). 
12. Quem administra os serviços terceirizados? Por exemplo, quem dá ordens aos funcionários da empresa contratada? Quem determina o modo que o serviço é realizado?

13. Quem é o RESPONSÁVEL (judicialmente se o caso virar processo judicial) pelo serviço terceirizado? (Opinião e conhecimento do dia a dia).

Exemplos:

a. Se um funcionário da empresa contratada (terceirizada) se machuca na sua propriedade, quem é responsável?

b. Se um funcionário de empresa contratada pulverize a propriedade do vizinho, quem é responsável?

c. Se a empresa terceirizada não paga a seus funcionários ou é negligente com impostos durante o período que está prestando serviços para você; quem é responsável se o caso for para a corte?

d. Se a empresa terceirizada não respeita as leis sobre tempo extra e salários mínimos, quem é responsável por isso?

14. Existem atividades que você faz atualmente que pretende terceirizar no futuro? Por que?

15. Alguma vez evitou contratar serviços terceirizados porque acreditava que poderia ser responsável judicialmente por alguma falha da empresa contratada? (Reportar quais atividades?)

16. Como acredita que a nova lei de terceirização pode alterar a situação que era imposta antes? Mais terceirização (se sim, em qual atividade?).

\section{INTERVENÇÃO JUDICIAL E IMPACTO NA EMPRESA}

Esta parte busca entender se a companhia alguma vez foi afetada por intervenções judiciais (responsabilidade judicial), como foi impactada (custos, tempo, mudanças estratégicas) e qual foram as reações estratégicas que ela adotou.

17. A empresa já sofreu ações ou intervenções judiciais?

\begin{tabular}{|l|l|l|}
\hline $\begin{array}{l}\text { Tipos de intervenções (não } \\
\text { somente ações judiciais). }\end{array}$ & SIM/ NÃO & $\begin{array}{l}\text { Mudou a estratégia da } \\
\text { empresa? Melhorou ou } \\
\text { piorou para o negócio? }\end{array}$ \\
\hline Consumidores & & \\
\hline Fiscal/ impostos & \\
\hline Ocupacional/ trabalhista \\
$\begin{array}{l}\text { Mão de obraMão de obra } \\
\text { (terceirização) - somente } \\
\text { Brasil ambiente }\end{array}$ & & \\
\hline $\begin{array}{l}\text { Meio privadas, } \\
\text { (reivindicações } \\
\text { de vizinhos ou de grupos). }\end{array}$ & & \\
\hline
\end{tabular}




\begin{tabular}{|l|l|l|}
\hline $\begin{array}{l}\text { Ações administrativas de } \\
\text { órgão governamental } \\
\text { (multas, suspensão de } \\
\text { licenças, fechamento de } \\
\text { operações). }\end{array}$ & & \\
\hline $\begin{array}{l}\text { Termos de Ajustamento de } \\
\text { Conduta (TAC) }\end{array}$ & & \\
\hline $\begin{array}{l}\text { Ações judiciais de agências } \\
\text { governamentais. }\end{array}$ & & \\
\hline Outros & & \\
\hline
\end{tabular}

* medidas administrativas, por meio de instrumentos como inquéritos civis públicos, recomendações, termos de ajustamento de conduta e audiências públicas, utilizados para coletar provas sobre a existência ou não de irregularidades.

\section{RESPONDER PRÓXIMAS SOMENTE NO CASO DE TER RELATADO ALGUMA INTERVENÇÃO JUDICIAL.}

18. Descreva as intervenções que mudaram a estratégia da empresa em relação à terceirização? (Quais foram as transações?)

19. Houve outras atividades que foram integradas verticalmente após a intervenção judicial? Descreva-os mesmo que eles não tenham sido objeto do problema.

20. Você já teve que terminar contratos assinados devido a alguma intervenção judicial?

21. A empresa já usou algum recurso de resolução de disputas em vez dos tribunais? Se sim, quais são? (Arbitragem)

\section{SISTEMA JUDICIÁRIO}

Esta parte visa compreender a percepção do entrevistado sobre o sistema judiciário no Brasil como um todo, sua operação, sua satisfação com o sistema, as leis, etc. Tudo o que você precisa fazer é marcar um valor que se aproxime da sua percepção.

22. Em sua percepção o sistema judiciário no Brasil apresenta qualidade satisfatória? (Em relação a predictabilidade, imparcialidade, e tempo de resolução).
a. Concordo plenamente.
b. Concordo.
c. Não concordo ou discordo.
d. Discordo.
e. Discordo fortemente.

23. O tempo de resolução de uma ação judicial no Brasil é.
a. Extremamente rápido.
b. Rápido.
c. Nem rápido nem muito demorado.
d. Demorado.
e. Extremamente demorado. 
24. O custo de processar ou se defender de uma ação judicial é:
a. Muito barato
b. Barato
c. Nem barato nem caro.
d. Caro
e. Muito caro.

25. A burocracia (número de procedimentos requeridos) para uma ação judicial no Brasil.
a. Não há procedimentos burocráticos.
b. Poucos procedimentos burocráticos.
c. Indeciso.
d. Alguns procedimentos burocráticos.
e. Muitos procedimentos burocráticos.

26. O acesso ao sistema judiciário do Brasil é (entrar com uma ação judicial e ir aos tribunais).
a. Muito simplificado.
b. Simplificado.
c. Nem simplificado nem complexo.
d. Complexo.
e. Muito complexo.

27. Se você contrata um serviço de uma empresa prestadora de serviços independente e esta empresa enfrenta problemas legais durante a prestação de serviços, você seria responsável por isso em tribunal?
a. Definitivamente seria corresponsável.
b. Provavelmente seria corresponsável.
c. Eu não sei.
d. Provavelmente não seria corresponsável.
e. Definitivamente não seria corresponsável.

28. Se você fosse processado judicialmente por corresponsabilidade devido ao problema de alguma empresa que te prestou serviço, você acredita que seria responsabilizado (multado, considerado culpado)?
a. Eu definitivamente seria considerado culpado.
b. Eu provavelmente seria considerado culpado.
c. Eu não sei.
d. Eu provavelmente não seria considerado culpado.
e. Eu definitivamente não seria considerado culpado.

29. Quais são as fontes de informação que você confia?
a. MAPA - Ministério de Agricultura, Pecuária e Abastecimento.
b. Extensão da ESALQ, UFSCAR, UNESP.
c. Companhias de Tradings.
d. Secretaria de Agricultura. 

e. Advogado.
f. Contador.
g. Cooperativas.
h. Outros
i. Nenhuma fonte de informação é confiável o suficiente.

30. No caso de uma disputa contratual em que você recorreria primeiro?
a. Mediação.
b. Arbitragem.
c. Sistema judiciário/ Tribunais.
d. Nenhum deles.

31. Qual é o grau de confiança que você tem em mecanismos de mediação para resolver disputas contratuais?
a. Muito baixo.
b. Moderadamente baixo.
c. Moderadamente alto.
d. Muito alto.

32. Qual é o grau de confiança que você tem em mecanismos de arbitragem para resolver disputas contratuais?
a. Muito baixo.
b. Moderadamente baixo
c. Moderadamente alto.
d. Muito alto.

33. Qual é o grau de confiança que você tem nos tribunais e juízes para resolver disputas contratuais?
a. Muito baixo.
b. Moderadamente baixo.
c. Moderadamente alto.
d. Muito alto.

34. Qual é o grau de confiança que você tem na imparcialidade dos tribunais para resolver uma disputa contratual?
a. Muito baixo.
b. Moderadamente baixo.
c. Moderadamente alto.
d. Muito alto.

35. Quanto do tempo você acha que pode confiar que os tribunais farão o que é certo?
a. Quase sempre.
b. A maior parte do tempo.
c. Apenas algumas vezes. 
APÊNDICE 3 - Intrumento de coleta de dados em Inglês

\section{English Interview script}

Information about the interviewee

\begin{tabular}{|l|l|}
\hline Name: \\
\hline Company: \\
\hline Job Title: & Contact: \\
\hline City: & State: \\
\hline
\end{tabular}

\section{Study Case Guide}

\section{COMPANY}

In this block of questions, the main characteristics of the company will be analyzed in order to compare multiple cases, as well as whether a particular feature of the company can affect the company's strategy and results.

\section{Company History}

a. How did it begin? What motivated the company/family to enter in agribusiness sector, how long the company/family has been in the sector? What has been the company's trajectory to the present day (changes, successes and difficulties)?

\section{Company Profile}

The target companies are farming operations and industries that process agricultural products

a. Activity (crop production or industrial processors):

b. Type of agribusiness organization

\section{COOPERATIVES}

PRIVATE ORGANIZATION

( ) Sole proprietor

( ) General partnership

( ) Limited Liability Company (LLC)

( ) Corporation

( ) Limited Partnership (LP)

( ) Limited Liability Partnership (LLP)

c. Number of employees:

d. Area/tonnes processed:

e. Anual production:

f. Crops:

g. Internal legal department: 
3. Resource Analysis - explore if the resources are sufficient or it's necessary to outsource? (detailed finance information is optative)

a. Tangible Resources

i. Physical Resources

- Ownership of physical structure. The company owns all its equipment? Is it enough for the operations?

- Access to resources. For the resources that the company doesn't own what are the options to access them? (rent, cooperation, outsourcing).

- Constraints. Is there any constraints that prevent you to own this resources? (capital, loan, area...)

ii. Financial Resources (balance sheet). Willingness to share the balance sheet in order to correlate performance to organizational structure - optional.

b. Human Resources

i. Is the staff sufficient (quantitatively)?

ii. Do employees have the skills and knowledge to perform their tasks? Do you contract experts in any knowledge field? (specialization)

c. What resources and capabilities are most important to the company own? Why are those so important to have inside the company? (hold up,...)

\section{Organizational Structure and Governance}

a. Organizational structure (organization chart, hierarchy, association organization). Decision center (How strategic decisions are taken?)

5. Company network (companies that provide services, inputs, or partnerships). Check which activities are, which are contracted and which are bought in the market (company network) -

THIS PART IS IMPORTANT TO COMPARE THE DIFFERENT ORGANIZATIONAL STRUCTURE IN THE DIFFERENT INSTITUTIONAL ENVIRONMENT. 


\section{OUTSOURCING}

These questions deals with outsourcing and the opinion and strategy of the company in relation to outsourced activities. Here we seek the positioning of the company about it and try to understand how the company makes its strategic decisions in relation to subcontracting activities in the company.

6. What is the company's opinion about outsourcing activities? Benefits and losses.

Explore gains from specialization and economies of scale. Better results than immobilize assets.

Explore necessity of monitoring, efficiency, loss of productivity

7. What are the reasons, in your opinion, why companies in general outsource some services?

8. What are the reasons, in your opinion, why companies in general DO NOT outsource services? (Investigate personal liability).

9. If the company outsource services, what are the reasons?

10. How long have your company outsourced this activity?

11. Does the outsourced activities have formal contracts? (Or informal, relational).

12. Who directs the services outsourced? For instance who directs the outsourced company's employees? Who directs the way (method) the services are provided (decision rights?)

13. Who is liable for the outsourced services contracted?

Examples:

e. If a contractor's employee is injured in your property are you responsible?

f. If a contractor's employee spray chemicals in the neighbor property, who is responsible?

g. If the contractor doesn't pay his employees or the taxes during the period they were providing services to you, who is responsible for it?

h. If contractor doesn't respect the laws about overtime or minimum wages who is liable for it?

14. Are there currently activities that you do yourself that you consider to outsource in the near future? Why?

15. Has the company ever refrain from contracting outsourced activities because believed that could be liable? (Report which activities).

16. How do you believe the new law could change the business environment? (only for Brazilian cases) 


\section{JUDICIAL INTERVENTION AND IMPACTS IN COMPANY}

This part aims to understand if the company has already been affected by judicial interventions (liability) from legal environment, how it was impacted (costs, time, strategic changes) and what strategic reactions it has adopted to these interventions.

17. Has the company ever suffered legal action or judicial intervene? What were the ones that the company most suffered in the last 5 years? Survey

\begin{tabular}{|l|l|l|}
\hline $\begin{array}{l}\text { Intervention type (not only } \\
\text { lawsuits). }\end{array}$ & YES/NO & $\begin{array}{l}\text { Changed the company } \\
\text { strategy? Better or } \\
\text { worse? }\end{array}$ \\
\hline Customers & & \\
\hline Fiscal/taxes & & \\
\hline Occupational/labor & \\
\hline $\begin{array}{l}\text { Labor (outsorcing) - Brazil } \\
\text { only }\end{array}$ & \\
\hline $\begin{array}{l}\text { Environment nrivate } \\
\text { clains from neighbor or } \\
\text { groups). }\end{array}$ & \\
\hline $\begin{array}{l}\text { Administration action from } \\
\text { Government agencies } \\
\text { (fines, hold permit, close } \\
\text { operations). }\end{array}$ & \\
\hline $\begin{array}{l}\text { Judicial lawsuits from } \\
\text { Government agencies. }\end{array}$ & & \\
\hline \begin{tabular}{l} 
Others \\
\hline
\end{tabular} & \\
\hline
\end{tabular}

\section{JUST IN CASE OF LEGAL INTERVENTIONS}

18. Describe the interventions that changed the company's strategy regarding outsourcing? (What were the transactions? Verify asset specificity, specialization, capital immobilization and necessary investments).

19. Were there other activities that has been vertically integrated after the judicial intervention? Describe them even if they weren't object of the problem.

20. Have you ever had to end contracts signed due to some judicial intervention?

21. Has the company ever used other dispute resolution resource instead of the courts? If so, which ones? (Arbitration) 


\section{JUDICIAL SYSTEM IN UNITED STATES OF AMERICA}

This part aims understanding the perception of respondent about the judicial system in United States as a whole, its operation, his satisfaction with the system, the laws, etc. All you need to do is mark a value that comes close to your perception.

22. In your perception does the judicial system in USA presents satisfactory quality (predictability, unbiased, time).

f. Strongly agree

g. Agree

h. Doesn't agree or disagree (Undecided)

i. Disagree

j. Strongly disagree

23. The time for resolving lawsuits in USA are.

f. Extremely fast.

g. Fast

h. Nor fast or time consuming.

i. Time consuming.

j. Extremely time consuming.

24. The cost to sue or defend against a lawsuit.
a. Very Inexpensive
b. Inexpensive
c. Nor inexpensive or expensive
d. Expensive
e. Very expensive

25. The bureaucracy (number of procedures) required for a lawsuit in USA.
a. There are not bureaucratic procedures
b. Few bureaucratic procedures
c. Undecided
d. Some bureaucratic procedures
e. Many bureaucratic procedures.

26. The access to the USA legal system (file a lawsuit and go to courts).
a. Very simplified
b. Simplified
c. Nor simplified or complex
d. Complex
e. Very complex 
27. If you contract a service from a independent contractor and this company faces legal problems while providing services would you be liable for it in court?
a. Definitly liable
b. Liable
c. I dont know
d. Not liable
e. Definitly not liable

28. If you were sued for personal liability due to some contractor's problem do you believe you would be convicted (liable)?
a. I definitly would be convicted
b. I would be convicted
c. I don't know
d. I would not be convicted
e. I definitly would not be convicted.

29. What are the sources of information about outsourcing services do you trust?
a. USDA
b. MU extension
c. Commodity companies
d. Farm bureau
e. Lawyer
f. Accountant
g. Cooperatives
h. Others
i. None of them

30. In the case of a contract dispute wich mechanism would you rely first?
a. Mediation
b. Arbitration
c. Courts
d. None of them

31. What is de degree of trust do you have in mediation to solve a contract dispute?
a. Very low
b. Moderately low
c. Moderately high
d. Very High

32. What is de degree of trust do you have in arbitration to solve a contract dispute?
a. Very low
b. Moderately low
c. Moderately high
d. Very High 
33. What is de degree of trust do you have in courts to solve a contract dispute?
a. Very low
b. Moderately low
c. Moderately high
d. Very High

34. What is de degree of trust do you have in the unbiasedness of the courts to solve a contract dispute?
a. Very low
b. Moderately low
c. Moderately high
d. Very High

35. How much of the time do you think you can trust the courts will do what is right.
a. Just about always
b. Most of the time
c. Only some of the time 
APÊNDICE 4 - Carta de agradecimento aos entrevistados

(papel timbrado da universidade)

Ribeirão Preto, $X X$ de $X X X$ de $20 X X$.

À propriedade rural

A/C. nome do contato indicado

Vimos, por meio desta, agradecer sua participação no estudo de caso referente à pesquisa de Doutorado Interferências do ambiente institucional nas estruturas de governança de cadeias do agronegócio., realizada pela aluna Ana Luiza Camargo Mascarin, sob orientação do Prof. Dr. Marcos Fava Neves, do Departamento de Administração, da Faculdade de Economia, Administração e Contabilidade de Ribeirão Preto, da Universidade de São Paulo.

Agradecemos pela colaboração com o desenvolvimento desse trabalho.

Lembramos que lhe será enviado um exemplar digital dessa Tese depois de finalizada toda a pesquisa.

Agradecemos a sua colaboração.

Atenciosamente,

Pesquisadora: Ana Luiza Camargo Mascarin (ana.mascarin@usp.br)
Prof. Dr. Marcos Fava Neves

(favaneves@usp.br) 